\title{
"Busy Mischievous Ffellows": Imperial Agency in Pennsylvania During the Seven Years' War
}

\author{
Benjamin G. Scharff
}

Follow this and additional works at: https://researchrepository.wvu.edu/etd

\section{Recommended Citation}

Scharff, Benjamin G., "'Busy Mischievous Ffellows": Imperial Agency in Pennsylvania During the Seven Years' War" (2014). Graduate Theses, Dissertations, and Problem Reports. 6578.

https://researchrepository.wvu.edu/etd/6578

This Dissertation is protected by copyright and/or related rights. It has been brought to you by the The Research Repository @ WVU with permission from the rights-holder(s). You are free to use this Dissertation in any way that is permitted by the copyright and related rights legislation that applies to your use. For other uses you must obtain permission from the rights-holder(s) directly, unless additional rights are indicated by a Creative Commons license in the record and/ or on the work itself. This Dissertation has been accepted for inclusion in WVU Graduate Theses, Dissertations, and Problem Reports collection by an authorized administrator of The Research Repository @ WVU.

For more information, please contact researchrepository@mail.wvu.edu. 
“Busy Mischievous Ffellows": Imperial Agency in Pennsylvania During the Seven Years' War

Benjamin G. Scharff

Dissertation Submitted to the Eberly College of Arts and Sciences at West Virginia University in partial fulfillment of the requirements for the degree of

Doctor of Philosophy in History

Tyler Boulware, Ph.D., Chair

Joseph Hodge, Ph.D

Brian Luskey, Ph.D.

Kenneth Fones-Wolf, Ph.D

Daniel Barr, Ph.D., Robert Morris University

Department of History

Morgantown, West Virginia

2014

Keywords: Pennsylvania, Seven Years' War, authority

Copyright 2014 Benjamin G. Scharff 


\begin{abstract}
“Busy Mischievous Ffellows": Imperial Agency in Pennsylvania During the Seven Years' War
\end{abstract}

Benjamin G. Scharff

This project explores British colonial interaction with imperial authority in mid-eighteenth century Pennsylvania. The goal is to show that reactions to this authority proved much more complicated than previously identified. This has been done by examining the personal interactions of Pennsylvanians with Britons in political, economic, diplomatic and inter-colonial affairs. Upon examination of these exchanges, it becomes clear that Pennsylvanians differed greatly in their support of British authority depending on their personal place in society and the particular issues they were most personally connected to. By demonstrating the variety of reactions, this research highlights the importance of studying colonial opposition to Great Britain on a local level. 


\section{ACKNOWLEDGEMENTS}

Many people are deserving of thanks for assisting me in the completion of my work. First, several of my fellow students-Isaac Emrick, Kat Fichtel, Laura Nelson, Jason Roberts, and Alec Upward-pushed me to improve during my time at West Virginia University. A special thanks is merited by Kat and Alec, along with my brother Pete Scharff, for sacrificing their time in reading dissertation chapters and providing me with invaluable comments. The faculty and staff at the history department at West Virginia were likewise extremely supportive throughout the course of my time at the university. The secretaries, Martha May and Becky Warnke, adeptly helped guide me through the program while the department chair, Elizabeth Fones-Wolf, offered consistent support. My committee, consisting of Ken Fones-Wolf, Brian Luskey, Joseph Hodge, and Tyler Boulware, shared their knowledge and provided excellent direction. A special thank you is merited by Tyler who served as my principal advisor and as such worked with me more minutely throughout the process.

I would remiss if I did not recognize those outside the program who provided immeasurable sources of support. John Craig at Slippery Rock University, Kevin Kopper at Westmoreland County Community College, and Kathy Dennick-Brecht and Dan Barr at Robert Morris University each provided me with professional opportunities at their institution which have proven invaluable to my success. Dan additionally agreed to serve as my outside committee reader. Professionals at the David Library of the Revolution, Historical Society of Pennsylvania, British Library, Scottish National Archives, and Bodleian Library assisted me greatly in acquiring the research materials necessary to complete my project. My research additionally benefitted greatly from the lengthened time I was able to spend in London with the convenient lodging provided by childhood friend David Antoline and his very patient wife Katie.

Finally, I would not have been successful without the unwavering support of my family. My father and brothers Pete, Andy, and Jon were consistent sources of motivation and encouragement. 
Their support pales only in comparison to that supported by Shasta. I look forward immensely to show her what a life without a dissertation is like. 


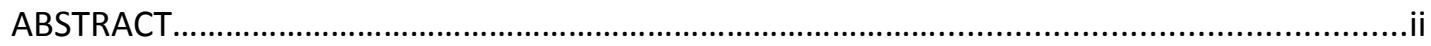

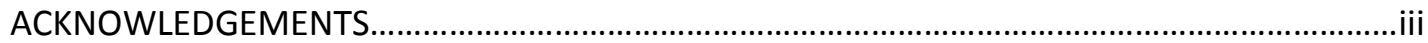

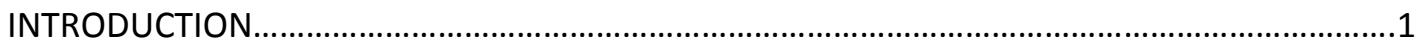

CHAPTER 1. Pennsylvania Provincial Politics.........................................................................2

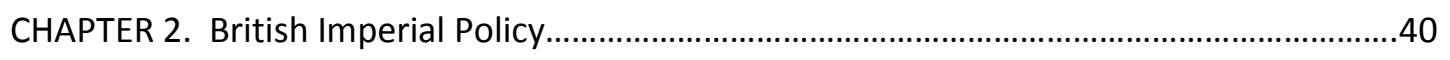

CHAPTER 3. The British Military and Provincial Authority.......................................................90

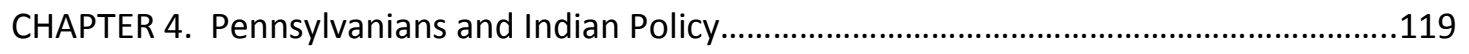

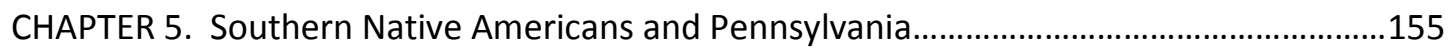

CHAPTER 6. British Agents and Colonial Competition....................................................189

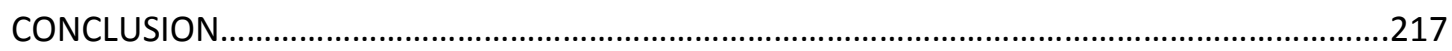

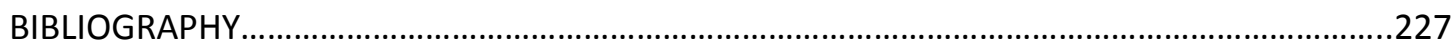




\section{$\underline{\text { Introduction }}$}

On November 27, 1758, General John Forbes reported from the smoldering remains of Fort Duquesne that he had successfully ousted the French from their position controlling the contested Ohio Country region. Longstanding competition between the French and British for the strategic and lucrative territory had prompted the French to move military forces in to secure its control in 1754, which led the British to respond in turn. The resulting conflict, the Seven Years' War, engulfed four continents and engaged numerous combatants.

The war proceeded poorly for Great Britain in North America from the outset. Stunned by a series of significant defeats and paralyzed by lighting raids by France's Canadian and Native American allies, Britain faced almost certain defeat until the tide began to turn in 1758 when significant support began to arrive under the direction of Secretary of State William Pitt. Pitt proposed a three-pronged attack that year that proved too overwhelming to be countered by the French.

The Secretary entrusted the southernmost offensive to Forbes, an officer who had spent the majority of his career arranging the supply and maintenance of armies rather than commanding them in the field. He proved an excellent choice. Moving his headquarters to Philadelphia and opting for an attack on the French position in the Ohio Country where the conflict had begun, Forbes successfully harnessed the strength of the southern colonies, binding them to the British military, and drove the French out of the contested territory.

Militarily, the French posed little threat to Forbes's advance. The French possessed several hundred troops and an unstipulated, but certainly not overwhelming, amount of Canadians and Native Americans to combat the nearly eight thousand men under Forbes's command. The general's primary challenge resulted from the wide assortment of soldiers comprising his army-Scottish Highlanders, Germans, Pennsylvanians, Marylanders, Virginians, North Carolinians, Cherokee \& Catawba among 
others - and the corresponding squabbles that existed amongst some of these entities. Here Forbes's administrative talents served him well.

Navigating a labyrinth of issues within colonies, between colonies, and amongst Britain's Native American allies, the general managed to secure the necessary support to keep his army in the field long enough to compel the French to abandon their position. Generating this necessary support from the provinces did not proceed as smoothly as British authorities might have thought because many of the colonists negotiated their interactions with Forbes and his officers rather than responding with unquestioning compliance. The general's close interaction with various entities in North America thus proves an instructive arena to examine the nature of colonial views of their relationship with Great Britain in the mid-eighteenth century.

Upon first arriving in North America in 1756, Forbes's second-in-command, Colonel Henry Bouquet of the Royal American Regiment, reported that "while entering the city on horseback at the head of the battalion a farmer rogue mounted on a nag lashed at me with his whip.." ${ }^{1}$ This had been, the colonel further noted, the third episode of its kind. Bouquet's negative interaction with a colonist colorfully mirrors other clashes that occurred between British military authorities and colonists throughout the colonial period. His report about colonial hostility has thus become, in part, the basis for a conveniently simplistic narrative about the decline of the relationship between the British and their North American colonists in the third quarter of the eighteenth century.

According to this narrative, the relationship between Britain's North American colonies and the imperial metropole of London developed into a system of "benign neglect" where the provinces adopted an extensive sense of independence in the seventeenth and first half of the eighteenth century. The earliest and most traditional discussions of the relationship helped lay the foundations for such a

\footnotetext{
${ }^{1}$ Henry Bouquet to John Young, December 15, 1756 in S.K. Stevens, Donald H. Kent, and Autumn L. Leonard eds., The Papers of Henry Bouquet: The Forbes Expedition (hereafter BP), 6 Vols. (Harrisburg, PA: The Pennsylvania Historical and Museum Commission, 1951), I:37.
} 
viewpoint. By focusing almost exclusively on decisions and policies originating from the metropole, these works necessarily highlighted the relative inactivity of policy-makers in colonial affairs, leading to the dominating concept of the empire as one of "benign neglect." Others have built upon this concept by compiling encounters similar to that experienced by Bouquet to demonstrate the deep-seated hostility that developed between colonists and military personnel when they began to reverse this preexisting policy. ${ }^{2}$

The strenuous study of demographic data inaugurated by the advent of Atlantic history has diminished this metrocentric viewpoint and instead demonstrated a sustained system of interconnections between colonies and mother country during this so-called period of "benign neglect." Historians have stressed a deep intellectual connection between the two peoples suggesting the existence of a British Atlantic political community. While this transition away from the policies of authorities in London in favor of the agency of the colonists undoubtedly changed the focus of scholarship and led to differing conclusions about the interconnectedness of communities on opposing sides of the Atlantic, they failed to offer an appreciably more detailed explanation for colonial hostility towards British military authorities. Although earlier historians would explain the farmer's attack on Bouquet as a result of the military's presence overturning more than a century of independence, newer interpretations indicate that this farmer possessed a deep intellectual antipathy to standing armies that manifested itself upon encountering the military. ${ }^{3}$

Recent global and borderland histories, however, have added detail to our understanding of Anglo- American relationships in the years preceding the American Revolution. Relatively recent works

${ }^{2}$ Charles M. Andrews, The Colonial Background of the American Revolution (New Haven, CT: Yale University Press, 1924); Charles M. Andrews, The Colonial Period of American History, 3 Vols. (New Haven, CT: Yale University Press, 1935); Lawrence Henry Gipson, The British Empire Before the American Revolution (New York: Knopf Publishing, 1958); Douglas Edward Leach, Roots of Conflict: British Armed Forces and Colonial Americans, 1677-1763 (Chapel Hill, NC: The University of North Carolina Press, 1986).

${ }^{3}$ Bernard Bailyn, The Ideological Origins of the American Revolution (Cambridge, MA: The Belknap Press of the Harvard University Press, 1967); Alison Gilbert Olsen, Making the Empire Work: London and American Interest Groups, 1690-1790 (Cambridge, MA: Harvard University Press, 1992). 
have applied concepts of indirect and direct rule, typically reserved for discussions of indigenous populations in Britain's later Asiatic and African empires, to the settler communities in North America. In each case, the authors suggest that the relationship became strained as imperial policy drove a wedge between the associated peoples by undercutting the indirect nature of the British Empire prior to the 1750s. Eric Hinderaker, for example, contends that imperial policy became difficult if not impossible to implement in North America's hinterlands because the colonists had previously developed a modicum of negotiated authority. He also suggests that the region proved simply too large to control from centers of imperial power. P.J. Marshall builds upon this premise, arguing that the British failed to recognize these realities and attempted to import more direct forms of rule from their newly won possessions in India to the New World after the Seven Years' War. ${ }^{4}$

Regardless of the perspective towards colonial agency, the historiography suggests that the Seven Years' War, and the resultant metropolitan shift in policy, profoundly affected the relationship between North America and Britain. This assessment exists for good reason. The Seven Years' War assumed vast importance in redefining the relationship between Great Britain and its colonies because of its scale. It not only reached mammoth proportions in Europe and stretched across most of the globe, but it likewise demanded the first major British military commitment in North America and ultimately mobilized the colonial societies beyond anything previously seen. The enlarged and diversified empire Britain found itself in possession of at the end of the conflict, moreover, ensured that this event elicited some type of significant change. Because so much focus has been placed on British imperial policy, the individuals engaged in the highest levels of government have received much attention.

${ }^{4}$ Eric Hinderaker, Elusive Empires: Constructing Colonialism in the Ohio Valley, 1673-1800 (New York: Cambridge University Press, 1997); P.J. Marshall, The Making and Unmaking of Empires: Britain, India, and America, c. 1750-1783 (New York: Oxford University Press, 2005). 
Interpretations of British imperial policy during the Seven Years' War has predominantly revolved around the activities and decisions of William Pitt, Secretary of State of the Southern Department from 1757 through 1760. The discussion of this dynamic individual has shifted in roughly chronological order. The oldest works portray the secretary as a dominant minister. Revisionist historians, on the other hand, relegate Pitt to a figure whose influence has been exaggerated. Others have complicated this discussion by demonstrating the degree to which Pitt and other prominent ministers in the cabinet collaborated. The individual interests and goals of these figures becomes of paramount importance because their policies helped to define the relationship between colonists and the empire during the Seven Years' War. ${ }^{5}$

The historiography thus emphasizes that changing policies resulted in the straining of Great Britain's relationship with its North American colonies but this connection between the Seven Years' War and the emergence of opposition to British policy has only been established with the broadest of strokes. Fred Anderson attempts to update the interpretation by identifying the deep sense of disappointment colonists felt about their role in the empire after the successful completion of the conflict. Although they had been imbued with pride in their connection to the British Empire after victory, that very pride had augmented the extent to which they felt disappointment at the realities they then faced in the decades after the conflict. New Englanders, for example, built a semblance of a cult of personality around the martyred General Wolfe while simultaneously resisting British imperial directives beginning in the 1760s. Anderson's assessment is on point, but he too paints with a rather broad stroke by attempting to explain a mentality possessed by colonists in thirteen very diverse provinces. Much of

\footnotetext{
${ }^{5}$ Walford Davis Green, William Pitt, Earl of Chatham, and the Growth and Division of the British Empire, 1708-1778 (New York: G.P. Putnam's Sons, 1901); Jeremy Black, Pitt the Elder (New York: Cambridge University Press, 1992); Richard Middleton, The Bells of Victory: The Pitt-Newcastle Ministry and the Conduct of the Seven Years' War, 1757-1762 (New York: Cambridge University Press, 1985); Marie Peters, Pitt and Popularity: The Patriot Minister and London Opinion during the Seven Years' War (Oxford: Clarendon Press, 1980); Basil Williams, The Life of William Pitt, Earl of Chatham (New York: Octagon Books, Inc., 1966); O.A. Sherrard, Lord Chatham: Pitt and the Seven Years' War (London: The Garden City Press Limited, 1955).
} 
the author's evidence also derives almost exclusively from New England sources. What is necessary is a detailed case study of one colony, particularly beyond New England, to evaluate these rather broad assertions. $^{6}$

Scholarship on Pennsylvania in the Seven Years' War lags behind that of regions such as New England. Few direct and specific studies have focused on Pennsylvania. More often, the events of 1758 appear in broader, but more general works where they represent an important thread in the discussion. Francis Jennings, for example, produced a vast reinterpretation of the Seven Years' War. Instead of focusing on the chronology, Jennings addresses the conflict topically. He does examine imperial authority in conjunction with Pennsylvanian Quaker interests in controlling Native American diplomacy. Jennings accurately indicates that both entities concurrently attempted to assert its authority over diplomacy. James $\mathrm{H}$. Merrell likewise associates civilian and imperial military efforts to collaborate in Native American diplomacy by discussing at length the efforts at Easton in the fall of 1758 . While offering a sweeping description of Benjamin Franklin's life, Walter Isaacson addresses colonial interaction with imperial authorities. Contrary to the consensus interpretation, however, Isaacson depicts Franklin as a dexterous politician whose fervent opposition to the colony's proprietors leads him to conclude that Pennsylvania would benefit from a greater association with imperial authority during the Seven Years' War and the immediately subsequent years, not less. ${ }^{7}$

\footnotetext{
${ }^{6}$ Fred Anderson, Crucible of War: The Seven Years' War and the Fate of Empire in British North America, 1754-1766 (New York: Vintage Books, 2000).

${ }^{7}$ For specific treatments of Pennsylvania, see Alfred Proctor James and Charles Morse Stotz, Drums in the Forest: Decision at the Forks, Defense in the Wilderness (Pittsburgh: Historical Society of Western Pennsylvania, 1958); Niles Anderson, "New Light on the Forbes Expedition," The Western Pennsylvania Historical Magazine, Vol. 50, No. 2 (April 1967); Doug Cubbison, The British Defeat of the French in Pennsylvania, 1758: A Military History of the Forbes Campaign Against Fort Duquesne (Jefferson, NC: McFarland, 2010); David L. Preston, "“Make Indians of our White Men": British Soldiers and Indian Warriors from Braddock's to Forbes's Campaigns, 1755-1758," Pennsylvania History, Vol. 74, No. 3 (Summer 2007); R.S. Stephenson, "Pennsylvania Provincial Soldiers in the Seven Years' War," Pennsylvania History, Vol. 62, No. 2 (Spring, 1995); Matthew C. Ward, "An Army of Servants: The Pennsylvania Regiment During the Seven Years' War," The Pennsylvania Magazine of History and Biography,
} 
Anderson and Matthew C. Ward most directly address the subject of the conflict and imperial authority in Pennsylvania. While Pennsylvania remains a veritable sideshow to New York and New England to Anderson, the magnitude of the work necessarily includes the Quaker colony and the broader conclusions drawn by the author, though largely derived from the New England experience, are applied to the colonies as a whole. Anderson contends that the Seven Years' War sowed the seeds for opposition to Great Britain precisely as a result of the close interaction between imperial entities and colonists. While colonists proved remarkably committed to the empire after victory in 1760 , their personal experiences and later British policies made them question this relationship. The very commitment and pride in empire, in Anderson's view, ultimately led to opposition because the colonists acquired a deep sense of disappointment at how events transpired after possessing such high expectations for the new empire. ${ }^{8}$ Ward concurs, arguing that "[c]olonists witnessed firsthand the ineptitude of British commanders. The wartime experience of the colonies was to prove central in convincing Virginia and Pennsylvania of their ability to resist British power. Without such confidence the political crisis of the 1760 s and 1770 s might have taken a rather different turn in this region." ${ }^{9}$ Ward's $^{\prime}$ argument specifically builds upon a popular image of the British officers as blundering idiots unable to cope with the unique conditions of fighting a conflict in North America and too arrogant to seek or take the advice of more knowledgeable locals. Detailed study of Forbes and Bouquet, the principal British military figures in Pennsylvania, reveals an entirely differing view of their ineptitude and unwillingness

Vol. 119, No. 1/2 (January-April 1995). These works overwhelming deal with military facets of the Seven Years' War and do not analyze Pennsylvania's relationship with the empire. For broader discussions of the era see Francis Jennings, Empire of Fortune: Crowns, Colonies, and Tribes in the Seven Years War in America (New York: W.W. Norton \& Company, 1990); Gipson, British Empire; James H. Merrell, Into the American Woods: Negotiators on the Pennsylvania Frontier (New York: W.W. Norton \& Company, 1999); Walter Isaacson, Benjamin Franklin: An American Life (New York: Simon \& Schuster, 2003).

${ }^{8}$ Anderson, Crucible of War; Matthew C. Ward, Breaking the Backcountry: The Seven Years' War in Virginia and Pennsylvania, 1754-1765 (Pittsburgh: University of Pittsburgh Press, 2003).

${ }^{9}$ Ward, Breaking the Backcountry, 3. 
to adapt to the environment and conditions within which they operated. Thus, both the works of Anderson and Ward correctly envision the Seven Years' War as a transformative event in the evolution of Britain's relationship with its colonies, but they remain tied to the original premise that the colonists became disenchanted with the metropole because of their negative interactions with an ignorant and arrogant military establishment.

In the last decade, historians have focused on extending this examination of Pennsylvania into the bloody and chaotic 1760 s. While imperial policy, such as the Proclamation of 1763 , does create unrest, the favorable treatment of British officials towards Native Americans in Pennsylvania proved critical as well. Historians have also closely connected the experience of the Seven Years' War with serious conflicts at the local level within Pennsylvania during and shortly after the conflict. These studies of Pennsylvania in 1760 prove immensely instructive for understanding the source of friction between the province and Great Britain. Each demonstrates the extent to which local conflicts existed concurrently in Pennsylvania with the more popularized antagonism against British imperial policy. An image of an unstable colony, wracked by internal political quarrels and serious disagreements about how relations with Native Americans should be conducted thus emerges. More recent work further demonstrates the extent to which Pennsylvania found itself locked in serious territorial competition with Virginia in the 1760 s and beyond. Thus, if the Seven Years' War strained the relationship between the colonies and Great Britain, it also appears to have exacerbated pre-existing colonial issues. ${ }^{10}$ Pennsylvania thus proves ideally situated to conduct just such a case study. The proprietary nature of Penn's colony had traditionally made it even more difficult for imperial authorities to

\footnotetext{
${ }^{10}$ David Dixon, Never Come to Peace Again: Pontiac's Uprising and the Fate of the British Empire in North America (Norman, OK: University of Oklahoma Press, 2005); Matthew C. Ward, "The Peaceable Kingdom Destroyed: The Seven Years' War and the Transformation of the Pennsylvania Backcountry," Pennsylvania History, 74 (Summer 2007); Kevin Kenny, Peaceable Kingdom Lost: The Paxton Boys and the Destruction of William Penn's Holy Experiment (New York: Oxford University Press, 2009); Daniel Barr, A Colony Sprung from Hell: Pittsburgh and the Struggle for Authority on the Western Pennsylvania Frontier, 1744-1794 (Kent, OH: Kent State University Press, 2014).
} 
intervene in its affairs. The Board of Trade, for example, found itself unsure about its authority to dictate to the Quaker colony. As a consequence, if a state of "benign neglect" existed in the North American colonies, the rights of Pennsylvania's proprietors ensured that this neglect existed to a greater degree in Pennsylvania than in other royal colonies. Consequently, the shift to more direct forms of rule after the Seven Years' War should have more starkly affected Pennsylvanian than its neighbors.

In the colonial period, moreover, Pennsylvania is routinely portrayed as a model of diversity, tolerance, and prosperity. The colony from its inception became a popular destination for immigration from the British Isles and the Germanic states. While harmony largely existed in William Penn's socalled "Peaceable Kingdom" under the domineering Quaker interests, it has been conclusively demonstrated that this harmony declined precipitously by the mid-eighteenth century. The unsettled nature of internal politics, the changing relationship with Native Americans, and continued competition with colonial neighbors in mid-century makes Pennsylvania an excellent backdrop from which to study the effects of British authority intervening in these affairs. ${ }^{11}$

${ }^{11}$ John K. Alexander, "Deference in Colonial Pennsylvania and That Man from New Jersey," The Pennsylvania Magazine of History and Biography, Vol. 102, No. 4 (October, 1978); Benjamin Bankhurst, "A Looking-Glass for Presbyterians: Recasting a Prejudice in Late Colonial Pennsylvania," The Pennsylvania Magazine of History and Biography, Vol. 133, No. 4 (October, 2009); Laura L. Becker, "The People and the System Legal in a Colonial Pennsylvania Town," The Pennsylvania Magazine of History and Biography, Vol. 105, No. 2 (April, 1981); William L. Fisk Jr., "The Diary of John Cuthbertson, Missionary to the Covenanters of Colonial Pennsylvania," The Pennsylvania Magazine of History and Biography, Vol. 73, No. 4 (Oct. 1949); Mark Häberlein, "German Migrants in Colonial Pennsylvania: Resources, Opportunities, and Experience," The William and Mary Quarterly, Third Series, Vol. 50, No. 3 (July, 1993); Daniel Johnson, “'What Must Poor People Do?': Economic Protest and Plebeian Culture in Philadelphia, 1682-1754," Pennsylvania History: A Journal of Mid-Atlantic Studies, Vol. 79, No. 2 (Spring 2012); Michael B. McCoy, "Barbarian Philosophe: Market, Modernity, and the Enlightenment on James Smith's Frontier," Pennsylvania History. Vol. 76. No.3 (Summer, 2009); Sally Schwartz, "A Mixed Multitude": The Struggle for Toleration in Colonial Pennsylvania (New York: New York University Press, 1987); Lucy Simler, "Tenancy in Colonial Pennsylvania: The Case of Chester County," The William and Mary Quarterly, Third Series, Vol. 43, No. 4 (October 1986); Alan Tully, "Englishmen and Germans: National-Group Contact in Colonial Pennsylvania, 1700-1755," Pennsylvania History, Vol. 45, No. 3 (July, 1978); Hermann Wellenreuther, "The Quest for Harmony in a Turbulent World: The Principle of "Love and Unity" in Colonial Pennsylvania Politics," The Pennsy/vania Magazine of History and Biography, Vol. 107, No. 4 (October 1983); Thomas Wendel, "The Keith- 
The colony's reputation as the "Peaceable Kingdom" came to a definitive end in the mid-1750s as the colony mobilized for the first time in its seventy year history. The province also experienced an influx of British military authorities in 1758 with the arrival of General John Forbes and thousands of British regular troops and officers. The ensuing campaign represented the first of its kind in Pennsylvania and the relative briefness of its execution provides a well-defined arena within which to explore colonial interactions with imperial authorities.

Almost overnight, Pennsylvania became an armed camp with effects that touched nearly the entirety of the province's population. On April 21, 1758, the main British force to serve under Forbes arrived in Philadelphia. By all accounts, it was a "spectacular sight."12 As the transports drifted up the Delaware River, the significance of the event was not lost on the residents of British North America's largest urban center. As James Burd, a leading Pennsylvanian officer, noted, "Every Body [italics mine] is Preparing for [the] Expedition."13 Indeed they were. At the outbreak of war in 1755, the woefully unprepared colony had relied upon volunteer militiamen called Associators. By 1758, however, Pennsylvania had mobilized its entire adult male population into militias. Required to arm themselves and muster periodically, many Pennsylvanians played important local roles during Forbes's march to the Ohio. ${ }^{14}$

Yet the campaign also inextricably involved the civilian population. As the campaign moved slowly westward, communication between soldiers and families near the eastern staging areas

Lloyd Alliance: Factional and Coalitin Politics in Colonial Pennsylvania," The Pennsy/vania Magazine of History and Biography, Vol. 92, No. 3 (July 1968).

${ }^{12}$ Peter Bard to Joseph Shippen, April 22, 1758 in The Shippen Family Papers, Historical Society of Pennsylvania (hereafter HSP), Philadelphia.

${ }_{13}$ James Burd to Edward Shippen Sr., May 8, 1758 in ibid.

${ }^{14}$ See Samuel J. Newland, The Pennsylvania Militia: The Early Years, 1669-1792 (Annville, PA: Commonwealth of Pennsylvania Department of Military and Veterans Affairs, 1997) for a thorough discussion of the colony's militia. The Second Militia Act is first listed in The Pennsylvania Gazette, May 13, 1756. 
remained possible. As a result, news, well wishes, and gifts traveled back and forth across the colony. ${ }^{15}$ Civilians, then, did not impassively await news of a far-away army, but instead remained connected on an intimate basis. Although largely insulated from the conflict's violence directly, easterners read lurid accounts of Indian attacks in the colony's newspapers. In the aftermath of victory, the civilian population remained involved directly as it dealt with the human consequences of warfare. Veterans returned home and orphans of the men who would never return needed caring for. Thousands of settlers had abandoned their improved lands along the borders of Pennsylvania's settlements and thousands more had been killed or captured by French-allied natives. In later years, captives taken by Indian enemies during the campaign began returning to Pennsylvania. ${ }^{16}$ This widespread involvement ensured that much of the colonial population had some intimate association with the campaign, and it affected them in subsequent years.

The prevalence of the conflict in the lives of Pennsylvania did, however, provide immediate financial rewards for many. Both indirect and direct economic involvement with the provincial and British militaries should have served as a stabilizing factor for Pennsylvania's battered economy. The influx of British troops and the increase of locally raised soldiers had by 1758 begun to overturn the colony's recent economic woes. Harassed by French privateers, merchants found their insurance rates

\footnotetext{
${ }^{15}$ See letters between Joseph Shippen and his family April 25, 1758, April 30, 1758 and August 15, 1758 and James Burd and his wife October 14, 1758 in Shippen Papers, HSP.

${ }^{16}$ Peter Silver discusses the newspaper accounts in Our Savage Neighbors: How Indian War Transformed Early America (New York: W.W. Norton and Company, 2008). For an account of orphans, see Will Allen to John Knowles, September 22, 1764 in Chester County Papers, Historical Society of Pennsylvania, Philadelphia. The letter refers to 1758. For an account of captives who returned in 1759, see "Narrative of Marie Le Roy and Barbara Leininger" in John W. Harpster ed., Crossroads: Descriptions of Pennsylvania, 1720-1829, 52-59. For an account of a captive taken during the expedition see lan McCulloch and Timothy Todish eds., Through So Many Dangers: The Memoirs and Adventures of Robert Kirk, Late of the Royal Highland Regiment (Fleischmans, NY: Purple Mountain Press, 2004). Matthew Ward tabulates those killed and captured by the Indians in "La Guerre Sauvage": The Seven Years' War on the Virginia and Pennsylvania Frontier (Unpublished PhD Dissertation: College of William and Mary, 1992).
} 
had increased substantially during the early years of the war. More troublesome, Britain's trade embargo, meant to ensure that its enemies did not benefit from trade with the colonies, had crippled the grain trade. Faced with limited markets, Pennsylvania grain traders and farmers either smuggled or struggled to find legal markets. These economic woes began to change with the passage of the Troop Bill in the Pennsylvania Assembly on April 23, 1758. Authorized to raise a force of 2500 men, the relatively high pay and lucrative signing bonus (called a bounty) immediately attracted the most economically downtrodden Pennsylvanians. In fact, so many indentured or formerly indentured servants entered the service that one historian described the Pennsylvania troops as an "army of servants." For those unwilling to serve in a military capacity, the army offered opportunities for craftsmen to ply their trades. Carpenters, saddlers, wheelwrights, collar makers, artificers, bricklayers, brickmakers, foragers, and wagoners all found that demand for their skills was high in the newly militarized countryside. Merchants and clothiers likewise benefited from the new demands inherent in the raising of such a large force, as individual officers combed the colony in an attempt to outfit their new recruits. ${ }^{17}$

The arrival of General Forbes and his British troops, however, far outstripped the economic advantages created by the emergence of the Pennsylvanian battalions. Along with the King's troops came the King's gold, and Forbes, liberally financed by orders from William Pitt, flooded the Pennsylvania economy with cash and credit. Colonists rushed to partake in the trade, supplying amenities from fruit beverages to alcohol. On a more practical level, foodstuffs and animal forage

\footnotetext{
${ }^{17}$ Pennsylvania's economic woes are discussed in Ward, Breaking the Backcountry, 72-73. The troop bill and recruiting is highlighted in Edward Shippen to James Burd, April 30, 1758 in Shippen Papers, HSP. The composition of Pennsylvania's recruits is examined in Ward, Breaking the Backcountry, 99; R.S. Stephenson, "Pennsylvania Provincial Soldiers in the Seven Years' War," Pennsylvania History, 196-198; and Matthew C. Ward, "An Army of Servants: The Pennsylvania Regiment during the Seven Years' War," The Pennsylvania Magazine of History \& Biography CXIV, no. $1 / 2$ (January/April 1995): 76. The use of tradesmen is highlighted, among many other places, in Louis Ourry to Henry Bouquet, 24 May 1759, in Stevens BP, 3:35. An account of the outfitting of troops is contained in Joseph Shippen to James Burd, May 3, 1758, in Shippen Papers, HSP.
} 
became critical demands for the military, thus creating overnight a new market for Pennsylvania farmers feeling the pinch after Britain enacted the trade embargo.

The economic benefits offered by the arrival of the British military should have assisted in solidifying firm Anglo-American relations in the late 1750 s and early 1760 s. Instead, antagonism built in the 1760s leading to the conclusion that colonists had rankled under the more direct supervision of British agents. Despite the generic portrayal of British officers as ignorant and arrogant, however, those who found success in North America adeptly and effectively engaged colonials in a positive fashion. Forbes and his subordinates became remarkably active in Pennsylvanian affairs in 1758. Again, despite the popularized view of an independent provincial population that wanted nothing more than to be left alone by the British, the evidence suggests the contrary. Many, in fact, welcomed British authorities in the hope that they might resolve longstanding issues. Thus, if British intervention might alienate those on the losing end of their decisions, it might also ensure the fervent support of the winners.

That local political conflicts, Native American diplomatic controversies, and competition between the various colonies persisted after the Seven Years' War suggests the failure of British officials to resolve those disputes. The British thus disappointed all interested parties, but it resulted as much from what they did not do than what they did do, as it is so often portrayed. This failure may have resulted in the conclusions made by some historians that, as Ward put it, the British officers proved inept in the eyes of the colonists. Forbes, and the other officers in North America who found success, however, did not demonstrate ineptitude. After 1757, they defeated a well-entrenched enemy which had mastered warfare in North America and consequently dominated the conflict for three years between 1754 and 1757. Instead, historians have perhaps confused their apathy for ineptitude.

The British officers who failed to resolve colonial disputes did not do so from ignorance but because of their differing goals, ambitions, and world views. Forbes attempted to placate the interest groups he encountered, but only to the extent to which he needed to in order to keep them supportive 
of his efforts. He thus demonstrated little interest in shaping the post-war colonial environment but instead focused entirely on completing his objective. Officials in Great Britain appeared to be similarly oriented. For the colonists, this unswerving commitment meant that local and provincial interests had been sacrificed in favor of imperial goals. The officers did not disagree with this assessment, but it proved a bitter to pill to swallow for the colonists that had hoped so fervently that imperial involvement in their affairs might produce more favorable results.

British agents and colonists found themselves in an awkward position in the mid-eighteenth century because the introduction of imperial authority unsettled the status quo. The colonies had established systems of local authority, diplomacy with important native communities and negotiation with neighboring colonies. British agents, both the military and the Superintendents, threatened to overturn these structures. Their authority to do so was legitimate as it derived in some manner from the Crown. At the same time, however, directives from these individuals represented a new thread of imperial direction in local affairs. It remained unclear to those experiencing this transition exactly how British authority might interact with honored local institutions. The British agents generally mirrored this opaque situation by acting in a manner that demonstrated their own indecision about their power. When situation became critical, however, British agents assumed that their royal authority superseded local structures. Although the colonists periodically questioned this assumption, they proved willing to adopt the premise when it suited their ambitions.

In attempting to dig through the nuances of colonial interaction with agents of imperial authority in Pennsylvania, three principal avenues of inquiry need to be followed. First, what exact goals and motives did officials in the London metropole have for the Pennsylvanian periphery? The historiography has generally portrayed Pitt as the mastermind behind Great Britain's victorious war measures and its subsequent imperial expansion during the Seven Years' War. This reality, however, appears much more complicated than the traditional view. North American operations during the 
conflict had been separated into two distinct regions-the Northern and Southern Districts. The British consciously kept resources, imperial agents, and troops separate, often in minute detail, between these two districts. As the northernmost colony in the Southern District, Pennsylvania thus experienced the conflict much differently than the New England colonies and New York. Consequently, an evaluation of the imperial goals and expectations in Pennsylvania, and the south in general, proves necessary. At the same time, it must be recognized that political realities in both London and Philadelphia meant that these goals and expectations developed through intense political discourse. How exactly, therefore, did these discourses impact the plans sent to the Southern District in 1758 ?

Understanding how imperial agents in North America attempted to correlate these directives from the metropole with the realities of the colonial periphery proves additionally instructive. Distance and resultant communication difficulties necessitated wide latitude of action and decision-making for Britain's agents in North America in the mid-eighteenth century. Local realities, moreover, often diminished the practicalities of ideas formulated on the opposite side of the Atlantic Ocean. How closely, then, did the imperial agents follow these politically expedient plans from London and to what extent did the colonists help shape their direction?

Finally, a detailed reexamination of how Pennsylvanians reacted to these imperial plans and agents appears necessary. While the entire population had no input on the imperial plan, many had a similar lack of influence in provincial matters as well. Thus, it proves imperative to determine to what extent an individual's position in Pennsylvanian society influenced their interactions with the influx of imperial authority in 1758 and to what degree factions and individuals sought a greater relationship with imperial agents to improve their place in society.

By addressing these questions with a more narrow scope than previously done, a clearer picture of the results of interaction with imperial policy is achieved. Thus, this case study offers a more nuanced description of colonial relationships with imperial authorities in the mid-eighteenth century than those 
offered by broader studies. Yes, colonists may have begun to question their relationship to Great Britain as a result of their interaction with British agents, but the particulars of this negativity is not as simple as many scholars have suggested. The usefulness of this more localized approach to evaluating colonial sentiment also adds a new conceptual framework with which to explore imperial relationships among the thirteen North American colonies.

Throughout the work, the term "agents of imperial authority" is adopted to refer to the figures in Pennsylvania that derived their legitimacy from Great Britain. While this moniker proves useful in collectively identifying these individuals, it should not be assumed that they all shared the exact same directives and agendas beyond their general commitment to Great Britain. The military officers, for example, owed their authority to the Cabinet whereas the Superintendents of Indian Affairs were connected to the Board of Trade. In addition, these two entities were actively engaged in a struggle for influence in Great Britain. It might be assumed that their rivalry was mirrored by their representatives in North America, but despite the presence of some cross-purposes the Superintendents generally recognized the preeminence of their military counterparts during the conflict and consequently did not openly undercut their authority in the presence of the colonists. Regardless, any competition between these entities does not necessarily prove critical to this study because the focus remains on the colonial perception of them collectively as agents of imperial authority.

It might further be noted that the individual identities of these individuals, particularly the Superintendents, could further complicate the interactions colonists had with them because some of them were colonists themselves. George Croghan was considered by his contemporaries to be motivated by personal interest, William Johnson by his attentiveness to the needs of the Iroquois Confederacy and Edmund Atkin to his connection to South Carolina. While these assessments were not necessarily entirely erroneous, it needs to be recognized that critics of these individuals blamed their 
ability to promote their private interests to the authority they had been given by the Crown. Therefore, what remains important is the recognition that the colonists associated their power with Great Britain.

Colonial governors present a bit more muddled picture. While the executives of royal colonies might be directly connected to British authority, Pennsylvania's governors were directly associated by the populace with the proprietorship. While the power of the Penns might be extrapolated back to royal authority, Franklin's attempt to replace the proprietors with Crown rule demonstrates that Pennsylvanians viewed their governors as separate entities. For the purpose of this study, therefore, Pennsylvania's governors are not considered agents of imperial authority.

As the study attempts to offer a new and more nuanced examination of colonial interactions with imperial agents of authority during the Seven Years' War than previous works, it is imperative to identify specific and individual groups to avoid the generalized descriptions so often offered. The study will not, however, break down responses to imperial authority by racial, ethnic, or religious entities (with the exception of the Quakers, who will be treated as a concrete political faction) because evidence suggests that these groups reacted against one another locally but demonstrate very little collectivity in their responses to imperial agents. The Germans, for example, generally deferred to Quaker leadership in matters political. Therefore, the study attempts to examine the responses of the various political communities against imperialism, most notably that of the popular and proprietary factions in Pennsylvania.

The study begins with a description of these political factions and explores their ideological orientation. It explores the background of their conflicts leading up to the Seven Years' War and establishes the extent to which both political elements had reached out to British authorities to abrogate their disputes. This is followed by a thorough examination of British politics during the Seven Years' War. It establishes the extent to which imperial policy as developed by the current Cabinet was negotiated and how this affected the views about the role of the colonies in the nation. It further 
explores how this view dictated the goals, plans and expectations Great Britain had for the colonies during the conflict.

This discussion of imperial politics is followed by a return to Pennsylvania with an evaluation of the interactions of military authorities with the local political factions. It explores the attempts of both factions to harness the strength of British officers to defeat their competitors and discusses the extent to which negotiation developed in these encounters. The study next turns to Native American diplomacy in Pennsylvania and introduces the role Superintendents and their deputies played in colonial politics along with the continued presence of military officers in these affairs. As British authorities attempted to increasingly regulate and unify negotiations with natives, colonial interests continued to maneuver to ensure the success of their interests. The discussion continues by incorporating a similar evaluation of diplomacy with the southern native allies who flooded into Pennsylvania in the second half of the 1750s. Competition for control of diplomacy with the southern allies introduces the interests of rival colonies to those of Pennsylvania. The study thus concludes with an evaluation of how Pennsylvania and its southern neighbors, most significantly Virginia, maneuvered to harness British authority to defeat the aims of one another.

These discussions thus present a very different picture than that offered by other evaluations of the breakdown of colonial relations with Great Britain in the Seven Years' War. Local political factions, as well as the province as a whole, initially viewed British authority as an effective tool to be utilized in their disputes. This does not mean, however, that they blindly accepted the ability of imperial agents to dictate to them. For while they actively engaged British authority when it suited their interests, elements in Pennsylvania likewise rejected British authority when it conflicted with their ambitions. Therefore, it reasonably follows that colonial disaffection with Great Britain, at least in Pennsylvania, resulted not entirely from personally negative interactions with arrogant or ignorant British officers or with the destructive imperial policies enacted after the war, but instead from dissatisfaction with the 
receptiveness of British authority to rule in favor of local and provincial disputes. The failure of British agents to resolve local disputes consequently exacerbated existing issues while simultaneously raising new ones. 


\section{Chapter 1: Pennsylvania Provincial Politics}

Pennsylvania in the first half of the eighteenth century had been designed to be a place of harmony. Despite this lofty goal, the colony had succumbed to intense internal political rivalries by the 1750s. Throughout this period, the colony's proprietary status had kept it significantly isolated from direct involvement in broader British imperial affairs. This all changed in 1758 when General John Forbes arrived to command thousands of British and provincial troops in Pennsylvania. Overnight, Pennsylvania became a focus of imperial attention. For the factions within the colony, the direct presence of British agents of imperial authority presented a dangerous, yet possibly beneficial, opportunity to present their views in the hopes that a favorable resolution might be brokered.

William Penn founded Pennsylvania in an effort to establish a "peaceable kingdom" on earth where religious freedoms and economic prosperity might be pursued by those willing to cross the perilous Atlantic and carve out new homes and opportunities in the New World. The ideals remain noble, but the realities proved starkly different. The colony of Pennsylvania was neither founded nor settled by saints but rather by humans with all of their inherent petty squabbles and ambitions. The Penn family, despite the founder's lofty ideals, increasingly expected the province to be a source of perpetual wealth, while the citizens simultaneously emphasized their own self-interests and demanded greater control over the policies of Pennsylvania. These clashing goals led to a century of conflict between the proprietors and many of the inhabitants of the colony.

While establishing Pennsylvania, Penn proceeded to lay out the parameters of the government in his First Frame of Government in 1682. This constitution guaranteed freedom of worship, the right to a fair trial, protections against unjust punishments, and free elections. In sum, the First Frame attempted to safeguard the rights of free Englishmen. In a move that his heirs likely regretted, the founder included provisions for amendments to the constitution to ensure that the government would evolve with the times. Yet despite these rather open-minded provisions, the First Frame ensured that 
Pennsylvania would remain firmly under the control of the more aristocratic elements of society. It did provide for a three branch government, composed of the governor, Council, and assembly, but the constitution vested all legislative power in the hands of the Council-a body made up of the first purchasers of five thousand acres in the colony. Smaller land-owners comprised the assembly which possessed a sort of veto power over the Council, a status reminiscent of the tribunes of Rome, but possessed no independent legislative power of its own. Thus, according to the First Frame, middling members of Pennsylvanian society might block legislation passed by the Council that they found particularly troubling, but they could not pass legislation of their own no matter how necessary they might find it.

As a result, few citizens of Pennsylvania embraced the First Frame of Government from its inception, leading to a series of alterations in 1683 and 1696. Most notably, the threat of a royal takeover of Pennsylvania led many colonists, regardless of economic status, to support ceding more authority to the locally elected assembly at the expense of the appointed (be it proprietary or possibly, in the future, royally appointed) Council. By 1701, however, the need for a radical alteration had become apparent to, or forced on, Penn leading to the establishment of the Second Frame of Government in 1701. The Second Frame of Government stripped the Council of all legislative authority. Instead, legislative initiative was to reside exclusively with the Pennsylvania Assembly. This radical alteration of the arrangement of government came to be known as the Charter of Liberties, but the governor retained the right to appoint a Council to assist with the executive responsibilities of that office. The Council, henceforth, became the home of elite Pennsylvanians intent on upholding proprietary privilege and by extension their own personal interests in the colony and abroad. ${ }^{18}$

\footnotetext{
${ }^{18}$ For a deeper discussion of the early constitutional debates, see Scott D. Gerber, "William Penn and the Origins of Judicial Tenure During Good Behavior, “ The Pennsylvania Magazine of History and Biography, Vol. CXXXVI, No. 3 (July, 2012): 233-252; Guy Franklin Hershberger, "Pacifism and the State in Colonial
} 
Once the essential functions of legislation devolved to the Assembly, the politics of Pennsylvania took on a markedly democratic appearance. This did not so much result from the rise of an elected assembly alone, but rather the demographic diversity that precluded the emergence of a homogenous voting block that could dominate the Assembly seats in Philadelphia. The colony had previously contained pre-existing Swiss and Dutch populations but had also attracted Anglican and Quaker English and Welsh settlers. Scottish and Scotch-Irish Presbyterians and German Lutherans and Moravians also began to populate the colony by the eighteenth century. This diversity might have promoted democratic deadlock in the Assembly, but remarkably the opposite emerged in Pennsylvania during the first half of the eighteenth century. ${ }^{19}$

The Scotch-Irish Presbyterians developed a reputation for independent action in Pennsylvania. Presbyterians, as had been acrimoniously noted by their Anglican competitors in the province, possessed a deeply rooted ecclieastic tradition of representative democracy within the church hierarchy. Despite this independent democratic tradition amongst the Presbyterians, the church remained deeply divided on a number of issues. Those issues included the role of church members in secular society. A significant portion of Presbyterians, those calling themselves Covenanters, consequently disavowed participation in civil government reminiscent to the stance taken by many Quakers in the mid-eighteenth century. ${ }^{20}$

The German populations of Pennsylvania presented a similar problem. Because they established distinct settlements, the Germans threatened to create voting blocs that might have overturned the representative government as established in the Second Frame of Government. Much like their Presbyterian neighbors, however, the Germans largely eschewed direct participation in

Pennsylvania,” Church History, Vol. 8, No. 1 (March, 1939): 54-74; Wellenreuther, “Quest for Harmony,” $537-$ 576; Wendel, "Keith-Lloyd Alliance," 289-305.

${ }^{19}$ Hilary Lloyd Yewlett, "Early Modern Migration from the Mid-Wales County of Radnorshire to Southeastern Pennsylvania, with Special Reference to Three Meredith Families". Pennsylvania History: A Journal of Mid-Atlantic Studies. Vol. 79, No. 1 (Winter, 2012): 1-32.

${ }^{20}$ Bankhurst, "Looking-Glass for Presbyterians," 317-348; Fisk Jr., "Diary of John Cuthbertson," 455-458. 
provincial government. Instead, the German population tended to emphasize autonomy on the local level, largely a response to the repressive governments they had left in Europe, in exchange for relative acquiescence in colonial politics. $^{21}$

In both instances, that of the consciously inactive Presbyterian Covenanters and the generally apathetic Germans, popular provincial politics generally devolved onto the Quaker elite that had played such a prominent role in the development of the colony. Such devolution should appear natural, as both the Presbyterians and Germans felt relatively comfortable leaving provincial politics to the Quaker Assemblymen, who had proved through both reputation and action to have been relatively trusty stewards of the public trust. However, this surprising yet natural alliance laid the seeds for the vitriol that developed in the first half of the eighteenth century. For as the Quaker Assemblymen became increasingly allied with the popular politics of the majority of Pennsylvania's population, those that continued to support the prerogative of the proprietors became increasingly wary of this popular interest. A clear demarcation of interests, with two diametrically opposed visions for the future of the colony, developed as a result. ${ }^{22}$

On one side stood those who supported the prerogatives and powers retained by the proprietors as a shield against what they perceived as a whimsical and irresponsible general populace. Referred hereafter as the 'proprietary faction', this group believed strongly that constitutional balance had been lost in favor of a dangerously democratic political system where the Assembly practiced what today would be called 'popular politics' by catering to the interests of the new ethnic voting blocs emerging in the colony. Members of the proprietary party increasingly used the words 'people' and 'assembly' interchangeably, demonstrating the development of such a viewpoint in the first half of the eighteenth century. While private communication between members of this faction and their

\footnotetext{
${ }^{21}$ Häberlein, “German Migrants,” 555-574; Tully, "Englishmen and Germans,” 237-256.

${ }^{22}$ Tully, "Englishmen and Germans," 240.
} 
antagonists suggests overlapping mutual self-interest in many financial matters, the democratic nature of the Assembly ensured a responsiveness to the populace deemed troubling by those supporting the power of the proprietorship. By seeking greater executive control for the proprietors and their agents, these individuals idealistically believed that they represented the true interests of the people by virtuously guiding their passions. Speaker of the Assembly Isaac Norris recognized the proprietary faction's stance even as he vehemently opposed it in the elected legislature. "[O]ften they have declared this Truth upon our minutes" he noted in reference to the responsibility of officeholders to be concerned with the well-being of the people. ${ }^{23}$ They likewise argued that their model of colonial government more closely followed the framework and traditions of British representative government. In defending this more paternalistic vision of government, the supporters of the proprietors established strict mercantilist economic policies, such as instituting quality inspections of exported goods, to ensure the good reputation of the colony abroad and to ensure that universally beneficial mercantile activities did not suffer from the dishonest dealings of any individual. They also developed a fierce resistance to any appointments by the Assembly as a violation of the executive powers of the governor, and by extension, the proprietors. By appointing a wide range of government agents, including commissary overseers, Indian commissioners, and Comptrollers of Duties, the Assembly had begun to develop a patronage network ensuring the support of officials conveniently located in important jobs throughout the colony. To combat this, the proprietary factions appointed its own series of commissioners. Many of them served for life but every one answered directly, and owed their position, to the governor and by extension proprietor. Insulated from popular politics, these individuals could be counted on to support the interests of the Penn family and uphold the more paternalistic vision of Pennsylvanian government.

\footnotetext{
${ }^{23}$ Isaac Norris to Benjamin Franklin, April 4, 1757, Isaac Norris Letterbook (hereafter INL), 1154, Historical Society of Pennsylvania (hereafter HSP), Philadelphia.
} 
As might be expected, governors, Councilmen, significant portions of the mercantile community, and those appointed by the proprietors tended to favor this faction. ${ }^{24}$

The so-called "popular party," as the proprietary faction called them, conversely supported the power of the more democratically elected assembly and local governments as protection against the unsettling possibility of proprietary tyranny. The province's Quakers dominated this coalition by drawing broad support from the diverse population who deemed the Friends reliable stewards of their interests due to the appearance of legitimate responsiveness to the concerns of the electorate. This opposition to the proprietorship emerged from three principle factors--a deep commitment to localism, a significantly higher respect for democratic, rather than hierarchal institutions, and the deeply held belief that the proprietors intended to rule the colony in a tyrannical fashion. ${ }^{25}$

The localism that generally prevailed in Pennsylvania in the mid-eighteenth century meant that local county government proved more trusted to many citizens than provincial institutions. The level of comfort residents felt within their county government resulted from several, rather logical developments. The county court system established in the colony generally meant that most people had access to a locally managed judicial system. Scholars have demonstrated that Pennsylvanians utilized these courts to resolve criminal, civil, and financial issues frequently, with many individuals finding themselves in court multiple times throughout their lives. The county courts, as a tangible entity in the lives of local peoples, thus served as a vital link between the people and the government as a whole. The courts, as an extremely visible symbol of responsive government, rather than the slowmoving and more distant provincial government, had a better chance to earn the trust and the loyalty of

${ }^{24}$ Wellenreuther, "The Quest for Harmony in a Turbulent World," 537-576; Wendel, "The Keith-Lloyd Alliance," 291; Johnson, "What Must Poor People Do?," 117-153; Glenn to the Lords of Trade, 1750 in Forbes Papers (hereafter FP), GD 45/2/1, Scottish National Archives (hereafter SNA), Edinburgh. While Glen speaks more generally of the colonies as a whole, his comments are most certainly applicable to the debates ongoing in Pennsylvania.

${ }^{25}$ Joan de Lourdes, "Elections in Colonial Pennsylvania," The William and Mary Quarterly, Third Series, Vol. 11, No. 3 (July 1954): 385-401; Wellenreuther, "The Quest for Harmony in a Turbulent World," 557. 
the people. In addition, residents considered themselves closely linked to their elected officials. On the local level, each county possessed three commissioners who served three-year terms. These commissioners tended to be much less wealthy than appointed officials, thus indicating that when possible, Pennsylvanians elected people considered similar to themselves and therefore people they trusted as reliable stewards of their communal interests.

Patterns of economic and religious development additionally fostered county localism. Economic exchange often occurred rather informally, with deals made and credit extended through oral agreements based upon individual reputation. This system persisted despite the great fluidity of Pennsylvania's population because letters of introduction from mutual acquaintances minimized the risk of dealing with strangers and newcomers. The cozy nature of local economic exchange does not, of course, suggest the self-sufficiency of individual communities. Global networks of exchange incorporated even the most remote settlements in Pennsylvania, but they often did so unobtrusively through mercantile middlemen and the company stores of the colony's fledgling industries. Both of these sources of external exchange appeared part of the community fabric and thus did not diminish the prevailing localism. Religious communities also favored localism as a means to ensure the highest degree of autonomy. Many Presbyterians, unlike the majority of Pennsylvanians, eschewed even the locally elected civil legal courts in favor of resolving disputes amongst the even more insulated church membership. As a result of this intense localism, most rural residents of Pennsylvania gravitated towards the popularly and locally elected Assembly rather than the more distant and appointed offices occupied by the proprietary faction. ${ }^{26}$

\footnotetext{
${ }^{26}$ For discussions of the county court system, see Becker, "People and the System," 137 \& 149. For a discussion about county political representation, see Clair W. Keller, "The Rise of Representation: Electing County Officeholders in Colonial Pennsylvania," Social Science History, Vol. 3, No. 3/4 (1979): 139-166. For a discussion about local economic exchange, see Mark McKinney Schweitzer, "Contracts and Custom: Economic Policy in Colonial Pennsylvania," The Journal of Economic History, Vol. 45, No. 2 (June, 1985): 463-465; Michael V. Kennedy, "'Cash for Turnips': Agricultural Production for Local Markets in Colonial Pennsylvania, 1725-1783," Agricultural History, Vol. 74, No. 3 (Summer, 2000): 587-608. The relationship between international merchants
} 
Beyond localism, the political environment in Pennsylvania fostered a sense of egalitarianism that rejected forms of hierarchal authority represented by the proprietary faction. Electoral politics in the colony had evolved to be fairly responsive to the individual citizen because the voting requirements remained comparatively open. The franchise extended to those possessing either fifty acres or fifty pounds of property, the secret ballot had been adopted, and citizens voted for a wide range of significant officials and legislators including their own Justices of the Peace. In addition, laws had developed requiring the rotation of individuals serving in county offices ensuring that no entrenched political elite formed in rural areas to command the obedience of voters. This development, combined by the failure of a true and significant economic elite that could be readily identifiable by overt symbols of wealth to form in rural areas led to a sense that politics existed to serve the people. A marked lack of deference to authority consequently followed. Pennsylvanians demonstrated such sentiment in several ways. Many routinely ignored provincial laws, such as serving on night watches. The people generally tolerated counterfeiting due to the frequent scarcity of hard currency. Even provincial taxes proved difficult to collect effectively in outlying areas. Finally, if the members of the proprietary faction are to be believed, country folk frequently insulted magistrates and intimidated local sheriffs. ${ }^{27}$

In addition to the emergence of acute localism and egalitarianism, many Pennsylvanians gravitated towards the popular faction because they feared the tyrannical domination of the proprietors

based in Philadelphia and rural partners is demonstrated in Mark Abbot Stern, David Franks: Colonial Merchant (University Park, PA: The Pennsylvania State University Press, 2010). For a discussion of this Presbyterian practice, see Fisk, "The Diary of John Cuthbertson," 451.

${ }^{27}$ For discussions about electoral politics, see Keller, "Rise of Representation," 152; Johnson, "What Must Poor People Do?," 123; Leonard, "Elections in Colonial Pennsylvania," 400-401; Gerber, "Origins of Judicial Tenure," 241; Wendel, "Keith-Lloyd Alliance," 294-295 \& 305. Discussions about deference in Pennsylvania can be seen in Alexander, "Deference in Colonial Pennsylvania," 422-436; Tully, "Englishmen and Germans," 292; Ward, Breaking the Backcountry. Interestingly, this model of the breakdown of deference due to localism and egalitarianism in rural communities has been identified in Virginia as well as suggested in Warren R. Hofstra, The Planting of New Virginia: Settlement and Landscape in the Shenandoah Valley (Baltimore: The Johns Hopkins University Press, 2004). 
and their supporters. ${ }^{28}$ According to those ascribing to this viewpoint, the heirs to William Penn actively sought to disrupt the Charter of Liberties and the authority it had allowed the Assembly to acquire in the first half of the eighteenth century. Assemblymen and their supporters reacted with a mixture of hostility and disappointment when governors, for example, exerted themselves with the remaining executive powers of that office. Speaker Norris specifically feared that governors, in this case Robert Hunter Morris, did "not seem sufficiently guarded against ye abuse of it [power]." ${ }^{29}$ As Morris and the Assembly repeatedly clashed over the respective powers of the two institutions, Norris and his allies became increasingly disgusted with the governor, accusing him of hiding behind instructions given to him by the Penns at the expense of the colonists' well-being. ${ }^{30}$ In response to the wildly contested tenure of Morris, Norris rested his hopes on the appointment of a governor "unfettered by Proprty Instructions" and "equally free from Ministerial Fetters." ${ }^{11}$ The Speaker set his sights on Thomas Pownell, former Lieutenant Governor of Massachusetts. When in 1757 Pownell refused the governorship of Pennsylvania to assume control in Massachusetts, presumably because he would have a freer hand without the oversight of an interested proprietorship, the colony proceeded to be presided over by a continued string of governors deemed more attentive to the interests of the Penns than the needs of the province's citizens. ${ }^{32}$

While the popular faction continued to hold governors in low regard, they certainly recognized the difficulties confronting individuals occupying the office. As Norris's assessments indicate, proprietary instructions limited the freedom of action of governors who remained beholden to the Penn family. The Assembly simply hoped for an individual who might prove willing to rise above the situation and act on behalf of the people's interests. If perhaps a slim hope, it continued to exist as Norris and his

\footnotetext{
${ }^{28}$ See Wendel, "Keith-Lloyd Alliance," 299.

${ }^{29}$ Norris to John Fothersgill, June 161756 in INL, 1154, HSP.

${ }^{30}$ Norris to Charles, November 27, 1755 in Ibid.

${ }^{31}$ Norris to Charles, June 16, 1756 in Ibid.

${ }^{32}$ Norris to Pownell, August 24, 1757 in Ibid.
} 
allies attempted to work around obstructionist governors they considered blind and obedient servants of the proprietors. Due to this realistic understanding of the precarious position of the province's governors, the popular faction reserved its most virulent animosity for the colony's Councilmen.

Although the governor's attentiveness to proprietary 'instructions' and purported refusal to act in the interests of the people might be reluctantly understood, the similar attitude among Councilmen proved intolerable. These men came from the colony and were deemed, despite their general wealthier status, as peers. Unfettered by direct control by the proprietors, Assemblymen came to suspect that they acted upon personal interest at the expense of the public. The popular faction consequently came to accuse them of at worst controlling the governors, at best duping them into catering to this selfinterest. ${ }^{33}$ By upholding the position of the proprietors, the Assemblymen argued, the Councilmen maintained their positions of power from which they derived great wealth utilizing a "Rage of lawless Power. ${ }^{\prime 34}$ While such a sentiment had existed in the first half of the eighteenth century, the Seven Years' War increased the intensity of the debate because the government quarreled among itself as its people began to be killed, captured and displaced in increasing numbers.

The political conflict in Pennsylvania became exacerbated with the eruption of the North American phase of the Seven Years' War in 1754. It might have been avoided had General Edward Braddock, sent by Great Britain to resolve the conflict, not been defeated so dramatically by the French and their Native American allies in the summer of 1755 . The defeat emboldened many Native Americans in present-day Western Pennsylvania to cast their lot with the French and wildly successful raiding parties consequently descended upon the colony's western settlements. At the time, Pennsylvania possessed no formal military institution having not needed one during its remarkably peaceful existence. William Penn had established a traditional reliance on the Royal Navy, natural

\footnotetext{
${ }^{33}$ Norris to Franklin, November 24, 1757 in Ibid.

${ }^{34}$ Norris to William Franklin, February 4, 1758 in Ibid.
} 
defenses, and negotiations with native populations to maintain security in the province. The absence of any type of military organization consequently proved disastrous, as the raids killed or displaced thousands of settlers. ${ }^{35}$ The situation became so dire, and the government appeared so incapable of protecting its citizens, that westerners threatened to attack the provincial capital as early as April 1756, only nine months after the disastrous defeat of Braddock. ${ }^{36}$ Raising some type of military establishment became the preeminent debate in Philadelphia nearly overnight, but the obviousness of the imperative did not equate to the "crossing the aisle" by politicians. Instead, the same old debates about popular versus proprietary rights emerged in the midst of the crisis.

Thus, Pennsylvania found itself in a serious crisis after the British defeat in the summer of 1755. The political squabbles between the proprietary and popular factions had paralyzed the colony and ensured that it relied upon the British military to succeed rather than preparing for its own defense. Three years passed before the British again campaigned in Pennsylvania in any significant way. The province's politicians thus found themselves compelled to reengage the issue in an attempt to defend its citizens.

When news of French victory in the summer of 1755 reached Philadelphia, the popular faction acted quickly to propose a military establishment concurrent with their philosophical beliefs. Led by Benjamin Franklin in this instance, the Assembly suggested a militia bill similar to those of other colonies with one distinct difference. Franklin recognized that the Charter of Liberties did not allow the provincial government to compel service from the significant Quaker pacifist population. He likewise reasoned, with that in mind, that it would thus be inconsistent to exempt Quakers but compel the remainder of the citizens. Consequently, the proposed Militia Bill of 1755 asked for voluntary service. Although many turned out voluntarily, the need for a more regulated militia quickly became apparent

${ }^{35}$ Jeffrey M. Dorwart, Invasion and Insurrection: Security, Defense, and War in the Delaware Velley, 1621-1815 (Newark, DE: University of Delaware Press, 2008); Ward, "La Guerre Sauvage".

${ }^{36}$ Norris to Charles, April 29, 1756 in Ibid. 
and subsequent militia bills included mandatory participation. Regardless, the militia concept agreed with the popular faction because it retained the essential functions of liberty and democracy they felt the proprietary faction threatened. Similar to other colonial militias, citizens elected their own officers and thus remained largely outside the direct control of the government and the units themselves would be completely composed of citizen soldiery. ${ }^{37}$

The proprietary faction, not surprisingly, felt differently. Fearing the threat a democratically elected militia might pose to the executive branch of the government, they instead favored the establishment of a temporary standing army. By controlling the commissioning of officers, the proprietary faction hoped to develop a new patronage network within which it might reward its supporters while likewise recruiting new ones. The relatively generous pay for the troops might additionally foster loyalty among those who served in the ranks. At the very least, those in the provincial force would prove responsive to the proprietary faction in the short term because of the executive's constitutional authority and thus serve as a counterbalance to the more democratic militia organizations. Robert Hunter Morris, perhaps the most unpopular governor in Pennsylvania during the Seven Years' War, supported this stance as the elections approached at the end of 1755.

The emerging need for protection during the Seven Years' War had thus neatly framed the power struggle within Pennsylvania and factional politics unsurprisingly reached a fever pitch during the election season as each side made its case to the colony's citizens. The popular faction preyed upon fears inherited from the Old World, arguing that a professional standing army could only be intended to suppress liberties. Likewise, the proprietary party specifically targeted the province's German population, suggesting that the possibility (realized the following year) of compulsory service in the militia appeared reminiscent of the demands made on many Germans by the very rulers they had fled in Europe. The standing army would be raised on a volunteer basis, they argued, and thus represented an

\footnotetext{
${ }^{37}$ Swartz, "A Mixed Multitude," 213.
} 
economic or patriotic opportunity rather than a forced service as future militia bills were likely to require. The popular faction retained control of the Assembly whereas the supporters of the proprietors, not subject to the election, indisputably held onto power in the executive branch. Both plans subsequently went forward as both a militia and a 'standing' provincial army ultimately formed. To support these establishments, the competing governmental elements did manage to pass a bill appropriating $£ 60,000$ to the military for 1756 . Few celebrated this misleading solidarity because it simply resulted in the reemergence of the same philosophical debates over new specific issues. ${ }^{38}$ When it came time to raise the money to support military development, property taxes emerged as the new essential point of discord. While citizens of the colony had previously been required to pay tax on their holdings, proprietary land, technically including all unclaimed land in the province, had traditionally been exempt. The reasoning behind such a disparity seems quite logicalhaving to pay equal taxes on all unclaimed, and thus unproductive, lands in Pennsylvania would have driven the Penn family into complete bankruptcy. As tensions mounted, however, the popular faction fastened onto this issue demanding quid pro quo. If the government expected all citizens to pay property taxes, then the Penns should not be exempt. Refusal to act with equanimity with regular Pennsylvanians clearly suggested the specter of tyrannical rule to those predisposed to believe so because any exemption appeared to indicate that the Penns considered themselves above the laws imposed on the rest of society. No governor hoping to keep his position could sign into law any legislative bill passed by the Assembly requiring the Penns to contribute property taxes. The popular faction found cause to attack their antagonists on the Council on the matter as well. Aware that many of these elite Pennsylvanians maintained substantial estates in Delaware, at the time technically part of Pennsylvania, they demanded that property taxes be levied on these estates. Although Delaware

${ }^{38}$ Ibid, 208, 211 \& 214; Dorwart, Invasion and Insurrection; Wellenreuther, "The Quest for Harmony," 548 \& 561; Deputy Governor Morris, October 28, 1755 in Papers Relating to North America (hereafter PRNA), Vol. 2, 33029, British Library (hereafter BL), London. 
shared a governor with Pennsylvania, it possessed its own assembly which proved much more compliant to the Councilmen than that of the Quaker colony. As a result, the Councilmen avoided the taxes, but offered instead to send Delaware's militia to the support of Pennsylvania. Unable to exert their legislative authority into Delaware, the Pennsylvanian Assemblymen sardonically thanked them for their "contribution." 39

With the property tax impasse unresolved, little military development of consequence resulted. As the Indian raids continued, Pennsylvanians increasingly became irate with the apparent inaction of their government. To redirect the popular outrage, the proprietary faction attempted to spin the situation by blaming the impasse on the Quaker-dominated Assembly. They consequently attempted to build upon the well-recognized pacifism of Quakers by suggesting, somewhat effectively, that the Quakers blocked any military expenditure bill on conscientious objections. The subsequent evacuation of Quaker Assemblymen in 1758 and resultant passage of an effective military expenditure bill appeared to many as validation of the proprietary claim. However, most scholars recognize this as a conciliatory measure by the Quakers. As early as the 1740s, Quakers had passed military measures for the colony without abjectly contradicting their pacifism. By passing measures generically for "the King's use," or by buying military goods such as grains of gunpowder and surreptitiously listing it as "grain", Quakers had long devised ways to provide for essential defense without directly and abjectly partaking in the activity. Despite these realities, the anti-Quaker sentiment prevalent within many of the smaller, less powerful ethnic and religious minorities within Pennsylvania led to some degree of recognition of the proprietary faction's argument, regardless of its actual validity. This antipathy led to most of the Quakers resigning from the Assembly in 1758 in an act largely designed to discredit the proprietary argument after the fact as the new non-Quaker Assemblymen continued the same old arguments without having the pacifistic

\footnotetext{
${ }^{39}$ Wellenreuther, "The Quest for Harmony," 548; Swartz, "A Mixed Multitude,” 210; Norris to Charles, July 1, 1757 in ISN, 1154, HSP.
} 
stigma that had proven so useful to their opponents. ${ }^{40}$ Ultimately, an adequate supply bill passed in

April 1758 after the parties hammered out a tenuous and temporary measure whereas the proprietary estates remained tax-free in exchange for a promise from the Penns to provide a $f 5000$ 'gift' to the defense fund. ${ }^{41}$

As the disparate views of the factions developed over the first half of the eighteenth century, and intensified during the early years of the Seven Years' War, it became apparent to both sides that neither possessed the requisite power to entirely disregard the other. The proprietary faction firmly possessed the executive branch of the government represented by the governor and the advisory Council whereas the popular faction held sway in the legislative assembly. Therefore, both sought support from elements within Britain in their internecine struggle in the colony.

In an attempt to clear their most ardent opposition from the Assembly, the Penns had requested in 1740 that the Ministry remove Quakers from Pennsylvania's government. As this goal evolved, it eventually centered on the re-imposition of the Test Act, a legislative machination originally designed to keep Catholics in Britain out of civil office. Failure by the Ministry to act led to the publication of Reverend William Smith's A Brief State of the Province of Pennsy/vania in 1755 at the urging of proprietary supporters Richard Peters, James Hamilton, William Allen, and governor Robert Hunter Morris. Smith's polemic directly called for British intervention, by either the Ministry or the

\footnotetext{
${ }^{40}$ Hershberger, "Pacifism and the State," 67-68; Swartz, "A Mixed Multitude," 208; Wellenreuther, "The Quest for Harmony," 558 \& 564. Wellenreuther illuminates the difference within the Quaker fold of the Old Peace Testimony and the New Peace Testimony. According to the Old Peace Testimony, a belief held by many Pennsylvanian Quakers in the first half of the eighteenth century, Quakers were forbade the use of arms but not the raising of military funds as long as they were not involved directly in the disbursement of those funds. The New Peace Testimony, which became popular amongst Pennsylvanian Quakers during the Seven Years War, radicalized the tradition of pacifism. By rejecting this distinction, those that ascribed to the New Peace Testimony could not serve in government in any capacity during wartime without risk of being complicit with the resultant violence. Those that stepped down from the Pennsylvanian Assembly in 1758 appear to have belonged to both groups. Those that ascribed to the Old Peace Testimony appear to have stepped down for practical reasons, recognizing the popular prejudice against them and entrusting their viewpoints to similarly-minded non-Quaker Assemblymen. Others, who supported the New Peace Testimony, stepped down for more ideological reasons and refused to partake in any way with militaristic measures. It is these individuals that many, both at the time and afterwards, have assumed to have been the majority view of the Quaker multitude.

${ }^{41}$ Norris to Franklin, February 21, 1758 in INL, 1154, HSP.
} 
Board of Trade, in Pennsylvania to rescue the privileges of the proprietary faction. When this attempt to influence popular opinion failed to move the government, the Penn's once again pursued official channels, this time appealing to the Board of Trade to remove the Assembly's power to appoint provincial inspectors and place it in the hands of the governor. Although the Board expressed its sympathies, and despite the recommendation by some that intervention should be pursued, it declined to get involved. During the intervening years, the proprietary supporters also pursued a policy of bombarding various government officials with similar requests. The conflict continued into the 1760 s, as new issues and new coalitions altered the political landscape, but the pattern had been establishedthe proprietary faction considered the British government as their best hope at defeating the Assembly and its popular faction. At the same time, proprietary supporters recognized the slippery slope they treaded by pursuing imperial involvement in local colonial concerns. Any increase in imperial control in Pennsylvania might result in a subsequent decrease in proprietary power just as easily as it might result in a decrease of the power of the Assembly. Memories of William Keith's unsuccessful attempt to convert the province into a royal colony in 1718 probably haunted the Penns, but their options remained limited. Recognizing their inability to defeat the power of the Assembly on their own, the risks of arbitration from Britain needed to be accepted. ${ }^{42}$

Left to their own devices, the popular faction, and in particular the Quakers, probably preferred to battle the proprietary interests within the confines of Pennsylvania. As the unofficial war of words in Great Britain continued, however, English Quakers began to recognize the possibility of a major public relations defeat. The debate largely centered on Quaker traditions of pacifism. As a nearly defenseless

\footnotetext{
${ }^{42}$ For discussion about these appeals, see Arthur L. Jenson, "The Inspection of Exports in Colonial Pennsylvania," The Pennsylvania Magazine of History and Biography, Vol. 78, No. 3 (July 1954): 275-297; Sally Swartz, "A Mixed Multitude": The Struggle for Toleration in Colonial Pennsylvania, (New York: New York University Press, 1987), 217; Wellenreuther, "Quest for Harmony;" Wendell, "Keith-Lloyd Alliance," 295-296; Philip Haffenden, "Colonial Appointments and Patronage under the duke of Newcastle, 1725-1739," The English Historical Review, Vol. 78, No. 308 (July 1963): 432. William Keith served as Pennsylvania's Lieutenant governor from 1715 to 1718. When William Penn died, Keith conflicted with the founder's heirs and consequently attempted to retain power by unsuccessfully converting Pennsylvania to a royal colony.
} 
Pennsylvania reeled from unrelenting Indian attacks beginning in 1755 , the proprietary interests

increasingly portrayed, erroneously but generally successfully, the pacifistic Quakers as the sole reason for the colony's suffering and apparent inability to combat the French and their native allies. ${ }^{43}$ Hearing rumors that the British government intended to remove the Quaker legislators for the greater good of the Empire, the popular faction sought support from metropolitan entities as well. Similar to their proprietary opponents, they came to believe that only Britain might represent the source of power and authority necessary to finally assume full control of Pennsylvania. " "[Y]e want of a full authority or power to Exert our natural strength," Speaker Norris noted to a correspondent in England, "must be left to our superiors." ${ }^{45}$ The appropriate path to tread in Britain, however, proved difficult to determine for the popular faction. For just as Royal authority might threaten the prerogatives of the proprietors, it could simultaneously, many believed, threaten the liberties of the free citizens of Pennsylvania.

The Board of Trade and the Ministry both possessed historical claims to royally-supported prerogatives to oversee colonial affairs. As a consequence, and because reports reached Pennsylvania that the proprietary faction had tentatively approached these entities, supporters of Pennsylvania's Assembly made sure to make their position known to Royal officials. "[A] well-Judg'd spirited application to the Lords of Trade," Norris reported, "gives me good satisfactn. for . . . ye Disposition of

${ }^{43}$ Scholarship has shown that Quakers varied in their view of pacifism. Many took no issue with the raising of funds for defense spending, sometimes using interesting contrivances to make it acceptable to their faith. For example, they often used the generic term "For the King's use" when raising funds that they knew would be used for defense. On one occasion during King George's War, they donate gunpowder to New England but listed it as 'grain', an interesting play on words to make the donation more palatable. The first example of Quaker military legislation dates to 1701 when they approved the construction of defensive watchtowers as discussed in Dowart, Invasion and Insurrection. The real issue Pennsylvania Quakers had with defense spending early in the Seven Years' War was how the money was to be raised. The popular party insisted that Proprietary estates be taxed while the proprietary faction refused to such stipulations. This impasse led to the deadlock that left the province in such a defenseless state early in the conflict. The proprietary faction, however, seems to have been somewhat successful in portraying the Quakers as blocking defensive measures entirely out of pacifistic beliefs. For a discussion of various views of pacifism, see Hershberger, "Pacifism and the State," 54-74.

${ }^{44}$ Norris to Charles, November 22, 1755; Norris to Charles, April 22, 1756 both in INL, 1154, HSP.

${ }^{45}$ Norris to Charles, November 15, 1755 in Ibid. 
that Board." ${ }^{\prime 6}$ To further ensure that directives from Britain did not favor the proprietors, English Quakers working with their cousins in Pennsylvania brokered a deal with Lord Halifax, head of the Board of Trade, agreeing that Friends would step down from office in 1758. The Quakers made such a momentous move to undercut the claims being made by their opponents in Britain that their pacifistic nature blocked any meaningful defense measures and refocus the British government's attention on the refusal of the proprietors to allow any defense bill to be passed that taxed their estates in Pennsylvania. By shifting the blame, the Quakers hoped that a government embroiled in a global conflict would at the very least retain the status quo and in the best case scenario find a way to diminish proprietary prerogative to encourage a greater military effort from the province. The ministry as well did not appear a hopeful source of significant support for supporters of the colony's Assembly. ${ }^{47 ~ " I ~ h a v e ~}$ expected it [support] rather from a Parliamentary enquiry," Norris stated, "then from ye ministry." ${ }^{48}$ To that end, the popular faction directed most of its attention to winning Parliament to its cause.

The popular faction's ideological aversions to power structures that threatened liberty ultimately made it wary of working too closely with the royally-appointed government bodies as represented by the Board of Trade and Ministry. The arguments made by the monarchy and its supporters about its prerogatives too closely mirrored the arguments made by the proprietary party in respect to its powers in Pennsylvania. ${ }^{49}$ As a consequence, supporters of the rights of the Assembly

${ }^{46}$ Norris to Charles, February 4, 1758 in Ibid.

${ }^{47}$ Norris to Charles, November 24, 1757 in Ibid; Wellenreuther, "Quest for Harmony," 549; Schwartz, "A Mixed Multitude," 215-219. Other scholars have suggested that the Quakers proved willing to withdraw from political office in the mid-eighteenth century not as a consequence of the pacifism debates but rather from a deep aversion to the vitriolic political competition emerging in Pennsylvania. The move is thus cast as a spiritual movement seeking inner peace by removing themselves from the increasingly hostile debates. See Karen Guenther, Rememb'ring our Time and Work is the Lords": The Experiences of Quakers on the Eighteenth-Century Frontier (Sellingsgrove, PA: Susquehanna University Press, 2005).

${ }_{48}^{4}$ Norris to Charles, July 3, 1757 in INL, 1154, HSP.

${ }^{49}$ For a discussion about the relationship between proprietary and royal prerogative, see Antoinette Sutto, "The Borders of Absolutism: William Penn, Charles Calvert, and the Limits of Royal Authority, 1680-1685," Pennsylvania History: A Journal of Mid-Atlantic Studies, Vol. 76, No. 3 (Summer 2009): 276-300. 
came to regard Parliament as the "true guardian of English Liberty." "Wo "We hope Redress from a British Parliament," Speaker of the Assembly Norris declared to a correspondent in England, "who cannot be unsensible that if the colonies are oppressd and denied the Rights of Englishmen \& English subjects the oppression will not stop long there for Power is of an incroaching nature \& may take strides beyond the ocean as well as upon this side of it and I find by some of the publick papers this is the apprehension men of thought \& abilities have of it." ${ }^{51}$ Clearly, the popular faction had likened the political structures of Britain to their own in Pennsylvania. Accordingly, they considered all elements linked to the monarchy as dangerous and ultimately untrustworthy whereas the 'popularly' elected Parliament represented a like-minded legislative body committed to the defense of liberty and the rights of Englishmen.

To convince Parliament of the necessity of intervening in Pennsylvania, the Assembly elected Isaac Norris and Benjamin Franklin to travel to London to represent its interests. Isaac Norris deferred to Franklin citing the importance of his presence in the province as the head of the legislature. Franklin accepted the commission and departed for London in April 1757 armed with voting records proving the Assembly's willingness to pass defensive measures. ${ }^{52}$ In the event that Parliament did not prove as ideologically committed to defending liberties as the Assembly hoped, a second strategy developed alongside the dispatch of Franklin as the province's agent. To put additional pressure on Parliament to act in the interests of the popular faction, both the Assembly and the Quakers independently resolved to appeal directly to the British public. The Assembly consequently published their voting records while Quakers in England likewise issued public defenses of the actions of Pennsylvanian Quakers in the British

\footnotetext{
${ }^{50}$ Norris to Franklin, October 17, 1757 in INL, 1154, HSP.

${ }^{51}$ Norris to Richard Partridge, July 1, 1757 in Ibid.

${ }^{52}$ Norris to Charles, January 12, 1757; January 31, 1757; April 4, 1757 in Ibid.
} 
press. Both hoped that winning over the British public would ensure that a presumably responsive Parliament would prove reluctant to act against them. ${ }^{53}$

Both the proprietary and popular factions in Pennsylvania arrived at the mutual conclusion that any final resolution to their domestic political disputes might only derive from sources of authority in Great Britain. While such an appeal to Great Britain had previously been attempted, the pressures of the Seven Years' War and the deplorable conduct of the war in the early years suggests that the royal government might have been more receptive to the concept of real intervention in the 1750 s. The institutions from which such resolutions would be determined, however, proved varied. The antagonists explored options in both the royally supported Board of Trade and Ministry as well as the more popular elements represented by Parliament and the British public at large. The wide net cast by the factions indicates the opaqueness of political authority in Britain over its colonies, particularly a proprietary entity such as Pennsylvania. As Pennsylvanians made applications to these entities, it remained unclear which might decide to get significantly involved in the province's political affairs. The faction favored by British institutions proved equally unclear.

\footnotetext{
${ }^{53}$ Norris to Charles, January 19, 1757 in Ibid; Schwartz, "Mixed Multitude," 215-217.
} 


\section{Chapter 2: British Imperial Policy}

In 1749, Governor James Glen of South Carolina wrote a scathing letter to the Board of Trade extensively outlining problems within the colonies with the intent of making "us more beneficial to our mother Country and preserve our dependence upon the Crown." ${ }^{54}$ Glen had determined that too much authority had devolved into the hands of the people. "The Political Balance in which consists the strength and Beauty of the British constitution," he argued, "being here entirely overturn'd and all the weights that should Trim and poise it by different Laws thrown into the seale of the People." ${ }^{55}$ Many of the issues identified by Glen, as well as his ultimate solution, proved comparable to those assessments of the proprietary faction in Pennsylvania. He had found that most of the executive powers necessary for the effective governing of a colony, such as the right to tax and appoint officeholders in a variety of provincial commissions, had devolved onto the representative Assembly. In Glen's estimation, such an imbalance in power had led to the people developing an unacceptable sense of self-determination. He cited as evidence the increasing trend to pray for the Assembly rather than the King, the troubling belief among South Carolinians that they, rather than the Crown, owned the province's forts, and the growing production of local manufactures at the expense of British imports. To fix the problems, the governor requested the Board of Trade to intervene "with the constitution for supporting government and the Kings Prerogative ... not of the leveling Principles that Prevail too much here." ${ }^{156}$ Concurrent with the appeals made by Pennsylvania's proprietary faction, Glen concluded that the Board could best effect such change by restoring the executive powers to the Governor and the supporting Council.

Throughout the 1750s, numerous contemporaries of Glen from various backgrounds in Great Britain echoed the governor's concerns about the independent nature of the colonies. As early as the 1690s, William Penn had himself doubted the willingness of his colony to obediently follow directives

\footnotetext{
${ }^{54}$ Glenn to Lords of Trade, 1749, in FP, GD 45/2/1, SNA, Edinburgh.

${ }^{55}$ Ibid.

${ }^{56}$ Ibid.
} 
from the Crown. ${ }^{57}$ While Glen echoed Pennsylvania's proprietary faction in blaming the assemblies, others made demographic claims. A Scottish informant named Gordon reported to the Duke of Newcastle that "I have heard it frequently observed ... by men who have been long on that place [America] that the protestant part, of his majesty's American subjects, have long been ... such turbulent ungovernable people." ${ }^{158}$ According to Gordon, the natural troublesome nature of American colonists became exacerbated during the 1750 s by the dispatch of Scottish troops to the Continent. "[T]he scotch troops, now abroade in America . . . haveing been so ground'd in Ireland . . makes it most justly apprehend'd that they carry'd such a large porcion, of the bad blood of both nations with them to an other so halfe corrupt'd before as to indanger, infection if not most prudently observ'd, and purg'd." ${ }^{\prime 59}$ Similar to Glen, Gordon cited the refusal of these peoples to trade directly with Britain as evidence of their recalcitrance. To make matters worse, he intimated that colonists might be willing to repudiate Great Britain if the government attempted to interfere with colonial affairs too heavily. "I found them, most lofty in theire threats," he noted describing conversations held with American officers on parole, "that if this theire so nam'd mother Country, was not more Indulgent, to them, they had an other roofe to shelter under with other such like expressions." ${ }^{60}$ Isaac Norris of Pennsylvania confirmed the intelligence provided by Gordon. "I see by some Pamphlets put into my Hands a fondness (I fear under ministerial Influence)," he noted, "of modeling the colonies upon the French Plan and under the direction of particular Boards if this should ever succeed the ... colonies will be evacuated as fast as possible and flourish backwards." ${ }^{61}$

Norris's fears proved well-founded as officials in Britain proposed minimizing colonial autonomy. Lord Bath, for example, outlined a plan to Newcastle in December of 1757 whereby the independent

${ }^{57}$ Hershberger, "Pacifism and the State," 61.

${ }^{58}$ Gordon to Newcastle, November 11, 1757, in Newcastle Papers (hereafter NP), 32875, British Library (hereafter BL), London.

${ }^{59}$ Gordon to Newcastle, November 21, 1757 in ibid.

${ }^{60}$ Ibid.

${ }^{61}$ Norris to Charles, September 22, 1756 in INL, 1154, HSP. 
North American and Caribbean colonies would be forged into a federal union more closely supervised by Britain. In this proposed entity, Britain would tax the colonies to support a unified military establishment. Newcastle's informant, Gordon, concurred a month later, suggesting the posting of substantial military forces in North America for both defense and the regulation of the empire's colonial subjects. Under both proposals, the colonists would be directly responsible for supporting this significant military presence. ${ }^{62}$

As a consequence of such concern about the state of Britain's North American colonies, the agents sent by both Pennsylvania's proprietary and popular factions should have found a receptive audience within some part of the British government for their intervention requests. Instead, the agents encountered an imperial system paralyzed by a general lack of clarity about which entity had the authority to deal directly with the colonies, internal concerns about the exact relationship between Crown and proprietary prerogatives, and a set of British political factions that differed markedly about the importance of the colonies to the mother country.

The inability of Great Britain to clearly delineate an entity having direct authority over the colonies proved a serious impediment to any resolution of the Pennsylvania dispute. The Board of Trade had traditionally held preeminence in colonial affairs in the early Atlantic British Empire. In the first half of the eighteenth century, however, individuals such as Sir Robert Walpole managed to consolidate increasing power into the hands of the King's ministers. With regard to the colonies, this consolidation came at the expense of the Board of Trade. In the Cabinet, a collection of offices designed to directly assist the monarch in ruling Britain, colonial affairs technically fell under the jurisdiction of the Secretary of State for the Southern Department. The Southern Department also included oversight of the nation's interests in eastern and southern Europe, thus reducing the secretary's responsiveness to colonial

\footnotetext{
${ }^{62}$ Bath to Newcastle, December 11, 1757 in NP, 32876, BL; G. Gordon to Newcastle, November 19, 1757 in NP, 32876, BL.
} 
affairs. Despite this stated responsibility, moreover, near absolute ministerial power, including that over the colonies, might be wielded from any of the ministerial offices if a single individual managed to dominate his colleagues as Walpole managed to do. By the 1750s, Lord Halifax as the head of the Board of Trade had partially reversed the trend and regained some of the Board's prior preeminence. ${ }^{63}$ In 1753, an abortive move made by the Ministry clearly illustrates the complicated and inefficient design of the governments control over its colonies. Recognizing the incompatibility of the Secretary of State of the Southern Departments diverse responsibilities, the Ministry proposed the creation of a new office. Entitled Secretary of State for Plantation Affairs, the ministers intended it to manage the colonies directly. The Cabinet ultimately dismissed this rather logical proposal because it found itself unsure about how the new office might conflict with the prerogatives of the Board of Trade which had been given new authorities by the Crown in 1752 .

Within the various British departments charged with oversight of the colonies, confusion reigned as well. The Board of Trade found no difficulty in regulating issues of commerce between colonial and British merchants, but when it came to internal colonial affairs it acted much less decisively. In a 1756 inquiry about Pennsylvanian politics, members of the Board strongly recommended intervention. ${ }^{64}$ Just the year before, however, the Board had abandoned a move to reorganize Pennsylvania due to the unclear nature of the Board's authority over the proprietary province. "If the Line is to be drawn from any given Point at the North Eastern Extremity of the Apalachean Mountains to any part of the Lake Ontario," Lord Halifax reported, "[i]t will be yielding up near one Third of the Province of Pensylvania, as an uninhabitable Country; \& it is worthy Consideration \& Enquiry, what Townships \& settlements may be broken up by such an Agreement-How far It may trespass upon the

${ }^{63}$ See Williams, Oxford History of England.

${ }^{64}$ James Abercromby to Francis Faquier, July 20, 1758 in George Reese ed., The Official Papers of Frances Fauquier: Lieutenant Governor of Virginia, 1758-1768, 3 Vols., Charlottesville, VA: The University Press of Virginia, 1980, 1:53-54; Schwartz, "Mixed Multitude," 218-219. 
Right of the proprietors of this Province; \& how far It may be legal, just, or proper, in the Crown to attempt it." ${ }^{65}$ Nor did the Ministry prove more decisive in its actions towards Pennsylvania and the other North American colonies.

As the Seven Years' War erupted, the Cabinet took an interest in the military situation of its colonies. Even as tensions developed, Whitehall had warned Pennsylvania of an impending conflict and had instructed it to prepare to repel any French attacks. Although the province ignored these instructions until after the outbreak of hostilities, British officials in the Ministry continued to review the colony's military preparations. It gathered intelligence about the first militia elections in late 1755 and ultimately attempted to invalidate those elections under the pretense that the first Militia Act proved too independent of higher provincial authorities, namely the proprietary governor. ${ }^{66}$ Like the Board of Trade, however, the Ministry proved unsure of its authority to act in such ways. In October of 1757, the Cabinet informed the King that it had determined the necessity of commissioning an officer to be "commander in chief of Home and in america." ${ }^{67}$ Although the government had previously sent officers to command in America, and although they wielded royal authority over the colonies, none had possessed a title so starkly demonstrating the secondary status of the colonies in relation to London. As a consequence, the primary ministers to George II fretted and debated among themselves the propriety of such an action. "Lord Mansfield made strong objection to the Insertion of america in Ligonier's Commission. That It was absurd," Newcastle reported, "that, in the ticklish situation of the colonies, nobody could tell what Effect, It might have over them, If an officer in England, and residing constantly here, was to have the supreme command over them. ${ }^{168}$ While the Ministry struggled to determine how

\footnotetext{
${ }^{65}$ Lord Halifax's Observations on Thos. Robinson's Paper of Points, February 1755 in Papers Relating to North America (hereafter PRNA), Vol. 2, 33029, British Library, London.

${ }^{66}$ Schwartz, "William Penn and Toleration,"; Accounts from Pennsylvania, December 25, 1755 in PRNA, 33029, BL; Stephenson, "Pennsylvania Provincial Soldiers," 202.

${ }^{67}$ Memorial for the King, October 191757 in NP, 32875, BL.

${ }^{68}$ Newcastle to Hardwicke, October 23, 1757 in ibid.
} 
it should deal with the colonies during the conflict, heightened factionalism within Whitehall further impeded its ability to effectively act.

Agents from Pennsylvania found a political divide in Great Britain that made it difficult to produce favorable responses to their petitions. Whig politicians represented one end of the spectrum and at their core strongly supported the prerogative of the monarchy. The Whigs also favored strong Continental alliances to protect King George II's beloved homeland of Hanover, a German principality over which he still served as Elector. The Whigs had dominated British politics since Walpole established the so-called Whig Supremacy in the 1720s.

On the other side, those who differed from these policies, but wished to avoid the political suicide of leaving the Whigs, went into opposition and were given the appropriate moniker of Opposition Whigs. Some of these individuals actually associated closely with the Tory policy of country, or patriot, politics. These politicians generally wished to diminish royal prerogatives and specifically sought to block what they believed was George II's subrogation of English interests to those of Hanover. They consequently opposed a strong standing army because it cost British taxpayers dearly and was, opponents argued, clearly designed to be employed in defense of the King's interests in Hanover. The island nation needed no such standing army for its defense, Opposition Whigs argued, and the only other use of the peacetime force might be as a tool of oppression. Instead, they believed that a free populace could, and should, demonstrate its virtue and thus right to liberty by defending themselves. Such a belief manifested itself in late 1757 during Pitt's spirited defense of an ultimately successful militia bill that allowed for the mobilization of a citizen soldiery under popularly-elected officers. The Tory's, and some Opposition Whigs, also rejected the Whig support for strong Continental connections, believing them to be driven by the King's commitment to Hanover. They alternatively favored the use of the Royal Navy in a 'blue water strategy' that sought to expand Britain's imperial and economic interests abroad to the advantage, they argued, of all. 
Both 'parties', if they can be called that, sincerely lamented the growth of the national debt as the Seven Years' War expanded, but they predictably differed on where government investments should be made. The Whigs believed that financial investments on the Continent were valuable in maintaining Britain's interest in Europe. The Tories and some Opposition Whigs, on the other hand, backed global financial investments. By late 1757 , as proprietary and popular faction hostilities reached fever pitch over the funding of Pennsylvania's militia, the Ministry became neatly divided between these two factions. Despite this division, the Duke of Newcastle, representing the Whigs, and William Pitt, representing the opposition Whigs, forged a workable administration that ultimately proved capable of directing the nation through the conflict. Yet the competing interests of these two men, and the political interests that backed them, virtually ensured that no serious consideration of Pennsylvanian issues would be undertaken. For Pennsylvanian politicians, many past the point of compromise, this lack of attention proved troubling. ${ }^{69}$

${ }^{69}$ Older histories tend to portray Pitt as an all-encompassing political figure. Walford Davis Green's William Pitt, Earl of Chatham, and the Growth and Division of the British Empire, 1708-1778 attributes Britain's success in the Seven Years' War to Pitt's policies, his refusal to acknowledge the fractured nature of the Ministry and the power reserved to other members, most significantly Newcastle. Published in 1901, this pre-Churchillian history promotes Pitt as the epitome of a wartime leader. Indeed some contemporaries, likely supporters of Pitt, believed this to be the case. In at least one pamphlet, an anonymous 'Person of Distinction' noted that Pitt had "been the principal contriver" of recent successes. According to historian Jeremy Black, however, such treatment of Pitt represents the work of "later apologists who needed a heroic figure to personalize the rise of Britain to imperial greatness." The remainder of the twentieth century has been less accepting of Pitt's preeminence. Black continues his assessment, noting "Pitt has been returned by recent scholarship to a context of contention and complexity." Historian Richard Middleton perhaps treats Pitt most negatively. Believing Pitt's role to have been grossly overstated, the author's Bells of Victory: The Pitt-Newcastle Ministry and the Conduct of the Seven Years' War, 1757-1762 attempts to return the Duke of Newcastle to a place of prominence within the Ministry. Lawrence Henry Gipson's monumental The Great War for Empire, while praising Pitt, conversely attributes much of Britain's success to Newcastle's crippling of the French merchant marine in the previous administration. Although such works remain valuable in questioning the mythical treatment of Pitt, many recent scholars continue to embrace the preeminence of Pitt during the years of Britain's victories. Rather than a leader who possessed absolute control of the Ministry, as Green might suggest, such authors suggest Pitt managed to effectively control the Cabinet while remaining only one of its leaders. Marie Peters, in Pitt and Popularity: The Patriot Minister and London Opinion during the Seven Years' War, contends that Pitt's "strength came rather from the psychological impact of his personality, his ability to dominate his Cabinet colleagues, to inspire the confidence - or fear-of individuals and the devotion of the nation." Basil Williams would concur, noting that shared authority within the Ministry would have been problematic had Pitt not been able to dominate his colleagues. Specifically, the author 
Had they closely engaged the issues, Newcastle's Whig allies would have philosophically sympathized with the proprietary faction in Pennsylvania. If men such as Glen, Gordon, and Bath lamented the turbulence of Britain's New World colonies and the unruly nature of their inhabitants, elite proxies such as Pennsylvania's proprietors and their supporters appeared to be a suitably indirect source of societal control. Because the proprietary faction resented the unruly behavior of Pennsylvanians as well, they could be depended upon to uphold order with policies somewhat consistent with the political ideologies of Whigs in Britain. If effective as a proxy, moreover, stability created by the proprietary faction would allow the Whigs to focus on European affairs and pay scant attention to America, as they generally preferred to do. Despite this apparent compatibility of interest, the Newcastle-led Whigs failed to embrace the opportunity presented and instead remained almost entirely focused on European issues during the critical years encompassed by the Seven Years' War. Instead of dealing with the proprietary party, the Duke and his allies engaged themselves almost entirely with raising funds for the war and pursuing diplomatic alliances with Spain, the Netherlands, and various

\section{German states.}

notes that the pliable Lord Holdernesse, Secretary of State of the Northern Department and described as a glorified clerk to Pitt, helped neutralize the machinations of Newcastle. Finally, O.A. Sherrard's Lord Chatham: Pitt and the Seven Years' War provides perhaps the most convincing argument pertaining to the strength of Pitt's position in the Ministry. According to the author, Pitt produced the plan for North American operations over the Christmas holiday in 1757. Newcastle, asked by Pitt to be present, declined to assist due to his plans to host the Bishop of Durham at his Claremont estate. Thus, Pitt himself officially produced the plans for North American affairs in 1758 with subsequent concurrence from Newcastle. Thus, most historians now acknowledge that the power within the Ministry proved relatively divided between the two men and their supporters. Newcastle possessed significant support in the House of Lords and with the King himself, whereas Pitt held sway in the House of Commons and with the general British public. Neither, however, possessed enough influence to completely trump the other and compromise subsequently reigned. See Person of Distinction, A Genuine Narrative of the Enterprize Against the Stores and Shipping at St. Maloes, from the Letters of a Person of Distinction in the Service (London: Printed for J. Staples, 1758), vi. Accessed in Eighteenth Century Collections Online, March 14, 2010. Black, Pitt the Elder, xiii; Middleton, The Bells of Victory, 154; Gipson, Great War for the Empire, 6:425-426; Peters, Pitt and Popularity, 29; Williams, Life of William Pitt,325-327; Sherrard, Lord Chatham, 254-255. Sherrard does indicate that Pitt's actions may have been political maneuvering in an attempt to produce the plans when he knew Newcastle would be unavailable. The timing may also simply reflect his penchant for hard work. The orders produced by Pitt were issued on December 30, 1757 and may be found in Gertrude Selwyn Kimball ed., Correspondence of William Pitt When Secretary of State with Colonial Governors and Military and Naval Commissioners in America, 2 volumes (New York: The MacMillan Company, 1906), 1:133-155. 
By May of 1758, the British public had become alarmed at the astronomical costs associated with continuing the Seven Years' War and a concurrent rise in prices for everyday items made such concerns tangible for many. The House of Commons officially voted to raise five million pounds for operations in 1758 but subsidiary expenses made the total committed for the year much higher. To minimize the public's displeasure, allies of Newcastle conducted accounting sleight of hand to hide many of these extra expenses from the taxpayers. Despite the Opposition Whig's distaste for public debt, Pitt actively supported these expenditures and had convinced Commons to vote for them despite the palpable public pressure not to do so. Newcastle and the Secretary, however, consistently disagreed on how to dispense the funds. ${ }^{70}$

To raise the necessary finances, Great Britain, similar to its Continental contemporaries, attempted to increase taxes. Due to the public antipathy towards the cost of the conflict, however, the type and amount of taxes to be raised became a heated political issue. After being advised that taxes "should be made Equal," Newcastle largely attempted to pursue rather progressive tax measures. ${ }^{71}$ The Duke explored many different possibilities including a sugar and stamp tax, a window tax that would charge citizens a fee per window in their home and business, a poll tax, and an officeholding and pension measure. The latter proved particularly troubling when an advisor pointed out that many officeholders made their principle incomes not from salaries but from benefiting unofficially from their positions. A tax on public salaries would thus not affect elite officeholders proportionally. The Whigs ultimately feared that their political opponents, equally aware of this reality, would use this to stir up increased public resentment at the dominant faction. ${ }^{72}$ To diminish the need for taxes, the Ministry

\footnotetext{
${ }^{70}$ Newcastle to Yorke, January 31, 1758; Newcastle to Hardwicke, January 21, 1758 in NP, BL, 32877; West to Newcastle, ND; Legge to Newcastle, March 31, 1758 in NP, BL, 32878; Chesterfield to Newcastle, May 4, 1758, Nugent to Newcastle, April 4, 1758; West to Newcastle, April 22, 1758 in NP, BL, 32879.

${ }_{71}^{71}$ Page to Newcastle, ND, NP, BL, 32875.

${ }^{72}$ Hardinge to Newcastle, October 13, 1757 in NP, BL, 32875; Heads for a Letter to Mr. Legge, December 31, 1747 in NP, BL, 32876; West to Newcastle, April 28, 1758 in NP, BL, 32879.
} 
explored a variety of alternate means to raise funds including lotteries and an improbable scheme to strip unused lands from the monarchy and nobility to be sold at public auction. ${ }^{73}$

As the Seven Years' War broadened and became global in scope, Britain's primary rival in the conflict began to borrow enormous sums of money. To maintain parity with France, Britain came to rely heavily on public credit as well. Provided with proper economic motivations, Newcastle found little difficulty in finding willing lenders among private bond purchasers and more significantly with the banking centers in London. Economic profit alone, however, did not guarantee the monetary support of many of these lenders, for Newcastle came to recognize that philosophical views on how the war should be conducted played a significant role in the decisions of many to lend or to withhold funds. ${ }^{74 ~}$ "[N]o one knows better than your grace of what consequence ye support of our publick credit is," one advisor reminded Newcastle, " $\&$ that it's chief support in ye opinion, \& confidence, that people repose in ye government, everything should be avoided to Lesson this confidence." ${ }^{75}$ The government attempted to build this confidence through successful management of the war, but lenders possessed personal views about how it should be waged. Newcastle's principle confidant, Lord Hardwicke, identified the reality succinctly. "I fear our new Friends [presumably Pitt and his allies] have promis'd the Country Gentlemen that no such Thing [sending troops to Europe rather than America] shall be," he noted, "\& That may be part of the Terms of their agreeing to give the money." ${ }^{76}$ Newcastle's official position as the First Lord of the Treasury thus placed him in an extremely difficult position with regards to the Pennsylvanian petitioners that had begun to cast about London for support in their domestic struggle. Unable to raise the necessary funds to wage war through taxes or alternate means, necessity compelled the Duke to borrow the funds. Because many of the lenders opposed his politics, he felt unable to advance his views

${ }^{73}$ Scheme for raising Four Millions for the year 1758, ND in NP, BL, 32876; Philo Patria to Newcastle, March 1758 in NP, BL 32878.

${ }^{74}$ Intelligence, November 21, 1757 in NP, BL, 32875; Bath to Newcastle, December 4, 1757; Newcastle to Page, November 26, 1757 in NP, BL, 32876; Legge to Newcastle, August 9, 1758 in NP, BL, 32882.

${ }^{75}$ Joseph Watkins to Newcastle, April 5, 1758 in NP, BL, 32879.

${ }^{76}$ Hardwicke to Newcastle, January 29, 1758 in NP, BL, 32877. 
for fear of alienating them. Thus, even if Newcastle and his allies did favor the proprietary faction, they could not disrupt the status quo and jeopardize the continued flow of borrowed funds into the government's coffers. ${ }^{77}$

Continental diplomacy with the Spanish, Dutch, and several German states also dictated the politics of the Whigs during the Seven Years' War. Although a 'diplomatic revolution' had occurred in securing an alliance with Prussia, it came at the expense of Britain's long-standing relationship with Austria. The new alliance subsequently drove that Catholic empire into the arms of France. Britain consequently found itself confronting France, Austria, Sweden, and Russia with only Prussia and the tepid assistance of Hanover and Hesse. Confronted with such odds, and principally concerned with Continental affairs, Newcastle and his allies desperately sought favor with the Spanish and Dutch while attempting to hold their fragile German alliance together.

On August 23, 1757, William Pitt informed his ambassador to Spain, Sir Benjamin Keene, that "Their Lordships are most humbly of opinion, that nothing can so effectually tend, in the present unhappy circumstances, to the restoration of Europe, in general, and in particular to the successful prosecution of the present just and necessary war, until a peace can be made on safe and honorable terms, as a more intimate union with the Crown of Spain." ${ }^{78}$ Pitt's letter to Keene represents a rare moment of agreement between his faction and that of Newcastle. Both favored such an alliance, but for drastically differing reasons. Pitt hoped Spain would tip the scales in Britain's favor in the Americas and additionally hoped that it might provide him an avenue to recover the island of Minorca. Lost to France in 1756, the island represented a strategic location critical to the protection of British trade in the Mediterranean. Although it may have technically been geographically 'European', its connection to commerce made it philosophically important to the Opposition Whigs and their Tory allies. For

\footnotetext{
${ }^{77}$ For a detailed discussion of Great Britain's financial policies, see John Brewer, The Sinews of Power: War, Money, and the English State, 1688-1783. Cambridge, MA: The Harvard University Press, 1990.

${ }^{78}$ Pitt to Sir Benjamin Keene, August 23, 1757 in NP, BL, 34412.
} 
Newcastle, however, an alliance with Spain would provide another Continental ally in Europe and would open up a newly hostile frontier for France.

While unlikely due to Spain's religious and familial connection to France, an alliance between Great Britain and Spain did not appear impossible. According to Keene and his successor as ambassador, the Earl of Bristol, Spain possessed four Secretaries of State who varied greatly in their opinions, varying from outright hostility to Britain to an aversion of France. Both men clearly indicated that Britain might convince a reluctant Spain to join its cause if they could smooth over tensions that had developed between the nations in the Americas. During the 1740s, when Britain and Spain had last fought, British colonists had begun illegally extracting timber from the Mosquito Shore in what is now Central America. To make matters worse, British colonial vessels on their way to and from the Shore occasionally practiced privateering against Spanish shipping. ${ }^{79}$ In an attempt to clear the Shore of British poachers in 1754, the Spanish subjected a captured Briton to a "hard fate" because he had been implicated in recent privateering. ${ }^{80}$ Finally, the Spanish demanded the right to access the fisheries off Newfoundland based upon claims of discovery from the seventeenth century. ${ }^{81}$ Inflaming tensions with Spain, the Board of Trade explicitly stated "the Impossibility of granting a Privilege which is expressly prohibited to all aliens \& strangers." ${ }^{82}$ Instead, the Board graciously offered Spain the opportunity to purchase fish from Great Britain. The Pennsylvanian petitioners presented Newcastle with a golden opportunity. While the popular faction might have viewed any type of restriction from Great Britain as an attack on their liberty, something they routinely accused their opponents of doing, the proprietary faction might have accepted some restrictions in exchange for support from the Ministry. Newcastle thus might have thrown his support behind the proprietors in exchange for promises that they would

\footnotetext{
${ }^{79}$ Earl of Bristol to Pitt, September 28, 1758 in Holdernesse Papers (hereafter HP), BL, MSS E6; Pitt to Newcastle, March 16, 1758 in NP, BL, 32878; Gordon to Newcastle, April 5, 1758; Lord Bristol to Newcastle, April 26, 1758 in NP, BL, 32879; Wall to Abreu, July 31, 1758 in NP, BL, 32882.

${ }^{80}$ Extract of a Letter from Bristol, December 16, 1754 in PRNA, BL, 33029.

${ }^{81}$ Abreu to Pitt, June 16, 1758 in NP, BL, 32882.

${ }^{82}$ Pitt to Bristol, August 1, 1758 in NP, BL, 32882.
} 
curb the illicit practices of timber poaching in Spanish territory and privateering against Spanish vessels. Pennsylvania, of course, was only one of Britain's American colonies, but such an agreement with Pennsylvania would prove to Spain Britain's intention of taking action to remedy the tensions between the two nations. Instead, Newcastle entirely ignored American affairs and proposed a European solution to an American problem. Against the suggestions of Keene, who declared it a 'family affair', Newcastle entertained ideas of seizing Sicily to trade to Spain in exchange for the nation's support. ${ }^{83}$

Unlike Spain, the Netherlands represented a much more probable addition to Britain's short list of Continental allies. Connected by religion, royal family, and to a certain extent demographics, the Dutch populace appeared largely in favor of joining the war against France. ${ }^{84}$ According to a British informant residing in France, that nation's leaders worried that Holland might "at last, be obliged, by the Populace, to enter into the War." 85 The Dutch monarchy also resented France, believing that British efforts amounted to the "saving her \& her family from the yoke of France." ${ }^{86}$ In addition, the Dutch military recruited heavily in Scotland and was thus likely to possess a greater affection for alliance with Britain over France. ${ }^{87}$

In 1758, support for Britain reached such a fever pitch that riots broke out in Amsterdam. Joseph Yorke, principle British representative in the city and son of Lord Hardwicke, reported that the people did so because they believed they had been "sold to France, that their magistrates suffer' $d$ the Kings of England \& Prussia to be opprest, \& that the merchants did nothing but carry on the French Trade." ${ }^{88}$ Indeed, the commercial interests in Amsterdam traded with the French and loaned money to both France and Austria as those two nations warred against Great Britain and her allies. While such

${ }^{83}$ Benjamin Keene to Pitt, September 26, 1757 in NP, BL, 34412; Felice Frederick to Newcastle, October 19, 1757 in NP, BL, 32875.

${ }^{84}$ Yorke to Newcastle, January 6, 1758 in NP, BL, 32877.

${ }^{85}$ Intelligence, November 30, 1757 in NP, BL, 32876.

${ }^{86}$ Yorke to Newcastle, November 29, 1757 in NP, BL, 32876.

${ }^{87}$ Barrington to Pitt, January 14, 1757; Pitt to Barrington, January 15, 1757 in HP, BL, E6.

${ }^{88}$ Yorke to Newcastle, July 28, 1758 in NP, BL, 32882. 
actions inevitably led to mistrust about the merchants' incentives for opposing war with France, their motivations proved much deeper than making a quick buck. ${ }^{89}$ According to Yorke, "arguments drawn from our mutual Interests of Religion \& Liberty are mere words, \& treated as such, the Interest of their Commerce ... [is] substituted in their place." " "[T]he fury of the Trading People," as Yorke termed it, resulted from both long-standing and newly emerging tensions. ${ }^{91}$ According to the diplomat, Dutch merchants still maintained a grudge about certain terms included in the Treaty of Westminster which had ended the Third Anglo-Dutch War. Although the treaty certainly did not favor Britain, it had wrested certain concessions from the Dutch including relinquishment to any claims to New Netherlands and had ensured mutual access to the spice trade in the East Indies. Because the Dutch probably recognized the improbability of the British returning the North American territories after so many years and the region's shift towards a more Anglo population, opposition to the treaty likely represented a desire to secure exclusive control in the East Indies. The merchants also demanded British protection in the West Indies. If the Dutch entered the war against the French, they would need this protection. Or, if an illicit trade continued with the French even after an alliance with Britain was established, the Dutch could nearly guarantee the safety of its vessels. This ongoing trade with the French created the final impasse blocking an Anglo-Dutch agreement. In an attempt to damage the French war effort, the British enacted a policy that allowed the seizure of Dutch vessels intending to trade with France. This infuriated Dutch merchants who in turn demanded the release of impounded ships and financial restitution for any losses. ${ }^{92}$

Similar to their policies towards Spain, the Whigs pursued decidedly European policies to solve a global issue. In August of 1758, Hardwicke noted his belief that no mercantile agreement would be

${ }^{89}$ Extract of a Letter from Amsterdam, February 1, 1758 in NP, BL, 32877; Yorke to Newcastle, August 4, 1758 in NP, BL, 32882.

${ }^{90}$ Yorke to Newcastle, January 27, 1758 in NP, BL, 32877.

${ }^{91}$ Yorke to Newcastle, July 21, 1758 in NP, BL, 32882.

${ }^{92}$ Yorke to Newcastle, July 4, 1758; Newcastle to Yorke, July 19, 1758 in NP, BL, 32881; Yorke to Newcastle, August 15, 1758; Yorke to Newcastle, August 8, 1758 in NP, BL, 32882. 
reached with the Netherlands because of "a Backwardness \& Disinclination in a great part of the Administration here, to meddle in those matters." ${ }^{93}$ Much of that "Backwardness \& Disinclination" can be attributed to Newcastle. The January before Hardwicke's observation, Newcastle mused to Yorke that Holland must be made afraid of France before any alliance might be formed. Presumably, that fear would force the Dutch to rely on British and Prussian arms to ensure their survival against any onslaught by the numerically superior French military. To buttress this strategy, the Duke informed Lord Anson, head of the navy, that he had permission to treat the Dutch poorly on the high seas as a reminder that the British might be worthy of fear as well. By developing such a 'system', as he liked to call it, the minister grossly misunderstood Dutch priorities. He exacerbated tensions between the two nations by encouraging Anson to unleash the Royal Navy on Dutch shipping while relying on religious, familial, and ideological connections to outweigh these concerns in the Netherlands. By projecting his Continental focus on the Dutch, Newcastle missed the opportunity to address the merchants' concerns about their global trade. As had been the case with Spain, a deal with a Pennsylvanian faction might have included a favorable trade agreement with the Netherlands, promises of protection from Pennsylvanian vesselsanything, as minimal as it might have been, that would indicate to the Dutch merchants that the Ministry recognized their priorities. ${ }^{94}$

Newcastle's tendency to view tensions in European terms reflects his and his allies' commitment to Continental affairs before all else, including referring to himself as a "continent Politician" to differentiate himself from his political opponents. ${ }^{95}$ This commitment derived from his firm belief that only in Europe could the war be decided. "For, except we can divert the Power \& Force of France, by Measures upon the Continent," he argued, "all our other Attempts, by Expeditions on their Coasts, and

${ }^{93}$ Hardwicke to Newcastle, August 4, 1758 in NP, BL, 32882.

${ }^{94}$ Yorke to Newcastle, ND in NP, BL, 32876; Newcastle to Yorke, January 17, 1758 in NP, BL, 32877; Newcastle to Anson, March 26, 1758 in NP, BL, 32878; Newcastle to Hardwicke, April 26, 1758 in NP, BL, 32879; Yorke to Newcastle, July 14, 1758 in NP, BL, 32881.

${ }^{95}$ Newcastle to Anson, July 7, 1758 in NP, BL, 32881. 
most Expensive operations, in Both Indies, \& in North America, will turn upon us, \& signify Nothing, \& prove a most useless Expence." ${ }^{96}$ Newcastle's informant in France indicated that French leaders held a similar view. "This Resolution [referring to the French decision not to seriously attempt to challenge the British Royal Navy], in some measure, changes the Nature of the war, \& therefore deserves the attention of your court;" he informed Newcastle, "[f]or if we can ruin all your allies in the [Holy Roman] Empire, \& take Possession of Their Dominions; your nation will at last be forced to consent to a Peace, on such Terms as France will dictate, notwithstanding your being masters at sea, or the Progress your arms may have made in America." ${ }^{97}$ To Newcastle, the course Britain should take appeared indisputable, and he sincerely hoped that "[t]he Continent will become a Favorite" with fellow politicians and the public at large. ${ }^{98}$ If the broader strategic concerns eluded them, he framed it in terms valued by the public and his Opposition Whig antagonists. "It is our Business and That of Every Free State," he declared, "who has the least concern for Their own Liberties, and those of Europe" to support engagement in Germany in defense of "[t]he Protestant cause, \& Liberties of Europe." 99 Thus framing what he believed to be a necessary commitment in religious and ideological terminology dear to his countrymen, the Duke hoped to provide substantial support for Britain's only Continental alliesHanover, Hesse, and Prussia.

As hostilities broke out between Britain and France, George II dispatched his favorite son, William Augustus, the Duke of Cumberland to command the Army of Observation in Hanover. His German troops beaten badly by the French in battle, Cumberland negotiated the Convention of Klosterzeven where he agreed to disband the majority of his army and left much of Hanover occupied by the French. The agreement sent shockwaves throughout Whig political circles because it left George's

\footnotetext{
${ }^{96}$ Newcastle to White, July 29, 1758 in NP, BL, 32882.

${ }^{97}$ Intelligence, July 30,1758 in ibid.

${ }^{98}$ Newcastle to Yorke, November 22, 1757 in NP, BL in 32876.

${ }^{99}$ Ibid.
} 
boyhood and ancestral home occupied by the French and seriously threatened Britain's emerging alliance with Prussia. Literally fighting for its life against threats from Sweden, Russia, and Austria, the Prussians desperately needed a force in Hanover to act as a defensive shield against any French attempt to advance against them. For 'continental politicians' such as Newcastle, it became imperative to reestablish a military force in Hanover that could act as that shield. ${ }^{100}$

The agreement made by Cumberland, Newcastle claimed, "is now the chief Discourse, not only of this country; but, almost, of every other."101 Indeed, Spanish diplomats referred to it as 'shameful' and Britain's next move appeared destined to dictate its reputation with European nations. Although George II had given his son permission to negotiate as events turned against him, the intactness of the German forces commanded by Cumberland tempted the King and his Continentally-minded ministers to question the ramifications of refuting the terms dictated at Klosterzeven. Their desire to assist Prussia, and likely to save face, led them to increasingly push for aggressive British action in Hanover.

Ultimately, a disgraced Cumberland resigned his military position leading to Britain entrusting command of a reactivated Army of Observation, now renamed the Army of Execution, to Ferdinand of Brunswick. To encourage continued support from the German allies, principally Hanover and Hesse, Britain assumed the vast majority of the expense. ${ }^{102}$

Outside of the monarchy and Whig politicians, support for a commitment to Hanover proved underwhelming. To a large degree, many Briton's mistrusted the leadership in Hanover. As the military requested increase after increase in support, many came to believe that no sum would ever satisfy their apparently insatiable demands. Some came to suspect that the government pocketed portions of funds intended for the military establishment. One individual even believed that only thirty thousand men

\footnotetext{
${ }^{100}$ Chesterfield to Newcastle, October 13, 1757 in NP, BL, 32875.

101 Newcastle to Chesterfield, October 13, 1757 in ibid.

${ }^{102}$ Abreu to Grimaldy, October 18, 1757; Holdernesse to Mitchell, October 14, 1757; West to Newcastle,
} July 26, 1758; Newcastle to Holdernesse, August 11, 1758 in NP, BL, 32882. 
had been raised with the British subsidy where fifty thousand had been the expectation. Some assumed that this resulted from unscrupulous Hanoverian contractors who dishonestly lied about prices for items needed in support of the army. To rectify this problem, some opponents of support for the electorate demanded the dispatch of English contractors to the Continent to actually handle British funds. A belief that Ferdinand refused to engage in action seemed proof to many that Hanover was, quite shockingly, more concerned with its own interests than those of Britain. ${ }^{103}$ The British people also questioned the motives of their own sovereign. "His Majesty has, in the most gracious manner, condescended to communicate to His English Servants; who, Tho' They did not dare to presume to offer Their humble advice to The affairs of His Electorate," Lord Holderness, Secretary of State of the Northern Department observed, "yet They thought It Their Duty to lay at His Majesty's Feet Their opinion, as to the support, England ought to give The King." ${ }^{104}$ Indeed, behind the scenes Newcastle maneuvered to support the monarchy's interests in Hanover. "My present scheme is . . not to remain in Bussiness," Newcastle at one point concluded, but to do "upon going out, or afterwards the utmost I can To serve The King, in any reasonable scheme, That may be proposed for the Defence, or security of His german Dominions." 105 Public outrage might have reached a fever pitch had the full extent of the monarchy's support of its German territories been exposed. At the time, Ferdinand of Brunswick and the Duchess Dowager of Brunswick each received a two thousand pound per year pension, the Princess of Hesse, daughter of George II, a five thousand pound per year payment, and a cumulative five hundred extra pounds a year went to assorted other individuals - all on the British taxpayers' dime. ${ }^{106}$ William Pitt accurately

${ }^{103}$ Newcastle to Yorke, October 25, 1758; Newcastle to Hardwicke, October 27, 1757 in NP, BL 32875; Newcastle to Yorke, December 6, 1757 in NP, BL, 32876; West to Newcastle, January 20, 1758 in NP, BL, 32877 ; Newcastle to Stone, March 4, 1758, Newcastle to Pitt, March 17, 1758, Hardwicke to Newcastle March 24, 1758, Newcastle to Hardwicke, March 25, 1758, Newcastle to Pitt, April 5, 1758 in NP, BL, 32878; West to Newcastle, April 1, 1758; Memorial for the King, April 11, 1758 in NP, BL, 32879; Newcastle to Chesterfield, June 10, 1758 in BL, NP, 32880; Newcastle to Yorke, August 11, 1758 in NP, BL, 32882.

${ }^{104}$ Holderness to Mitchell, October 10, 1757 in NP, BL, 32875.

${ }^{105}$ Newcastle to Hardwicke, February 12, 1758 in NP, BL, 32877.

${ }^{106}$ Newcastle to Bedford, July 21, 1758 in NP, BL, 32882. 
condensed the philosophical problem many Briton's had with the support Britain gave Hanover. "I must leave it to your grace to judge, if this be a just return for the generosity of the Publick disposition, or the way to preserve the continuance of it, and carry us thro' the war permit me to observe, that every discussion this insatiable service has undergone, your grace has suffered the demand to swell in a manner beyond all decency," he informed Newcastle. "Pardon the freedom," Pitt continued, "but I owe it to your grace, to myself, and an ill-requited Country."107

While many Britons frowned upon support for Hanover due to suspicions of intrigue, their perception of Prussia differed significantly. Many considered the nation an honorable defender of liberty and Protestantism and its King, Frederick II, won widespread, if temporary, celebrity status. Because of these perceptions, no similar distrust and suspicion developed but the increasingly heavy burden of subsidies did elicit unrest. Food and forage alone for Prussia cost Britain $£ 120,000$ per month, and other provisions brought the total to more than four million pounds per year. Newcastle pointed out to his principal diplomat to Frederick, Mr. Mitchell, that this represented the single largest subsidy Britain had ever provided to an ally. ${ }^{108}$ Pitt referred to it as a "mountain of expense" and to avoid that negative connotation with the taxpayers, Hardwicke advised Newcastle to publically use the word 'support' rather than 'supply' when publicly speaking about the subsidies. ${ }^{109}$

Support for Prussian subsidies further eroded when it became apparent that Frederick demanded further assistance. As much as Prussia relied upon the subsidies to continue the conflict, Frederick ultimately desired "some measure may be practicable for England, to divert the attention of

${ }^{107}$ Pitt to Newcastle, April 4, 1758 in NP, BL, 32879.

${ }^{108}$ Memorandom, September 22, 1758 in HP, BL, EG; Page to Newcastle, November, 29, 1757, Newcastle to Mitchell, Decmber 8, 1757, Newcastle to Yorke, December 16, 1757; West to Newcastle, December 24, 1757 in NP, BL, 32876; Lord Stormont to Newcastle, February 8, 1758 in NP, BL, 32877; West to Newcastle, March 13, 1758; John Luke Nicholl to Newcastle March 24, 1758 in NP, BL, 32878; Yorke to Hardwicke, July 31, 1758 in NP, BL, 32882. BL, 32875.

${ }^{109}$ Pitt to Newcastle, March 6, 1758 in NP, BL, 32878; Hardwicke to Newcastle, November 1, 1757 in NP, 
some of his Enemies."110 The Prussian Monarch principally desired two actions-the dispatch of a British fleet to the Baltic to defend his northern frontiers from the Swedes and Russians and an influx of English troops to bolster German forces fighting a four-front conflict. No one on any side of Britain's political spectrum seriously considered sending a fleet to the Baltic Sea. Already stretched thin defending the home islands and global trade, the Royal Navy did not possess the strength to send a force sufficient to defeat the combined strength of Sweden and Russia. Both Newcastle and Pitt feared the effect such a defeat would have against what they considered second-rate naval powers. Other than protecting Prussia, Britain possessed no real strategic interest in the Baltic that might merit such a commitment. The call for troops, however, deeply divided the Ministry. Newcastle favored such a move because he considered it essential to maintain friendly relations with Prussia. ${ }^{111}$ Upon forming his Ministry with Pitt in late 1757, the British ambassador to Prussia reported that "[h]e [Frederick] expressed to me ... his hearty approbation of your Grace's returning again to the Helm, said He believed things would now go better than they had done, that He knew your Grace was a good friend and sincere, that He had the more confidence in your Grace." ${ }^{112}$ According to the diplomat, Frederick trusted Newcastle's leadership because he pursued "manly and vigorous measures." ${ }^{113}$ Beyond his ideological commitment to the Continent, the Duke pursued favorable policies towards Prussia because he believed that the embattled monarch might abandon Britain without proper support beyond the subsidies. Mitchell frequently reported the King's displeasure that Britain did not get more actively involved and further suggested that France had secretly made overtures for a separate peace.

${ }^{110}$ Yorke to Newcastle, February 17, 1758 in NP, BL, 32877.

${ }^{111}$ Holdernesse to Pitt, March 26, 1758 in HP, BL, E6; Mitchell to Holderness, October 24, 1758; Mitchell to Newcastle November 11, 1758 in NP, BL, 32875; Yorke to Newcastle, February 7, 1758; Newcastle to Holdernesse, February 12, 1758 in NP, BL, 32877; Substance of Mr. Michell's Three Letters, February 22, 1758, Holdernesse to Pitt, March 26, 1758; Newcastle to Holdernesse, March 27, 1758 in NP, BL, 32878.

${ }^{112}$ Mitchell to Newcastle, October 15, 1757 in NP, BL, 32875.

${ }^{113}$ Mitchell to Newcastle, June 10, 1758 in NP, BL, 32880. 
Newcastle also faced personal demands just short of ultimatums from Prussian representatives, the Barons Kniphausen and Munchhausen. ${ }^{114}$

In the fall of 1757, Newcastle lamented his inability to fulfill the needs of Prussia. As he informed Mitchell in response to his repeated suggestions to send troops, "our scheme, or system [of subsidies], is the only one, that can be adopted in our present circumstances, we must make the best of it we can, whatever misfortunes may attended it." ${ }^{115}$ Believing that such a policy alone proved "[b]ase and shortsighted," the Duke proceeded to maneuver the nation towards committing troops on the Continent. ${ }^{116}$ To his principle confidant Hardwicke, the Duke reacted strongly, declaring "the single Inconvenience or Absurdity, arising from a Principle adopted, of supporting the Continent with Two Millions of Money, but no national Troops, should not prevent it."117 Unfortunately for Newcastle, political realities required the acquiescence of Pitt for any realistic hope of direct British intervention on the Continent. ${ }^{118}$ The Duke admitted his dependence to Lord Hardwicke while recounting a cabinet meeting with the Secretary. "Mr. Pitt asked Me afterwards ... whether I would avow the Measure of sending Two Battalions [to Germany]? I said, yes, if He would agree to it;" he reported, "[b]ut he said, suppose, He protested against it, as He did, I said, That was another Case." ${ }^{119}$

For Pitt, opposing the dispatch of troops to Germany flowed naturally because it represented a pillar of Tory and oppositional rhetoric. Combating the proposal fulfilled his faction's commitment to control public debt and not sacrifice British commercial concerns to Continental issues. Within the

${ }^{114}$ Mitchell to Holderness, December 25, 1757 in NP, BL, 32876; Mitchell to Newcastle, February 9, 1758 in NP, BL, 32877; Memorial for the King, March 14, 1758; Holdernesse to Newcastle in NP, BL, 32878; Mitchell to Newcastle, July 31, 1758 in NP, BL, 32882.

${ }^{115}$ Newcastle to Mitchell, December 23, 1757 in NP, BL, 32876.

${ }^{116}$ Pitt to Holdernesse, September 10, 1757 in HP, BL, E6.

${ }_{117}^{117}$ Newcastle to Hardwicke, January 29, 1758 in NP, BL, 32877.

${ }^{118}$ Devonshire to Holdernesse, November 29, 1758; Holdernesse to Pitt, May 11, 1758 in HP, BL, E6; Memorial for the King, December 22, 1757 in NP, BL, 32876; Newcastle to Pitt, March 24, 1758 in NP, BL, 32878; Newcastle to Hardwicke, April 2, 1758 in NP, BL, 32879; Holdernesse to Newcastle, May 11, 1758 in NP, BL, 32880; Hardwicke to Newcastle, July 4, 1758 in NP, BL, 32881.

${ }^{119}$ Newcastle to Pitt, August 2, 1758 in NP, BL, 32882. 
Ministry, the Secretary dismantled any attempts Newcastle made to promote such action by questioning the motives of Britain's primary diplomat to Prussia, Mr. Mitchell. Concerned, Pitt identified his problems with Mitchell to Newcastle:

Andrew Mitchel is not a fool, and therefore he must be something not fit to be the Instrument of the present system of administration in the vital and essential part of the Plan of Europe, your transactions with Prussia. I have long entertain'd a very indifferent opinion of his correspondence, from reasons too obvious to trouble your grace with, and I am now entirely convinced that he is mischievous, to a degree, that perhaps may already have rooted Ideas in the King of Prussia's mind, which will inevitably overturn the system. I see his aim is, (and I expect he will have succeeded in it,) to get the $\mathrm{K}$ of $\mathrm{P}$ : to propose British troops, as a Part of the Plan for the next campaign in Germany ... I do not intend for one, that Andrew Mitchel shall carry me where I have resolved not to go." ${ }^{120}$

Although Newcastle confided to Hardwicke that he doubted the Secretary's assertions, Pitt had clearly concluded that partisan politics had led Mitchell to fabricate his accounts of Frederick's demands for British action and to plant those very ideas in the King's mind. ${ }^{121}$ The diplomat undermined his position by voicing his opinion to the ministers that he supported a Prussian exit from the war if no direct British military arrived in 1758. In a letter perhaps realistically assessing the situation, yet dangerously ignoring the interests of Britain, Mitchell asked if "[t]he King of Prussia [could] be blamed if He should save Himself by submitting to France?"122 To combat the suspected machinations, Pitt proceeded to assume control of the cabinet's correspondence with the wayward diplomat. Because his department possessed no technical authority over affairs in Germany, Pitt bullied his counterpart, Secretary of State of the Northern Department, Lord Holdernesse, into asserting his will. "[M]y Drat to Mr Mitchell is

\footnotetext{
${ }^{120}$ Pitt to Newcastle, January 28, 1758 in NP, BL, 32877.

${ }^{121}$ Newcastle to Hardwicke, January 29, 1758 in ibid.

${ }^{122}$ Mitchell to Holdernesse, From Germany in Cypher, October 15, 1757 in NP, BL, 32875.
} 
mutilated [by Pitt] so as to be scarce legible even to myself," Holdernesse complained to Newcastle. "I would not pass such another evening for the King's revenue ... for I neither can nor will be detained for hours upon the introduction of a monosillable." ${ }^{123}$ Pitt, it seems, took his time in crafting his orders for Mitchell. Despite his direct intervention, the Secretary continued to distrust the diplomat. "[A]s to the Powers sent to Michel," he informed Holdernesse a month after their unpleasant evening together, "I can not say, as yet, that I am greatly satisfy'd by the nature and Tone of them."124 In fact, the Secretary had already bypassed his counterpart by appealing directly to George II for a recall of the diplomat, a position eventually parroted by Holdernesse a month later. An embattled Mitchell ultimately returned to Britain to meet directly with Pitt in a futile effort to defend his actions. To Newcastle's regret, Pitt effected the replacement of the diplomat. ${ }^{125}$

Beyond his antipathy towards and suspicion of Mitchell, Pitt opposed direct involvement on the Continent on a much more practical level-it remained extremely unpopular with the public. Newcastle's allies clearly recognized this reality but abjectly ignored it in pursuing what they thought represented the true interests of the nation. "I wish your grace joy of this good beginning of right measures," an ally of the Duke responded after hearing of the ultimate decision to support the Continent with troops, "at the risk (and certainly there is some risk) of popularity." ${ }^{126}$ In a sarcastic rebuke of Pitt's populist policies, Newcastle further confirmed the public's stance, noting to Hardwicke that "[t]he publick is much obliged to Him [Pitt], for taking such Care of their Revenues, $\&$ their interests." $^{127}$

${ }^{123}$ Holdernesse to Newcastle, February 25, 1758 in NP, BL, 32878.

${ }^{124}$ Pitt to Holdernesse, March 26, 1758 in HP, BL, E6.

${ }^{125}$ Holdernesse to Newcastle, March 15, 1758, Holderness to Pitt, March 25, 1758; Pitt to Holdernesse, March 26, 1758 in NP, BL, 32878; Newcastle to Hardwicke, April 22, 1758; Hardwicke to Newcastle, April 23, 1758 in NP, BL, 32879.

${ }^{126}$ Barrington to Newcastle, Jun 24, 1758 in NP, BL, 32881.

${ }^{127}$ Newcastle to Hardwicke, May 21, 1758 in NP, BL, 32880. 
While Pitt focused his energies on destroying Mitchell and framing himself as the defender of public interest, his once impervious restraining power over the dispatch of troops began to erode due to several developments. Although public opinion appears to have initially remained in Pitt's camp, powerful opponents of non-intervention emerged from Britain's military establishment. Many became concerned about broader implications of Britain's military remaining relatively inactive. ${ }^{128}$ According to Joseph Yorke, many of “our officers \& Men ... certainly don't want to learn less than their Neighbours, $\&$... see themselves outstripp'd by their contemporaries in other countries, in every Branch of the military Profession." ${ }^{129}$ In support of Yorke's claims, at least three generals wrote directly to Newcastle expressing their preference for service in Germany over that in America or with the fleet along the French coast. George II's preference for activity in Germany further tipped the scales in Newcastle's favor. Late in 1757, the monarch delivered a speech clearly expressing his desire to see British involvement on the Continent. Because nothing resulted from his public appeal, the King offered in the spring of 1758 to personally finance six thousand men (which amounted to roughly fifty percent of the troops ultimately sent) for service in Germany. George II's generous 'gift' to his nation effectively undercut Pitt's financial objections. Finally, opposition to direct British involvement in Germany began to wane as Ferdinand of Brunswick, against many observers' expectations, roused his Hanoverian forces to activity and, at least temporarily, fared well against his numerically superior French foes. Ferdinand's successes in the summer of 1758 , combined with reports that the French planned on significantly augmenting their forces arrayed against the prince, finally convinced Newcastle's opponents to concede to his long-standing demands for a direct commitment to the Continent. ${ }^{130}$ "[F]or the moment," an informant concluded to Newcastle regarding Ferdinand's initial successes, "the public seems to think it

${ }^{128}$ Yorke to Newcastle, January 10, 1758 in NP, BL, 32877.

${ }^{129}$ Yorke to Newcastle, November 27, 1757 in NP, BL, 32876.

${ }^{130}$ Yorke to Newcastle, December 13, 1757; Intelligence, December 24, 1757 in NP, BL, 32876; Newcastle to Hardwicke, March 24, 1758 in NP, BL, 32878; Drat. Of Declaration, April, 1758 in NP, BL, 32879; Rockingham to Newcastle, July 3, 1758, Newcastle to Legge, July 6, 1758, Major General Mostyn to Newcastle, July 10, 1758; Newcastle to Campion, July 15, 1758 in NP, BL, 32881. 
[troops going to Germany] better than spending money to brake a few windows in France," referring to Pitt's preferred policy of raiding the French coastline. ${ }^{131}$

Ever the opportunist, Pitt recognized the shifting situation and finally conceded to Newcastle's push for English troops on the Continent. The ministers initially agreed to dispatch six thousand troops, but Newcastle and his allies continuously called for augmentations of the original commitment. These efforts resulted in the ultimate investment of twelve thousand men by the end of the summer of 1758, when Pitt finally dug his heels in and insisted that no more resources be sent. Throughout this alteration of British policy, the Secretary insisted that he not be publicly connected to the Ministry's actions, and Newcastle possessed no recourse but to reluctantly concede. ${ }^{132}$ Beyond this, Newcastle operated under the continued reality that if Pitt changed his mind, or the situation that had resulted in his change of heart reversed itself, "[t]he English Troops possibly may be recalled, \& we shall have all the disagreable Altercations about Hanover Armies, \& Hanover Measures, that we have formerly seen." ${ }^{133}$ Despite these limitations, the Duke had finally achieved his primary aim of directly pursuing combat on the Continent and by doing so, Britain would "shew our Friends, that we mean to do something in this War."134 To accomplish his goal, however, Newcastle had expended significant political capital with both the British public and his principal rival. Such an expenditure likely made it impossible for him to act on behalf of his ideological allies in Pennsylvania's proprietary faction because it risked further harming his position with Pitt and a British public that remained cautious about any action that indicated a curtailment of liberties.

While Newcastle's Whigs appeared ideologically aligned with Pennsylvania's proprietary faction, Pitt's opposition Whig stance likewise suggested a compatibility with the province's popular faction.

${ }^{131}$ Gordon to Newcastle, July 19, 1758 in NP, BL, 32881.

${ }^{132}$ Cleveland to Newcastle, March 25, 1758 in NP, BL, 32878; Newcastle to Rockingham, Jun 24, 1758, Newcastle to Yorke, June 30, 1758; Newcastle to Yorke, July 7, 1758 in NP, BL, 32881; Newcastle to Holdernesse, July 22, 1758, Holdernesse to Newcastle, July 25, 1758; Mansfield to Newcastle, July 17, 1758 in NP, BL, 32882.

${ }^{133}$ Newcastle to Hardwicke, July 23, 1758 in NP, BL, 32882.

${ }^{134}$ Newcastle to Yorke, June 30, 1758 in NP, BL, 32881. 
Reforming Britain's Habeas Corpus legislation, the "happiest and best work of my publick Life," proved the core of Pitt's political agenda. ${ }^{135}$ Britain had possessed such legislation since the Glorious Revolution, but oppositional Whig sentiment condemned it as inadequate because judicial power remained too strong and judges proved dependent on the Crown. For Pitt and his allies, the situation threatened the very liberties of the British people. ${ }^{136}$ "He would battle any living authorities," an advisor warned Newcastle, because even the most talented and honest judges "were dangerous when employed in [giving] away the great principles of Liberty." ${ }^{137}$ Time after time in dealing with his Whig opponents, the Secretary cited English liberties and accused anybody who opposed reform of being an "enemy of liberty." ${ }^{138}$ As he had on so many other issues, Pitt believed that Newcastle and his allies defended the prerogatives of the Crown at the expense of the people. As the Secretary threatened violence if his demands went unmet, some of these allies ignored his claims, choosing to believe that the opposition fomented intrigue and created issues that did not resonate with the people. Newcastle knew better. ${ }^{139}$ "If this method of proceeding is not stopt," he informed Hardwicke, "we shall have the Mob at the Door of the House of Lords, Demanding justice, if they presume to differ from the House of Commons." ${ }^{140}$ To combat this populist unrest, the Duke pursued a policy he would use again to great effect-embrace the legislation while ensuring that Whig sentiments tempered the more democratic elements. In this case, he directed the reforms towards the judges themselves, arguing that they would

${ }^{135}$ Pitt to Newcastle, May 22, 1758 in NP, BL, 32880.

${ }^{136}$ Hardwicke to Newcastle, May 2, 1758 in NP, BL, 32879; West to Newcastle, June 16, 1758 in NP, BL, 32880 .

${ }^{137}$ West to Newcastle, April 24, 1758 in NP, BL, 32879.

${ }^{138}$ Newcastle to Hardwicke, April 14, 1758 in ibid.

${ }^{139}$ Newcastle to Hardwicke, April 14, 1758; Devonshire to Newcastle, April 29, 1758 in ibid; Pitt to Holderness, May 11, 1758, Newcastle to Hardwicke, May 16, 1758; Hardwicke to Newcastle, May 22, 1758 in NP, BL, 32880 .

${ }^{140}$ Newcastle to Hardwicke, March 27, 1758 in NP, BL, 32878. 
be the most knowledgeable at suggesting proper alterations. His outwardly reasonable proposal resulted in the dissipation of much of the public furor over the issue. ${ }^{141}$

Pitt also embraced a militia movement reminiscent of that attempted by the popular faction in Pennsylvania. In November 1757, riots erupted in parts of England. Newcastle's informants indicated that they resulted from many citizens' objections to the practice of quartering troops in private homes. The practice had been instituted as home defense forces swelled and barrack construction lagged due to associated costs. Rather than support increased construction of barracks at the taxpayers' expense, opponents suggested a reduction in forces and a dependence on a better organized militia of citizen soldiers who would solve the problem by residing in their own homes. ${ }^{142}$ "[T] hey expect to have the militia made the basis of theire more desired events," Gordon reported to Newcastle, "especaly that of having the army reduced."143

The Duke and his allies opposed the extension of a militia as dangerously populist and damaging to the strength of the monarchy. The new militia bill promoted by Pitt attempted to alter the provisions of the old method of appointing officers. Under that system, royally authorized Lords Lieutenants, generally comprised of elite residents of the different regions of the nation, selected individuals to command local militias. Whig politicians could tolerate such a situation because a clear line of patronage ensured that officers would be loyal to the monarchy. ${ }^{144}$ The new proposals, however, required the Lords Lieutenants to confer office to those elected by the militiamen themselves, leading Newcastle to fear the rise in power of “[l]ow, or Improper People." ${ }^{145}$ The Whigs deeply suspected that those elected to office, if allowed under a new bill, might be enemies to the government. In the worst

${ }^{141}$ Hardwicke to Newcastle, May 17, 1758; Devonshire to Newcastle, May 29, 1758 in NP, BL, 32880.

${ }^{142}$ Newcastle to Osbaldeston, November 5, 1757 in NP, BL, 32875; Gordon to Newcastle, February 13, 1758 in NP, BL, 32877.

${ }^{143}$ Gordon to Newcastle, January 15, 1758 in NP, BL, 32877.

${ }^{144}$ Lord Shaflesburgh to Newcastle, April 27, 1758 in NP, BL, 32879.

${ }^{145}$ Newcastle to Hardwicke, June 3, 1758 in NP, BL, 32880. 
case scenario, some feared that a populist militia could eventually be turned against the Crown. ${ }^{146}$ When the Whigs attempted to diminish the call for a popular militia by increasing funds for barrack construction and thus eliminate one source of unrest, they believed the true intentions of their political opponents became clear. "[S]triping the crown of its military power;" Gordon suggested to Newcastle, "[is] preferable to that of Barracks for them." ${ }^{147}$ Finally, opponents to a reformed militia attempted to raise apolitical objections. "[T]hey [France] would be rather animated to invade us then daunted of by the best regulated malitia," Gordon theorized, "without a powerfull army commanded by experienced officers depending on the crown." 148

Despite the Whigs' fervent opposition to a new militia bill, Newcastle came to recognize the dangers of continuing to block it as Pitt encouraged popular support to pressure the House of Commons to support his scheme. ${ }^{149}$ The tide turning against him as the Commons passed legislation, Newcastle conceded, noting "I care no more for the militia than you do, but I do care for an act of Parliament." 150 In control of the House of Lords, however, the Whigs refused to entirely surrender their views without placing their own restrictions on the new elections. In An Act for the better ordering the Militia Forces in the several Counties of that Part of Great Britain, called England, passed in June by a two to one vote in the House of Commons, the Whigs had managed to preserve a sort of 'right of refusal'. While militias now elected their own officers, the Lords Lieutenants possessed the power to refuse commissioning anybody deemed unfit for service. This left them wide latitude, and Newcastle's actions as the Lord Lieutenant of Middlesex County clearly demonstrate the effectiveness of this democratic restraint. As the militias organized elections in July 1758 , the Duke commissioned agents to gather the names of those planning to run. After identifying individuals he hoped to block, he again dispatched 'friends' to

\footnotetext{
${ }^{146}$ Gordon to Newcastle, November 5, 1757 in NP, BL, 32875; Gordon to Newcastle, July 7, 1758; Anonymous to Newcastle, July 18, 1758 in NP, BL, 32881.

${ }^{147}$ Gordon to Newcastle, June 22, 1758 in NP, BL, 32881.

${ }^{148}$ Gordon to Newcastle, Jun 9, 1758 in NP, BL, 32880.

${ }^{149}$ Newcastle to Devonshire, April 29, 1758 in NP, BL, 32879.

${ }^{150}$ Newcastle to White, August 11, 1758 in NP, BL, 32882.
} 
campaign against those individuals. ${ }^{151}$ Ultimately, although Newcastle had successfully removed the most populist of the provisions of the new militia bill, Pitt's fervent support of it suggests an ideological connection to those in Pennsylvania who had pursued a similar object in the colony.

Beyond Pitt's domestic politics, his commitment to Britain's maritime interests suggested an intervention in the Pennsylvanian debate. Opposition Whigs and their Tory allies favored what came to be called 'blue water strategy'. The concept emphasized a reliance on small mobile military forces that could be speedily moved from place to place by a navy superior to any possessed by Britain's enemies. The strategy opposed large-scale military commitments necessary to fight a Continental conflict and thus became the favorite of those hoping to minimize costs while still possessing a military capable of defending and advancing Britain's global commercial interests. ${ }^{152}$ Those, such as Pitt, who ascribed to blue water strategy thus tended to view conflicts in more global perspectives and proved more likely to be attentive to the concerns of Britain's colonies.

As a consequence of such viewpoints, many Britons believed fervently that the war would be won or lost outside of Europe. ${ }^{153}$ Pitt expressed his belief clearly, lecturing Newcastle that "so important ... a scene as the campaigns in America, where England and Europe are to be fought for." ${ }^{154}$ James Abercromby, Commander in Chief of British forces in North America in 1758, maintained the same reasoning, suggesting to the governor of Virginia that "[p]eace must come from the American Continent, come what will of Other Continents."155 Such a belief-that of the preeminence of American campaigns over those in Europe to the successful conclusion of the conflict-appeared confirmed by intelligence

${ }^{151}$ Newcastle to Devonshire, June 9, 1758 in NP, BL, 32880; Newcastle to Roberton Sutton, John Hewitt, John White, Job Staunton Charlton, Ralph Knight, William Molineux, July 11, 1758, Newcastle to Abergarenny, July 15, 1758; Newcastle to John Hewett, July 15, 1758 in NP, BL, 32881; John Higgs to Newcastle, August 8, 1758; Hardwicke to Newcastle, August 16, 1758 in NP, BL, 32882.

${ }^{152}$ Louis M. Waddell, "Defending the Long Perimeter: forts on the Pennsylvania, Maryland, and Virginia Frontier: 1758-1765." Pennsylvania History. Vol. 65, No. 2 (Spring, 1995): 171-172.

${ }^{153}$ Philip Stanhope to Newcastle, March 3, 1758 in NP, BL, 32878; Chesterfield to Newcastle, June 10, 1758 in NP, BL, 32880 .

${ }^{154}$ Pitt to Newcastle, December 27, 1757 in NP, BL, 32876.

${ }^{155}$ James Abercromby to Fauquir, November 17, 1758 in OPFF, 1:106. 
from France. ${ }^{156}$ According to Newcastle's French informant, "if your court can distress us in america . . .you may justly hope to see us very sick of the War." ${ }^{157}$ Indeed, Joseph Yorke in Holland suggested that all of Europe awaited events transpiring overseas, noting that "at present there seems to be a suspension of interior Events, as all Eyes are fix'd upon what is doing abroad."158

While many believed that victory overseas, and particularly in North America, represented the clearest path to a successful conclusion to the conflict, Newcastle and his allies disagreed. "Mr. Pitt looks too much to one part of the World only;" Newcastle lamented to a colleague. "That is, \& ought to be, a great object, but not the only one, even for the sake of that object itself," he continued, "[m]inisters in this Country, where Every part of the world affects us, some way or other, should consider The whole Globe." ${ }^{159}$ Newcastle's previous actions, of course, clearly demonstrated that to him, the 'whole globe' equated to Europe alone. The King as well made his feelings known in the matter. "He said We wished Him to spend all His money; To ruin Himself, and To do nothing then for

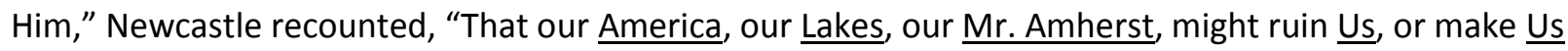
Rich, but, in all Events, He should be undone." ${ }^{160}$ Yet despite this powerful opposition, the arguments made by blue water proponents proved too numerous, too sound, and too validated to be ignored.

According to those wishing to see a global and maritime war effort preempt Continental commitments, numerous advantages appeared paramount to such an approach. Proponents of a global military focus pointed to the economic benefits as justification of their views. ${ }^{161}$ "Ignorant People say what is the Ohio to us," one observer noted, "what expense is there like to be about it, shall we bring on a war for the sake of a River, the name indeed is nothing, but the consequence of that River is of the utmost Importance to Great Britain, as it opens a free communication for our Enemies to distress \&

${ }^{156}$ Intelligence, January 24, 1758 in NP, BL, 32877.

${ }^{157}$ Intelligence, February 4, 1758 in ibid.

${ }^{158}$ Yorke to Newcastle, August 1, 1758 in NP, BL, 32882.

${ }^{159}$ Newcastle to Holdernesse, July 25, 1758 in ibid.

${ }^{160}$ Newcastle to Hardwicke, January 3, 1758 in NP, BL, 32877.

${ }^{161}$ Reflections on the Present State of America, 1756 in PRNA, BL, 33029. 
subdue Us on every side, for it is generally agreed, that those that remain Masters of the Ohio Country, will be undoubtedly masters of all the Colonies." ${ }^{162}$ Thomas Robinson, while serving as a Secretary of State prior to Pitt's ascension, concurred when he argued "it is from them [colonies] great part of the wealth we see, that credit which circulates, and those payments that are made at the Bank, \& the Bankers, in London, results; and They are so linked in with and dependent upon the American Revenues \& Remittances, that if They are ruined \& stopt, the whole system of public credit in this country will receive a fatal shock." ${ }^{163}$ Thus, according to Robinson, the very ability of the nation to conduct war relied entirely on the continued flow of trade with the North American colonies. Any increase resulting from the addition of new colonies would serve to augment the funds available to the government. William Shirley, governor of Massachusetts and temporary Commander in Chief of British forces in North America, suggested one final economic motive for heavy British involvement in the colonies. In a letter to the Ministry, the governor-general:

"enters into long Reasonings on the many advantages of taking Canada, \& driving the French entirely out of No. America, $\&$ as to the Expence of maintaining such a large acquisition, He thinks a less Force will be sufficient, than what is now necessary to defend the Frontiers against the encroachments of the French, \& the Depredations of their Indians; \& Mr. Shirley imagines that a Body of 3000 men, including the 4 Companies at New York, \& that at So. Carolina will be sufficient; and the increase of the Fur Trade, \& the Provinces being eased from any apprehensions on their Frontiers, will enable them to contribute largely to the Expence of these Troops." 164

Shirley's suggestions added powerful motivation to those of Robinson. By making a strong initial commitment to North America, Britain might significantly augment its trade revenue while

\footnotetext{
${ }^{162}$ Some Thoughts on the French Scheme and the Ohio Country by P. Collison, ND, PRNA, BL, 33029.

163 Thomas Robinson, August 29, 1755 in HP, BL, E6.

${ }^{164}$ Plan for the Reduction of Canada, Mr. Shirley, August 15, 1755 in PRNA, BL, 33029.
} 
simultaneously decreasing its long-term costs by reducing the need to maintain North American defense if it expelled France from the Continent.

Beyond the Americas, Pitt and his allies pursued aggressive operations elsewhere. While the Secretary counted pennies in the funding measures to Britain's German allies, he sent a foreign agent based in Constantinople to Newcastle with a request for fifteen thousand pounds for operations, most likely relating to intrigue, in that court. The minister likewise encouraged the House of Commons to provide twenty thousand pounds for the support of the East India Company's actions in India. Perhaps most surprisingly, a colonial merchant named Thomas Cumming convinced Pitt of the lucrative advantages a campaign in West Africa might provide. Towards that end, the Secretary dispatched troops and a naval squadron that might have been used in the more strategically important American or European theaters to make a strike at French holdings along the Senegal River. Seven hundred marines led by Major Mason and six naval vessels commanded by Captain Marsh compelled the capitulation of 232 French soldiers with ninety-two artillery pieces. The capitulation gave the British control of the strategic island of Gorcé, Fort Lewis situated twelve miles up the Senegal River, and all the commercial resources of the French colony. The haul included fifty thousand dollars, five hundred slaves, quantities of gold and gold dust, four hundred guns and the ninety-two cannons, quantities of various trade goods, provisions and stores, and a secure source of gum for British merchants. ${ }^{165}$ The incredible success in West Africa prompted Lord Cleveland, head of the Admiralty, to declare to Newcastle that the enterprise was "much more beneficial to this country than many other conquests, for besides the beneficial trade now opened to the English what is taken in Fort Lewis amounts to a great sum."166 The head of the Royal Navy, Lord Anson, further questioned Newcastle's commitment to Continental

${ }^{165}$ Holdernesse to Fox, March 31, 1755 in HP, BL, E6; Marsh to Cleveland, May 28, 1758, West to Newcastle, May 31, 1758, West to Newcastle, June 1, 1758, Porter to Newcastle, June 9, 1758, Stanley to Admirality, June 10, 1758; Extract of Acct. received from the Coast of Africa, June 10, 1758 in NP, BL, 32880.

${ }^{166}$ Cleveland to Newcastle, June 10, 1758 in NP, BL, 32880. 
measures in light of the profitable endeavor, asking the Duke if he had changed "your old fashioned way of thinking about continent measures?"167 Newcastle, or at least some of his supporters, had not. In private correspondence, one advisor complained to the Duke that the House of Commons dispensed funds for overseas measures without a pause, while Whig supporters of a Continental focus fought for German support every step of the way. ${ }^{168}$

A strong offensive abroad would also, supporters argued, cripple French commerce and reduce its ability to continue the conflict. By 1758, reports of the Royal Navy's successes against its French counterpart began pouring into the Cabinet. The damage done to Louis XV's shipping weakened both his ability to fund the war and provide concrete support to his colonies. ${ }^{169}$ From Holland, Joseph Yorke reported that "[t]he French continue very uneasy about their colonies, and their best officers fear for North America . . as well as for the want of seamen at Brest to man the Fleet."170 The diplomat and his counterpart in Prussia suggested additional advantages to this destruction of French commerce. By stepping in to fill the void left by the absence of French products, Britain might bind European nations starving for global products more closely to its interests. Specifically, the two ambassadors believed that Holland and Russia might be won over by their increased dependence on trade with Great Britain. In addition to these advantages, supporters claimed that if France attempted to seriously challenge these strong efforts in the colonies, it would divert significant resources away from Germany and thus effectively diminish the need for British troops to be engaged in that theater. ${ }^{171}$

${ }^{167}$ Anson to Newcastle, June 29, 1758 in NP, BL, 32881.

${ }^{168}$ West to Newcastle, May 31, 1758 in NP, BL, 32880.

${ }^{169}$ Intelligence, November 22, 1757 in NP, BL, 32876; John Gordon to Newcastle, January 6, 1758; Potts to Newcastle, January 10, 1758 in NP, BL, 32877; Extract of a Letter from Dunkirk, March 17, 1758, Holdernesse to Newcastle, March 25, 1758; Duke of Devonshire to Newcastle, March 25, 1758 in NP, BL, 32878; A Plan for Taking the Island of Belle Isle, ND; Cleveland to Newcastle, May 11, 1758 in NP, BL, 32880; Cleveland to Newcastle, July 4, 1758 in NP, BL, 32881; Cleveland to Newcastle, July 21, 1758 in NP, BL, 32882.

${ }^{170}$ Yorke to Newcastle, February 3, 1758 in NP, BL, 32877.

${ }^{171}$ Mitchell to Holdernesse, October 30, 1757 in NP, BL, 32875; Yorke to Newcastle, ND in NP, BL, 32877; Holdernesse to Mitchell, ND in NP, BL, 32878; Intelligence, April 25, 1758 in NP, BL, 32879. 
To conform to his commitment to blue water strategy, Pitt adjusted Britain's military strategy in late 1757. Instead of supporting direct involvement in the Continental war, the Secretary proposed instead to develop a small expeditionary force that could be transported by the navy to conduct pinprick raids on the French Atlantic coast. To accomplish his goals, the minister ordered the seizure and occupation of various channel islands, ultimately establishing the Isle of Wight as the military's principle base of operations. By the spring of 1758, Britain prepared to launch multiple raids into French territory. In March, the British landed troops to occupy the city of Emden in Hanover to support Ferdinand's army. Landing forces destroyed more than one hundred ships, at an estimated value of five million livres, while losing only one man at St. Maloes in June. The French reported a raid on Cape Breton in July, and British troops damaged the port facilities in Cherbourg in August. A large raiding force also attempted to strike the town of Rocheport. ${ }^{172}$

Supporters of Pitt's program enthusiastically lauded the significance of these actions. On an economic level, supporters claimed that raids, such as the one at St. Maloes, which had destroyed so many ships, seriously harmed French commerce. Reports from Newcastle's French informant, although not public knowledge, confirmed the disastrous state of France's mercantile capability by the summer of 1758. In addition, many argued that France would need to divert troops from the battlefields of Germany back to its coasts to defend against the unpredictable raids. ${ }^{173}$ According to Newcastle's spy, "the arrival of your Fleet on our Coasts, has increased the perplexity of this court, \& made them very

${ }^{172}$ Substance of what passed between Mr. Secry Pitt; My Lord Holdernesse, March 27, 1758; West to Newcastle, ND, West to Newcastle, January 28, 1758; West to Newcastle, January 31, 1758 in NP, BL, 32877; Newcastle to Legge, March 30, 1758 in NP, BL, 32878; Pitt to Newcastle, May 11, 1758, Marlborough to Pitt, June 6, 1758, Note from Mr. Pitt, June 16, 1758, Newcastle to Holderness, June 16, 1758, Newcastle to Hardwicke, June 16, 1758; Hardwicke to Newcastle, June 17, 1758 in NP, BL, 32880; Pitt to Newcastle, June 23, 1758, Mr. Reiche, June 25, 1758, Holdernesse to Newcastle, June 25, 1758, Holdernesse to Lords Commissioners of the Admirality, July 13, 1758; Hardwicke to Newcastle, July 20, 1758 in NP, BL, 32881; Hugh Valence Jones to Newcastle, August 11,1758 in NP, BL, 32882..

${ }^{173}$ Commander Holmes to Cleveland, March 21, 1758 in NP, BL, 32878; Intelligence, May 17, 1758, Intelligence, May 31, 1758; Intelligence, June 4, 1758 in NP, BL, 32880; Intelligence, June 21, 1758, Gordon to Newcastle, July 3, 1758; Intelligence, July 20, 1758 in NP, BL, 32881; Newcastle to Robinson, August 12, 1758 in NP, BL, 32882. 
apprehensive of the great Progress your arms may make."174 The same source suggested as well that the French withdrawal from Germany strained the relationship between France and Austria. The raids possessed further diplomatic advantages. ${ }^{175}$

According to Holdernesse, "Mr. Pitt was strongly of opinion, That nothing could be more satisfactory to The King of Prussia, in the present Moment, than an Assurance, That the Forces of England should be put in such a state, as to give an immediate Alarm to France, \& to be actually in Readiness to act offensively, if any proper Moment should happen to strike a stroke upon the Coasts of France." ${ }^{176}$ Pitt's suggestion pertaining to Frederick proved correct, as both of Britain's principle diplomats on the Continent, Yorke and Mitchell, independently confirmed that the raids satisfied the King's demands. Frederick even toyed with a plan to have Prussian forces landed by the Royal Navy. Correspondence between Newcastle and the Dutch royal family further indicated that the raids had a positive effect on the population of that nation as well. As a consequence, supporters of Pitt's plans could rightfully claim that the raids had a salutary effect on the nation's diplomacy with its current and desired allies. $^{177}$

The Secretary's plans to commit most of Britain's resources to raiding the French shoreline provided one additional benefit-home defense. According to Lord Ligonier, Commander-in-Chief of the army, "if the Enemy should make an attempt here, you have not 1000 men to march against them." ${ }^{178}$ Thus, according to Pitt, keeping most of British forces out of Germany and quartered off the coasts of France would ensure they "would always be at Hand, for Home Defence." ${ }^{179}$ Although an

\footnotetext{
${ }^{174}$ Intelligence, March 28, 1758 in NP, BL, 32878.

${ }^{175}$ Intelligence, June 30, 1758 in NP, BL, 32881. BL, 32878.

${ }^{176}$ Substance of what passed between Mr. Secretary Pitt, \& My Lord Holdernesse, March 27, 1758 in NP,

${ }^{177}$ Mitchell to Holdernesse, ND in NP, BL, 32877; Newcastle to Hardwicke, February 26, 1758 in NP, BL, 32878; Newcastle to Her Royal Highness the Princess Royal, April 4, 1758 in NP, BL, 32879; Yorke to Newcastle, June 14, 1758 in NP, BL, 32880.

${ }^{178}$ Hardwicke to Newcastle, July 24, 1758 in NP, BL, 32882.

${ }^{179}$ Newcastle to Hardwicke, August 14, 1758 in ibid.
} 
invasion of the British Isles appears farfetched in retrospect, the fear certainly existed among the nation's populace and Newcastle's source of intelligence in France indicated that France had considered the possibility. ${ }^{180}$

To support his plans, Pitt worked hard to foster public support for his expeditions and counter the claims made by his Whig opponents that the raids proved expensive and inconclusive. He began by targeting the army officers entrusted with executing the strategy. In September of 1757, Sir John Mordaunt failed to land any troops in an abortive raid on the town of Rochefort. Sensing a popular backlash against the Secretary, the Whigs reveled in this failure. ${ }^{181}$ "Mr. Pitt is apprehensive, That these Disappointments ... will make all other Expensive operations, go heavier, or not at all," Newcastle reported to Hardwicke, "[b]ut perhaps, The more True Reason may be . . that it may shew, How Idle, \& Improper It was, To depend singly upon such a kind of war." ${ }^{182}$ Hardwicke concurred, replying that "[h]e [Pitt] is certainly at present greatly affected by the failure of his own ... great Projects, \& by a sensibility that He shall be forced to defend himself by the like kind of Arguments, which He has exploded \& run down in the case of Those, who have gone before Him.." ${ }^{183}$ Hardwicke here referred to the tactics that Pitt had used to elevate himself to power, which had included publicly attacking the Ministry for embarrassing defeats that had typified Britain's early war effort. In particular, the Secretary had publicly condemned his opponents for losing Minorca in 1756. The resultant public furor had led to the execution of Admiral Byng for dereliction of duty off the shores of that strategic island in the Mediterranean. To defend his policies, Pitt deflected blame to the officers, going so far as to publish pamphlets to support this conclusion. ${ }^{184}$ To further buttress his point, the Secretary resolved to make an example of Mordaunt as had been done to Byng a year earlier. "Mr. Pitt is very violent, upon the

${ }^{180}$ Intelligence, November 21, 1757 in NP, BL, 32875; Intelligence, December 7, 1758 in NP, BL, 32876

${ }^{181}$ Gordon to Newcastle, July 21, 1758 in NP, BL, 32882.

${ }^{182}$ Newcastle to Hardwicke, October 15, 1757 in NP, BL, 32875.

${ }^{183}$ Hardwicke to Newcastle, October 24, 1757 in ibid.

${ }^{184}$ Newcastle to Hardwicke, October 15, 1758 in ibid; Newcastle to Hardwicke, June 18, 1758 in NP, BL, 32880. 
Behaviour of The Land officers, which He attributes to a formed Design in great Part of the Army against

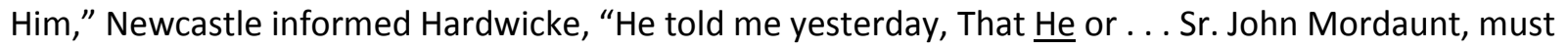
be tried ... Thinking, (and He thought right) That The Measure would greatly increase His popularity, when it should appear, That it failed purely from the Behaviour of the Land officers." 185 Under pressure from Pitt, royal authorities arrested and tried the general for disobedience in December. ${ }^{186}$

Although the military tribunal ultimately acquitted the embattled commander, Pitt's actions had two ramifications. On the one hand, it further poisoned the Whigs and high-ranking military officers against the raids. ${ }^{187}$ The Whigs abhorred the persecution of Mordaunt, and feared that future failures might result in a string of like actions against men "of quality, rank, \& distinction." ${ }^{188}$ As a consequence, Newcastle claimed that "[a]ll the Officers \& Generals are so fond of going to Germany, That it is very difficult to find a general to command our Expedition. ${ }^{\prime 189}$ On the other hand, the Secretary's populist appeals appear to have succeeded, leading to wide popular acclaim and support for the expeditions. ${ }^{190}$ Pitt's policies thus revolved around acquiring and maintaining popular support with the British public. Support for the popular faction of Pennsylvania, which mirrored public concerns about threats to liberty and was currently engaged in waging a public relations battle in Britain with the proprietary faction, should have appeared to Pitt as a clear avenue for solidifying his position as the nation's defender of liberties. Consequently, the Secretary's inattentiveness to the popular faction's appeals proves as surprising as Newcastle's failure to act on behalf of the proprietary faction.

\footnotetext{
${ }^{185}$ Newcastle to Hardwicke, October 15, 1757 in NP, BL, 32875.

${ }^{186}$ Holdernesse to Barrington, December 3, 1757 in HP, BL, E6; Message on S.J. Mordaunt, December 6, 1757 in NP, BL, 32876.

${ }^{187}$ Holdernesse to Newcastle, July 3, 1758, Newcastle to Mostyn, July 14, 1758; Newcastle to Legge, July 15,1758 in NP, BL, 32881.

${ }^{188}$ Hardwicke to Newcastle, October 16, 1757 in NP, BL, 32875.

${ }^{189}$ Newcastle to Col. Townsend, July 15, 1758 in NP, BL, 32881.

${ }^{190}$ Helen Anderson to John Forbes, July 25, 1758 in Forbes Papers (hereafter FP), Scottish National Archives (hereafter SNA), GD 45/2/97, Edinburgh; Watkins to Newcastle, June 19, 1758 in NP, BL, 32880; Robert Keith to Newcastle, July 10, 1758 in NP, BL, 32882.
} 
Pitt's inaction might best be explained by the avenue he took to acquire his lofty position and the resultant steps he believed he needed to take to maintain his office. When he accepted the position of Secretary of State for the Southern Department in 1757, Pitt assumed responsibility for North American affairs. By this point, North America had been subdivided into Northern and Southern Districts to assist in managing military affairs. The Southern District, which would ultimately be commanded by General John Forbes in 1758, consisted of Pennsylvania, Delaware, Maryland, Virginia, North and South Carolina, and Georgia. Pitt found the District to be in a woeful situation. In the South, reports filtered in about "the Designs of the French to make some attempt on South Carolina."191 Although the colony boasted a militia of 8,400 men, much of it remained committed to controlling the slave population and thus proved insufficient to quiet the colony's fears. Georgia remained even worse off, possessing a militia of only eight hundred men, leading its governor to lament about "our weak and exposed condition." ${ }^{192}$ British authorities moved quickly to strengthen their position. In April, Governor Dobbs of North Carolina committed to "defend South Carolina in Conjunction with the other Provinces." ${ }^{193}$ Virginian Governor Dinwiddie sent two hundred men to South Carolina's assistance in May. Even Lord Loudon, then the Commander-in-Chief of North America, detached badly needed troops for his Louisburg Campaign to South Carolina. Not to be outdone, Pitt himself ordered Colonel Archibald Montgomery's newly raised highland battalion to South Carolina directly from Britain with the admonition to "assist [South Carolina] and cooperate with Governor Lyttelton."194

To the north, the situation appeared even more troublesome. With Fort Duquesne serving as a base, French and allied Indians actively raided the frontiers of Pennsylvania, Maryland, and Virginia. In Pennsylvania and Virginia alone, reports counted 261 colonial deaths and 205 colonists captured by the

${ }^{191}$ Pitt to Lyttleton, March 31, 1757, Kimball, Correspondence of Pitt, 1:28-29.

192 The militia numbers are listed in Gipson, Great War, 7:27-28. Governor Ellis's lament is contained in Ellis to Pitt, May 25 1757, Kimball, Correspondence of Pitt, 1:68.

${ }^{193}$ Dobbs to Pitt, April 16, 1757 in Kimball, Correspondence of Pitt, 1:34.

${ }^{194}$ Dinwiddie to Pitt, May 14, 1557, Ibid, 1:65; Loudon to Pitt, April 25, 1757, Ibid, 1:49; and Pitt to Montgomery, March 31, 1757, Ibid, 1:27. 
French and their native allies. Although reports varied about the garrison's strength, Governor

Dinwiddie "supposed fort Du Quesne has been reinforced with a great No. of forces from the

Mississippi." ${ }^{195}$ Despite such terrifying losses, the disputes between the Pennsylvania Assembly and the colony's governor over funding for provincial troops resulted in deadlock. Loudon, busy preparing for the campaign to Louisburg and unwilling to part with troops, consented to subsidies for Pennsylvania's soldiers or, as he put it, "their troops would have disbanded immediately, and that Province laid open to be a Prey to the Enemy." ${ }^{196}$

Despite the best efforts of colonial governors, Loudon, and Pitt himself, the situation of the Southern District in 1757 inspired little confidence. Dinwiddie, while trying to remain optimistic, noted that the state of the southern colonies "bears a gloomy Aspect." ${ }^{197}$ Part of the blame can justifiably be attributed to Pitt. Nowhere in his orders did the Secretary propose offensive operations in the south. Instead, he remained content to stay on the defensive while pinning all his hopes on a successful conclusion to Loudon's Louisburg campaign. Pitt had clearly yet to realize the importance of military victories to his political career, a surprising revelation considering his rise to power rested on his opposition to Newcastle's previous ministry's mishandling of the defense of Minorca in 1756. That spring, however, Pitt must have been riding high on his recent ascent to power as the dominant player in the short-lived Pitt-Devonshire ministry. It would take that ministry's failure, and the reconstitution of his power in the Pitt-Newcastle ministry, to make Pitt fully aware of the particular importance of victories to his popularly-based political position.

${ }^{195}$ For reports of Duquesne's strength, see Dinwiddie to Pitt, June 20, 1757 in Ibid, 1: 83 and Sharpe to Pitt, October 22, 1757, Ibid, 1:123. Sharpe also discusses Indian raids. Green discusses the use of Duquesne as a base for raiding at some length in Green, William Pitt, 133. The killed and captured figures come from Ward, La Guerre Sauvage, 440-452.

${ }^{196}$ Loudon to Pitt, April 25, 1757, Kimball, Correspondence of Pitt, 1:41.

${ }^{197}$ Dinwiddie to Pitt, June 20, 1757, Ibid, 1:84. 
Pitt also needed to learn about America, and his management of colonial affairs in the spring of 1757 led him to question defensive measures in the southern colonies. ${ }^{198}$ In a letter dated June 17, Loudon reported to Pitt that "Lieutenant Colonel Bouquet has Orders, to give them [Georgians] all the Support in their Power, but they are too far from him, for him to be able to do anything material for them."199 In other words, defensive measures would not win the war, and pursuing such policies additionally dispersed Britain's limited resources to no positive purpose. Britain's North American colonies comprised a large area, and as Loudoun indicated in 1757, British forces proved too dispersed to assist all the colonies in their defense. Instead, Pitt's insistent orders for 1758 to conduct offensive operations must be seen as an attempt to consolidate provincial and royal forces to strike at the centers of French power in the New World. His plans for 1758 thus proved entirely different from 1757, with defensive measures taking a backseat to offensive ones. ${ }^{200}$

Additionally, Pitt left Loudon tremendous independence to shape North American affairs in 1757. Although he remained convinced that control of Quebec and Louisbourg would prove decisive, he left local decisions to Loudoun, stating "as ... enterprises may depend on circumstances, not to be known here, His Majesty is pleased to leave some latitude to your Lordship's discretion and judgement.." ${ }^{201}$ Commanders sent from Britain with additional troops received similar orders-they were to defer to Loudoun on all counts. The general, meanwhile, met with colonial governors from the Southern District in Philadelphia in March, hoping to organize their collective efforts. Offense did not factor into his plans. "A plan has been proposed to me," he notified Pitt, "for an Attack from that [the

${ }^{198}$ Pitt details such a policy while writing to Governor Denny of Pennsylvania. His plans are related in William Pitt to Governor Denny, February 4, 1757, William Pitt Family Papers, 1757-1804, DAR.1925.08, Darlington Collection, Special Collections Department, University of Pittsburgh: Pittsburgh.

${ }^{199}$ Loudon to Pitt, June 17, 1757, Ibid, 1:79.

${ }^{200}$ Middleton discusses Pitt's process of gathering information in Middleton, Bells of Victory, 50-51. W. Kent Hackmann illuminates Pitt's need to carefully use his limited resources in W. Kent Hackmann, "William Pitt and the Generals: Three Case Studies in the Seven Years' War", Albion: A Quarterly Journal Concerned with British Studies, Vol. 3, No. 3 (Autumn 1971): 128-129.

${ }^{201}$ Quoted in Black, Pitt the Elder, 172 from the Loudoun Papers. 
Southern District] Quarter, on Fort Du Quesne, but at present, it does not appear to me, to be proper to Execute." ${ }^{202}$ Once again, Pitt's first experience at managing North American affairs in 1757 led to drastic alterations in 1758. Loudoun had been allowed tremendous freedom of action and had concentrated his efforts on capturing Louisbourg in the north. Frustrated in his efforts, he had wasted an entire year. Meanwhile, the southern provinces had done nothing to assist in the war effort other than attempting to defend their own borders. The successors to Loudoun received greater direction, and offensive action across the breadth of eastern North America became Pitt's policy.

The experience of 1757 may also have affected the Secretary's perception about the reality of using provincial troops. Possessing perhaps two million subjects, it was assumed that the colonists would play a large part in the execution of the North American conflict. ${ }^{203}$ The Ministry, moreover, assumed that the commitment of royally-funded regular forces would be enough to encourage colonial support. "The King is persuaded," Pitt informed Loudon, "that this His Most Gracious and timely Attention to supply the Body of Troops employed in the Important Service of North America cannot fail to animate the Zeal of all His Subjects there."204 Indeed, such a conception closely mirrored Pitt's political stance on the defense of the British Isles. Prior to Pitt's ascension to the Cabinet, Newcastle's previous ministry had imported German troops to bolster the island's forces. The Secretary's popular opposition to such measures had helped in his battle to reform the nation's militia bill. ${ }^{205}$ Thus, colonial participation in their defense fit closely with Pitt's own domestic policy.

Though provincial support for local defense was generally present, the shift to an offensive strategy in 1758 meant that the colonies would have to agree to send locally raised and funded troops

${ }^{202}$ Pitt's orders to commanders in America can be found in Pitt to Loudon, March 31, 1757, Kimball, Correspondence of Pitt, 1:29 and Pitt to Montgomery, March 31, 1757, Kimball, Correspondence of Pitt, 1:27. Loudon reports to Pitt in Loudon to Pitt, March 10, 1757, Kimball, Correspondence of Pitt, 1:18.

${ }^{203}$ Population estimates come from Reginald Lucas, George II. and His Ministers (London: Arthur L. Humphrey's, 1910), 317.

${ }^{204}$ Pitt to Loudoun, July 18, 1757, Kimball, Correspondence of Pitt, 1:88.

${ }^{205}$ Middleton discusses this debate in Middleton, Bells of Victory, 10. 
beyond their borders, a proposition not readily accepted. In 1757, Virginia had dispatched a small force of two hundred men to South Carolina's defense. ${ }^{206}$ South Carolina as well, raised "a Regiment of Seven Companies of One Hundred Men each, five whereof may be sent to any part of North America."207 Despite these limited concessions, the reaction to sending troops abroad tended to be negative. In Georgia, a colony already deemed under-defended, Governor Ellis sympathetically wrote of his citizens "they really are incapable of doing more than they have done." ${ }^{208}$ Pennsylvania failed to provide the requested troops, leading Loudoun to perceive a nefarious opposition to British authority. "Their whole Attention seems to be," he reported to Pitt, "to usurp every part of the Prerogative, into the hands of the Assembly, and to disappoint every Plan of the Government."209 Perhaps the most recalcitrant, Maryland refused to defend the entirety of its own borders. "[T]hey have ... Voted," an exasperated Loudoun informed Pitt, "That they will allow no Pay, to any Officer that shall Command there [Fort Cumberland], tho' it is in their own Province."210 Maryland's refusal to provide the defense of Fort Cumberland derived from their perception of who benefited from the installation. Located on the colony's far western frontier, the fort actually did more to defend Virginian settlements than it did those of Maryland. Maryland's actions thus demonstrate the extent to which many colonies avoided paying for military necessities that did not directly benefit them. If a successful transition to offensive operations were to be made, the colonists had to be convinced that the measures would directly benefit them. Thus, Pitt's decision to order offensive operations in the Southern District for 1758 likely intended to encourage the recalcitrant southern colonies. The orders to the southern governors for 1758 reflect this intention. "It is unnecessary to add any thing to animate your Zeal," Pitt stated, "in the Execution of His Majesty's Orders on this great Occasion, where the safety and preservation of America

${ }^{206}$ Dinwiddie to Pitt, September 12, 1757, Kimball, Correspondence of Pitt, 1:104.

${ }^{207}$ Lyttleton to Pitt, July 12, 1757, Ibid, 1:86.

${ }^{208}$ Ellis to Pitt, August 1, 1757, Ibid, 1:91.

${ }^{209}$ Loudoun to Pitt, June 17, 1757, Ibid, 1:76-77.

${ }^{210}$ Ibid, 1:77. Governor Sharpe confirmed that this situation remained the case in a letter to Pitt dated October 22, 1757, Ibid, 1:121. 
\& of your own Province in particular, are at stake." ${ }^{211}$ To sweeten the deal, the Secretary dispatched approximately one fourth of the nation's wartime expenditures to North America. ${ }^{212}$

Pitt's plans for 1758 thus differed markedly from those of 1757 . Rather than concede completely to the opinions of his North American Commander-in-Chief, which had resulted in the defensive policy of the Southern District, Pitt took a more active role in the planning. The shift in language proves remarkable. When addressing the southern governors, the Secretary stated "His Majesty considering that the several Provinces, from Pennsylvania inclusive to the Southward, are well able with proper Encouragements to furnish a body of several Thousand Men, [requests them] to join the King's Forces in those parts, for some offensive Operations against the Enemy."213 To that end, Pitt recalled Loudoun to London and promoted General James Abercromby in his place with the express orders to attack Crown Point and Louisbourg. ${ }^{214}$ To the south, the Secretary promoted John Forbes to the rank of 'General in America' with the orders to conduct "any such offensive Operations, as may be judged by Him most expedient for annoying the Enemy, and most efficacious towards removing and repelling the Dangers that threaten the Frontiers of any of the Southern Colonies on the Continent of America." 215 Although Forbes ultimately decided to attack Fort Duquesne, Pitt, influenced by reports of French weakness on the Mississippi River in 1757, ordered Lyttelton to gather intelligence and prepare forces for a projected attempt on French possessions on the Mississippi and Mobile Rivers. ${ }^{216}$ North

\footnotetext{
${ }^{211}$ Pitt to Governors of Pennsylvania Maryland Virginia South Carolina North Carolina, December 30, 1757, Ibid, 1:143.

${ }^{212}$ Estimations of Britain's financial contribution to the North American colonies can be found in Black, Pitt the Elder, 163.

${ }^{213}$ Pitt to Governors of Pennsylvania Maryland Virginia South Carolina North Carolina, December 30, 1757, Kimball Correspondence of Pitt, 1:140.

${ }^{214}$ Hardwicke to Newcastle, December 17, 1758; Newcastle to Pitt, December 27, 1758 in NP, BL, 32876.

${ }^{215}$ Pitt to Abercromby, December 30, 1757, Ibid, 1:146.

${ }^{216}$ Reports about the French strength to the southwest are included in Ellis to Pitt, December 10, 1757, Ibid, 1:130 and Hardy to Pitt, April 10, 1757, Ibid, 1:31; Forbes to Pitt, June 17, 1758 in Irene Stewart, ed., Letters of General John Forbes: Relating to the Expedition Against Fort Duquesne in 1758. Pittsburgh: Allegheny County Committee, 1927, 27; Governor Glens notion of Indian Affairs, ND; Pitt to Forbes, January 27, 1758 in FP, SNA, GD 45/2/40-44. Pitt's orders to Lyttelton are included in Pitt to Lyttelton, January 27, 1758, Ibid, 1:170-171. Despite Pitt's enthusiasm, attacks on the French southwest never materialized.
} 
Americans only abandoned the concept when they concluded that to "attempt any thing on the River

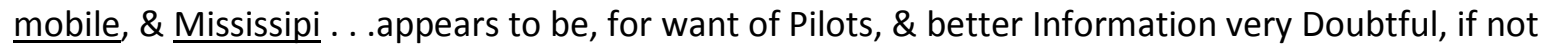
impracticable." ${ }^{217}$ To assure the southern governors that their efforts would not be in vain, he explained to them "the Northern Governments are also directed to raise Men in the same manner, to be employed in such offensive Operations, as the Circumstances \& Situation of the Enemy's Possessions in those parts may point out." ${ }^{218}$ As an added advantage to the multiple offensive strategy, Pitt noted "it is hoped, [it] will oblige them [the French] so to divide their Attention and Forces, as will render the several Attempts more easy and successful."219

His shift from defensive to offensive measures in the Southern District directly addressed the desires of some Britons. Governor Dobbs of North Carolina had for a year desired the "conquering and for ever getting rid of a faithless cruel and perfidious enemy." 220 Writing in 1759, moreover, Horace Walpole commended Pitt for alleviating a nation constantly "dreading invasions from France" by his decision to "turn us into Invaders."221 The success and popularity of Pitt's new policy dictated its continuance until his resignation in $1761 .^{222}$

While Pitt's offensive strategy for 1758 , including the southern campaign, certainly accounted for American conditions, it likewise strengthened his political position in London. Most historians agree that his rise to power was unique for the eighteenth century. Based on popularity rather than court

${ }^{217}$ Boscowan \& Amherst: Resolution, August 8, 1758 in NP, BL, 32882.

218 Pennsylvania Journal, March 15, 1759 quoted in Carol Lynn H Knight, "A Certain Great Commoner: The Political Image of William Pitt, First Earl of Chatham, in the Colonial Press," Proceedings of the American Philosophical Society. Vol. 123, No. 2 (Apr. 27 1979): 71.

${ }^{219}$ Pitt to Governors of Pennsylvania Maryland Virginia South Carolina North Carolina, December 30, 1757, Ibid, 1:142.

${ }^{220}$ Dobbs to Pitt, April 16, 1757, Ibid, 1:33.

${ }^{221}$ John Brook ed., Horace Walpole: Memoirs of King George II, 3 Volumes (New Haven, CT: Yale University Press, 1985), 3:1. Walpole's treatment of Pitt is to be highly valued. Not only is it produced shortly after events described, but it discusses both the strengths and weaknesses of the Secretary in what might be considered an extremely even-handed fashion.

${ }^{222}$ The continuance of Pitt's aggressive policy is discussed in Carol Lynn Homelsky Knight, The Political Image of William Pitt, First Earl of Chatham, in the American Colonial Press, 1756-1778 (PhD dissertation, The College of William and Mary, 1973), 71. 
patronage or intrigue, his legitimacy remained ever tenuous. Only so long as Pitt maintained his popularity 'out of doors', meaning outside of Parliament and government circles, would an unsupportive King George II and an untrusting Newcastle tolerate his presence in a ministry. ${ }^{223}$

The popularity that ushered Pitt into office and made him an indispensable part of any wartime ministry particularly rested on his oppositional oratory directed at the previous Fox-Newcastle ministry's perceived mishandling of the war. The loss of Minorca in 1756 proved especially useful to Pitt's opposition stance. Consequently, his continued popularity rested on military victory. ${ }^{224}$ Walpole recognized Pitt's quandary, noting “his [Pitt's] notions of performing some action of éclat; that might revive our sinking affairs, and throw a luster on the dawn of his own administration."225

One additional consideration influenced the Secretary's aggressiveness in 1758. Newcastle, as First Lord of the Treasury, doubted Britain's ability to finance the expensive conflict after the campaigns of 1758. The longevity of Prussia, Britain's primary Continental ally, had also come under question. Pressured from all sides by Russia, Austria, and France, the Germanic kingdom was under tremendous duress. Consequently, Pitt likely feared that peace might arrive before he achieved the victories necessary to ensure his own political longevity. Additionally, the Secretary needed to seize some possessions from France that might be dealt at the peace table in exchange for the French occupied Minorca and Hanover in an attempt to placate his Whig counterparts without directly involving more British forces on the Continent. ${ }^{226}$ Such considerations illuminate the political factors that led to Pitt's policy "to execute daringly." 227

${ }^{223}$ Discussions of Pitt's unique popularity can be found in Peters, Pitt and Popularity, Black, Pitt the Elder, and Paul Langford, "Pitt and Public Opinion, 1757", The English Historical Review, Vol. 88, No. 346 (January 1973): 54-80.

${ }^{224}$ Discussions of Pitt's opposition can be found in Middleton, Bells of Victory, 50-51; Black, Pitt the Elder, 180; and Peters, Pitt and Popularity, 89.

${ }^{225}$ Brook, Horace Walpole, 2:273.

${ }^{226}$ These considerations are highlighted in Sherrard, Lord Chatham, 256 and Black, Pitt the Elder, 181183.

\footnotetext{
${ }^{227}$ Brook, Horace Walpole, 2:273.
} 
The adoption of multiple offensives, however, placed Pitt in a dangerous position because defeats might be as detrimental as victories could be beneficial to his popularity. The Secretary seemed unconcerned with such possibilities because while defeats might be swept under the rug, victories could be capitalized on in the public sphere. This allowed Pitt to claim credit for victory while shifting the blame for defeat, thus maintaining his popularity.

If Pitt's popularity and political strength relied on military victory, then symbolic victories, those that possessed the power to fire the imagination of the British people, may have been more valuable than ones achieved for purely strategic concerns. A stunning victory on the Ohio River in retribution for the spectacular defeats of Washington and Braddock would provide Pitt with such a victory. Indeed, Richard Middleton suggests just such a motive in Bells of Victory. ${ }^{228}$ Yet, the evidence does not support such a conclusion. Most significantly, Pitt did not specifically order Forbes to seize Fort Duquesne, but rather to conduct "offensive Operations, as shall be judged by the said Commander [Forbes] of His Majesty's Forces in those parts, most expedient for annoying the Enemy, \& most efficacious towards removing \& repelling the Dangers, that threaten the Frontiers of any of the Southern Colonies on the Continent of America." 229 Pitt, therefore, only demanded that Forbes take some offensive action. The General apparently decided on the target.

Additionally, Fort Duquesne would not have been the most likely target for a major symbolic victory. Rather, Louisbourg, which represented a longstanding source of contention between France and Britain, would have been the most obvious choice. Not only had it been the target of Loudoun's unsuccessful efforts of 1757, it had also been the site of Britain's one great triumph during King George's War in the 1740s. The Treaty of Aix-la-Chapelle, which ended the conflict, returned the fortress to

${ }^{228}$ Middleton, Bells of Victory, 54.

${ }^{229}$ Pitt to Governors of Pennsylvania Maryland Virginia South Carolina North Carolina, December 30, 1757, Kimball, Correspondence of Pitt, 1:141. Middleton discusses Forbes connection to Lord Ligonier, Commander-in-Chief, and why Forbes may have been given so much latitude in Bells of Victory, 52-53. 
France. Pitt's orders to Abercromby at the end of 1757 suggest that the Secretary placed a far higher priority on Louisbourg than on Fort Duquesne. While Pitt allowed Forbes wide latitude in the Southern District, his superior received specific directions on the conduct of the war in the north. "[T]he King has come to a Resolution," Pitt informed Abercromby, "to allot an adequete proportion of His Forces in North America, amounting . . . to upwards of Fourteen Thousand Men for the Siege of Louisburg." "230 “I am to signify to You His Majesty's Pleasure," Pitt continued, "that you do cause the several Regiments, so appointed ... for the Siege of Louisburg, to be employed accordingly in that Siege, without making any Change therein." ${ }^{231}$ The specificity of Pitt's orders regarding Louisbourg thus suggests the importance that he placed on the fortress's capture. The "[e]xpedition of the most importance," a correspondent to Newcastle noted in confirmation of Pitt's assumption, "nex to the Louisbourg one, is that against Ticonderoga \& Crown Point."232 In Britain, moreover, it has been argued that popular attention remained focused on Continental affairs, further demonstrating the dubious value of North American victories in general, and victories in the Southern District in particular, as symbolic acts aimed at gaining popularity. ${ }^{233}$ Instead, a southern campaign might be seen as a means for Pitt to solidify his political base with Opposition Whigs and Tories.

The focus of the British public on Continental affairs placed Pitt in a difficult political position, for while his popularity with Britons provided his legitimacy, his political support in Parliament and government circles rested on support from Tories and Opposition Whigs. To placate these supporters, Pitt had to make adequate improvements in the colonial situation, perhaps explaining his aggressiveness in North America beginning in 1758 . While his continued commitments to Europe have led some historians to cite Pitt's hypocrisy, careful consideration of his policies indicates a continued attention to

\footnotetext{
${ }^{230}$ Pitt to Abercromby, December 30, 1757, Kimball, Correspondence of Pitt, 1:143.

${ }^{231}$ Ibid, 1:148.

${ }^{232}$ John Pownall to Newcastle, July 4, 1758 in NP, BL, 32881.

${ }^{233}$ Peters deduces popular interest based on the contents of British periodicals exhaustively researched in
} Pitt and Popularity, 24. 
the demands of his political supporters. When Prussia demanded a greater contribution by Britain, Pitt begged its king, Frederick, to view the conflict in broader terms. ${ }^{234}$ "[T] $]$ he war in America," Pitt had Holdernesse write to Prussia, "will contribute considerably to bring France to reason."235 When the Secretary finally conceded to sending troops to Europe, he made certain to declare that the diversion of manpower would do nothing to diminish his efforts in North America. ${ }^{236}$ Pitt's careful language about Continental commitments suggests a polemical attempt to maintain his Parliamentary support. His actions throughout North America, including the Southern District, may likewise have been directed to the same ends.

Pitt's commitment to North American affairs in general, and the Southern District in particular, also satisfied the naval ideology of his Tory and Opposition Whig supporters. The contentiousness of the naval issue dated back to King George's War (the War of Jenkins's Ear in Europe), when the issue of paying for German mercenaries first arose. In response, opposition groups pushed the 'blue water strategy, in which Britain's navy was deemed the most appropriate instrument with which to combat the nation's enemies. Serving at that time as the Paymaster, it has been suggested that Pitt saw firsthand the underutilization of the Royal Navy. ${ }^{237}$ By the time of the Seven Years' War, Pitt had become a convert. In a speech to the House of Commons in 1761, the Secretary declared, "our marine and colonies should be the principal object.."238 Indeed, Pitt refused an early peace with France in 1761

${ }^{234}$ The background of Pitt's political support and a description of 'country' politics can be found in Ibid, 25-26. Peters additionally suggests that the influence of Beckford, who possessed interests in the West Indies, may have influenced Pitt's actions in America in Ibid, 12. The Honorable Evan Charteris likewise discusses Pitt's commitment to North America in contrast to the Continental policies of the Duke of Cumberland in Even Charteris, William Augustus, Duke of Cumberland and the Seven Years' War (London: Hutchinson \& Co., nd), 248-249. Pitt's appeal to Frederick is described in Sherrard, Lord Chatham, 252.

${ }^{235}$ Holdernesse to Mitchell, February 24, 1758 quoted in Sherrard, Lord Chatham, 253.

${ }^{236}$ Black, Pitt the Elder, 177-178.

${ }^{237}$ For a discussion of the 'Blue Water' strategy, King George's War, and Pitt's experience as Paymaster, see Black, Pitt the Elder, 40, 44, \& 76.

${ }^{238}$ British Library, London quoted in Ibid, 177. 
over the issue of the Newfoundland fisheries citing them as the "[n]ursery for seamen." ${ }^{239}$ The series of coastal raids on France organized by Pitt, such as the aforementioned Rochefort expedition, further suggests Pitt's commitment to a 'Blue Water' strategy. ${ }^{240}$ Governor Dobbs appears to have recognized Pitt's stance, declaring "I know you have the Interest of Commerce and the Safety of our American Colonies so much in your power and at heart.."241 Perhaps preying on the Secretary's conviction, southern governors utilized a naval mentality when seeking assistance. "We can get no Ship stationed on this Province," Dobbs informed Pitt, "which is a Discouragement to our Trade."242 Ellis, apparently fearful that Georgia might be neglected, argued, "[a] Ship of War could nowhere be better stationed for a annoying the Enemy." ${ }^{243}$ Pitt's aggressive, naval and colonial-oriented policies provided one additional advantage. Spain had yet to enter the conflict in 1757 , and he meant to keep it that way if the Spaniards could not be won over to British interests. ${ }^{244}$ To that end, Pitt sent repeated orders to North America attempting to adjudicate Spanish complaints about British privateers, some of them dating as far back as King George's War. ${ }^{245}$ Aggressive action in the Southern District, such as that asked of Forbes, might either convince Spain to enter the war against France or dissuade the Spanish from entering the conflict at all. $^{246}$

${ }^{239}$ Karl W. Schweizer, "William Pitt, Lord Bute, and the Peace Negotiations with France, May-September 1761", Albion: A Quarterly Journal Concerned with British Studies. Vol. 13, No. 3 (Autumn 1981): 268.

${ }^{240}$ Black, Pitt the Elder, 178.

${ }^{241}$ Dobbs to Pitt, December 30, 1757, Kimball, Correspondence of Pitt, 1:154. Dobbs makes a similar statement in Dobbs to Pitt, April 16, 1757, Kimball, Correspondence of Pitt, 1:33-34.

${ }^{242}$ Dobbs to Pitt, December 30, 1757, Ibid, 1:154. Dobbs is here referring to the threat posed by the French navy and privateers.

${ }^{243}$ Ellis to Pitt, August 1, 1757, Ibid, 1:90.

${ }^{244}$ Black discusses an interesting scheme of Pitt's to trade Gibralter to Spain in exchange for that nation's entrance in the war on the side of the British and its assistance in the recapture of Minorca in Pitt the Elder, 89.

${ }^{245}$ See Pitt to Pinfold, August 6, 1757, Kimball, Correspondence of Pitt, 1:94; Pitt to Governors in North America and the West Indies, September 16, 1757, Kimball, Correspondence of Pitt, 1:106; and Pitt to the Governor and Company of Connecticut, January 14, 1758, Kimball, Correspondence of Pitt, 1:161.

${ }^{246}$ In fact, Pitt pursued a plan to capture the French city of New Orleans. Although the plan never took shape, the specificity of Pitt's orders to explore the possibility suggest his heavy interest in the Gulf of Mexico. Such a campaign against New Orleans would have necessitated a neutral Spain. See William Pitt to John Forbes, January 27, 1758, Dalhousie Muniments. 1748-1759, Film 389, David Library of the American Revolution: Philadelphia. 
The Secretary's inattentiveness to the ideologically similar popular faction in Pennsylvania can thus be seen as a calculated political move to retain popular support in Great Britain. While support for the ideologically similar popular faction might have won him support from more intellectual circles within the nation, broad public support might more easily be won from achieving great victories that rallied the nation on an emotional level. The Secretary had ridden these emotions to power by attacking the previous administration's mishandling of the war. Victories overseas, moreover, best served Pitt as a way to extend his support from Tories and Opposition Whigs who viewed Continental measures with suspicion. After failing to grasp the situation in his earlier stint as Secretary of State, Pitt compelled offensive action in 1758, particularly in the Southern military district which had thus far largely operated on the defensive. With its large population, Pennsylvanian support proved critical in the minister's plan, but no target in the province seemed significant enough to Pitt to warrant a campaign. Instead, the Secretary favored an attack, such as one on New Orleans, that might animate the British populace and his political supporters. To accomplish such a feat the southern colonies would have to agree to send its troops abroad. Because doing so proved so unpopular with the populations of those provinces, it remained unlikely that any assembly would concede to such a proposal. As a consequence, any augmentation in the Pennsylvania legislature's power diminished the chances of their participation. Pitt's inaction on behalf of the popular party might thus be seen as an attempt to ensure support for his North American plans.

With authorities in Great Britain reluctant to get involved in Pennsylvania's affairs during the Seven Years' War, the competing political factions continued to clash over issues of liberty and prerogative. Pitt's aggressive southern policy of 1758, however, ensured that new avenues of arbitration emerged. In the form of military officers and Indian agents, the British Empire arrived in Pennsylvania in a tangible manner in the spring of 1758. 


\section{Chapter 3: The British Military and Provincial Authority}

Although both the proprietary and popular factions of Pennsylvania had resorted to appeals to British authorities in London for a resolution to their political dispute, neither received a desirable response. Both factions jealously defended their perceived prerogatives and liberties. The proprietary faction hoped to manage the province without democratic interference from the Assembly. The popular faction, alternately, desired to see proprietary power broken and the emergence of a secure and even more powerful legislature. Both had hoped for a favorable decision from imperial authorities that validated their position and allowed them to seize control of Pennsylvania, but neither wanted to see royal authority interfere directly with the minutia of Pennsylvanian affairs. Pitt's military orders for 1758 , however, led to the dispatch to the province of military officers representing direct royal authority who found themselves compelled to deal with that minutia. When the Secretary assigned General John Forbes to the southern military district, the officer immediately transferred his headquarters from New York City to Philadelphia. Ultimately choosing to attack Fort Duquesne, which the French had built in territory claimed by Pennsylvania, the commander's decision resulted in a flood of British soldiers and officers into the province and required the mobilization of its society to support the subsequent campaign.

Despite this generally unwelcome interference, the military possessed the potential to tip the balance of power. The difficulties of conducting a campaign in North America demanded strong support from colonial soldiers, merchants, and farmers. Although Pitt's directives had technically provided Forbes with broad authority to harness the strength of Britain's colonies, the democratic sentiments and jealous protection of liberty found in the provinces, particularly in Pennsylvania, ensured that the general's claims of royal authority did not compel blind obedience to his requests and directives. Unlike their superiors in London, Forbes and his subordinates quickly discovered that they required the assistance of Pennsylvanian officials and therefore could not ignore local factionalism if they hoped to 
accomplish their task. In exchange for assistance, the general could offer economic and diplomatic favors as well as indirect access to his network of influential patrons. Consequently, a mutually beneficial scenario might have evolved. Forbes required local assistance and those that answered his call could expect preferential treatment which might have proven decisive for one of the factions. Based on the established willingness of both interests to access imperial authorities in Britain when necessary, it stands to reason that this newly arrived agent in the colony would have been aggressively courted as a potential ally in the ongoing political struggle.

Forbes and his officers arrived in Pennsylvania backed by the authority of the King. The general couched many of his orders and requests in language reminding the provincial recipients that his demands equated to demands made by the Crown itself. Colonial officials similarly responded as if they directly served George II. ${ }^{247}$ While this language may seem simply a quaint form of expression, events as late as the mid-1760s suggest how powerful references to the monarchy continued to be. During a particularly vicious series of attacks between Anglicans and Presbyterians following the massacre of friendly Conestoga Indians at Paxton, for example, each went to great lengths to portray the other's members as dissenters. A pamphlet war ensued where each side strenuously defended its loyalty to the Crown. ${ }^{248}$ Religious entities sought to access legitimacy through the Crown more directly by petitioning Forbes during his tenure in the colony.

On July 5, 1758, The humble address of the Members of the Episcopal Churches in the Counties of York \& Cumberland in Pennsylvania informed the general that an armed messenger had on July 2 ordered Reverend Thomas Barton to desist preaching to Pennsylvania's soldiers. In response, the Anglicans asked Forbes "to enquire into this Affair, \& restore us to that care \& satisfaction, which we

\footnotetext{
${ }^{247}$ For examples, see Instructions for the Ohio, March, 1758, FP, GD 45/2/45-52, SNA; Forbes to Dobbs, March 21, 1758; Forbes to Denny, April 21, 1758 in Stewart, Letters of Forbes, 12; Fauquier to Washington, November 4, 1758 in Reese, OPFF, 1:100.

${ }^{248}$ For a more thorough discussion of this conflict, see Bankhurst, "Looking-Glass for Presbyterians," 317 348.
} 
have long enjoy'd under the Ministry of our laborious \& very worthy Teacher."249 The general responded nearly at once, stating that:

You are hereby invited \& authorized to the Discharge of all Ministerial functions belonging to a Clergyman of the Church of England, amongst the Troops under my Command. And all \& sundry, are hereby order'd and requir'd, to pay all due Reverence \& Respect to you \& the Reverend functions you are invested with. And be assured, Sir, that in all places \& at all times, the Clergymen, \& those of the Church of England, shall always be properly encouraged $\&$ protected..$^{250}$

Within three days of being intimidated, Anglicans had made the decision to turn to the proximate British authority to resolve a divisive issue, if only temporarily. For his part, Forbes decisively and clearly exerted his authority within four days-lightning speed in the eighteenth century-to control the situation with what essentially amounts to a fiat order. The actions of Pennsylvanian officers, such as James Burd and John Armstrong, further demonstrate the extent to which the preeminence of royal authority remained a viable motivating tool in mid-eighteenth century Pennsylvania.

At the bequest of William Pitt, Pennsylvania had significantly expanded its military contribution to Britain's war effort in North America in 1758. Fielding three battalions of roughly one thousand men each resulted in the frantic formation of new companies from throughout the province. While the colony raised an impressive number of troops, the quality of both soldiers and officers remained questionable. James Burd, who commanded one battalion of the Pennsylvania Regiment, struggled to form his inexperienced subordinates into an efficient military unit. Through May of 1758 , the colonel remained closely connected to William Denny who, as Governor of the province, represented the source of Burd's and his officers' commissions. As the colonel prodded his officers into moving quicker, getting

${ }^{249}$ The humble address of the Members of the Episcopal Churches in the Counties of York \& Cumberland in Pennsylvania, July 5, 1758, FP, GD 45/2/53-67, SNA.

${ }^{250}$ Forbes to Barton, July 9, 1758 in Stewart, Letters of Forbes, 24. 
organized, and generally acting more professional, and as British officers became more active in the campaign, he increasingly used the shame of disappointing those officers, particularly Forbes's secondin-command, Colonel Henry Bouquet, as a useful motivation. ${ }^{251}$ Burd's gradual shift in his correspondence from language emphasizing Pennsylvanian authority to that highlighting royal authority suggests his growing reliance on British, rather than provincial, connections to fulfill his military obligations.

Similarly, Armstrong spent the majority of the spring and early summer of 1758 attempting to forge the Pennsylvanian soldiers into a reliable military force. The colonel performed tremendous feats of organization, frequently requesting Forbes's advice and support, all while sacrificing his personal connection to his own battalion. ${ }^{252}$ "[M]y inclinations leads me strongly to be with my Battn.," he informed the general, "[b]ut shall in obedience to your desire, stay here [Carlisle] paving the way in the best manner I can." 253 When Armstrong found his provincial soldiers to be "[c]omparatively ignorant of the necessary subjection," as they proved to be on the matter of separating them from their elected officers, he fell back upon the royal authority possessed by Forbes. ${ }^{254}$ "I'm of opinion this piece of duty," he advised Forbes, "will be done with much less risque, that you are personally upon the spot."255 Still, the embattled colonel agreed to push the matter if supported directly by the presence of Sir Allan Maclean, a captain in the Highland regiment, if Forbes could not be present himself. As late as December of 1758, when the campaign progressed towards its conclusion, Armstrong continued to

${ }^{251}$ For examples of Burd's reliance on Denny, see Burd to Denny, April 8, 1758; Burd to Lloyd, May 3, 1758; Burd to Jameson, May 3, 1758; Burd to Shippen, May 3, 1758; Burd to Denny, May 30, 1758 in Shippen Family Papers (hereafter SFP), Vol. H-Col. James Burd Letterbook, 595A, Historical Society of Pennsylvania (hereafter HSP), Philadelphia. For examples of Burd's increasing reliance on British officers, see Burd to Mercer, June 2, 1758; Burd to Gentlemen, July 4, 1758; Burd to Humphreys, July 3, 1758 in SFP, Vol. H-Col. James Burd Letterbook, 595A, HSP; Burd to Sharpe, June 10, 1758, SFP, Vol. H—Col. James Burd Papers, 595A, HSP.

${ }^{252}$ For examples of Armstrong's organizational efforts and interaction with Forbes, see Armstrong to Forbes, June 9, 1758; Armstrong to Forbes, July 2, 1758; Armstrong to Peters, January 16, 1759 in FP, GD 45/2/6887, SNA.

${ }^{253}$ Armstrong to Forbes, June 17, 1758, FP, GD 45/2/68-87, SNA.

${ }^{254}$ Armstrong to Forbes, June 9, 1756, FP, GD 45/2/68-87, SNA.

${ }^{255}$ Ibid. 
apologize to the general for the lack of professionalism within his province's forces. ${ }^{256}$ While Burd and Armstrong utilized the authority of Forbes and his officers to manage the provincial forces for the general good of the service, others appear to have tapped this resource for more personal reasons.

Some Pennsylvanian officers sought Forbes out seeking independent commands. Major George Armstrong, for example, requested permission to take a large force of one hundred provincials on a major probe towards Fort Duquesne on July 12, 1758. A younger brother of Colonel John Armstrong, George had closely observed how his brother's signal 1756 raid on Kittanning, a mostly Delaware village in western Pennsylvania, had propelled him to prominence within the colony's military community. Medals had been struck, and despite the raid's questionable success, the elder Armstrong had been hailed as a savior by many and subsequently became a prominent member of Forbes's military family. George's request, had it been granted, might have further served the family's rise in prominence as well as the major's individual status. ${ }^{257}$

Captain Joseph Shippen extended hospitality to Forbes and benefited directly from forging this connection. On May 8, 1758 Governor Denny had informed the officers commanding Pennsylvania's military forces that Shippen would serve as Brigade Major. In this significant post, the new major assumed the responsibility of coordinating between the various units. Within four days, and through early June, Shippen began issuing orders in the name of the governor and the battalion commanders. ${ }^{258}$

${ }^{256}$ Examples of apologies can be seen in Armstrong to Forbes, December 29, 1758, FP, GD 45/2/68-87, SNA. Among the apologies are items as mundane as the poorness of chimneys constructed by the troops for the dying general's quarters.

${ }^{257}$ George Armstrong to Forbes, July 12, 1758, FP, GD 45/2/68-87, SNA. A larger raid, similar in design to that proposed by Major Armstrong's, was later given to Major James Grant of the Highland Regiment. For a discussion of the raid commanded by the elder Armstrong, see Daniel Barr, "Victory at Kittanning?: Reevaluating the Impact of Armstrong's Raid on the Seven Years' War in Pennsylvania," Pennsylvania Magazine of History and Biography, 141 (January 2007): 1-41.

${ }^{258}$ Shippen's invitation to Forbes is in Shippen to Forbes, January 9, 1759, FP, GD 45/2/97, SNA. While the invitation actually postdates the campaign, it is indicative of the close relationship forged between the two officers. Denny's promotion of Shippen is in Denny, May 8, 1758, SFP, Small Vols., Box 1-7, 595A, HSP. Examples of the major's growing authority can be seen in Shippen to Lloyd, May 12, 1758; Denny to Bull, May 23, 1758; Shippen to the Commanding Officer at Fort Augusta, May 24, 1758; Shippen to Walker, June, 1758 in SFP, 
By July, Forbes had adopted the concept of brigades, and announced the appointment of one each for the British, Pennsylvanian, and Virginian forces. The general elevated Shippen to that post by the sixth of the month. ${ }^{259}$

Forbes expected his brigade majors to attend him at 11:00 a.m. each morning with all the information necessary to coordinate between the three distinct forces. ${ }^{260}$ With the exception of Armstrong, who continued to correspond directly with Forbes into 1759, Shippen managed to establish a near-monopoly on communication with the general by the Pennsylvanian military officers. Using his new authority, Shippen issued orders for troop movements and dictated the command of posts. ${ }^{261} \mathrm{He}$ assigned escort duty and named each day's field officers. ${ }^{262}$ The posting of guards and sentries, the formulation of court-martial boards, and the organization of joint British-Pennsylvanian small-scale operations all fell within the major's purview. ${ }^{263}$ While it remains impossible to know to what extent these orders came directly from the major without Forbes's express approbation, Shippen undoubtedly controlled the information Forbes received from Pennsylvanian officers which dictated the general's subsequent decisions.

Small Vols., Box 1-7, 595A, HSP; Burd to Shippen, June 10, 1758, SFP, Vol. H—Col. James Burd Letterbook, 595A, HSP.

${ }^{259}$ The discussion of brigades is reported in Byrd to Fauquier, July 21, 1758, OPFF, 1:55. Shippen's promotion is announced in Shippen, July 6, 1758, SFP, Small Vols., Box 1-7, 595A, HSP.

${ }^{260}$ This order is listed in General Forbes Orders, July 5, 1758, SFP, Small Vols., Box 1-12, 595A, HSP.

${ }^{261}$ For examples, see Shippen, May 30, 1758; Shippen to Singletary, June 11, 1758; Shippen, June 13, 1758; Shippen, July 4, 1758; Shippen, July 9, 1758; Shippen to Denny, July 9, 1758; Shippen to Montgomery, July 10, 1759; Shippen to Williamson, July 10, 1758; Shippen to Quicksell, July 10, 1758; Shippen to Trump, July 10, 1758; Shippen to Blackwood, July 10, 1758; Shippen to Finley, July 10, 1758; Shippen to Jackson \& Eastburn, July 11, 1758; Shippen to Broadhead, July 11, 1758; Shippen to Orndt, July 18, 1758 in SFP, Small Vols., Box 1-7, 595A, HSP.

${ }^{262}$ For examples see General Orders from Sir John Ligonier, June 26, 1758; Shippen, July 7, 1758; Shippen, July 8, 1758; Shippen, July 10, 1758 in SFP, Small Vols., Box 1-7, 595A, HSP.

${ }^{263}$ For examples, see Shippen, July 1, 1758; Shippen, July 2, 1758; Shippen to Maclean, July 5, 1758 in SFP, Small Vols., Box 1-7, 595A, HSP. 
Correspondence to the general flowed through the brigade major, and he possessed the opportunity to present what he wished and portray the officers how he desired. ${ }^{264}$ Anyone wanting to remain in the good graces of Forbes, therefore, depended on the filtered representations of Shippen. In response to one officer's troubles, for instance, Shippen responded by saying, "I shall transmit your Letters to the General \& when I arrive at Carlisle ... I shall mention their distress to the Commanding officer."265 Beyond this control of information, the major's steady stream of directives, always technically in the name of Forbes but in the hand of and signed by Shippen, took on an authority of their own and could not have failed to impress upon Pennsylvanian officers the importance of the individual dispatching them.

Shippen's newfound significance manifested itself in several ways. In some instances, the major chastised officers for misconduct. "The General therefore commands me to acquaint you," he informed several officers, "that he is extreamly surprized to hear of such Misconduct \& Neglect of Duty, \& is determined to relieve every officer from his Post \& Command for the future." ${ }^{266}$ Once again, it proves difficult to determine the precise origin of the reprimand, whether it actually came from Forbes or if Shippen merely framed in that manner, but the ramifications appear evident. Shippen felt comfortable enough in his position to severely censure his fellow officers, many of whom were senior in age and, prior to his advancement to brigade major, rank. At other times, the major deliberately displayed his commission papers to exert his authority. "I think it absolutely necessary to take [my papers] with me," he informed provincial secretary Richard Peters, "as many Circumstances may require me to ... produce them before the Campaign is over."267 Such a necessity had occurred two months prior, when Shippen immediately assumed command upon his arrival in Lancaster. Finally, and perhaps most significantly,

${ }^{264}$ An example of such a presentation is A Return of His Majesty's Forces under the Command of Brigadier Genearl Forbes, September 25, 1758, SFP, Small Vols., Box 1-7, 595A, HSP.

${ }^{265}$ Shippen to Read, June 23, 1758, SFP, Vol. K-J. Shippen Military Letterbook, 595A, HSP.

266 Shippen to Capt. Montgomery, Lieut. Broadhead \& the other officers who were at Harris's or Fort Hunter, when the above Intelligence arrived there, July 14, 1758, SFP, Small Vols., Box 1-7, 595A, HSP.

${ }^{267}$ Shippen to Peters, August 16, 1758, SFP, Vol. K-J. Shippen Military Letterbook, 595A, HSP. 
the major managed to order supplies from his father, Edward Shippen. ${ }^{268}$ Consequently, Shippen's emergence as the brigade major of the Pennsylvanian forces and the resultant close interaction with Forbes proved significant. The major managed to direct at least modest commerce to his family and undoubtedly made himself an indispensable figure to individuals in the colony seeking access to the general.

Beyond the abstract concept of royal authority, by 1758 the Ministry had backed its North American commanders with tremendous financial resources. Forbes possessed thousands of pounds to spend on the contracting of supplies where, in the highly competitive mercantile markets of Pennsylvania, the general could choose between a wide range of contractors. A military contract, or lack thereof, could literally make or break a firm. ${ }^{269}$ Forbes, moreover, had access to hard currency that proved especially important in the cash-starved province. North American commanders also possessed the authority to place embargos on maritime vessels in order to provide military transports or curb illegal trade with the enemy. As a consequence, those that assisted the general might expect preference for military contracts and protection from the embargo. They might also convince Forbes to deny contracts to commercial rivals and requisition the rivals' ships for military duty, thus damaging or destroying the competition.

Besides the Shippens, other individuals extended hospitality to British officers and invited them into their homes. John Wright, for example, attempted to forge a relationship with Sir John St. Clair, Forbes's Quartermaster General on the campaign. Because St. Clair was the officer primarily in control of purchasing, a connection to him presented tremendous advantages to officeholders such as Wright. Lucrative contracts might be directed to certain regions or individuals while unpopular measures such as

${ }^{268}$ Shippen to Forbes, June 17, 1758; Shippen to Denny, June 19, 1758 in SFP, Vol. K-J. Shippen Military Letterbook, 595A, HSP; Shippen January, June 4, 1758, SFP, Small Vols., Box 1-7, 595A, HSP.

${ }^{269}$ For a very thorough discussion of the importance of military contracts, see Mark Abbot Stern, David Franks: Colonial Merchant (University Park, PA: The Pennsylvania State University Press, 2010). 
wagon impressment or quartering might be redirected. ${ }^{270}$ It remains impossible to ascertain what transpired during these visits, but it seems probable, considering St. Clair's position, that these prominent colonials discussed business during their social visits.

The general also possessed the authority to control diplomatic exchanges with Native Americans. By 1758, the Board of Trade in London had attempted to secure control of such diplomacy by appointing superintendants to represent imperial interests and to provide consistency in dealing with natives. Towards that end, Sir William Johnson and Edmund Atkin had been entrusted with the northern and southern departments, respectively. When Forbes assumed command in 1758, however, the strength of the superintendants remained ambiguous as various colonial governments continued to exert their interests. The generals, however, possessed concrete orders from Pitt to manage Indian affairs in their respective military districts, and these express orders incontrovertibly trumped provincial attempts to conduct independent diplomacy. When the Quaker component of the popular faction relinquished their positions in the Assembly in 1757, many refocused their attacks against the proprietary faction on Indian, rather than legislative, measures. Conflict over the direction of the province's Indian policy thus ensured that Forbes's support became critical. ${ }^{271}$

Beyond Forbes's official authority, he possessed connections to significant patrons in Great Britain whose influence might prove useful to the efforts of the proprietary and popular factions. The general personally understood the value of a strong patronage network. Upon his promotion to an independent command in Pennsylvania and the southern colonies, he immediately became aware of the

${ }^{270}$ Several men named "John Wright" appear in the record. It is unclear whether this particular Wright was an Assemblyman from Lancaster County or a County Justice from Chester County. Based upon the proximity of the counties, and the fact that switching offices was not unheard of, it is also possible that these are the same men. Regardless, a strong relationship with St. Clair was advantageous to either position. For an introduction to John Wright, see Leonard, "Elections in Colonial Pennsylvania," 386; Keller, "Rise of Representation," 143.

${ }^{271}$ For a representation of the powers of North American commanders, see Loudoun to Pitt, March 10, 1757 in Kimball, Correspondence of Pitt, 14-22. 
possibilities of professional advancement. ${ }^{272}$ After a successful stint as quartermaster general in Flanders during the War of Austrian Succession in the 1740s, Forbes found himself in peacetime serving under Lieutenant General Campbell in Northern England. While Campbell enjoyed a relatively comfortable peacetime existence, relying upon his regiment as a source of income, Forbes dealt with the daily regimen of commanding, disciplining, and supplying idle troops as the unit's lieutenant colonel. By all accounts, he performed well in this capacity, making Campbell more than pleased with the arrangement. $^{273}$ Although Forbes distinguished himself as an excellent organizer, opportunities for promotion proved limited due to Campbell's policy of requiring bribes of up to three hundred pounds for advancement. ${ }^{274}$ Forbes ultimately managed to circumvent this impediment by drawing upon the connections he had already formed.

Primarily, Forbes benefited from the patronage of Lords Loudoun, Bedford, and Ligonier. While most British officers jostled for commands on the European continent, where tradition dictated that the important military campaigns occur, Forbes found his opportunity in North America. Serving under Lord Loudoun in New York, the future general commanded the 17th Regiment of Foote. Beyond that, the Commander in Chief entrusted him with the position of Adjutant General, where Forbes once again demonstrated his tremendous organizational skills. ${ }^{275}$ His success in navigating the labyrinth of colonial politics and customs no doubt assisted his major patrons in England as they maneuvered to provide him with augmented responsibilities in North America.

Moreover, the Duke of Bedford became one of Forbes's most active and potentially powerful supporters in Great Britain. Prior to the Seven Years' War, the men made a point to pay their respects

272 Arthur Morris to Forbes, March 9, 1758, FP, GD 45/2/18-21, SNA.

${ }^{273}$ For accounts of Forbes's peacetime service, see George Preston to Forbes, October 5, 1755, FP, GD 45/2/5, SNA; Campbell to Forbes, August 5, 1756, FP, GD 45/2/5, SNA; Campbell to Forbes, October 21, 1756, SNA; \& Return of the Insufficient Accoutrements of the RN: British Dragoons at Blandford, November 1, 1756, FB, GD 45/2/5, SNA.

${ }^{274}$ George Preston to Forbes, February 6, 1755, FP, GD 45/2/5, SNA.

${ }^{275}$ George Rolls to Forbes, September 10, 1757, FP, GD 45/2/18-21, SNA. 
to each other when possible, exchanged compliments through correspondence, and referred to each other as "friend," a term often used in patron/client relationships. Throughout the general's time in North America the Duke strenuously requested a steady correspondence from Forbes. ${ }^{276}$ At the time, Bedford exercised negligible influence in London because the Duke had been exiled to Ireland as its Lieutenant Governor, a position that many British leaders found undesirable. The position, however, functioned as a way for out-of-favor politicians to remain active and connected to events in London while waiting for an opportunity to return to a significant position. Bedford, and presumably Forbes, expected the Duke to eventually regain favor from the King and return to an important position in the ministry. Such a connection would be important for Forbes to cultivate in order to maintain the professional momentum which he had begun to develop through his commands in North America. ${ }^{277}$ However, the recent advancement of Forbes's old patron, Lord Ligonier, proved more immediately important to the general.

Forbes had served as Ligonier's Quartermaster General in Flanders during the War of Austrian Succession, where they reportedly forged a firm working relationship. In North America in 1757, Forbes had developed a similar relationship with his superior, Lord Loudoun, whose recall at the end of the year deprived him of a favorable patron in the military. Ligonier's elevation to the head of the army late that year more than adequately made up for the loss, as he singled Forbes out to the Ministry for independent command. Only Ligonier's fluctuating health threatened Forbes's new access to the highest levels of the British government. ${ }^{278}$ "I pray God he [Ligonier] may last," Forbes's friend George

${ }^{276}$ Campbell to Forbes, February 3, 1757, FP, GD 45/2/5, SNA; Bedford to Forbes, October 24, 1756, FP, GD 45/2/5, SNA; Ross to Forbes, March 11, 1758, FP, GD 45/2/18-21, SNA; Forbes to Bedford, January 20, 1759, FP, GD 45/2/97.

${ }^{277}$ Oxford Dictionary of National Biography, "Russell, John, fourth duke of Bedford," by Martyn J. Powell, accessed July 10, 2011. Bedford did briefly return to prominence during the ministry led by Grenville in the mid-1760s.

${ }^{278}$ George Ross to Forbes, December 30, 1757, FP, GD 45/2/18-21, SNA; Ross to Forbes, January 14, 1758, FP, GD 45/2/18-21, SNA; Ross to Forbes, February 11, 1758, FP, GD 45/2/18-21, SNA; Ross to Forbes, September 15, 1758, FP, GD 45/2/18-21, SNA. 
Ross informed him, "till he has done for you what I am persuaded he has all the inclination in the world for."279 Ligonier ultimately outlived Forbes, and his continued support allowed the general to advance in his profession and forge relationships within the ministry itself.

On May 1, 1758, Forbes directly contacted Secretary of State William Pitt, informing him that “I am directed [by General James Abercromby] to correspond with you, and impart to His Majesty's Ministers the steps that I take ... in the Southern Collonys." ${ }^{280}$ Ross encouraged him to pursue this relationship because the secretary possessed access to both the House of Commons and the chambers of the King. Pitt ultimately brought Forbes to the attention of the House of Commons and the King for preferment, demonstrating that the relationship had blossomed. ${ }^{281}$ As Forbes's health deteriorated during his campaign, he increasingly fretted about his future and came to rely on Pitt's goodwill to ensure his position. ${ }^{282}$ In a letter written to Pitt less than two months before his death, the general appealed to the Secretary, stating:

Had I ever committed any fault, or been guilty of any misdemeanor in the Service, I should be now ashamed of making this Application [to assume his old rank back in England] to you, but the having so many people put over my head, without my being sensible of any faux pas committed, has made and still makes the deepest impression on my mind. If Lord Ligoneir pleases to let you know the hardness of my case, I flatter myself with the protection and Service of Mr. Pitt, to restore me to Peace of mind. ${ }^{283}$

Forbes clearly demonstrated his fealty to his principle benefactors, naming the forts he constructed Bedford, Ligonier, and Pitt successively, and making sure to inform the men of his actions.

${ }^{279}$ George Ross to Forbes, April 8, 1758, FP, GD 45/2/18-21, SNA.

${ }^{280}$ Forbes to Pitt, May 1, 1758, in Stewart, Letters of Forbes, 13.

${ }^{281}$ Ross to Forbes, January 9, 1758, FP, GD 45/2/18-21, SNA; Ross to Forbes, November 11, 1758, FP, GD 45/2/18-21, SNA; Ross to Forbes, December 9, 1758, FP, GD 45/2/18-21, SNA. $\& 74$.

${ }^{282}$ Forbes to Pitt, September 6, 1758 and Forbes to Pitt January 21, 1759 in Stewart, Letters of Forbes, 37

${ }^{283}$ Forbes to Pitt, January 21, 1758 in Stewart, Letters of Forbes, 74. 
When Forbes arrived in Pennsylvania in 1758, the traditional British system of military patronage had already ingrained itself in North America. Families actively engaged persons in positions of power to seek positions of preferment for their children, individual officers campaigned vigorously for commands, and even the highest ministers in the cabinet sought to satisfy the demands of petitioners whose assistance might later be called upon. ${ }^{284}$ During his years in the colonies, Forbes himself received multiple queries, ranging from requests for military commissions, offers to serve as the general's personal physician, and requests for preferment from powerful parties in Great Britain. ${ }^{285}$ For example, Arthur Morris requested that Forbes commission a man named Christopher to a position as a supply purchaser, and Burd asked the general for a recommendation to Denny for James Dunlop, who had served as a scout on Forbes's expedition. William Forster wrote to Forbes requesting advancement for his nephew currently serving as a volunteer in the Royal American Regiment. A Mr. Hoops, serving as a contractor for the military, utilized his access to Colonel Bouquet to seek assistance for both his son-in-law, Daniel Clark, and his nephew, who had been imprisoned during an altercation with a fellow officer. Both the elder Shippen and Dr. Ross, prominent members of Pennsylvanian society, sought favors from Bouquet and Forbes. Additionally, Conrad Weiser, a significant supporter of the proprietary interest, could "not help of Recomending my dear Son Samy to your [Bouquet's] patnernal care." ${ }^{286}$ Of note, Forbes's own family members, many of whom suffered from severe financial stress during the period of the general's advancement in North America, proved his most

\footnotetext{
${ }^{284}$ For examples of families seeking patronage, see Rutherford to Newcastle, December 21, 1757, NP, 32876, BL; Alex Wedderburn to John Forbes, October 8, 1758, Forbes Papers, GD 45/2/53-67, SNA; John Forbes to William Pitt, January 21, 1759 in Stewart, Letters of Forbes, 73. For examples of individual officers seeking patronage, see Murray to Ligonier, undated, NP, MSS 32877, BL; Admiral Knowles to Newcastle, December 30, 1757, NP, MSS 32876, BL. For an example of ministers seeking patronage, see Newcastle to Ligonier, December 10, 1757, NP, MSS 32876, BL.

${ }^{285}$ William Hepburn to John Forbes, February 12, 1757, FP, GD 45/2/5, SNA; Masterton to John Forbes, January 5, 1758, FP, GD 45/2/32/1-39B, SNA; Sam Macleane to Forbes, January 22, 1759, FP, GD 45/2/97, SNA.

${ }^{286}$ Weiser to Bouquet, June 14, 1758 in Stevens, Papers of Bouquet, 2:91.
} 
frequent petitioners. During his two years in North America, they contacted him no less than seven times seeking assistance. ${ }^{287}$

Apparently, Forbes's increasing access to important figures in the British government and military offered a potential boon to his struggling relatives and Pennsylvanian acquaintances, and it might also serve the interests of local factions who had earned the general's favor. Powerful entities in Britain, such as the Secretary of State and the Board of Trade, officially possessed the authority to appoint a variety of low level positions in most colonies, but many frequently ignored the less prominent posts, leaving them to be determined in the colonies. The selection of these officers had been one of the sources of friction between Pennsylvania's political factions. If assistance rendered to Forbes proved adequate, he might be expected to use his growing connections in Britain to request the appointment of his supporters to those previously-overlooked positions. ${ }^{288}$

No amount of flattery could substitute for success, and the general knew this fact early in his expedition. Ross had indicated the importance of providing his patrons with the ammunition to support the general's repeated applications for assistance. "[S]omething must be done," Ross informed him, "to give [Ligonier] an opportunity of serving you in the closet." "[I]f we have success this campaign," Ross further informed Forbes, "[t]he Secry of States power will be considerably augmented." 289 Despite the benefit the general's success lent to Ligonier and Pitt in the political circles in London, their patronage ultimately meant very little to Forbes's chance of succeeding during the spring of 1758 as he struggled to manage "[t]he Army that I have the honour to Command composed of raw undisciplined troops,

${ }^{287}$ Hoops to Bouquet, June 9, 1758, 2:59, Hoops to Bouquet, June 10, 1758, 2:66-67, Shippen to Bouquet, June 9, 1758, 2:63; Bouquet to Forbes, June 14, 1758, 2:88 in ibid; John Forbes to William Graham, Bond of Relief, undated, FP, GD 45/17/1124, SNA; John Forbes to John Forbes, undated, FP, GD 45/21/97, SNA; John Forbes to John Forbes, February 14, 1757, FP, GD 45/2/5, SNA; Thomas Glen to John Forbes, March 22, 1758, FP, GD 45/2/40A-76, SNA; Hugh Forbes to John Forbes, April 16, 1758, FP, GD 45/2/97, SNA; Thomas Forbes to John Forbes, April 17, 1758, FP, GD 45/2/97, SNA; Barrington to John Forbes, October 17, 1758, FP, GD 45/2/5, SNA. ${ }^{288}$ For a more detailed discussion of patronage in the colonies, see Haffenden, "Colonial Appointments."

${ }^{289}$ Ross to Forbes, May 13, 1758, FP, GD 45/2/18-21, SNA. 
Officer and Soldier, newly raised and collected from all parts of the Globe, from the Highlands of Scotland, Germany \&c to South Carolina with this variety of minds gathered together."290

To be victorious and generate increased support from patrons, Forbes needed to harness the strength of this wild assortment of characters and successfully supply such a large force and keep it in the field. Despite his talent for organization, the general found this task overwhelming. ${ }^{291}$ "I assure you for my own part no Serjeant or Quarter Mr of a Regiment is oblidged to look into the small detail more than I am," he confided to Bouquet, "and find that if I did not see the execution of things myself, we should never gett out of this town [Philadelphia]." ${ }^{292}$ To get the campaign moving, he desperately needed support from friends in the colonies.

Forbes and his officers thus turned to a wide-ranging assortment of characters to advance the service. Throughout the campaign, the general worked closely with Governor William Denny and the elected Assembly, but he and his subordinates concurrently sought assistance directly from local officials, expecting them to "exert your Authority." 293 In a flurry of letters, Forbes and Bouquet petitioned justices, commissioners, constables, sheriffs, and magistrates to prod Pennsylvania's populace into action and support the expedition. ${ }^{294}$ Beyond these official channels, the British commanders additionally relied upon influential members of Pennsylvanian society to assist them in advancing their efforts. ${ }^{295}$ "I depend, therefore, on your Assistance, to spirit up the People of York County, where, I know, you have, a great influence," Bouquet informed George Stevenson, "and make them Sensible of the necessity of exerting themselves for the Success of this Expedition upon which, the

${ }^{290}$ Forbes to Fauquier, November 5, 1758 in Reese, OPFF, 1:102.

${ }^{291}$ Bouquet to Forbes, June 7, 1758, 2:47, Bouquet to Forbes, June 14, 1758, 2:89; Forbes to Bouquet, June 16, 1758, in Stevens, Papers of Bouquet, 2:103.

${ }^{292}$ Forbes to Bouquet, June 10, 1758 in ibid, 2:64.

${ }^{293}$ Bouquet to Matistrates of Berks County, June 5, 1758 in ibid, 2:32.

${ }^{294}$ Shippen to Bouquet, June 9, 1758, 2:63, Bouquet to Shippen, June 3, 1758, 2:26, Shippen to Bouquet, June 4, 1758, 2:30-31; Bouquet to Forbes, June 11, 1758, 2:72 in ibid.

${ }^{295}$ Bouquet to Weiser, June 5, 1758, 2:33, Shippen to Bouquet, June 9, 1758, 2:63, Billings to Bouquet, June 9, 1758, 2:57; Hoops to Bouquet, June 10, 1758, 2:66 in ibid. 
very being of this Province depends." 296 In a similar exchange, Bouquet requested that Shippen "take the most vigorous Measures to recall your People to their duty, \& true Interest." 297 Support from such men, as well as that from public officials, became critical as Pennsylvanians increasingly demonstrated an unwillingness to support the campaign.

Despite Forbes's possession of royal authority and the apparent advantages of working with him, many Pennsylvanians chose to emphasize the power of individual and local authority and eschewed those advantages. Some junior officers, for example, at times refused to comply with orders. ${ }^{298}$ The enlisted men, moreover, resisted what they considered to be unreasonable or unacceptable demands. In May of 1758, MacLean reported to Forbes that three companies from York County "declined" to obey an order from Bouquet to provide escorts for advancing supplies. ${ }^{299}$ The following month, Shippen reported a similar interaction where provincial levies refused an order because they thought it "very unreasonable." ${ }^{300}$ In the cases reported by MacLean and Shippen, the failure of British and Pennsylvanian authorities to adequately equip the levies caused the unrest. In other instances, the colonists simply ignored orders that separated them from the units and commanders with which they had agreed to serve. ${ }^{301}$ The manner in which some Pennsylvanian officers and enlisted men willingly disregarded orders proves significant. These men demonstrated no blind acquiescence to abstract concepts of royal authority, but instead exerted their individual power and negotiated what they believed to be reasonable orders and terms of service. Interestingly, this same mentality appears in the reactions of the civilian population to the demands of the Crown and the colony during the campaign.

\footnotetext{
${ }^{296}$ Bouquet to George Stevenson, June 3, 1758 in ibid, 2:27.

${ }^{297}$ Bouquet to Shippen, June 3, 1758 in ibid, 2:26.

${ }^{298}$ Burd to Hughs, May 16, 1758, SFP, Vol. H-Col. James Burd Letterbook, 595A, HSP; Shippen to Halket, June 23, 1758, SFP, Vol. K-J. Shippen Military Letterbook, 595A, HSP.

${ }^{299}$ MacLean to Forbes, May 29, 1758, FP, GD 45/2/37-39, SNA.

${ }^{300}$ Shippen to Armstrong, June 15, 1758, SFP, Vol. K-J. Shippen Military Letterbook, 595A, HSP.

${ }^{301}$ Fauquier to Washington, June 25, 1758 in Reese, Papers of Fauquier, 1:42.
} 
When Forbes began organizing his expedition to the Ohio River Valley in March of 1758, he immediately became aware of the central importance of colonial wagons in supplying his military endeavors. The same had been true of other North American campaigns, including the failed attempt by General Edward Braddock three years earlier. It was partly due to the potential of Pennsylvania to satisfy this critical need, and to the fact that Benjamin Franklin had so timely delivered wagons to Braddock's effort that Forbes chose the province over Virginia and Maryland as the base of his operations. The response of Pennsylvania's farmers, however, further demonstrates the unwillingness of colonists to serve British authority under any terms other than their own. ${ }^{302}$

From the general's point of view, extremely generous terms had been offered for horses and wagons. He paid the farmers well for both the weight carried and the distance travelled, he did his best to provide forage for the animals, and he protected the drivers from any perceived abuse from his British and colonial officers. ${ }^{303}$ Forbes ultimately concluded that "the price I pay and the treatment the Waggoners and horses meet with deserves a better return from the Inhabitants, than they have as yet shown. ${ }^{\prime 304}$ Not only did farmers fail to offer horses and wagons in the numbers needed by the general, but those that did accept contracts insisted upon clear parameters within which they agreed to serve. As MacLean informed Forbes:

[T]he people of that county [York] object to employing their Horses or wagons in hauling provisions to the Frontier garrisons, till they have first entered into a formall Contract wt [with] some deputy regularly appointed by your Excellency, They insist likewise to be paid by apprisement if any of their Horses or wagons happen to be lost in the service, whether by the Enemy or otherwise. ${ }^{305}$

\footnotetext{
${ }^{302}$ Forbes to Peters, August 28, 1758 in Stewart, Letters of Forbes, 31.

${ }^{303}$ Forbes to Denny, September 9, 1758 in Stewart, Letters of Forbes, 39-40.

${ }^{304}$ Forbes to Peters, August 28, 1758 in Stewart, Letters of Forbes, 31.

${ }^{305}$ Maclean to Forbes, May 29, 1758, FP, GD 45/2/37-39, SNA.
} 
Forbes worked hard to satisfy these demands, selecting respected wagon masters responsible for the campaign's logistical operations. Yet despite these concessions, the general continued to experience difficulties with the headstrong farmers. Upon entering into a contract, the drivers tenaciously stuck to the terms, regardless of shifting affairs and necessities. When contracts stipulated delivery to specific outposts, drivers resisted being diverted or having their distances increased, regardless of any concurrent increase in payment. In a frustrated message to Peters in Philadelphia, Forbes reported that "one foot further they will not move, so I am drove to the necessity of persuading them to move forward in the military way, but still paying them in proportion." ${ }^{306}$ British officers increasingly favored adopting this "military way" in coercing provincial support. While Forbes entertained the idea, he preferred to allow local civilian authority to resolve the issue if possible.

Immediately upon assuming command in March of 1758, Forbes informed Governor Denny that he desired press warrants for the purpose of acquiring the necessary transport for his upcoming expedition. "In order that if you are not vested with the Power to grant such Warrants," he stated, "you will apply to the Assembly to grant theirs." ${ }^{307}$ The Assembly dragged its feet on issuing the warrants, and Forbes continued to work with the legislature as late as September. He additionally contacted county officials, asking them to provide assistance. Here, too, the general met with silence. ${ }^{308}$ Exasperated, Forbes conceded to realities and threatened to exert his royal authority to resolve the issue. In early September, he warned Denny:

I should be sorry to employ him [St. Clair] in exercising any Violent Measures, which the Exigency of Affairs I am in at present must Compel me to do, if I am not relieved by a speedy Law for the Providing the Army with Carriages, or a general Concurrence of

${ }^{306}$ Forbes to Peters, October 16, 1758 in Stewart, Letters of Forbes, 57.

${ }^{307}$ Forbes to Denny, March 23, 1758 in ibid, 10.

${ }^{308}$ Forbes to Denny, September 9, 1758 in Stewart, Letters of Forbes, 40-41; St. Clair to Nelson, October 6, 1758, FP, GD 45/2/53-67, SNA. 
Magistrates and People of power of those Provinces in assisting, to their utmost, to provide the same ... I attempted to do without even being obliged to impress any Carriages . . if the Inhabitants who have Waggons are not obliged to furnish a Sufficient Number of them ... [I] shall be Obliged to draw off my Master's Forces to the Inhabited Parts of the Country, and take Provisions and Carriages wherever they can be found...

The Evil which will Attend this Procedure is, that the Innocent must Suffer with the Guilty. $^{309}$

The ramifications of Forbes's message appear evident-military force, backed by the general's royal authority, would be used to procure wagons if local and provincial institutions failed to act. Members of the proprietary interests scrambled to comply in light of the failure of the counties and Assembly to do so. Writing to William Allen, Chief Justice of Pennsylvania's Supreme Court, Burd reported that in his opinion, “[p]ressing of Waggons and Horses ... distresses the Inhabit. And does not answer the Purpose nigh so well as the ... Law." Burd continued by admonishing the justice to rally the "leading men of our Province" to work with the general to formulate an alternative solution. ${ }^{310}$ By the winter, St. Clair had done just that, forging relationships with influential men to scrape together the necessary transport. ${ }^{311}$ In other areas as well, Forbes and his subordinates acutely experienced this lack of support from officials and legislators. On the local level, the military relied on officials to perform a variety of tasks, including the supervision of supply to the rearward fortifications, the capture and return of deserters, the quartering of troops, and the acquisition of wagons. ${ }^{312}$ Yet, at nearly every turn, British officers ran into difficulties and an abject lack of cooperation from the "troublesome commissioners." 313 They

${ }^{309}$ Forbes to Denny, September 9, 1758 in Letters of Forbes, 39.

${ }^{310}$ Burd to Allen, September 13, 1758, SFP, Vol. H-Col. James Burd Letterbook, 595A, HSP.

${ }^{311}$ St. Clair to Forbes, December 1758, FP, GD 45/2/22-31, SNA.

${ }^{312}$ Charles Moore to Forbes, July 7, 1758, FP, GD 45/2/53-67, SNA; Burd to Patterson, April 26, 1758, SFP, Vol. H-Burd Letterbook, 595A, HSP; Loudoun to Commanding Officer of the $22^{\text {nd }}$ Regiment of Foot, November 17, 1757, FP, GD 45/2/18-21, SNA.

${ }^{313}$ Napier to Forbes, June 19, 1758, FP, GD 45/2/37-39, SNA. 
routinely failed to perform the services requested of them and at times possessed the impertinence to lecture the Governor about monetary matters. ${ }^{314}$ The response of one local official from Chester County to a British request for the apprehension of rioters clearly demonstrates the difficulties faced by these men. "[H]e read about ten lines of their Letter," an officer informed Forbes, "and told me with a groan, that he was sorry the Circumstances of his Family were such that he could not grant a warrant." ${ }^{315}$ In this instance, the officer contracted an attorney to compel the man "to do his Duty." ${ }^{\prime 16}$ The elected legislators in the Assembly compounded the military's effort to support the campaign by consistently meddling in the affairs of its provincial troops, failing to compel its local officials to act, and generally pursuing measures that proved popular with the province's citizens rather than conducive to a successful expedition. ${ }^{317}$

To combat the frustrating interactions with local officials and assemblymen, the general maintained a steady correspondence with the governors, as he had with regards to the wagon issue, in hopes that they might be of assistance. ${ }^{318}$ To Francis Fauquier, governor of Virginia, Forbes described his situation, saying "the task that I am employed in not only extremely difficult in the execution but also extreamly precarious in the success therefore you may very easily believe that I am willing to Grasp at every advice that can give me the smallest insight into the Situation of my own affairs." ${ }^{319}$ Fauquier responded with an admission of impotency, explaining:

${ }^{314}$ Shippen to Forbes, June 12, 1758, SFP, Vol. K-Joseph Shippen Military Letterbook, 595A, HSP; Forbes to Pitt, May 18, 1758 in Stewart, Letters of Forbes, 19.

${ }^{315}$ Charles Cruikshank to Forbes, February 12, 1758, FP, GD 45/2/32/40A-76, SNA.

316 Ibid.

${ }^{317}$ For discussions about the Assembly, see Johnson, "What Must Poor People Do?," 118; Leonard, "Elections in Colonial Pennsylvania," 387. Not surprisingly, the legislatures of Virginia and North Carolina treated Forbes with a similar lack of support. See Dobbs to Forbes, April 12, 1758, FP, GD 45/2/53-67; Fauquier to Board of Trade, June 28, 1758; Byrd to Fauquier, July 21, 1758; Fauquier to Washington, September 16, 1758; Fauquier to Forbes, October 19, 1758; Fauquier to Washington, November 4, 1758; Fauquier to Byrd, November 12, 1758;

Fauquier to John Buchanon, November 14, 1758 in Reese, OPFF.

${ }^{318}$ Examples of such requests can be found in Forbes to Denny, March 20, 1758; Forbes to Denny, April 28, 1758; Forbes to Denny September 9, 1758 in Stewart, Letters of Forbes; Forbes to Fauquier, October 9, 1758; Forbes to Fauquier, October 22, 1758; Forbes to Fauquier, November 5, 1758 in Reese, OPFF.

${ }^{319}$ Forbes to Fauquier, November 5, 1758 in Reese, OPFF, 1:102-103. 
I dare say as private Gentlemen We shall generally be of the same Opinion, both having the same Object in View; whereas if we write under our public Characters, We are both as I apprehend under some kind of Restraint. I am sure for my self I am obligd from Duty, to express the Sentiments of this Colony, tho' they should not exactly tally with my Own. ${ }^{320}$

Fauquier's comments ultimately summarized Forbes's reality. Almost without exception, colonial institutions of political authority failed the general while catering to the popular interests of citizens over the greater good of the empire.

When Forbes reported his difficulties to his superior, Secretary of State Pitt, he essentially blamed the situation on "contrary factions." 321 Bouquet's assessment concurred with that of Forbes, as evidenced by his statement to Stevenson where he wished that Pennsylvanians might "set aside all Party's and Dissentions, and unanimously and Chearfully Join their best endeavours, to ours [Britain's]." ${ }^{322}$ On at least several occasions, Pennsylvanians further corroborated Forbes's suspicion. According to Weiser, "[w]e have a Set of people here that will not only do nothing, in this affair, but by their Example and III will, puts Mischief into others." Deeply connected to the proprietary faction, Weisar continued by suggesting that Quaker influence was responsible for this recalcitrance, saying "I am much Concerned for the backwardness of Some our Religious people/as they pretent to be/ and hope their III behaviour will not be Imputed to the whole Country." ${ }^{323}$ The younger Shippen concurred, noting that "[t]his grumbling [about wagons] I am apt to think proceeded only from some few ill disposed people." ${ }^{324}$ Similar to Weiser, the elder Shippen attempted to cast the blame on his political enemies, informing Bouquet that "I am equally astonished with You, (and very much ashamed) to think

\footnotetext{
${ }^{320}$ Fauquier to Forbes, November 19, 1758 in Reese, OPFF, 1:107.

${ }^{321}$ Forbes to Pitt, September 6, 1748 in Stewart, Letters of Forbes, 37.

${ }^{322}$ Bouquet to Stephenson, June 3, 1758 in Stevens, Bouquet Papers, 2:27.

${ }^{323}$ Weiser to Bouquet, June 14, 1758 in ibid, 2:90.

${ }^{324}$ Shippen to Bouquet, June 4, 1758 in ibid, 2:31.
} 
that every body does not Study their own Interest more on So important an affair, as the fate of America seems to depend much upon the success of these present Campaigns." ${ }^{325}$ Bouquet, in fact, came to believe that much of the unrest about the wagons resulted from people misrepresenting, perhaps with the intent of stirring up anger against the military presence, the terms offered by the military. "I26 "I am rather Inclin'd to think," he mused, "that the nature of this Affair [of the wagons] has not been properly explained to them [the people]. ${ }^{\prime 327}$

The evidence does strongly suggest that the pre-existing ideological leanings of Pennsylvanians significantly colored their response to the military. Those who supported the popular faction did so because they opposed what they perceived to be tyrannical behavior by the proprietors and their agents in Pennsylvania. In their view, the proprietary faction favored hierarchy and oligarchy at the expense of local liberty, independence, and democracy. In 1758, the actions of Forbes and his officers appeared similarly motivated to many colonists in the province. The experience of Germanic migrants in Europe had certainly hardened their view of standing militaries, and those connected to the British Isles by tradition or direct migration possessed similar sentiments. If colonial antipathy towards the standing militaries had resulted from the arrogance of its officers and the heavy-handed nature of their actions, wartime measures issued through the medium of trusted and respected local officials should have proved more palatable to the colonists. Yet the evidence from Pennsylvania does not support this. The actions of Forbes did appear heavy-handed to many Pennsylvanians, and his officers could act with incredible arrogance. ${ }^{328}$ Yet the general attempted whenever possible to work within the

${ }^{325}$ Shippen to Bouquet, June 9, 1758 in ibid, 2:63.

${ }^{326}$ Bouquet to Forbes, June 3, 1758 in ibid, 2:18.

${ }^{327}$ Bouquet to Stephenson, June 3, 1758 in ibid, 2:28.

${ }^{328}$ For examples of British arrogance towards their colonial counterparts, see Shippen, July 11, 1758; Shippen July 15, 1758 in SFP, Small Vols., Box 1-7, 595A, HSP; James Grant to Forbes, August 21, 1758, FP, GD 45/2/53-67, SNA. For examples of the heavy-handed nature of Forbes's command, particularly applied to his treatment of provincial deserters, many of whom were flogged and some of whom were killed in the process of capture, see Burd to Patterson, May 14, 1758, SFP, Vol. H-Col. James Burd Letterbook, 595A, HSP; General Forbes Orders, July 5, 1758, SFP, Small Vols., Box 1-12, 595A, HSP; Journal of Joseph Shippen, 1758, SFP, Small 
Pennsylvanian political structure, seeking support and assistance from the Assembly and local officials.

The groan issued from the Chester County official when petitioned by the military to arrest a local deserter thus suggests the true nature of the popular Pennsylvanian rejection of the British military: many citizens opposed anything that resembled tyrannical, hierarchal, or oligarchical authority, regardless of the origins, be they imperial, provincial, or even local. Local government had proved so popular precisely because it had appeared receptive and responsible to the people, but the reaction of the Chester County official indicates that this relationship would have lapsed had the localities acted similarly to the proprietors or military. Bouquet recognized this reality, concluding to Forbes that " $\mathrm{t}] \mathrm{he}$ truth of all this is that every one wishes to be popular, and build his career at the expense of the government." 329

The military had found itself confronted by a society lacking in the necessary deference to render its claims of royal authority meaningful. ${ }^{330}$ Instead, it had to cope with local officials intent on maintaining their electoral popularity, regardless of any personal desire to advance the campaign. Thus, the displeasure of many Pennsylvanians in 1758 must be considered a much deeper ideological issue. Rather than a simple reaction to the actions of the military, the hostility derived from the perception of what the military represented in the eyes of the people: a tool of hierarchal authority in the same vein as the proprietary agents in Pennsylvania. ${ }^{331}$

Vols., Box 1-7, 595A, HSP; Shippen, July 12, 1758, SFP, Small Vols., Box 1-7, 595A, HSP; Shippen, July 13, 1758, SFP, Small Vols., Box 1-7, HSP; Minutes of a Court of Inquiry, June 3, 1758; John Rogers, July 12, 1758; At a Court of Inquiry held by Order of Coll Bouquet, at Fort Bedford, January 20, 1759 in FP, GD 45/2/53-67, SNA.

${ }^{329}$ Bouquet to Forbes, June 3, 1758 in Stevens, Bouquet Papers, 2:18.

${ }^{330}$ For discussions of this lack of deference, see McCoy, "Barbarian Philosophe," 239; Andrew R. Murphey, Conscience and Community: Revisiting Toleration and Religious Dissent in Early Modern England and America (University Park: PA: The Pennsylvania State University, 2001); Gregory T. Knouff, The Soldier's Revolution: Pennsylvanians in Arms and the Forging of American Identity (University Park, PA: Pennsylvania State University Press, 2004).

${ }^{331}$ Both Leach and Dixon do address ideological motivations for the opposition to the British military in North America. Subsequently, however, Leach almost exclusively addresses the role that interaction between the two groups played in the development of this relationship. Brodine does not address the ideological issue. For a deeper discussion of colonial ideologies during this period and beyond, see Bailyn, Ideological Origins of the American Revolution. 
While those inclined to support the popular faction recoiled at the actions and demands of the British military, members of the proprietary faction appear to have generally embraced its presence. Individuals sought economic advantage and provincial officers sought to please their royal counterparts. At the same time, however, an organized effort to utilize British agents of imperial authority to combat their political competitors does not seem to have developed. While it remains impossible to determine the extent of private conversations held between Forbes and his petitioners during his lengthy stay in Philadelphia, no paper trail exists to suggest that proprietary supporters directly appealed for assistance against the popular faction's dominance over the legislative branch of the government. In the end, it seems that despite his authority, patronage, and resources, Forbes did not elicit high hopes from the faction to introduce any immediate change. Multiple factors support this conclusion.

First, despite Forbes's rhetoric and direct connection to royal authority, practical realities in Pennsylvania rendered the general's powers abstract rather than concrete. Reflecting this reality, Bouquet blasted Pennsylvanians in a fit of frustration, writing " $[\mathrm{t}] \mathrm{his}$ is very hard for me, and I do not know how your People will answer for the Consequences." ${ }^{332}$ Describing a comparable situation in Virginia, Governor Fauquier identified a similar issue, informing St. Clair that "we cannot compel them [the people]." ${ }^{333}$ Although a decade after Forbes's successful expedition colonists and British authorities locked themselves into a struggle to define their relationship, the issues raised in those debates of the 1760 s and 1770 s appear present in the 1750 s. $^{334}$

Thus, on the one hand Forbes utilized strong language referencing the authority of the Crown as well as threats of force against Pennsylvanian citizens, while simultaneously using language that indicates his dependence on the "spirit and zeal for the Honour of the King and good of his Country"

${ }^{332}$ Bouquet to Shippen, June 3, 1758 in Stevens, Bouquet Papers, 2:26.

${ }^{333}$ Fauquier to St. Clair, June 6, 1758 in Reese, OPFF, 1:16.

${ }^{334}$ Haffenden addresses this conversation in "Colonial Appointments," 418. He states "Whether the old colonial system was held to be based on authority or contract, its effective working as a system depended in large measure on the respect which colonists were prepared to give the central government and its measures." 
amongst the citizens to support his advance. ${ }^{335}$ Thus, when Forbes attempted to exert his authority he found himself reduced to using only strong language, threats, or idealistic references to the Crown. "I hope the Province will make no difficulty, as to the Expence," he informed Peters, "as it will be a most monsterous reflection upon them if they do, and they never after can either look for, or expect the favour or protection of Great Brittain." ${ }^{336}$ In reality, however, the general proved practically impotent in the face of the democratic sentiments of the local peoples he relied upon. Several examples clearly demonstrate his lack of authority to dictate to the citizens of Pennsylvania.

When dealing with the civilian populace, the military went to great lengths to convince, rather than coerce, support for his campaign. The program first entailed smoothing over all past difficulties. "If you know of any real Hardships that some of your Province has Sufferred by Accident or otherwise in the Service," Bouquet informed Stephenson, "[p]lease to let a Just and clear Representation be drawn up, and sent to me, and I will lay it before the Generals, who I am Persuaded will pay due regard to it." ${ }^{337}$ Upon learning of some of these "hardships," the colonel immediately advised Forbes to "find some way of paying ... the cost of that cursed horse which was drowned last year in the service of the second battalion of the R.A. That will have a very good effect, and will smooth over many difficulties." ${ }^{338}$ The second part of Forbes's solution to the wagon issue had been, despite his threats of impressment, the adoption of a system of contracting that meticulously respected the terms farmers proved willing to engage in. Often this meant that the wagons would only carry provisions to a predetermined point. ${ }^{339}$ "I am sorry to find such a backwardness in the People," Shippen informed Bouquet, "to come with their

${ }^{335}$ Forbes to Pitt, July 10, 1758 in Stewart, Papers of Forbes, 26. Other examples of this reliance on the patriotism of citizens can be seen in Forbes to Pitt, May 1, 1758; Forbes to Peters, August 28, 1758 in Stewart, Papers of Forbes, 14 \& 31; Forbes to St. Clair, June 8, 1758, FP, GD 45/2/22-31; Fauquier to Byrd, November 12 , 1758; Fauquier to Assembly, November 12, 1758 in Reese, OPFF, 1:104-105.

${ }^{336}$ Forbes to Peters, August 28, 1758 in Stewart, Papers of Forbes, 31. Similar comments are made in Forbes to Pitt, July 10, 1758; Forbes to Allan, November 25, 1758 in Stewart, Papers of Forbes, 26 \& 68.

${ }^{337}$ Bouquet to Stephenson, June 3, 1758 in Stevens, Papers of Bouquet, 2:28.

${ }^{338}$ Bouquet to Forbes, June 7, 1758 in ibid, 2:50.

${ }^{339}$ Bouqeet to Shippen, June 3, 1758, 2:26, Shippen to Bouquet, June 9, 1758, 2:63; Forbes to Bouquet, June 10, 1758, 2:64 in ibid. 
waggons to carry Provisions only from Carlisle to Rays Town. ${ }^{\prime 340}$ While Forbes certainly concurred, he ultimately realized that accepting willing wagoners for partial trips benefitted him more than attempting to force service on the unwilling.

Further recognizing the democratic sentiments of rural Pennsylvanians, the general instituted a dual system of appraising the value of wagons and their teams. He informed Weiser, "I do impower you hereby to name and appoint Appraisers to Value the Waggons \& Horses in Behalf of the Crown, jointly with those appointed by the Magistrates in behalf of the Owners." ${ }^{341}$ Beyond appraising wagons, Weiser had also been entrusted with the appointment of wagonmasters to command the convoys needed to transport supplies. ${ }^{342}$ On June 1,1758 , however, farmers subjected to Weiser's judgment rejected his choice and selected their own representative. They petitioned Bouquet, stating:

We ... beg leave to recommend to your Honour, Jacob Weaver a Freeholder . . . as a fit person to be a Deputy Waggon Master, and whom we could wish to be employ'd to Superintend and have the Charge of our own Waggons, as from a long and thorough Acquaintance we know him to be an Active, careful, and honest Man ... we should not have given your Honour this Trouble . . . had it not happen'd that one George Redd a Man by no means fit for such an Employ, \& of a bad Character had imposed himself on Conrad Weiser Esqr. As a person fit to be recommended. ${ }^{343}$

Forbes caved immediately to these demands, when nine days later he shifted the organization of the wagonmasters. ${ }^{344}$ The people had thus successfully rejected a royal appointee and installed their own man. Finally, it had become apparent to the British officers by June that approximately 150 horses belonging to the Crown had found their way into the stables of Pennsylvanians after the destruction of

\footnotetext{
${ }^{340}$ Shippen to Bouquet, June 9, 1758 in ibid, 2:63.

${ }^{341}$ Bouquet to Weiser, June 5, 1758 in ibid, 2:33.

${ }^{342}$ Weiser to Bouquet, June 14, 1758 in ibid, 2:90.

${ }^{343}$ Petition of Wagoners, June 1, 1758 in ibid, 2:3-4.

${ }^{344}$ Forbes to Bouquet, June 10, 1758 in ibid, 2:65.
} 
Braddock's army in 1755 . Although the possessors of these horses undoubtedly considered them their own after three years, the British officers believed otherwise and badly needed the horses to assist in the convoys. Although Bouquet suggested that Forbes might recover the horses by "menacing those that disobey with the penalty of the law," he simultaneously advised "promising a crown for those that bring or find them" as an inducement for Pennsylvanians to return the military's property. ${ }^{345}$ This system of rewarding Pennsylvanians to comply with British law further demonstrates the failings of royal authority as a concept in democratically-inclined Pennsylvania.

Besides the civilian populace, the British officers found themselves unable to dominate the provincial forces under their command. In mid-June 1758, Major Stephen informed Bouquet that Captain Field's company of artificers demanded, and ultimately received, heartier rations including "Hominy \& bread made of Indian Meal." ${ }^{346}$ In the more serious manner of provincial discipline, Forbes and Bouquet found themselves unable to punish crimes. Desertion proved one of the particular problems confronting the military, but the British officers felt uncomfortable prosecuting provincial soldiers. ${ }^{347}$ When Forbes instructed Bouquet to discipline them as he saw fit, Bouquet confided to Forbes that "I do not think that they can be hung." ${ }^{348}$ Instead, Bouquet ordered Stephenson to put together a military court comprised of Pennsylvanians to see to the punishment of these soldiers. ${ }^{349}$ This judicial body inevitably treated its soldiers more leniently than the British military would have. Forbes consequently appears to have recognized the local realities and embraced the need to work within them. Unfortunately for the proprietary faction, those realities of individualism and democratic notions represented the very values they proposed to limit, thus making the general a less than ideal ally.

\footnotetext{
${ }^{345}$ Bouquet to Forbes, June 7, 1758 in ibid, 2:51.

${ }^{346}$ Stephen to Bouquet, June 7, 1758 in ibid, 2:53.

${ }^{347}$ Forbes to Bouquet, June 10, 1758 in ibid, 2:65.

${ }^{348}$ Bouquet to Forbes, June 7, 1758 in ibid, 2:50.

${ }^{349}$ Bouquet to Stephenson, June 3, 1758 in ibid, 2:28.
} 
Besides his apparent willingness to work within the existing political system, Forbes's philosophies regarding the ongoing debate proved problematic for the proprietary faction. Early upon his arrival in Pennsylvania, the general observed the "fresh Disputes which arise every day." ${ }^{350}$ The proprietary party likely discovered a disquieting fact about Forbes and his officers early on: they could not care less about provincial political squabbles beyond their immediate effect on Forbes's operations. The general unequivocally stated "I utterly detest all partys and views in military operations, so you may very well Guess, how and what arguments I have had. ${ }^{351}$ For Forbes and his officers, the overarching, singular goal remained victory on the battlefield. As such, the officers considered their role limited to capturing the French fortifications on the Ohio River. When discussing the future security of the post, Bouquet lectured Allan that "[w]e have acted our parts, let you do yours." 352 To achieve victory the British officers proved willing to utilize any institution-local or provincial, democratic or oligarchicthat assisted their ultimate goal. This willingness "to adjust all Matters to the Satisfaction of all Parties" undoubtedly disappointed any member of the proprietary interest who had hoped for support against their political foes. ${ }^{353}$

Finally, what proved most damaging to any remaining hope that the proprietary faction had for intervention in its favor was the untimely death of the victorious general Forbes in March of 1759, shortly after his successful completion of the task assigned to him by the British Ministry. Forbes's triumph represented just the type of victory that the general's London confidant, Ross, had suggested when alluding to the future patronage of Ligonier and Pitt. If Ross proved correct, Forbes stood to gain considerable support at home. Thus, any advantage that the proprietary part might have gained by

\footnotetext{
${ }^{350}$ Forbes to Pitt, May 1, 1758 in Stewart, Papers of Forbes, 13.

${ }^{351}$ Forbes to Bouquet, July 14, 1758 in Stevens Papers of Bouquet, 2:207.

${ }^{352}$ Bouquet to Allan, November 25, 1758 in Stewart, Letters of Forbes, 69.

${ }^{353}$ Fauquier to Forbes, November 19, 1758 in Reese, OPFF, 1:108.
} 
forging a relationship with the general either privately or through public efforts to advance his campaign in 1758 were dashed with his passing. 


\section{Chapter 4: Pennsylvanians and Indian Policy}

Similar to issues of political authority in Pennsylvania, various factions in the colony differed widely in their assessment of which entity possessed the authority to control diplomatic relationships with neighboring Native American peoples. Those associated with the proprietary faction emphasized their executive powers, tending to suggest that they consequently possessed a monopoly on such dealings. The Assembly rejected this notion, insisting that their commissioners, as the representatives of the people, deserved to play a role in diplomacy. After their self-imposed exodus from the Assembly in 1757, many Quakers attempted to exert their influence in Indian affairs as an avenue to continue to combat the proprietary. Outside Pennsylvania, the Superintendent of Indian Affairs for the Northern Department, Sir William Johnson, likewise involved himself in the province's Indian relations. Primarily operating through his principal deputy, George Croghan, the Superintendent competed with both factions while generally pursuing his own interests. Although the Superintendent's authority in Pennsylvania remained unclear due to the existence of a southern Superintendent, his interests largely coincided with those of the Iroquois Confederacy. Not willing to sit idly by as the landscape of Pennsylvania became radically transformed during the Seven Years' War, the Confederacy actively engaged in the defense of its traditional hegemony in the region to the chagrin of Pennsylvania's Delaware population. The Delaware actively sought to use the conflict to regain their autonomy from the Iroquois while also recover lands lost to Pennsylvania. As they had with other issues, Forbes and his officers attempted to rise above the fray by working with varying groups and interests in an attempt to bolster the chances of victory on the Ohio in 1758.

Conflict over Indian affairs pre-dated the Seven Years' War and the arrival of the British military in 1758. The Penn family relied upon land sales in Pennsylvania as a source of income, leading their agents in the province to pursue increasingly aggressive land cessions from neighboring native peoples. 
The infamous Walking Purchase represents perhaps the most audacious land acquisition. In 1737, Provincial Secretary James Logan prepared to act upon an agreement with local Lenape peoples that dated back to the 1680 s. According to the Secretary, the Lenape had agreed to cede to Pennsylvania a tract of land along the Lehigh River equivalent to the distance a man could walk in a day but other parties contended that Logan fraudulently augmented the size of the cession. He cleared a route through the woods and employed a team of runners to navigate the path. His efforts resulted in a claim of more than twice the amount of territory the Lenape had assumed would be ceded. Appeals to the Iroquois Confederacy, which claimed hegemony over both the region and the Lenape people, received little consideration as the Confederacy chose to maintain a friendly relationship with Pennsylvania at the expense of the Lenape. In fact, the Iroquois played a pivotal role in formulating the initial "agreement." The colony's Assembly, at this time still dominated by Quaker elements, sympathized with the neighboring natives and demanded access to proprietary documents relating to Indian affairs. Refusal on the part of proprietary agents to allow such access led the Assembly to accuse their counterparts of dishonestly producing such agreements with the natives.

The conflict over land acquisition had not diminished by the time of the Seven Years' War, and the impasse assumed a heightened importance as violence between natives and the colony's inhabitants increased and politicized the issue for a broader Pennsylvanian audience. The arrival of Forbes also focused attention on the issue because the success of his military mission rested partially on the pacification of the region's native population. The Quakers subsequently argued that the surest path to winning back the province's formerly friendly neighbors would be to satisfy their concerns about the fraudulent land dealings of the proprietary faction. Such satisfaction might only be given if they received access to the pertinent documents, but members of the proprietary faction possessed incentives to keep those documents private. 
On March 14, 1758, new Provincial Secretary Richard Peters informed longstanding provincial interpreter Conrad Weiser that the two men had been selected by the proprietors to act as their principle agents in ongoing negotiations with the Delaware peoples over the land disputes so long the source of controversy in Pennsylvania. As far as the proprietary faction believed, the appointees represented the true and only valid diplomatic entities in the colony. ${ }^{354}$ Such a premise rested on the proprietary assumption that it possessed exclusive executive power within the province. In response to Quaker demands for access to the Council's bookkeeping, for example, Peters defended this right, noting:

[T]hese Books contain the most important Affairs of government many of which require the greatest secrecy, [the governor] cannot allow the perusal of them to any but those concerned in the administration. And further that He looks upon the transacting of Business with the Indians in this province to be a matter so intirely pertaining to himself that He cannot permit any but such as are immediately, by the King's Authority, or by his own to treat with or intermeddle in the Affairs of that People. ${ }^{355}$

Peters's reference to the "King's Authority" proves critical to the nature of the dispute between the proprietary and popular faction. As they had on other matters of authority, the proprietary faction rested its case on the hierarchical functions of the state. In the case of native diplomacy, they hoped to demonstrate that the Indians, as "foreign Princes and an Independent People," could only be treated with by the King's agents. ${ }^{356}$ Denny definitively penned such sentiments, and informed the Quakers that:

${ }^{354}$ Peters to Weiser, March 14, 1758 in Conrad Weiser Papers (hereafter CWP), Vol. 1, Fol. 9, 700, HSP.

${ }^{355}$ Peters to Callander \& Pemberton, January 25, 1757 in Friendly Association Minutes, 1755-1757 (hereafter FAM), AM.525, HSP.

${ }^{356}$ Denny to Quakers, July 15,1757 in ibid. 
The Proprietaries have acquainted me that the Earl of Halifax has communicated to them with very strong Expressions of dissatisfaction, a Treaty held with the Indians at Philadelphia with the People called Quakers, which his Lordship was pleas'd to think was the most Extraordinary, proceedure he had ever seen in Persons, who are on the same footing only of all others of the King's private subjects to presume to Treat with foreign Princes. And further that as the suffering any one part of the King's subjects, whether of a different Profession of Religion, or however else distinguish'd to Treat or act as Mediators, between a Province in which they Live, and any Independent People, is the highest Invasion of His Majesty's Prerogative Royal and of the worst consequence as it must tend to divide the Kings subjects into different parties and Interest's and by how much more these or any other body of People are suffer'd to attach the Indians to their own particular Interest, by so much less must their Regard to People of other Professions be. The Proprietaries have therefore directed me, not to suffer those People or any other Body or particular society in Pennsylvania to concern themselves in any Treaty with the Indians, or on any pretence to suffer, presents from such Persons, to be given to the Indians, or to be join'd with the Publick present at any such Treaty. These Directions I shall conform to, and my Regard for you as well as Mr. Penn's Instructions lead me to observe, it would be prudent in you to decline going in a Body [to negotiations]. your attendance at Treaties as a distinct society having given great offence to the Ministry. ${ }^{357}$

The faction framed interactions with natives as the prerogative of the proprietary, as a consequence of its connection to the Monarchy. They cast any behavior conflicting with this authority as inappropriate if not bordering on treasonous.

\footnotetext{
${ }^{357}$ Denny to Quakers, July 11, 1757 in ibid.
} 
Beyond this theoretical basis for executive control of diplomacy, which conformed to other clashes proprietary agents had with elements of the popular faction, members of the proprietary faction possessed personal motivations for excluding their opponents from the diplomatic process. Friends of the Penn family stood to gain vast properties and wealth if the natives could be convinced to allow the acquisitions. Many of their enemies suggested this as they attempted to identify fraudulent land dealings. Peters, perhaps the most virulently opposed to Quaker interference in Indian affairs, held vast lands in Tulpchocken and along the Schuykill. Conrad Weiser, the official interpreter for the colony, likewise possessed economic incentives for excluding the Assembly and its friends from infringing on provincial diplomacy. ${ }^{358}$ The German immigrant faithfully served Pennsylvania's governors for decades, and so had earned the favor of the Penn family, sometimes at the expense of his less fortunate fellow citizens. In 1755, for example, he lamented to Peters about his inability to "get the lands the proprietors gave" him because Irish squatters currently resided on the land in question. ${ }^{359}$ The extent of the avarice of Peters and Weiser remains unclear, but they maintained a degree of secrecy that suggests economic motives in their attempt to monopolize Indian diplomacy. "I have much to say to you," Peters once wrote Weiser, "that cannot be committed to paper." ${ }^{360}$ The men's enemies in the Assembly, however, appear to have understood their complicity, and struck back as they could. Weiser lamented these attacks to Peters, noting:

I have served the government of pensilvania as provincial Interpreter since the year 1731 to the satisfaction of the governors and assembly's as much as I know, I never heard nothing to the Contrary, till 3 years ago when a Certain set of gentlemen got the administration or the purse into their hand, then I Could no more please, haveing ben a

${ }^{358}$ Benjamin Lightfoot to Peters, October 31, 1758 in CWP, Vol. 1, Fol. 9, 700, HSP; Weiser to Bouquet, June 14, 1758 in Stevens, Papers of Bouquet, 2:90.

${ }^{359}$ Weiser to Peters, July 22, 1755 in CWP, Vol. 1, Fol. 9, 700, HSP.

${ }^{360}$ Peters to Weiser, March 14, 1758 in ibid. 
little to free, when the Blood of the back Inhabits. Was spilt like watter, and they in a manner unconcerned, they did let me suffer prodigiously and showed their spite openly to me, for what reason well known to them, to you, and to me, but I wont give up the point, truth will prevail at last. ${ }^{361}$

Referring here to the refusal of the Assembly to reimburse him for funds expended in the service of the colony, Weiser identified an attempt by proprietary enemies to use their power of the purse to attack his activities and, as they deemed it, profiteering as proprietary agent.

The ability of the Assembly to attack the finances of Weiser must have served as a potent reminder to the proprietary faction that despite its theoretical claims to exclusive control of diplomacy, it did not operate in a power vacuum. The power of the popular faction, resting upon its connection to the people, meant that it would be a player in diplomatic affairs regardless of the "constitutional" authorities of the executive branch. The extent to which the executive tolerated the presence and participation of other elements in its negotiations with native peoples can only be explained in this context.

Throughout the 1750s, and despite hostility towards outside involvement in diplomacy, agents who represented the proprietary interests routinely allowed Quakers and representatives of the Assembly to be involved in the process. Despite his severe rhetoric about the role of his government in diplomatic affairs, Denny allowed outsiders an audience, going so far as to issue passes to various Quakers in the event that they were denied admission in his absence. Beyond allowing access to negotiations, the agents failed to dominate the discourse with their native audience. Accounts of Pennsylvania's negotiations with the Lenape recount numerous scenes of conflict between Peters, who frequently took charge of the executive's argument, and commissioners dispatched by the Assembly

${ }^{361}$ Weiser to Peters, December 16, 1758 in ibid. 
about how to frame the province's official statements at such meetings. ${ }^{362}$ The heated negotiations between the two factions demonstrates that though they represented two sources of authority in the colony, they did not possess the ability to overpower the other. Perhaps it comes as no surprise, then, that the proprietary faction took to placating the popular faction in an apparent attempt to shore up its purported authority at conferences with the natives.

Despite the intermittent hostility, the proprietary faction thanked the popular faction's agents for assistance rendered at negotiations. Denny went as far as to acknowledge the positive nature of the Quakers' intentions. ${ }^{363}$ These public comments represented mere flattery, but the proprietary faction hoped that they might smooth relations enough to allow them to conduct their affairs without interference. Towards that end, the executive appeared to budge ever so slightly on the prickly issue of deeds and bookkeeping. On November 30, 1756, Denny informed Israel Pemberton, leader of the most active Quaker opposition group, that he would receive all accounts of land treaties in the possession of the government. ${ }^{364}$ While Pemberton continued to wait into January of 1757 , the proprietary faction informed him that they would only be able to release documents that "could not affect the current administration." ${ }^{365}$ Finally deciding not to release the documents at all, Peters suggested to the Quakers that a reprinting of Samuel Hopkin's Historical Memoirs, relating to the Housatunnick Indians might be helpful. Pemberton felt otherwise and continued to agitate for the deeds throughout 1758.

Denny, perhaps finally realizing his inability to stop the Quakers from participating in the diplomatic process completely, tolerated their inclusion in conferences. On one occasion, the governor issued Quaker presents alongside those of the province. He read the items aloud to the Indians to make clear which came from each entity. Denny stood firm only on his restriction on giving wampum,

\footnotetext{
${ }^{362}$ Denny to Pemberton, November 3, 1756; Denny to Pemberton, November 12, 1758 in FAM.

${ }^{363}$ Denny to Pemberton, November 16, 1756; Denny to Quakers, July 14, 1757 in ibid.

${ }^{364}$ Denny to Pemberton, November 20, 1756 in ibid.

${ }^{365}$ Peters to Callender \& Pemberton, January 25, 1757 in ibid.
} 
retaining that right exclusively for the government. ${ }^{366}$ The governor's commitment to maintaining his sole authority to dispense wampum speaks to the shallowness of the proprietary party's commitment to include the popular faction in diplomatic affairs. They may have made minor concessions to placate their rivals, but wampum's symbolic connection to negotiation for native peoples of the region remained too powerful to be shared. The popular faction, of course, saw right through these "concessions." 367

The rivals, both desiring preeminence in native diplomacy but too weak to dominate its counterpart, consequently engaged in a spirited public relations campaign to win support for their cause. The factions reflected their ideological conception of the source of power and authority and appealed to different audiences. Ultimately uninterested in winning the approbation of Pennsylvania's citizenship, the proprietary faction looked to London. Denny consequently sent the minutes of conferences to one John Hunt in London "to be made such use of, as himself and other judicious Friends in London may agree shall be necessary." ${ }^{368}$ The minutes apparently achieved their intended effects, as the Quakers concluded correctly that the proprietary faction had fostered a hostile view of their activities with London observers. Most notably, they blamed Halifax's severe rebuke to such "misrepresentations." 369

The popular faction, on the other hand, intended to combat proprietary actions within Pennsylvania. They doggedly attempted to put proprietary agents on the public record about the deals because they deeply suspected the veracity of past land treaties. With access to the deeds still being pursued, they hoped to deal their competitors a crippling blow when they one day might prove the depths of fraud invading the executive elements in the province's government. "Surely if he [Peters]

${ }^{366}$ Denny to Pemberton, November 3, 1758; Denny to Pemberton, November 16, 1756; Peters to Callender \& Pemberton, June 7, 1757 in ibid.

${ }^{367}$ Norris to Franklin, April 7, 1757 in INL, 1154, HSP.

${ }^{368}$ Denny to Quakers, November 1, 1757 in FAM, Am.525, HSP.

${ }^{369}$ Denny to Quakers, July 11,1757 in ibid. 
were assured that Justice had always been done to the Indians," the Assembly's commissioners announced sardonically at one conference, "this must be a fair opportunity of obtaining a public Testimony of it and the suspicions in the minds of many be effectually removed?"370 The strength of the popular party's argument, therefore, rested in what they claimed to be fact as opposed to their opponents' use of misrepresentation. "What we have said concerning the Proprietaries and their Agents," they informed Denny, "is grounded on the Publick Records." ${ }^{371}$ Denny's secretiveness appeared to confirm these suspicions for the popular faction. Upon receiving a request for permission to print the events of one treaty, Denny declined because the Quaker account "contains some Reflections on the Conduct of the Proprietaries, and their Agents here in managing the affairs of the Indians, which I hope will be found to be without the least foundation." ${ }^{372}$ Denny's refusal to grant the request suggests the possibility that the popular faction engaged in a bit of misrepresentation as well. Just as the Quakers accused the proprietary faction for misrepresenting them in London, the proprietary faction claimed a similar activity directed towards the province's population. According to Peters, the Quakers intended to use the minutes of conferences with natives, if allowed access to such meetings, to “blacken the Proprietors and support a Party." ${ }^{173}$ The secretary went on to suggest that the Quakers planted the seeds of unrest in the minds of the Lenape themselves in an attempt to damage the position of the proprietors in the colony. ${ }^{374}$

It remains unclear to what extent these public relations efforts succeeded. Military officers in the pay of the province continued to interact closely with local native peoples throughout the 1758 campaign. ${ }^{375}$ Rather than adopt the popular faction's view that Indian relations might be engaged by

${ }^{370}$ Denny to Pemberton, November 12, 1756 in ibid.

${ }^{371}$ Denny to Quakers, July 15, 1757 in ibid.

${ }^{372}$ Ibid.

${ }^{373}$ Denny to Pemberton, November 15, 1756 in ibid.

${ }^{374}$ Ibid.

${ }^{375}$ Examples of such interactions occur in Levi Trump to Forbes, January 21, 1759; Patterson to Forbes, January 21, 1759 in FP, GD 45/2/97, SNA; Letter from the Commissioners, ND in FP, GD 45/2/53-67, SNA; Burd 
various elements of society, the officers approximated more closely the proprietary faction's assumption that diplomacy must be strictly controlled by proper elements. Colonel Burd reflected this assessment while corresponding with a subordinate officer. He informed the officer that "[n]o Person here is to be permitted to Deall with Indians (Excepting the governments' agents for Indian affairs) \& the agents are to be supported to the utmost of your power." ${ }^{376}$ While the officers might be expected to reflect the proprietary faction's views as a consequence of their commissions that deprived from the governor, other entities shared this view as well. In 1756, for example, the Society for the Propagation of the Gospel identified its own solutions to the growing hostility of native peoples towards Pennsylvania. Led by Dr. William Smith, an Anglican reverend, the society suggested that the public good might best be served by restricting interaction with native peoples to appropriate government entities. According to the proposal, no private persons should possess the right to deal with native communities without permission from government authorities. Although Richard Peters did work with Smith to develop the society, its proposals along with the actions of the officers suggests that significant elements of society respected executive authority over Indian affairs. They consequently rejected the Quaker public relation campaign against this exclusion. ${ }^{377}$

Opponents to such a monopoly continued to be active, but their solidarity began to fracture. The Assembly assumed leadership in contending diplomatic authority based on its electoral connection to the populace. The Speaker of the House, Isaac Norris, indicated that the Assembly and people had traditionally ignored land dealings with natives because they previously acknowledged the proprietary power to control such endeavors. The violence unleashed by neighboring Indians against Pennsylvanian

to Denny, April 13, 1758, Burd to Denny, April 26, 1758, Burd to Denny, May 3, 1758; Burd to William Allen in SFP, Vol. H, Col. James Burd Letterbook, 595A, HSP.

${ }^{376}$ Burd to Trump, May 23, 1758 in SFP, Vol. H, Col. James Burd Letterbook, 595A, HSP.

${ }^{377}$ Frank J Klingberg, "The Anglican Minority in Colonial Pennsylvania, with Particular Reference to the Indian,” The Pennsylvania Magazine of History and Biography, Vol. 65, No. 3 (July 1941): 291, 293 \& 296. 
settlers after Braddock's 1755 defeat, however, radically altered the status quo in Noriss's opinion. ${ }^{378}$ "As Proprietary Purchases are now found to Concern every free holder who Enjoys his lands under them;" he wrote Franklin, "the last assembly appointed a Commitee. To make a search for them, thro ye Council minutes but were refused." ${ }^{379}$ Norris and the Assembly concluded that the principal source of native hostility derived from previous acquisitions of land, and because that hostility affected everyone, the matter consequently had fallen into the purview of the popularly-elected Assembly. Access to the documentation of the dealings to determine their legitimacy would allow the Assembly to act properly on the matter. ${ }^{380}$ The continued refusal by the governor and Council to provide access infuriated the Assembly and bred hostility. "[W] hether by design, or meer blundering, our Indian affairs are surprisingly conducted," Norris noted, "\& it seems almost treason for any others to Interfere." ${ }^{381}$ This hostility resulted in rash behavior by the legislative body, which elicited continued intransigence from the governor and his supporters. The Pennsylvanian "Assembly have advised him [Denny] in pretty warm terms to invite some of the Chiefs of these Indians to their City, in order to confirm them in their friendship which he very Justly declined," Commander-in-Chief of British forces in North America James Abercromby related to Superintendent Johnson, "he was for closing with the advice of his Assembly; but upon representing to him the bad Consequences that might result from so hasty a step he waved his Opinion." ${ }^{382}$ Denny's initial willingness to act upon the Assembly's recommendations might have fostered a more cooperative approach to Indian diplomacy in Pennsylvania, but Abercromby's opposition to the Assembly's "warm terms" encouraged the governor to pursue a more hard-line approach to working with his counterparts.

\footnotetext{
${ }^{378}$ Norris to Franklin, October 17, 1757 in INL, 1154, HSP.

${ }^{379}$ Ibid.

${ }^{380}$ Norris to Partridge, November 24, 1757; Norris to Pownall, January 19, 1758 in ibid.

${ }^{381}$ Norris to Charles, December 4, 1757 in ibid.

${ }^{382}$ Abercromby to Johnson, April 4, 1758 in Edward H. Knoblauch ed., The Papers of Sir William Johnson
} (hereafter PWJ), Digital Ed. (Albany, New York, 2008). 
In addition to the Assembly, elements of Pennsylvania's Quaker community attempted to influence the direction of the province's diplomacy with native peoples. The Quakers created the Friendly Association for Regaining and Preserving Peace with the Indians by Pacific Measures in 1756 to pursue these goals and many redirected their energies to the organization after withdrawing from the Assembly. ${ }^{383}$ Israel Pemberton, a passionate opponent of the proprietary government, emerged as the Association's most prominent and active member. The Quakers recognized that withdrawing from the legislature stripped them of any legitimate political power. Thus, the organization attempted first to coordinate its efforts with Denny's predecessor as governor, Robert Hunter Morris. Initially, the Association found Morris receptive to their assistance. "The governor expressed his approbation of our Design and gave us full liberty to prosecute our Intentions," the organization's official minutes recorded in April of 1756, "if he would advise and direct the manner of proceeding, nothing more was desired by us than under his direction to proceed therein in such manner as would be most agreeable to him, most effectually answer the purpose intended and demonstrate that we did not act from views of private advantage." ${ }^{384}$ When questioned by Johnson about the propriety of their actions, Pemberton quickly fell back on this initial approbation. He informed the Superintendent that "[t]hose Conferences have been held by the Permission of our governor." ${ }^{385}$ Pemberton and his fellow members poured themselves into their activities, immediately raising $£ 1200$ at a time when the actual government of the colony experienced difficulty raising funds of any type. ${ }^{386}$

Despite these efforts, the partnership between Morris and the Friendly Association fell apart rather quickly. "[W]e were informed that the governor had given orders that no Person should speak with the Indians," Pemberton reported from a conference at Easton. "[T]he governor," he continued,

${ }^{383}$ Wellenreuther, "Quest for Harmony," 569.

384 "Minutes of the Proceedings of the People called Quakers in Philadelphia towards regaining and preserving Peace with the Indians by pacific Measures," FAM, AM.525, HSP.

385 Pemberton to Johnson, May 25, 1756 in ibid.

386 "Morris Message to Susq. Indians," in ibid. 
"said . . . that he should treat them as his Majesty's Enemies if they held any Conference with the Indians on any matter relating to the government, and that he had strictly charged the same to be observed by all Persons whatsoever." ${ }^{\prime 38}$ The Quakers refused to accept such a change of heart. The Association argued that no such prescription had been laid against the Moravians, and so continued to pursue official sanction for their actions. They quickly contacted Denny when he replaced Morris and formed a committee tasked with representing the Association to the governor, Council, and Assembly. ${ }^{388}$ The proprietors themselves intervened in the affair, allowing the Friendly Association to operate as long as it remained within proper boundaries. They wrote to the organization, approving their efforts "in regaining \& reestablishing a good understanding with the Indians, without desiring to encroach on the powers of the Crown, delegated to the generals, now employed amongst you, or to us as Proprietarys." 389

While the Quakers strove to operate "with the approbation or Consent of ye. Government under which we live," they had no intention of halting their behavior should that consent be withdrawn, because they insisted that they occupied the moral high ground. ${ }^{390}$ According to their view, the unprecedented violence that erupted between Pennsylvania's natives and colonists resulted from the fraudulent land dealings conducted by the proprietary government. The only complaints against the actual people of Pennsylvania, they argued, resulted from encroachments by hunters and abuses by traders, which proved a minor nuisance to natives when compared to the massive amounts of land lost to the proprietary government. As a consequence, they claimed, the proprietors remained responsible for rectifying the impasse. ${ }^{391}$ Their Friendly Association minutes stated:

${ }^{387}$ Ibid.

${ }^{388}$ Quakers to Denny, November 3, 1756; Articles and Rules, December 23, 1756 in ibid.

389 Thomas Penn and Richard Penn to The Trustees \& Treasurer of the Friendly association for regaining \& preserving Peace with the Indians by pacific measures, September 6, 1760 in Cox-Parrish-Wharton Papers, 154, Series 4, Box 14, Folder 15, HSP.

${ }^{390}$ Articles and Rules, December 1, 1756 in ibid.

${ }^{391}$ Denny to Pemberton, November 3, 1758 in ibid. 
The calamity became general and every one became deeply interested in the measures taken for enquiring into the causes which induced our ancient steady Friends to become our Enemies: yet this being the proper Business of those then concerned in the administration of the government we waited the Event of their Proceedings, having just grounds to hope that the Knowledge some of them had of several matters which might probably have contributed to this unhappy rupture, together with the repeated Applications of the assembly of the Province, would have excited them to pursue every rational Method of making such an Enquiry and obtaining an amicable adjustment of all Differences with these Indians. ${ }^{392}$

Towards that end, members of the Association petitioned the governor to be attentive to the Indians' land concerns. They also aggressively attempted to acquire the documentation of land dealings so they could "help," but the response proved disheartening. ${ }^{393}$ "The difficulties Friends have encounter'd with to bring our ungodly Rulers to do so much as has been done towards an amicable adjusting Differences wth ye Indians," Pemberton lamented, "is scarce credible." ${ }^{394}$ The proprietary government's failure to address the root causes of the conflict appeared, in the eyes of the Quakers, to be a dereliction of duty. Pemberton referred to "my bleeding Country whose Interest is not sufficiently considered and promoted by some who are bound by both sacred and civil obligations." ${ }^{395}$ The Friendly Association deeply resented the "many malicious Calumnies and aspersions ... cast upon us by Persons from whom we had a right to expect encouragement and assistance" in attempting to bring peace between Pennsylvania and its neighboring native peoples. ${ }^{396}$ The Quakers ignored such aspersions, casting

\footnotetext{
${ }^{392}$ Minutes of the Proceedings of the People called Quakers in Philadelphia towards regaining and preserving Peace with the Indians by pacific Measures in ibid.

${ }^{393}$ Henton Brown to James Pemberton, October 4, 1758 in Pemberton Family Papers (hereafter PFB), 484A, HSP; The memorial of the Freemen To William Denny, July 12, 1758 in FP, GD, 45/2/53-67, SNA.

${ }^{394}$ Israel Pemberton to Samuel Wily, December 2, 1758 in PFB, 484A, HSP.

${ }^{395}$ Pemberton to Hardy, May 26, 1756 in FAM, AM.525, HSP.

${ }^{396}$ Morris Message to Susq. Indians, June 6, 1756 in ibid.
} 
themselves as the only party possessing the requisite "concern for the Publick welfare" in the absence of proper leadership from the government. ${ }^{397}$

Leaders in the proprietary party, however, rejected Quakers claims to the moral high ground and insisted that personal motivations influenced the actions of the Friendly Association. Pemberton in particular engaged himself actively in the Indian trade. He possessed trading posts for that purpose. When peace with local native peoples became a reality after the final meeting in Easton in the fall of 1758, the enterprising merchant expanded his operations. In December of that year, he requested and received permission from Maryland's governor to open trade in that colony. At the same time, he enlisted fellow Quaker James Kenny to travel to the newly conquered post at the Forks of the Ohio on his behalf. Kenny, who established himself in the growing town of Pittsburgh in the coming years, became one of the first Indian traders to arrive in the newly secured region. ${ }^{398}$ As the Friendly Association's most active and visible member, Pemberton's activity appeared to many as self-serving and it cast doubt upon the moral stance taken against what they claimed were misguided or absent diplomatic efforts by the proprietary government. Pemberton's involvement in diplomatic affairs might thus appear to be designed to ensure his status with the natives for personal profit.

Other members of the Association recognized the incongruity, and condemned the industrious member's activity. "We are fully satisfy'd in our Judgements," they informed him, "that to prosecute thy said Intentions of settling a store at Fort Cumberland at this time in the manner thou propos'd is very Exceptionable \& will be productive of Bad Consequences." ${ }^{399}$ Pemberton resented such a rebuke and responded that "I have had a prospect of serving the publick without any Considerable prejudice to

${ }^{397}$ Minutes of the Proceedings of the People called Quakers in Philadelphia towards regaining and preserving Peace with the Indians by pacific Measures in ibid.

${ }^{398}$ Ezra Croasdale to Israel Pemberton, February 12, 1759; I. Ridout to Israel Pemberton, December 20, 1758 in PFP, 484A, HSP; James Kenny Journal, 1758-1763, 339, HSP.

${ }^{399}$ Friendly Association to Israel Pemberton, December 25, 1758 in PFB, 484A, HSP. 
my own Interest." ${ }^{\prime 400}$ From his perspective, and perhaps conveniently fortunate for his business, trade with the natives had become essential to the public welfare, because the conflict disrupted native access to European goods. "[H]e thought delays might be dangerous to ye. Publick Intrest," Kenny recorded, "in not sending goods in due time to ye. westward." ${ }^{401}$ Several years later, when General Jeffrey Amherst assumed command of British forces in North America, he enacted a series of disastrous policies that severely restricted trade with native peoples throughout the colonies. Contemporary and modern observers have concluded that the restrictions contributed significantly to Pontiac's Uprising, and thus may validate Pemberton's defense of his actions. ${ }^{402}$

The refusal of the Quakers to acknowledge the proper authority of the proprietary government to treat with natives, regardless of the outcomes, proved most damaging to any attempts to coordinate the two party's efforts. Throughout the final and successful peace treaty at Easton in the fall of 1758, agents of the Friendly Association, led by Pemberton, interfered continuously with the proprietary government's efforts. The journal of Benjamin Chew, member of the Council, records a series of events that nearly resulted in violence.

On October 11, Chew and three associates discovered that the Quakers had convened a meeting with Delaware leaders in a church against the strict prohibition against such interaction ordered by Governor Denny. The men casually approached the church hoping to get an idea about the nature of the meeting. One of the men entered the building observing twenty or thirty members of the Friendly Association and Pennsylvania Assembly, but the conversation became hushed when his presence became known. Later that day, Chew recorded a nearly violent exchange between James Logan and Israel Pemberton. "Mr. Logan came over to us \& sd. He had been very ill used by I. Pemberton in the

\footnotetext{
${ }^{400}$ Israel Pemberton to Friendly Association, January 15, 1759 in ibid.

401 James Kenny Journal, 1758-1763, 339, HSP.

${ }^{402}$ For a discussion of the causes of Pontiac's Uprising, see Dixon, Never Come to Peace Again.
} 
publick street," the journal reports, "Logan clenchd. His Fist \& told him he had often abused him, but to take care of himself for he wou'd bear it no longer, \& said that the affinity that was between them was the only reason why he did not knock him down, wch. He wou'd certaily do if he took the like Liberties with him for ye future." ${ }^{403}$ The Quaker leader justified his abuse, claiming that "Mr. Logan had shamefully obstructed the Publick Peace for 2 years past $\&$ he $c d . \&$ wd. Prove it, he shou'd by $\&$ by be at Liberty to speak soon and it shou'd all come out." ${ }^{\prime 404}$

Nine days later, a second incident concerning the proprietary government's attempt to control the dispensing of liquor nearly resulted in violence. "A confounded Fracas happened this morning about a Centries being placed by the governor on some of Vernons Liquors," Chew wrote, resulting in an attempt to make "the streets resound with the Epithats Liberty \& Privilege." ${ }^{405}$ This language, "Liberty \& Privilege," clearly identifies the motivations and justifications of the Quaker organization. These concepts, as opposed to the hierarchical notions of authority embraced by the proprietary faction, stood at the root of all the political issues between the groups. Now out of power, the Quakers continued to embrace these sentiments with regards to Native American diplomacy. The proprietary government, they believed, had neglected its duty to defend the public interest by attempting to fairly treat with the Indians. In lieu of that leadership, they claimed the right to involve themselves to solve the impasse.

These sentiments encouraged the Quakers to take their most precipitous step at the Easton meetings. Governor Denny had tolerated the Association's presence at the conference and had allowed the separate dispensing of gifts from the organization, but he had definitively declared that no wampum could be distributed. As the symbolic medium of negotiation for most native peoples in the region, wampum represented legitimacy for them. Denny intended to monopolize this commodity to ensure

\footnotetext{
${ }^{403}$ Benjamin Chew Journal, AM.043, HSP.

${ }^{404}$ Ibid.

${ }^{405}$ Ibid.
} 
his government's preeminence at Easton. In preparation for the meeting, however, Pemberton had attempted to acquire his own wampum to lend weight to his organization's efforts. ${ }^{406}$

The final confrontation recorded by Chew demonstrates clearly the proprietary government's ideological view on the actions of the Friendly Association. On the afternoon after the liquor riot erupted, Pemberton could no longer contain himself while attending the government's conference with the Indians. "He riggled and twisted about in his seat," Chew wrote, "and mutterd something that I coud not hear. At last he broke out \& said it was a vile Fraud $\&$ an Imposition on the Indians, \& we as Freemen will not sit patiently by and be witnesses of it." ${ }^{407}$ In response, Chew "told him he was a madman ... [and] asked him what right he had to interpose at all in the case, or what he meant by Fraud \& Deception in the Deed of 1745." 408 “I told him he was crazy," Chew continued, "\& an Enemy to the Peace of his country." ${ }^{\prime 409}$ The angered Councilman left Pemberton with a dire warning, informing his brother that "if he took the same Liberties wth. Me he had done wth. Others I shoud not keep my hands off him. ${ }^{410}$ Chew's questioning of Pemberton's right to even attend the conference proves significant, as the proprietary government assumed that their tolerance of the Friendly Association's presence represented a courtesy. As they had claimed in other political debates, authority and prerogative needed to be respected by the "Freemen" of Pennsylvania. In the case of diplomacy, the executive branch of the government represented by the governor possessed exclusive right to conduct negotiations as it saw fit. Ultimately, Chew reflected the views of his compatriots by dismissing the Quakers as a set of "busy mischievous ffellows." ${ }^{411}$

Quaker persistence at the treaty likewise resulted from the Friends' longstanding connection and commitment to their native neighbors, which dated back to William Penn's founding of the colony.

\footnotetext{
${ }^{406}$ George Bowne to Israel Pemberton, April 29, 1758 in PFP, 484A, HSP.

407 Benjamin Chew Journal, AM.043, HSP.

408 Ibid.

409 Ibid.

${ }^{410}$ Ibid.

411 Ibid.
} 
In this sense, the moral high ground claimed by the Friendly Association extended beyond the public interest to include fair dealings with whom they referred to even in private correspondence as the "[i]njured natives." ${ }^{412}$ Pemberton insisted to correspondents in London that the Friends must involve themselves because "[t]here are others ready [to do so], who it's to be fear'd, will administer what they call Help in such manner, as will be lastingly hurtful." ${ }^{413}$ Consequently, the Quakers considered themselves indispensible to any meetings with the natives. ${ }^{414}$ At such encounters, they believed that the natives would more readily speak with them because "we did not speak with our mouths only but from our hearts." ${ }^{415}$

The Quaker commitment to treating the Indians fairly, however, created additional issues because the natives meeting with Pennsylvanians represented interest groups of their own. Numerous Indians bordered the province and had interacted with it following its founding, but none had been more intertwined with the colony's development than the Lenape, or Delaware, peoples. Initially located in the eastern portions of what became Pennsylvania, the Delaware had been displaced to the westward following a series of land dealings with the proprietary government. None of these had proven as significant as the infamous Walking Purchase of 1737. By the time of the Easton conference in 1758, these peoples had realigned themselves into two loosely connected populations, one residing along the upper Susquehanna River valley and the other removing themselves into the upper Ohio River valley. While the western element of the Delaware threw their lot in with the French following Braddock's defeat in 1755, the eastern band attempted to remain neutral in the conflict. The choice proved a precarious one, as the eastern Delaware subsequently found themselves under pressure from their western brethren to join the fight while simultaneously facing hostility from their Pennsylvanian

${ }^{412}$ Mary Pemberton to Mary Weston, June 16, 1758 in PFB, 484A, HSP.

${ }^{413}$ Israel Pemberton to Samuel fothergill, Thomas Gawthrop, Abram Farrington, \& Mordecai Yarnell, April 6, 1758 in Pemberton Family, Pemberton-Fothergill Correspondence, 484A, Vo. 34, HSP.

${ }^{414}$ Elias Bland to Israel Pemberton, July 12, 1758 in PFB, 484A, HSP.

415 James Pemberton to John Pemberton, October 10, 1758 in ibid. 
neighbors, who either could not tell the difference between the two groups or simply refused to trust any Indian while at war with other native peoples. In an attempt to protect his people, an eastern leader named Teedyuscung began reaching out to Pennsylvania with proposals to broker a peace between the province and his western cousins.

Teedyuscung travelled to Bethlehem in June 1756 to meet with Governor Morris. In July 1758, he likewise attempted to meet with Governor Denny. Exchanges with the governors, however, left the Delaware leader upset and dissatisfied with the responses. Principally, Teedyuscung sought restitution for fraudulent land dealings, most significantly the Walking Purchase, as part of any peace negotiations. According to James Pemberton, who attended the Easton meeting with his brother Israel, the Delaware leader at one point stood up in conference asking Denny if the King had made a determination on the differences the natives and Pennsylvania had over land issues. In addition, Denny admitted in private correspondence that conversations with Teedyuscung had indicated that Delaware attacks had principally resulted from long-simmering displeasure with the Walking Purchase. Publically, however, the governor and his allies refused to acknowledge native claims and insisted that all land dealings had been fair, equitable, and agreed upon by both sides. ${ }^{416}$ In an apparent attempt to defend their position, the proprietary faction, the Quakers charged, had embarked upon "schemes laid to depose old Ted."417

The schemes referred to might have been the proprietary claims that the Quakers had implanted the idea of restoring lost lands in the mind of Teedyuscung, thus perhaps attempting to diminish the legitimacy of his demands. According to Chew, on several occasions the Delaware leader had privately conceded the land issue when not with the Quakers. He had, moreover, been convinced to claim otherwise by "incendiaries." Chew presumed that Pemberton represented the source of these

${ }^{416}$ James Pemberton to Hannah Pemberton, October 18 in ibid; Denny to Forbes, July 4, 1758 in FP, GD 45/2/53-67; Benjamin Chew Journal, AM.043, HSP; Denny to Pemberton, November 3, 1756; Morris Message to Susq. Indians, June 6, 1756 in FAM, AM525, HSP.

417 James Pemberton to Hannah Pemberton, October 18, 1758 in PFP, 484A, HSP. 
notions. ${ }^{418}$ While the veracity of Chew's claims about Teedyuscung's private sentiments remains unclear, it seems quite unlikely that the Quakers managed to convince the Delaware that the Walking Purchase had been fraudulent. Few contemporaries (outside of the proprietary faction) or modern observers could seriously dispute the dishonesty inherent in the particulars of the deal. Teedyuscung and his people thus had ample cause for resentment against the Pennsylvanian government. The leader almost certainly proposed restitution on his own accord, although the Quakers likely encouraged his sentiments. Their promises of support might have emboldened Teedyuscung to make the demands in the first place.

The proprietary faction's assumption that the Quakers caused the Delaware to arrive at their conclusions probably resulted from appearances of intimacy and trust between the two peoples. In 1756, Governor Morris reported a conversation with two Delaware named Newcastle and Pumpshear, who informed him that they considered the Quakers, not the proprietary government, as truly interested in peace because they were "the Descendents of those who first came over to this Country with your old Friend William Penn."419 The Delaware further informed Morris that they would "not say anything to the governor, unless the Quakers were present. ${ }^{\prime 420}$ Later that year, Teedyuscung informed Governor Denny that the Quakers should be allowed to send a wampum belt along with that of the government as peace negotiations began. Additionally, he declared that the Quakers had his explicit permission to look into their complaints over land fraud.

At the Easton conference in 1758, Chew recorded this intimacy by noting that Teedyuscung and Pemberton routinely sat together while in conference. ${ }^{421}$ The relationship between the Delaware and Quakers rested in part on a mutual affinity for one another. Newcastle and Pumpshear's reference to

\footnotetext{
${ }^{418}$ Benjamin Chew Journal, AM.043, HSP.

${ }^{419}$ Morris Message to Susq. Indians, June 6, 1756 in FAM, AM.525, HSP.

420 Ibid.

${ }^{421}$ Denny to Pemberton, November 3, 1756 in ibid; Benjamin Chew Journal, AM.043, HSP.
} 
William Penn and the Quaker tradition in Pennsylvania certainly hearkens back to a better time when the province legitimately treated its native neighbors with a measure of respect and fairness so often absent in European dealings with indigenous peoples. The entire issue of the Walking Purchase and land fraud was exacerbated by the fact that something had fundamentally changed in the proprietorship and its views on Indians. Mutually beneficial political outcomes, however, encouraged close coordination between the Delaware and Quakers that went beyond their very real friendship.

The symbolic connection Newcastle and Pumpshear made between the Quakers and Pennsylvania's founder could not have been lost on both factions in the province. The Quakers had traditionally dominated the colony's assembly and had only recently, and willingly, relinquished its control over the legislature. They remained a potent political force should they wish to return to the Assembly and to become an even greater nuisance to the proprietary government. Teedyuscung's insistence that both the government and Quakers deliver wampum belts would have further reminded the proprietary faction that they did not, despite their claims, possess sole ability to treat with native peoples. While the governor and his allies continued to cling to British notions of hierarchy, the Delaware leader's invitation demonstrated that the natives did not consider themselves bound by Pennsylvania's political structure or British conceptions of authority. The invitation thus served to strengthen the Quaker case for shared diplomatic authority. Finally, Teedyuscung's request that the Quakers look into his complaints likewise bolstered their requests for access to proprietary bookkeeping. Consequently, the close relationship between the two peoples ensured that the Quakers would remain relevant even while out of office. It comes as no surprise, then, that the Quakers vigorously defended Teedyuscung and the Delaware against proprietary attempts to marginalize him, calling him a "man of consequence." 422

${ }^{422}$ Benjamin Chew Journal, AM.043, HSP. 
The Delaware benefitted directly from propping up Quaker power in Pennsylvania because the proprietary government had forged its own alliance with native peoples to the great detriment of the Delaware. Pennsylvania had mirrored New York in forming a "covenant chain" with the powerful Iroquois Confederacy, which claimed most of the lands the province hoped to acquire by right of conquest. The Confederacy thus felt free to sell lands actually inhabited by the Delaware, and found Pennsylvania a more than willing customer. The Iroquois, in fact, had played a pivotal role in bringing about and defending the Walking Purchase. This relationship lay at the root of much of the reason the proprietary government ignored Delaware claims leading up to and at Easton: the Confederacy simply proved a much more pliable entity from which to acquire lands. The Iroquois claimed ownership of the lands in question, and further insisted that they had earned the right to control Delaware diplomacy. Therefore, Pennsylvanian government felt secure in pursuing its aims. Consequently, Teedyuscung and his people considered alliance with the Quakers as the only avenue to break this cabal and restore their former position.

The Iroquois, equally interested in ensuring their position by backing the proprietary government, thus became an additional element in the diplomatic struggle in Pennsylvania. The proprietary government's dealings with the Confederacy derived from British imperial policy that recognized its hegemony over the regions being questioned by the Delaware. The Iroquois confirmed those sentiments, berating Teedyuscung at Easton for assuming diplomatic powers that did not belong to him as a consequence of their previous conquest of the region. ${ }^{423}$ As a result, the province sought to engage "the Indians of the six nations to promote the Restoration of Peace" as early as $1756 .{ }^{424}$ In an

${ }^{423}$ Ibid; State of the actual Possessions of the Crown of Great Britain in No. America at the Treaty of Utrectht in PRNA, MSS 33029, BL.

${ }^{424}$ Morris to Indians William Newcastle, Locquies, Jiggreu, April 26, 1756 in FAM, AM.525, HSP. 
attempt to protect their interests in the region, the Iroquois complied, sending representatives to various meetings between Pennsylvania and the Delaware. ${ }^{425}$

The invitation of Pennsylvania and acceptance by the Six Nations reflected similar motives to the Delaware-Quaker alliance. The proprietary government, of course, wanted the Iroquois present to continue to legitimize their hegemony, thus validating earlier land deals and ensuring future acquisitions. Johnson acknowledged the critical role that the Iroquois played in forging the eventual agreements at Easton. "Without the zealous Mediation of the Six Nations at this Treaty in our favour," he informed Abercromby, "things would not have taken the happy turn they have done." ${ }^{426}$ The Confederacy sought to comply with these aims, but the situation for them had become more dire by 1758. Beginning in the 1720 s, disparate native groups had drifted into the upper Ohio River valley that had been depopulated, likely as a result of earlier Iroquois raids. These groups included the aforementioned western Delaware, but Shawnee people augmented their numbers. Together, these refugees sought to carve out new homes, communities, and identities. Most important for many, they sought to protect themselves not only from the abuses of Europeans, but also from Iroquois dominance. The Six Nations attempted to curb this independence by commissioning "Half Kings" to oversee the migrants in what they considered their territory. The new communities loosely observed this oversight, but many scholars consider their participation in the Seven Years' War on the side of the French as not just a rejection of the British but Iroquois dominance as well. ${ }^{427}$

As the Ohio Indians fought to overthrow the hegemony of the Six Nations, the eastern Delaware continued to observe it reluctantly-until Teedyuscung began to question the land deals forged by the Pennsylvanians and Iroquois. Rejection of the deals, by default, equated to rejection of the

425 Journal of Indian Affairs, July 301758 in Knoblauch, Papers of Sir William Johnson.

426 Johnson to Abercromby, November 10, 1758 in ibid.

${ }^{427}$ For a discussion of the settlement of the upper Ohio River Valley, see Michael McConnell, A Country Between: The Upper Ohio Valley and Its Peoples, 1724-1774 ( Lincoln, NE: University of Nebraska Press, 1992). 
Confederacy's authority to make them. Hugh Mercer, commanding in Pittsburgh through the critical winter of 1758-1759 after the expulsion of the French, reported the anxiety the Iroquois felt about their position and the reliance they had on the British and Pennsylvanians in maintaining their status. According to the major, Six Nations representatives informed him privately that they feared the departure of the British would leave them to face the Ohio Indians alone. If the British did not stay and assist the Confederacy, they said, "we will both be killed."

As a consequence of this anxiety, the Iroquois engaged Pennsylvanians in subterfuge to keep the Delaware and their friends in check. At Easton, representatives met privately with both the Delaware and Pennsylvanians. ${ }^{429}$ Mercer's experience with other Iroquois diplomats at Pittsburgh in January 1759 illuminates the methods by which the Six Nations hoped to maintain its exalted status. The Ohio Indians had been convinced to abandon the French in favor of peace with the British and Pennsylvania, but this agreement had been predicated on their forces removing themselves from the territory upon the expulsion of the French. Without their native allies, the French abandoned Fort Duquesne in November 1758 about a month after the conference at Easton ended and as the forces of Forbes slowly approached. Possessing no intention of relinquishing the Forks of the Ohio after such a laborious and costly campaign, Forbes left Mercer with a small force to occupy the former site of Fort Duquesne and begin the construction of a temporary fortification to secure their victory. The sight of ongoing construction of a fortification did not sit well with the Ohio Indians, who had come to associate fortifications with permanency. The presence of Mercer, therefore, threatened the embryonic peace that had so recently been agreed upon.

As Mercer confronted the demands of the Ohio Indians, who expected the Brithish to fulfill their promises and vacate the Ohio Country, the Iroquois came to his rescue and devised a solution that

\footnotetext{
${ }^{428}$ Mercer to Denny, January 6, 1759 in FP, GD 45/2/97, SNA.

${ }^{429}$ Benjamin Chew Journal, AM.043, HSP.
} 
mutually benefited the Confederacy and its British allies. A delegation approached Mercer privately and informed him that they intended to speak in front of the Delaware and Shawnee the next day, but cautioned him that "you are not to mind what is said there, it is outside my lips, but what is now said be attentive to, for it comes from my Heart." "Tomorrow I will give you that Belt to return home to your own Country," they continued, "but you are to return it back to me and tell me at the same time that you are resolved to stay here and fight the French till they are drove off from this County." ${ }^{230}$ By advising Mercer to reference the French forces still occupying smaller posts to the north of the Forks, the Iroquois had devised the pretense for continued British presence in the region and thus provided them with the additional strength they required to continue to dominate the peoples they claimed as subordinates. At the same time, however, their public demand that Mercer evacuate served to ingratiate them with the very people they hoped to control, thus encouraging a semblance of solidarity which would be useful to the Six Nations' ambitions.

The Iroquois and Pennsylvania brokered another deal at Easton intended to placate the eastern Delaware and Quaker claims of fraudulent land dealings. The proprietary government agreed to give back land west of the Susquehanna River purchased from the Iroquois in 1754 on the pretense that actual payment had never been made for the territory. In exchange, the Iroquois had to agree that they would later sell the land to nobody but Pennsylvania. ${ }^{431}$ The deal accomplished two goals. First, it transferred at least some land from Pennsylvania back into native hands, and thus made the proprietary government appear more reasonable and attentive to native concerns. The Quakers and Delaware could no longer claim that they remained intractable and unwilling to listen to native demands. At the same time, the deal reaffirmed Iroquois hegemony in the region and left the door open for future purchases. It remains unclear to what degree the Ohio Indians or eastern Delaware were fooled by

${ }^{430}$ Minutes of Conferences held at Pittsburgh with the Indians, January 3, 1759 in FP, GD 45/2/97, SNA.

${ }^{431}$ A Deed, October 14, 1758; Journal of Indian Affairs, November 18-December 4 in Knoblauch, Johnson Papers. 
these ruses, but the Quakers saw right through it. The Quakers became highly agitated at Easton because the Iroquois dominated the conversation and, not surprisingly, accepted the proprietary land deals. One Quaker noted explicitly that "measures were used wth. The 6 nation Indians to compel the Delawares to contradict what they had before said." ${ }^{432}$ Others continued to insist upon the right of the Delaware to control their own lands.

The positions of all the parties vying for diplomatic advantage in Pennsylvania became more complicated due to the interest of Sir William Johnson. As Superintendent of Indian Affairs for the Northern Department, Johnson possessed broad powers for negotiating with native peoples from Pennsylvania to the northwards. Johnson had come to the colonies as an Irish immigrant and established himself on an uncle's estate on the Mohawk River in New York. Taking to his Iroquois neighbors, the young Irishman became a trusted and respected adoptive member of the Mohawk people. His influence with the Iroquois became so renowned that Braddock carried a commission with him to America in 1755 making Johnson Britain's Superintendent of Indian Affairs, an office intended to provide a consistency with native diplomacy so often lacking among the independent and competing colonial governments. In 1758, Edmund Atkin returned to South Carolina carrying a commission from the Board of Trade making him the Superintendent of Indian Affairs in the Southern Department, leaving Johnson in charge of the north.

At first glance, Johnson appeared a natural ally for the proprietary government of Pennsylvania. The Superintendent maintained favor for the interests of the Six Nations, as did the proprietors. His commission likewise represented the legitimate hierarchal authority so important to the faction. As a consequence, the governor and his allies routinely recognized that authority. In 1756, Governor Morris instructed neighboring natives that "you are to take notice, that nothing proposed by me is to interfere with any Invitation you may have received from Sir William Johnson . . . for we are both in the service of

\footnotetext{
${ }^{432}$ Benjamin Chew Journal, AM.043, HSP.
} 
one King and act his Directions." ${ }^{433}$ At Easton in 1758, moreover, Chew defended the presence of Johnson's principal lieutenant, George Croghan, against Pemberton's attacks by insisting "that he [Croghan] had at least as much right to be here as Is Pemberton had, for he attended the Treaty by order of Sr. W Johnson." ${ }^{434}$ The Superintendent additionally served the proprietary government's interest because he tended to raise the ire of the popular faction, which tended not to accept the concepts of hierarchy as readily. In response to Chew's comments, for example, Pemberton retorted that "Sr William himself had no authority or right to be here, nor any thing to do with it, \& if he was here he [Pemberton] would tell him so." ${ }^{435}$ Isaac Norris, speaker of the Assembly, likewise questioned the establishment of a superintendent. "[Y]e method proposd by apointg superintendents for ye Districts to ye northward \& southwd is better in theory than Practice," he informed Franklin, "till they can find sutible men, undr. ye prest managet. we can only judge by ye fruit, of wch I know of none worth recomg." 436

In reality, Johnson did not feel compelled to support colonial governments against internal political competition. "[Y]ou will so conduct your Proceedings," he informed one of his agents before dispatching him to Pennsylvania, "as to have an Eye only to the Good of His Majestys Service in general \& avoid entering into the Views of any particular Person or Party." ${ }^{437}$ His salary and operational finances, moreover, came from the military, ensuring that any loyalty he might feel would be to the commanders who controlled dispensing the funds. ${ }^{438}$ In addition, the Irishman considered colonial governors the greatest threat to his own authority as they had traditionally managed each province's diplomacy individually. "General Johnson thinks these Proceedings contrary to the commission given him by General Braddock by which he was appointed sole Superintendent of the Indian Affairs [and]

\footnotetext{
${ }^{433}$ Morris Message to Susq. Indians in FAM, AM.525, HSP.

434 Benjamin Chew Journal, AM.043, HSP.

435 Ibid.

${ }^{436}$ Norris to Franklin, June 13, 1758 in INL, 1154, HSP.

${ }^{437}$ Instructions for George Croghan, July 21, 1758 in Knoblauch, Johnson Papers.

${ }^{438}$ Johnson to Abercromby, March 24, 1758 in ibid.
} 
That He cannot fulfill the Kings Expectations, if his Proceedings are to be controlled by a Governor," Governor Shirley of Massachusetts reported. ${ }^{439}$ Johnson's refusal to attend the Easton conference proved even more troubling for any hopes of the proprietary faction for assistance from his quarter. ${ }^{440}$

To protect the Northern Department's interests at Easton, Johnson dispatched fellow Irish immigrant George Croghan to attend "with proper Instructions, \& directions to assist, \& cooperate with Govr. Denny in bringing about, and settleing a Peace with the Ohio \& Western Indians." ${ }^{441}$ Similar to Johnson, Croghan had migrated to the colonies, in this case Pennsylvania, and established himself as a successful Indian trader. He had, however, developed a reputation for avarice and self-interest and his intentions and loyalties at Easton thus proved even more difficult for the various parties to identify than those of Johnson would have been. Croghan appears to have drifted in and out of the various camps at Easton, never explicitly or publically throwing his lot in with any one of them. ${ }^{442}$ In later years the Indian agent proposed fixing a boundary between natives and colonists to maintain peace, a proposal likely aimed at maintaining his brisk trade with natives unchallenged by neighboring colonists. ${ }^{443}$ This interest in his personal fortune would also have likely fostered competition with Quakers such as Pemberton, who likewise hoped to engage in trade. It might also have led him to favor elements of Pennsylvania's government as discussion about licensing traders percolated at the time. Finally, the Irishman almost certainly favored the Iroquois over the Delaware because his current status relied upon the continued goodwill of Johnson.

The opaqueness of Croghan's activities at Easton led to a level of distrust among the Pennsylvanian factions. Chew reported that the Quakers complain'd that “Croghan was in their councils

${ }^{439}$ Dispatches between Governor Shirley \& General Johnson in PRNA, MSS 33029, BL.

${ }^{440}$ Johnson to Abercromby, September 10, 1758 in Knoblauch, Johnson Papers.

441 Johnson to Abercromby, April 13, 1758 in ibid.

442 Benjamin Chew Journal, AM.043, HSP.

443 For a discussion of boundary proposals see Cameron B Strang, "The Mason-Dixon and Proclamation Lines: Land Surveying and Native Americans in Pennsylvania's Borderlands". The Pennsylvania Magazine of History and Biography. Vol. CXXXVI, No. 1 (January, 2012): 9. 
\& at the bottom of it. Sd. He was a Rascal ... that they cod. Prove he had sd. To Vernon that we shod. Have no Peace, that he was not an Englishman but an Indian, \& they thot. this matter shou'd be enquir'd into by the Govr." Chew advised caution, responding that "we had nothing to do with Croghan nor he wth. us, that what they proposd. Was a Ticklish measure, $\&$ that if he was a bad man all we had to do was to watch him \& be on our guard agst. him. and that if we publickly accused him and he had so great an Influence over the 6 nation Indians as they sd. He had it might be attended wth. mischievous consequences." ${ }^{444}$ Norris, heading the Assembly, ultimately began to check into Croghan's background by acquiring reports he had made while working in the Ohio River Valley. ${ }^{445}$ This mistrust by the popular faction resulted in outright hostility and opposition, which led Pemberton to declare that Croghan "was a Rascal and Vilain \& it was a shame he should have the management of the Indians." ${ }^{\prime 46}$

Various comments made by Quakers leaves little doubt about what they believed "the influence Croghan was then under" referenced. ${ }^{447}$ At Easton, the Quakers accused him of attempting "to raise a diference among the Indians \& give the 6 nations an ascendency over ye Delawares that did not belong to them." 448 James Pemberton likewise referred to "a scheme of Croghan" to his wife, further indicating that the various natives at the conference complained about his actions. ${ }^{449}$ Finally, a report compiled by the Quakers reviewing the transactions of 1758 lamented "[t]he iniquity of Croghan in obtaining a Release of the susquehanah Lands to the six Nations without any regard to ye Delawares \& after repeated promises to hear their Case." ${ }^{450}$ The proprietary faction continued to disavow any involvement with Croghan, one of its members telling Pemberton "with a good deal of warmth ... that we had

${ }^{444}$ Benjamin Chew Journal, AM.043, HSP.

${ }^{445}$ Norris to Pownall, March 22, 1759 in INL, 454, HSP.

${ }^{446}$ Benjamin Chew Journal, Am.043, HSP. 484A, HSP.

${ }^{447}$ Facts to be pointed out: "Deception of the Proprietery Party respecting Indian Deeds \&c. 1758" in PFP,

${ }^{448}$ Benjamin Chew Journal, Am.043, HSP.

${ }^{449}$ James Pemberton to Hannah Pemberton, October 17, 1758 in PFP, 484A, HSP.

${ }^{450}$ Facts to be pointed out: "Deception of the Proprietary Party respecting Indian Deeds \&c. 1758" in ibid. 
nothing to do wth Croghan or know what he was about." ${ }^{451}$ At the same time, however, and perhaps because they, too, had concluded that the agent intended to bolster Iroquois claims, the faction cautiously defended him even while denying any complicity with his actions. In response to Pemberton's outburst against the Irishman, Chew responded by noting that "tho they [Quakers] were pleased to charge him [Croghan] with playing Tricks with the Indians \& retarding the Business, it was base suspicion $\&$ they did not pretend they had any proof of it." ${ }^{\prime 452}$

While the arrival of Croghan exacerbated the already volatile diplomatic situation at Easton, General Forbes and his army plodded slowly along towards Fort Duquesne. The General hoped desperately that a deal would be brokered to improve his chances at successfully completing the expedition. In 1757, then-commander of British North American forces Lord Loudoun berated Governor Denny for attempting to control Indian diplomacy, stating:

The King has seen that his Indian Interest has been lost in a great Measure by the Management of the different Provinces in whose Hands it was originally placed; therefore has appointed two Persons with large salaries for the management of all his Indian Affairs: one for the Northernn Indians \& the other for the southern; with orders to the Commander in Chief to supply them with Money to inspect into their Conduct \& give proper Directions to them ... Notwithstanding the Kings Instructions in the management of his Indian Affairs; \& the Letters writ on that subject last summer, both by sir Wm. Johnson \& by me to you, the People of your Province have obstinately insisted on carrying on Negotiations with the Indians \& have even sent to negotiate with them separately in the Kings Agents own House ... I cannot help thinking that . . . they

\footnotetext{
${ }^{451}$ Benjamin Chew Journal, AM.043, HSP.

${ }^{452}$ Ibid.
} 
will see its their Interest as well as their Duty to pay obedience to the Kings Commands

\& not to interfere with the Prerogative of making Peace \& Warr. ${ }^{453}$

Loudoun identified correctly the new state of colonial diplomacy after the establishment of the Superintendents, but he had also been sent home by 1758 to fight for his career and reputation after failing to achieve victory in North America.

Equally cognizant of the new protocol, Forbes attempted to operate through the Superintendents as well. Recognizing Johnson's attention would be focused on the Iroquois and New York where Abercromby currently conducted a simultaneous campaign, the general spent the summer and fall seeking the assistance of Croghan writing to various correspondents he thought capable of prevailing on the agent to join him on his expedition. ${ }^{454}$ "[A]ssure him that his presence with me would be a reall satisfaction to me," he wrote Denny, "as he is both acquainted with the Country and Inhabitants, so that the sooner he comes (since left at his own disposal) I shall look upon it as a mark of favour towards me." ${ }^{455}$ Although Croghan chose to remain in Easton and only joined Forbes at the very end of his campaign, the general generally approved of his actions. ${ }^{456}$ At the same time, however, the absence of the Superintendent and his agent left Forbes feeling somewhat abandoned. Early in the campaign, the general wrote Johnson, wishing that "he [Croghan] may arrive in Time to be of any Service, for all those affairs have some how been cruelly neglected, and are at Present in the Greatest Confusion. ${ }^{\prime 457}$ The continued absence of either of the agents led Forbes to write a scathing letter to Pitt. "I did imagine that I shou'd have had the Assistance of Sir William Johnston, and of Mr. Atkins in the Manadgment of those Indians, Being informed that those Gentlemen are soley to superintend Indian

${ }^{453}$ Loudoun to Denny, May 5, 1757 in Cox-Parrish-Wharton Papers, 154, Series 4, Box 14, Folder 15, HSP.

${ }^{454}$ Abercromby to Johnson, August 20, 1758 in Knoblauch, Johnson Papers; Forbes to Peters, August 28, 1758 in Stewart, Letters of Forbes, 31; Forbes to Denny, September, FP, GD 45/2/68-81, SNA.

${ }^{455}$ Forbes to Denny, September in FP, GD 45/2/68-81, SNA.

${ }^{456}$ Forbes to Peters, October 16, 1758 in Stewart, Letters of Forbes, 57.

${ }^{457}$ Forbes to Johnson, May 4, 1758 in Knoblauch, Johnson Papers. 
Affairs, exclusive of any other Person," he wrote the minister, "[b]ut as Sr. William continued at his settlement 500 Miles North of this . . I f found myself obliged either to act as I have or must have seen those Indians return to their own Country disgusted." ${ }^{458}$ He further ensured that the negligence of the Superintendents did not escape the notice of the men's mutual superior by informing Pitt that "the Indians ... having had no manner of Assistance from either off the Superintendents of Indian Affairs." ${ }^{459}$ Forbes proved more flexible than Loudoun had, however, and he became willing to identify alternate sources of assistance in managing Indian relations. Recognizing the former position of governors in the colonies, the general relied heavily on Governor Denny and elements of the proprietary government. "As this meeting promises to be pretty General \& as you appear to me the leading person in so beneficial an alliance," Forbes wrote Denny concerning the Easton meeting, "I should therefore think that you will leave no stone unturned." ${ }^{\prime 60}$ The proprietary faction took pleasure in the reliance the general seemingly placed on them in the absence of Johnson's attention. "[A]ssure yourself that the general has not wanted good advice," Peters informed Weiser, "\& I believe he has followed it." ${ }^{461}$ The provincial secretary further reveled in Forbes's misfortune with the Superintendents, explaining to Weiser that "[i]n this most uncomfortable situation he has recourse to you \& me." ${ }^{\text {662 }}$ At first glance, the general appeared pleased and satisfied with the assistance rendered by the proprietary government. "It gives me very great pleasure that the Negotiations begun and transacted under your directions wears at present so favourable a Countenance," he wrote Denny, "I hope for your honour and the publick good that at next meeting you will be able to settle every thing with the Indians." ${ }^{463}$

Members of the popular faction, however, painted a very different picture of the relationship between Forbes and their competitors. According to Speaker Norris, "Genl. Forbes ... had some warm

\footnotetext{
${ }^{458}$ Forbes to Pitt, May 18, 1758 in Stewart, Letters of Forbes, 19.

${ }^{459}$ Forbes to Pitt, June 17, 1758 in ibid.

${ }^{460}$ Forbes to Denny, September, FP, GD 45/2/68-81, SNA.

${ }^{461}$ Peters to Weiser, December 22, 1758 in CWP, 700, HSP.

${ }^{462}$ Peters to Weiser, July 28,1758 in ibid.

${ }^{463}$ Forbes to Denny, September, FP, GD 45/2/68-81, SNA.
} 
Difference upon these messages [to Indians], wth ye council." ${ }^{464}$ Pemberton personally began to correspond with Forbes during the campaign, and in contrast to the actions of the proprietary government, the Friendly Association reported the general's approval of their conduct. ${ }^{465}$ "[T]he Course of our Conduct in this service to manifest that the promoting the Interest of our King \& Country was the Real object of our Desire We have from time to time acquainted the King's generals, who have been here with our Proceedings \& have received from several of them satisfactory Testemonials of their approbation," the organization informed the proprietors, "and we apprehend it may be justly said that under Divine Providence The Ingenuous \& Prudent Resolution of general Forbes in pursuing those Pacific measures contributed principally to the withdrawing the ohio Indians from the French Interest." ${ }^{466}$ Christian Frederick Post, a member of Pennsylvania's German population that had typically supported the Quaker's political stance, likewise received high praise from the general for his service during the campaign. Post had been charged with the unenviable task of travelling deep into French-controlled territory to meet with Indians in the upper Ohio River Valley in order to apprise them of the conferences planned at Easton. In recognition of his harrowing voyage, in which he was nearly captured by the French, Forbes reserved his highest commendations. "I think he has execute the Commission he was sent upon, wth ability and Fidelity," Forbes wrote Peters, "and deserves a proper reward."467

Forbes's apparent inconsistency in praising both factions, while simultaneously criticizing them privately if Norris is to be believed, reflects the practices he had developed on the other major issues he had confronted in supporting his expedition. The general proved remarkably flexible in the sources from whom he sought support, and he likewise proved unwilling to place his reliance on such an important

${ }^{464}$ Norris to Franklin, June 13, 1758 in INL, 1154, HSP.

${ }^{465}$ Pemberton to Forbes, July 4, 1758 in FP, GD 45/2/97, SNA.

${ }^{466}$ The Address of the Trustees \& Treasurers of the Friendly association for regaining \& preserving peace with the Indians by pacific measures to Thomas Penn and Richard Penn Esquires Proprietaries \& governors in Chief of the Province of Pennsylvania, March 20, 1760 in Cox-Parrish-Wharton Papers, 154, Series 4, Box 14, Folder 15, HSP.

${ }^{467}$ Forbes to Peters, October 16, 1758 in Stewart, Letters of Forbes, 57. 
occasion on any one entity. His correspondence also demonstrates his continued recognition, and distaste, for the effects that factionalism had had on the progress of his efforts. Referring to Croghan, Forbes hoped that "he will be convinced that it is not selfish provincial or proprietary views that Influence the well wishers of this treaty, but a noble zeal for the support of His majestys measures in the defence of these Colonies and the saving of the lives of the Inhabitants." ${ }^{468}$

The general took a more authoritative tone with members of the proprietary faction. To Denny, he suggested that "Indians ... demands seriously considered can never be put in balance with the trouble and annoyance that they give those Colonies now that they are drove into the arms of the French During the War-I hope therefore that all triffles, private jealousys, and pieques, will now be laid aside and that a speedy and happy conclusion will soon be the Issue." 469 To Peters, Forbes lectured, "I am this moment flattering myself that from the joint endeavours of all with you, the dropping of foolish trifles, some measures will be taken with those originale Inhabitants as to strengthen ourselves ... giving up sometimes a little in the beginning will procure you a great deal in the end." ${ }^{\prime 40}$ The general's language towards Denny and Peters, and his failure to rebuke the Quakers or Assembly seriously, seems to suggest that he had perhaps recognized the proprietary faction's motives at Easton, which jeopardized the greater good. Norris confirmed this assessment privately to Franklin, noting that success might be achieved "if they are not preventd by our ... Politicks." ${ }^{\text {"71 }}$ Regardless of Forbes's possible preference for the popular faction's diplomatic methods and motives, the proprietary government still possessed more legitimate authority to conduct negotiations and thus remained capable of hampering the popular faction's efforts.

\footnotetext{
${ }^{468}$ Forbes to Denny, August 26, 1758 in Knoblauch, Johnson Papers; FP, GD 45/2/68-81, SNA.

${ }^{469}$ Forbes to Denny, September, FP, GD 45/2/68-81, SNA.

${ }^{470}$ Forbes to Peters, October 16, 1758 in Stewart, Letters of Forbes, 57.

${ }^{471}$ Norris to Franklin, July 25, 1758 in Norris Family Papers, 454, HSP.
} 
As a consequence of this reality and the ongoing factionalism in Pennsylvania, the overworked general assumed much more of the responsibility for dealing with natives than he would have hoped. Norris noted his participation, informing Franklin that "Genl fforbes has Interested himself in Indian Affairs." ${ }^{472}$ This "interest" manifested itself in several ways. He managed Indian spies, provided funds for the service, acquired and dispensed trade goods, regulated Pennsylvanian citizens' access to Indians to ensure that poor treatment would not undermine the peace efforts, provided consistent directives to Denny and Peters, and met with the leaders of various native peoples. ${ }^{473}$ Unfortunately for the beleaguered general, his Indian problems extended well beyond those neighboring Pennsylvania because the governors of Virginia and South Carolina had overseen the recruitment of substantial numbers of southern Indians to assist the campaign. Forbes found these natives a mixed blessing, as their arrival in the spring of 1758 required additional oversight, introduced new factional competitions and threatened to undermine the fragile peace being negotiated at Easton.

\section{${ }^{472}$ Ibid.}

${ }^{473}$ Peters to Weiser, July 28, 1758 in Conrad Weiser Papers, 700, HSP; Forbes to Pitt, May 18, 1758, Bouquet to Allen, November 25, 1758, Forbes to Peters, August 28, 1758, Forbes to Denny, May 3, 1758, Forbes to Denny, November 26, 1758; Forbes to Kings Beaver and Shingas, November 19, 1758 in Stewart, Letters of Forbes 17, 19, 31, \& 68; Major Halkett: Extract of Orders For Genl- Forbes in FP, GD 45/2/33-36, SNA. 


\section{Chapter 5: Southern Native Americans and Pennsylvania}

While the British and Pennsylvanians worked to reach a peace agreement with neighboring native peoples, they gathered indigenous allies of their own. The influence of prominent individuals in Virginia and South Carolina had convinced warriors from the south, most significantly the Cherokee, to join Forbes's campaign in large numbers by the spring of 1758 . The general and his officers came to consider these allies a mixed blessing, as they came to question native dependability throughout the course of the year. Many variables led to this assessment, but the failure to assign clear responsibility for handling diplomacy with the Cherokee played a significant role, as it had in Pennsylvania with its native neighbors. Here again, British officers too often found themselves the only entity reliable enough to maintain negotiations with the southern Indians. The British military ultimately diminished its reliance on the southern warriors, which led to a set of conditions that negatively affected the stability of relations between the southern colonies and the Cherokee.

The Cherokee had long acted friendly towards the British. Upon its founding in 1670, South Carolinians, perhaps paranoid about external Native American and internal slave threats, actively sought Indian alliances. The Cherokee proved a likely candidate. Located deep within the southern Appalachian Mountains, they found themselves increasing in influence around the turn of the century. Insulated from direct contact with Europeans and the diseases they surreptitiously carried, the Cherokee began to supplant stronger coastal Indians in size. As early as 1715, Cherokee and South Carolinian forces had warred together against other southeastern tribes. In 1730, furthermore, several Cherokee headmen made the dangerous passage to and from England to forge a formal alliance. Such actions, however, belied the true nature of Cherokee-Anglo relations. The Cherokee never existed as one united people with one united political objective. Rather, many different village, clan and regional identities comprised the so-called Cherokee nation. Consequently, Cherokee peoples developed a variety of relationships with Europeans. French influence, maintained through posts in the North American 
inteior, remained a present alternative to alliance with Britain. The Forbes' campaign therefore represented an opportunity to solidify an already strong relationship while simultaneously weakening or destroying French influence in Cherokee country. The complexity of the Cherokee socio-political structure, however, made it much more difficult for the British and their colonial counterparts to organize an effectively functioning mode of diplomacy during the Forbes Campaign. ${ }^{474}$

When viable military action became a reality in 1758 , the recruitment of Cherokee allies had already been extensively pursued by the southern colonies. As early as 1755, when General Edward Braddock launched his ill-fated attack on Fort Duquesne, the son of Christopher Gist had embarked on an unsuccessful mission to Cherokee country. ${ }^{475}$ The following year, Major Andrew Lewis of Virginia successfully managed to entice Cherokee warriors on his abortive Sandy Creek Expedition raids on Shawnee villages. ${ }^{476}$ Rather than participate in British campaigns, however, Cherokee warriors were more frequently recruited to range and raid independently. As Great Lakes and Ohio Country Indians descended upon the Virginia backcountry following the defeat of Braddock, officials relied on allies to deflect some of the violence. In the spring of 1756, Virginia dispatched Peter Randolph and William Byrd to recruit the Cherokee. ${ }^{477}$ By the fall, their efforts appear to have succeeded, as the colony reported supporting 350 warriors. ${ }^{478}$ Through the spring of 1758 , reports began to trickle into the capital at Williamsburg of Cherokee successes in the backcountry. ${ }^{479}$ That spring, Colonel Jeffrey Amherst informed General James Abercromby from South Carolina that perhaps seven hundred Cherokee had

${ }^{474}$ For a deeper discussion of Cherokee culture and development see Tyler Boulware, Deconstructing the Cherokee Nation: Town, Region, and Nation among Eighteenth-Century Cherokees (Gainesville, FL: The University Press of Florida, 2011); Tom Hatley, The Dividing Paths: Cherokees and South Carolinians through the Revolutionary War Era (New York: Oxford University Press, 1995), chapters 1-3; Daniel K. Richter, Facing East From Indian Country: A Native History of Early America (Cambridge, MA: Harvard University Press, 2001), 169.

${ }^{475}$ A Selection of George Croghan's Letters and Journals Relating to Tours into the Western CountryNovember 16, 1750-November, 1765 in Reuben Gold Twaites, ed., Early Western Journals: 1748-1765 (Lewisburg, PA: Wennawoods Publishing, 1998), 97-98.

${ }^{476}$ Ward, Breaking the Backcountry, 106.

${ }^{477}$ Pennsylvania Gazette, May 20, 1756. See also Ward, Breaking the Backcountry, 105.

${ }^{478}$ Pennsylvania Gazette, October 7, 1756.

${ }^{479}$ Ibid, April 14, 1757. 
already left to fight the enemy and that the Cherokee towns had emptied of warriors. ${ }^{480}$ Although Amherst's claims may be grossly overestimated, it remains apparent that many Cherokee had already taken to the woods in defense of British North America. It remained to be seen, however, how they managed when working closely with a European-style army accompanied by thousands of colonists.

With no written accounts of their own, the Cherokee leave behind no exact records pertaining to their service with the British in 1758. From the reports of the British, however, an image of a cooperative ally emerges. "The Cherokee and Catauba Indians," Forbes informed Pitt in an early assessment, "have been fully as good as their Promise." ${ }^{481}$ From the outset, Forbes and Bouquet recognized the necessity of Indian scouts. Provincials, with a few notable exceptions, simply would not do. Throughout the spring and summer of 1758 , Cherokees thus performed a critical role. Despite their commendable record of producing scalps, prisoners and information, the two European officers failed to ever trust fully their native allies. Consequently, Forbes decided to "gett some brisk officers from among the provincials to try some scouting partys with a good many Indians along with them." ${ }^{482}$ Bouquet agreed, noting "[w]e cannot deviate from this without being their [the Cherokees'] dupe." ${ }^{\text {"43 }}$ While the motivation may have been ill-founded, the results proved beneficial. Throughout the expedition, Cherokees and colonists came to know one another intimately and frequently reported positive interactions. $^{484}$

Anchoring Forbes's southern flank from Fort Cumberland, Colonel George Washington had already built a prominent reputation as a military officer by 1758 . He had, moreover, spent the better

\footnotetext{
${ }^{480}$ Amherst to Abercrombie, May 201758 in Edith Mays, ed., Amherst Papers: 1756-1763, The Southern Sector: Dispatches from South Carolina, Virginia and His Majesty's Superintendent of Indian Affairs (Westminster, MD: Heritage Books, 1999), 63.

${ }^{481}$ Forbes to Pitt, May 1, 1758 in Stewart, Letters of Forbes, 14.

482 James, Writings, 116.

${ }^{483}$ Bouquet to Forbes, July 11, 1758 in Stephens, Papers of Bouquet, 180.

${ }^{484}$ Accounts of joint expeditions can be found throughout the papers of Forbes and Bouquet. Notable accounts include Forbes to Bouquet, June 16, 1758, Bouquet to Forbes, June 28, 1758, and Bouquet to Forbes, July 11, 1758 in Stephens, Papers of Bouquet, II:104, 143-144, \& 149.
} 
part of 1756 and 1757 turning the Virginia Regiment into a premier provincial unit. Building discipline through regular drill, the young colonel simultaneously claimed his unit equaled any in wilderness combat. As they struggled through the woods in their beautiful blue uniforms, trying to keep up with their lightly-clad Cherokee companions, they must have quickly discovered that they were not equal. Some, such as Lieutenant Colby Chew, adopted the Indian dress wholesale and stripped to a breechclout. Not to be outdone, Washington ordered many of his men to adopt the Indian manner of dress. ${ }^{485}$ Upon hearing of the support of Forbes and Bouquet for his innovation, Washington wrote in relief "[i]t gives me great pleasure to find this Dress; or undress as you justly remark; so pleasing to Colo. Bouquet." ${ }^{486}$ While the transference of native dress certainly did not represent a new trend in 1758 , such large-scale and official adoption certainly had not been seen. Other, more subtle cultural exchanges also began occurring in 1758 .

On June 28, a young soldier from Captain Asher Clayton's Pennsylvania Regiment company stumbled into the British camp at Raystown. Likely after a short recuperation, he told his harrowing tale of a joint scouting mission with the Cherokee. The small band had set out some time before in an attempt to scout Fort Duquesne. Upon reaching the vicinity of the French position, they stumbled upon a party of French and Indians. A largely inconclusive firefight ensued, killing one of the French party. Fearful of encountering French reinforcements, the small Anglo-Cherokee force beat a hasty retreat. The young soldier, however, unfortunately received a snakebite and found himself unable to keep up with his fellows. Unwilling to expose themselves to French retaliation, his Cherokee companions searched the area, provided him with an herbal remedy, and left him to his own devices. ${ }^{487}$ While this account proves extraordinary and unique, it indicates a greater relationship between the two peoples.

${ }^{485}$ For accounts of Washington's training of the Virginia Regiment see Thomas A. Lewis, For King and Country: George Washington the Early Years (New York: John Wiley \& Sons, 1993), chapter 12 and Edward G. Lengel, General George Washington: A Military Life (New York: Random House, 2005), chapter 5. Attempts to dress like Indians can be found in Stephens, Papers of Bouquet, II: 124, 136, 159, 203, 402, 595.

${ }^{486}$ Washington to Ward, July 8, 1758 in Stevens, Papers of Bouquet, 2:240

${ }^{487}$ For the full account see Bouquet to Forbes, June 28, 1758 in Stephens, Papers of Bouquet, 143-144. 
The young man survived his ordeal due to the Cherokee remedy, an experience he probably never forgot and related to others. Other, less-notable exchanges probably occurred as well. If the provincials paid attention, they had much to learn from their Cherokee companions and the joint scouts provided the opportunity to do so. These successful interactions offered the possibility to strengthen CherokeeAnglo relations.

The Cherokee, too, had much to learn from their interaction with Anglo-Americans. Elderly Cherokees might have remembered fighting alongside South Carolinians in the Tuscarora and Yamassee Wars earlier in the century. More recently, some warriors participated in the joint operation during the Sandy Creek Expedition of 1756. 1758, however, represented something different. Here, Cherokees expected to fight alongside a powerful British army possessing the might to sweep the French out of the region. What they got instead was an education in the limitations of a European army in the woods of North America. By June, Cherokee parties had been on the warpath for several months. Although documentation indicates tremendous success on the part of the Cherokee, losses began to mount as well. ${ }^{488}$ On June 10, for example, a notable Cherokee leader died in battle. Only four days earlier, on June 6, had Forbes's regular forces landed in Philadelphia to begin preparations for the campaign. ${ }^{489}$ Under such circumstances, with their high expectations dashed, Cherokee enthusiasm for battle began to wane.

Despite these initial positive interactions, Anglo impressions of their native allies likewise came to be strained through the closer association wrought by the conditions of 1758 . Wracked by incessant raiding from Great Lakes and Ohio Country Indians, the soldiers, particularly those from Pennsylvania and Virginia, began to question the intentions and character of the Native Americans they encountered.

${ }^{488}$ Accounts of Cherokee actions can be found throughout the papers of Forbes and Bouquet as well as the Pennsylvania Gazette. For notable accounts see Trent to Bouquet, June 5, 1758 in Sylvester K. Stevens and Donald H. Kent, eds., Wilderness Chronicles of Northwestern Pennsylvania (Lewisburg, PA: Wennawoods Publishing, 2002), 121-123; Bouquet to Forbes, June 7, 1758, Forbes to Bouquet, June 10, 1758, and Bouquet to Forbes, June 11, 1758 in Stephens, Papers of Bouquet, 47-51, 64-66, \& 74.

${ }^{489}$ Lewis, For King and Country, 157. 
Consequently, some historians point to this Seven Years' War period as the beginning of anti-Indian sentiment in colonial America. The close cooperation and even admiration that sometimes manifested itself on the campaign might have helped dispel the growing sentiment that all Indians represented enemies. Indeed, such a possibility seems realistic at the outset of the campaign. ${ }^{490}$ Forbes himself exclaimed “necessity will turn me a Cherokee, and don't be surprised if I take F: du Quesne at the head of them." ${ }^{491}$ As early as June, however, the opportunity seems to have been passing. Increasingly displeased with his Cherokee allies, Forbes concluded that "[t]he Cherokee are most certainly a very great plague." ${ }^{492}$ Indeed, the Cherokee appear to have reciprocated Forbes's sentiments, as raiding, plundering, and violence escalated in the Virginia backcountry. By the following year, outright warfare broke out between the British and Cherokee. In the end, the shift from a tightening of relations and growth of understanding between these two peoples to outright war seems wildly inconsistent. Yet, the promise of the campaign seems in retrospect fragile, and close interaction instead exposed the vast chasm of differences between the two peoples that ultimately led to war.

To their credit, the British commanders certainly recognized the issue as it developed. They did all in their power to accelerate the army's progress, but as spring turned into summer it became increasingly apparent they could not move quickly enough for the Cherokee. ${ }^{493}$ As they resigned themselves to losing most of the Cherokee, Bouquet found optimism. "The only compensation left to us if they [the Cherokee] leave", he wrote Forbes on June 7, "is that we will no longer be obliged to hurry. ${ }^{\prime 994}$ Cracks began to show as Cherokee warriors fought and died before the glacial British army began to engage the enemy. Disputes over compensation, however, pushed most Cherokee irrevocably towards a more negative relationship with their erstwhile Anglo friends.

\footnotetext{
${ }^{490}$ For the argument about anti-Indian sentiment see Silver, Our Savage Neighbors and for accounts of the positive interactions between Anglos and Indians see Preston, "Make Indians of our White Men."

491 James, Writings, 70-71.

492 John Forbes to Henry Bouquet, June 10, 1758 in Stephens, Papers of Bouquet, II:64.

${ }^{493}$ Forbes to Bouquet, June 10, 1758 in ibid, II: 64-66.

${ }^{494}$ Bouquet to Forbes, June 7, 1758 in Ibid, II: 47.
} 
The Cherokee did not offer their assistance freely and expected adequate compensation and support from the British. Gathering enough goods for Indian allies certainly posed a problem, but misunderstandings on both sides about the symbolism and method of exchange seem to be at the core of the issues that arose. From the British perspective, goods and payment should be exchanged for services. Therefore, payment should only occur after services had been performed. Such a system of reciprocity had not traditionally been a part of Native American culture. Even with the transformative effects of the fur trade economy, Indians still clung to concepts of ritual gift giving between allies. Under such a concept, gifts should have been distributed first as a sign of friendship and goodwill. Any services later performed as allies thus demanded no direct payment at all. ${ }^{495}$

Many of those dealing with the Cherokee completely misunderstood the protocol, leading many to use terms such as "[a]varicious" when referring to the natives. ${ }^{496}$ Captain William Trent, a minor Pennsylvanian officer commanding Fort Loudon, lamented to Bouquet on June 5 that the British should have drawn up contracts with the Cherokee delineating goods for services. ${ }^{497}$ As a prewar Indian trader, Trent should have recognized how alien such a contractual relationship would have been to the Cherokee. Perhaps relying on Trent's "knowledge" of Indian customs, Forbes too later lamented that contracts had not been drawn up, informing Bouquet that "I wish Trents method had been tried at first and a real bargain made with them." 498 Bouquet came up with an additionally absurd proposition. Displaying an utter lack of understanding of native culture, the misguided colonel proposed having "only one storehouse, in which should be deposited the presents from the Provinces (if they give any) and from the King; and by transporting this general storehouse to the place where it is necessary to have

\footnotetext{
${ }^{495}$ For a thorough discussion of this general relationship see Richard White, The Middle Ground: Indians, Empires, and Republics in the Great Lakes Region, 1650-1815 (New York: Cambridge University Press, 1991), chapters 3-4.

${ }^{496}$ Stephen to Bouquet, June 7, 1758 in Stephens, Papers of Bouquet, II:52.

497 Trent to Bouquet, June 5, 1758 in Stephens, Wilderness Chronicles, 121-123.

${ }^{498}$ Forbes to Bouquet, June 10, 1758 in Stephens, Papers of Bouquet, II: 64-66.
} 
Indians, it seems obvious - judging by their greediness - that they would be led there more easily." ${ }^{499}$ The natural Indian "greediness" would thus keep them on task, and on at least one occasion Colonel Armstrong of Pennsylvania and Trent attempted to put such a plan into effect.

Misled by such ridiculous schemes, Forbes mostly preferred to reserve payment until the conclusion of the campaign. Already angered by the army's lack of progress, many Cherokee became enraged at this perceived insult. Some threatened to defect to the French, others to induce their fellows to return home, and in one flamboyant encounter, one band of Cherokee sarcastically gave Trent their bundles and shirts to give back to the general who "loved goods" so much. ${ }^{500}$ Although Forbes initially fretted about the loss of his allies, he seems to have become resigned to the possibility by June. Perhaps he would have been more receptive to Cherokee demands had he feared defection to the French, but intelligence arrived on June 16 indicating French inability to support even their current allies. ${ }^{501}$ Only in the late summer and early fall did Forbes relent. By then, however, he no longer hoped to maintain the allegiance of most of the Cherokee. Instead, the general simply attempted to purchase the good behavior of Cherokees bent on destruction as they passed through Virginia on their route home. $^{502}$

The abject mismanagement of Indian affairs by British and colonial officers in 1758 reveals a deep misunderstanding of native culture that seriously damaged the alliance. Yet, if the British officers did prove culpable in the mismanagement of the Cherokee, they once again displayed sensitivity to their shortcomings. Bouquet, a Swiss mercenary veteran of many European campaigns, particularly recognized his limitations. Writing to Forbes on June 3, he admitted "I do not know anything about the

${ }^{499}$ Bouquet to Forbes, June 3, 1758 in Ibid, II: 15.

${ }^{500}$ Armstrong to Forbes, May 18, 1758 in FP, GD 45/2/68-81, SNA; Trent to Bouquet, June 5, 1758 in Stephens, Wilderness Chronicles, 121-123.

${ }^{501}$ Forbes to Bouquet, June 16, 1758 in Stephens, Papers of Bouquet II: 104.

${ }^{502}$ See Forbes to Fauquier, August 16, 1758 in Reese, OPFF, I: 59-60 and Forbes to Pitt, September 6, 1758 in Kimball, Correspondence of William Pitt, 338. See also Ward, Breaking the Backcountry, 167. 
way Indians are managed. ${ }^{\prime 503}$ Nearly two weeks later, he reiterated his concerns to his commander, noting "I am not familiar enough with their [Cherokee] manners and customs." ${ }^{504}$ With his primary subordinate pleading ignorance, the general found himself forced to cope as best he could. He did, however, receive useful advice from the tentative Bouquet. The colonel had been able to identify a problem with the current situation, where a numerous assortment of people had involved themselves in dealing with the Indians. Men such as Adam Bosomworth, William Byrd, Alexander Stephen, William Trent, and many others had inconsistently dealt with the native allies. ${ }^{505}$ "The variety of measures which have been taken [regarding the Cherokee] has done much harm," Bouquet noted, "as well as the presents given by different hands and in different places." "I believe everything concerning them [the Cherokee]," he went on, "should be turned over to a single person who would account to you for everything." ${ }^{506}$ Forbes agreed with the sentiment, but failed to settle on the "single person." 507

In his search, the general possessed several viable options. Initially, as he had done with regards to the discussions at Easton, he turned to the officially recognized British Indian agents-William Johnson and Edmund Atkins. Both, however, proved disinclined to offer Forbes any meaningful assistance. In disgust, the general lamented " $[A]$ nd I must say that it was astonishing to me, to see the greatest body of Indians ever assembled in our Service, totally neglected by the two Gentlemen [Johnson and Atkins] employed by the Government for the management of the Indians." 508 Johnson found himself consumed by management of the Iroquois Confederacy as it assisted in the northern campaigns and unlike his failure to assist Forbes with Pennsylvania's native neighbors, his negligence

\footnotetext{
${ }^{503}$ Bouquet to Forbes, June 3, 1758 in Stevens, Papers of Bouquet, 15.

${ }^{504}$ Bouquet to Forbes, June 16, 1758 in Ibid, 96.

${ }^{505}$ Stephen to Bouquet, June 6, 1758, Stephen to Bouquet, June 7, 1758; Bouquet to Forbes, June 11, 1758
} in ibid.

${ }^{506}$ Bouquet to Forbes, June 3, 1758 in Ibid, 15.

${ }^{507}$ For discussion of Forbes struggle see Ward, Breaking the Backcountry, 167 and John Oliphant, Peace and War on the Anglo-Cherokee Frontier, 1756-1763 (Baton Rouge, LA: Louisiana State University Press, 2001), 56.

${ }^{508}$ Quoted in Oliphant, Peace and War, 61. 
with the southern Indians can be understood. The general, however, continued to demand assistance. Abercromby found him "still complaining of your not having gone or sent some one to take the care and management of the Cherokees." ${ }^{\prime 509}$ Perhaps Forbes had been confused by the complex situation he found himself in, because the Cherokees resided in Atkin's department but in 1758 operated as allies within the geographic boundaries of Johnson's department. The establishment of superintendencies in North America thus did not always clearly delineate authority over diplomacy with the natives.

He also recognized, at the same time, the superintendent's general desire to have control over Indian affairs. When contemplating who the best person was to handle the Indians in the absence of Johnson, Forbes wrote Bouquet that "I do not yet know ... how farr Sir. William Johnston will intermeddle." ${ }^{\prime 510}$ Complicating the situation, the Commander-in-Chief wrote Johnson "that you cou'd not possibly interfere with the Cherokees, as not being within your department." ${ }^{1511}$ In fact, Johnson did get involved in Cherokee affairs in Pennsylvania, mediating disputes and overseeing meetings between the southern visitors and representatives of the Iroquois Confederacy. He further collaborated with Atkin, informing Abercromby that "I am sending [a copy of the proceedings]to Mr. Atkins as I judge it proper \& necessary that he shoud be apprizd of what has past here, that he may co-operate therewith as far as his Influence extends." ${ }^{512}$

Atkin proved to be even more difficult than Johnson had been for Forbes to track down in 1758. Atkins's absence, however, remains perplexing. In 1757, the agent had demanded from the Cherokee a personal monopoly on dealing with them. ${ }^{513}$ Even the Virginia Council, who frequently competed with South Carolina for influence with the Cherokee, conceded to Atkins's authority in $1757 .{ }^{514}$ With oversight of the Southern Department, moreover, the diplomat should have been involved in this most

\footnotetext{
${ }^{509}$ Abercromby to Johnson, July 23, 1758 in Knoblauch, Johnson Papers.

${ }^{510}$ Forbes to Bouquet, June 6, 1758 in Stevens, Papers of Bouquet, II:39-40.

${ }^{511}$ Abercromby to Johnson, July 23, 1758 in Knoblauch, Johnson Papers.

512 Johnson to Abercromby, August 12, 1758 in ibid.

513 Atkin to Old Hop, August 21, 1757 in Mays, Amherst Papers, 20.

${ }^{514}$ Virginia Council, May 3, 1757 in Ibid, 15.
} 
important of affairs. Yet, he played only a minor role. It seems likely, therefore, to assume that Atkins found himself preoccupied by violent encounters between Cherokees and Virginians increasingly occurring to the southward. He may also have stayed away as a consequence of his personal interests in South Carolina. Only once did Forbes refer to assistance rendered by the superintendent. Instead, Atkin's principal lieutenant, Christopher Gist, presumably represented the Southern Department's interests with the Cherokee in Pennsylvania. Leaving the matter in the hands of Gist made geographic sense because the deputy resided in Maryland. Assuming command of Indian affairs in Winchester, Virginia, the deputy agent proceeded to gather and provide supplies for native allies arriving from the southward. He generally sought to comply with the principal figures concerned in the campaign in his locale, communicating closely with Colonel George Washington, Sir John St. Clair, and Governor Fauquier. ${ }^{515}$ To exert his authority, Gist signed his letters “Deputy Agent for Indian Affairs in the southern District North America." ${ }^{516}$ For his part, Washington appears to have recognized Gist's preeminence, but others remained dubious. ${ }^{517}$ The deputy complained incessantly to St. Clair about funds, he quarreled with Fauquier, and refused to leave Winchester to associate more directly with Cherokee in Pennsylvania. ${ }^{518}$ Although Gist's peculiar behavior might be attributable to an illness that took his life not long after the campaign, former governor of South Carolina and cousin of Forbes, James Glen, insisted that the agent had come under the influence of interested parties. "I fear the poor fellow," he confided to his cousin, "has fallen into bad hands."

${ }^{515}$ Forbes to Dobbs, March 21, 1758 in Stewart, Letters of Forbes, 10; Gist to St. Clair, April 12, 1758 in FP, GD 45/2/37-39, SNA.

${ }^{516}$ Gist to St. Clair, April 12, 1758 in FP, GD 45/2/37-39, SNA.

${ }^{517}$ Washington to Fauquier, September 2, 1758 in Reese, OPFF, 1:67-68. It should be noted that Washington had previous association with Gist, and while their relationship was not necessarily close, the colonel was perhaps in a better position to judge the deputy agent than some of his detractors.

${ }^{518}$ Fauquier to Washington, September 16, 1758; Gist to Fauquier in ibid, I:35 \& 72; Gist to St. Clair, April 12, 1758 in FP, GD 45/2/37-39, SNA.

${ }^{519}$ Glen to Forbes, July 13, 1758 in FP, GD 45/2/40-44, SNA. 
In place of the superintendents, Forbes turned once again to the colonial governments for assistance. Maryland and North Carolina played minimal roles. The general reached out to Governor Sharpe of Maryland to do what he might in his province while he requested from Governor Dobbs of North Carolina protection for the Cherokee as they travelled through his colony on their way north. ${ }^{520}$ In Pennsylvania, he signaled his interest in knowing Governor Denny's "[o]pinion of the Party of Cherokees at Carlisle ... [and] how far the Province thinks themselves obliged to take Care of those Indians by Presents, Cloathing, \&ca." ${ }^{251}$ More focused on native issues closer to home, the Pennsylvania Assembly responded minimally, agreeing to support a total of thirteen Cherokee warriors. ${ }^{522}$ Generally, however, Pennsylvanian officials remained aloof from managing the southern native allies. Colonel Armstrong's sentiments prove representative of Pennsylvania's outlook on the Cherokee. "I'm of opinion that with all possible dispatch," he advised Forbes, "the Chiefs, and head Warriors of those Indians ... \& the Governmts. Of Virginia \& Maryland shou'd be conven'd \& the best indeavours us'd to stipulate something with them relative to the Expedtion." "[A]t which interview," he continued, "your own presence wou'd have great efficacy." ${ }^{523}$ Armstrong thus considered the Cherokee the responsibility of southern colonies or the British military. South Carolina and Virginia, then, became the natural sources of authority on Cherokee affairs.

Unable to spare any troops for the campaign, South Carolina assisted as it could, drawing upon its long and generally friendly relationship with the Cherokee to recruit new warriors and smooth over the differences that had begun to emerge. The province invited influential Cherokee leaders to Charlestown, using the King's birthday as an opportunity to impress them with the might of British arms. South Carolina also provided several excellent candidates for assuming the direction of managing affairs

\footnotetext{
${ }^{520}$ Forbes to Dobbs, March 21, 1758; Forbes to Pitt, May 1, 1758 in Stewart, Letters of Forbes, 9-10 \& 14.

${ }^{521}$ Forbes to Denny, May 3, 1758 in ibid, 17.

522 June 21, 1758 in Cox-Parrish-Wharton Papers, 154, Series 4, Box 14, Folder 15, HSP.

${ }^{523}$ Armstrong to Forbes, May 18, 1758 in FP, GD 45/2/68-87, SNA.
} 
with the Cherokee in the north - former governor James Glen and Adam Bosomworth, an officer in the $60^{\text {th }}$ Royal American Regiment. Current governor William Henry Lyttleton continued to do what he could from Charleston. ${ }^{524}$

James Glen had until recently been the governor of South Carolina and prided himself on his ability to maintain good relations with the neighboring Cherokee. On at least one occasion, Glenn travelled five hundred miles sleeping constantly in the woods to meet with the Cherokee near their villages in 1748 rather than demand that they travel the difficult journey to the provincial capital as many other governors had done. In a letter to the Board of Trade, the governor described the many difficulties Cherokee delegations confronted while traveling to and from Charleston. Some Cherokee villages existed too far away, some had to travel through dangerous Creek territory, others complained of the difficulty of transporting trade goods back to their villages, and yet others indicated that they used up all the gifts of ammunition to hunt in an effort to feed themselves on the way home. All reported the fear of leaving their homes undefended for the time required to make the long journey, and intimated that if forced to travel to the capital they might more easily deal with French outposts more closely situated to their villages. ${ }^{525}$ Glen's policy thus clearly represented an effort to recognize and observe the concerns of South Carolina's native neighbors and allies, and he took pride in the astuteness of his actions. "I shall not arrogate the whole to my self, I had the advice of the Council and assembly in most of the measures I pursued," he informed the Board of Trade, "but it were false modesty to say that I have done nothing." ${ }^{526}$

${ }^{524}$ Lyttleton to Forbes, May 21, 1758 in FP, GD 45/2/37-39; Lyttleton to Fauquier, August, 1758, Enclosure: Council Journal, October 12, 1758, Lyttleton to Fauquier, November 1, 1758, Enclosure: Journal of the council of South Carolina, November 8-16, 1758; Lyttleton to Fauquier, December 7, 1758 in Reese, OPFF, 1: 56$57,91,98, \& 119-121$.

${ }^{525}$ Glen to Board of Trade, April 23, 1748; Glen to Lords Commissioners for Trade and Plantations, January, 1749 in FP, GD 45/2/1, SNA.

${ }^{526}$ Glen to Lords Commissioners for Trade and Plantations, January 1749 in FP, GD 45/2/1, SNA. 
The governor's sincere willingness to look out for the best interests of his colony's native allies appears further confirmed by a 1752 letter to the Board of Trade arguing for the construction of several fortifications in Cherokee territory. Along with several factors that directly benefitted South Carolina and by extension the British Empire, Glen argued that the forts served to "protect Indians." Presumably, Glen's favorable actions towards the southern Indian allies of Great Britain as governor of South Carolina had endeared him with those peoples and his presence with Forbes might have been a tremendous asset to the campaign's efforts to reach the Forks. His connections with the Board of Trade, and likewise members of the ministry with whom he had corresponded while governor, might have also given Forbes additional support in the long-term should he succeed in his campaign. ${ }^{528}$

At the outset of the 1758 campaign, Glen took it upon himself to assist as he could. "Mr. Glen . . . hearing of the Defection and falling off, of the Cherokees," Forbes informed Bouquet, "went off into the back Countrys directly. ${ }^{\prime 529}$ In addition, the former governor dispatched representatives to the Cherokee to assist in recruiting warriors. Forbes embraced the opportunity to utilize Glen as an intermediary, informing Bouquet of his decision on June 10. Initially, the general possessed high hopes for his cousin's abilities. ${ }^{530}$ To Secretary of State Pitt, Forbes wrote "as he has had formerly great dealings with them, I am persuaded his personall Interest among them, contributed greatly at this present time in making them do whatever is desired."531 "I have got Govr. Glen to write to the Cherokees as he had Certainly great knowledge of them," he likewise wrote to Bouquet, "and will go up to endeavour to keep them so.." ${ }^{532}$ On June 14, Bouquet responded with high hopes for Glen's ability,

${ }^{527}$ Glen to Lords of Trade, July, 1752 in ibid.

${ }^{528}$ Glen to His Grace the Duke of Dorct., Lord President of His Majesty's Council, ND in ibid.

${ }^{529}$ Forbes to Pitt, July 10, 1758 in Stewart, Letters of Forbes, 26.

${ }^{530}$ Forbes to Bouquet, June 10, 1758 in Stevens, Papers of Bouquet, II: 64-66.

${ }^{531}$ Forbes to Pitt, July 10, 1758 in Stewart, Letters of Forbes, 26.

${ }^{532}$ Forbes to Bouquet, June 10, 1758 in Stevens, Papers of Bouquets, II:65. 
likewise concluding "that his presence would have a good effect on his old friends." ${ }^{533}$ Forbes, however, came to doubt the usefulness of his cousin.

On June 27, he broke the news to Bouquet, saying "I do not see that Governour Glen can be of any great service." ${ }^{534}$ Switching to French, a language both officers knew well and at times used to ensure some measure of privacy, confided that he simply accepted his cousin's offers of assistance out of politeness. ${ }^{535}$ Yet, despite the private sentiments Forbes shared with Bouquet about the services of Glen, he clearly continued to hold his cousin in high esteem. Upon Forbes's untimely death in March 1759, Glen inherited the general's North American possessions and became the executor for the remainder of his estate. The rapid decline in the trust Forbes retained for the ability of Glen to assist him in the campaign might best be explained by intrigue. Letters written by Glen to Forbes questioned the talents of William Byrd, a high ranking Virginian officer who likewise attempted to establish himself as Forbes's principle manager of the southern Indians. ${ }^{536}$ Byrd conversely disapproved of Glens actions, leading the former governor to express his surprise to Forbes. "I know he has more honour and better sense than not to wish some hundred more Indians here tho he could not bring them," Glen wrote Forbes. ${ }^{537}$ Glen and Byrd had developed a rivalry, and Forbes began to favor Byrd. In responding to Bouquet's suggestion that one man should oversee all interactions with the southern Indians, Forbes responded "I agree that the Indians ought to be under the direction and manadgement of one person, and for that purpose think Colo. Bird of Virginia would be the properest." ${ }^{538}$ Despite this ringing endorsement, South Carolinians continued to figure into the plans of Forbes.

Besides Glen, Abraham Bosomworth emerged as an additional South Carolinian candidate to manage the southern Indian allies. Bosomworth's parents, Thomas and Mary, had long been intricately

\footnotetext{
${ }^{533}$ Bouquet to Forbes, June 14, 1758 in Ibid, II: 89.

${ }^{534}$ Forbes to Bouquet, June 37, 1758 in Ibid, II: 137.

535 Ibid.

${ }^{536}$ Will, March 24, 1759 in FP, GD 45/2/97, SNA.

${ }^{537}$ Glen to Forbes, July 13, 1758 in FP, GD 45/2/40-44, SNA.

${ }^{538}$ Forbes to Bouquet, June 6, 1758 in Stevens, Papers of Bouquet, II:39-40.
} 
involved in South Carolina's Indian affairs. Mary came from a mixed heritage, born to an Anglo father and Creek mother. Married to a succession of Anglo husbands, she had become an important mediator between South Carolina and its native neighbors. With this lineage behind him, Abraham had risen to become South Carolina's Agent for Indian Affairs by at least $1752 .{ }^{539}$ These political connections, along with the stationing of the $60^{\text {th }}$ Regiment in South Carolina, led to Bosomworth's commission as an officer in that regiment for the impending campaign. Meant to be a regiment that would encourage the enlistment of Germans residing in Great Britain's North American colonies, the officers were ideally to be comprised of German and Swiss professionals from Europe. Bosomworth's appointment thus was not the norm, but it did mean that he was technically a regular and not a provincial officer. This status in the $60^{\text {th }}$ initially enamored him with Forbes and Bouquet, who commanded the 60th. As one of their own, they could presumably trust his loyalty to the crown and not an individual colony.

Upon arriving on the scene, the Indian agent quickly established himself as a principle player in dealing with the Southern Indians. In April, he arrived in Winchester where Gist presumably had assumed charge of Indian affairs. From there, he assumed the dispensing of gifts and the recruitment of warriors. ${ }^{540}$ Those closely observing Bosomworth's actions appear to have supported him. In May, Colonel Armstrong of Pennsylvania informed Forbes that "I find he has had proper instructions \& understands the medium. ${ }^{1541}$ Bouquet in particular supported the agent, strongly hinting to Forbes that Bosomworth should be favored. ${ }^{542}$ While Forbes and Bouquet came to agree that one man should be

\footnotetext{
${ }^{539}$ Memorial of Mr. Bosomworth on behalf of himself and wife, April, 1752 in Lucian Lamar Knight, ed., The Colonial Records of Georgia, Vol. 26 (Atlanta, GA: Chas P. Byrd State Printer, 1916).

${ }^{540}$ Blair to Forbes, April 9, 1758 in FP, GD 45/2/40-44, SNA; Bouquet to Forbes, June 3, 1758, Trent to Bouquet, June 5, 1758, St. Clair to Bouquet, June 9, 1758, Bouquet to Forbes, June 14, 1758; Bosomworth to Bouquet, June 16, 1758 in Stevens, Papers of Bouquet, II: 15,36-36, 61, 89, \& 92.

${ }_{541}$ Armstrong to Forbes, May 18, 1758 in FP, GD 45/2/68-87, SNA.

${ }^{542}$ For Bouquet's support of Bosomworth see Bouquet to Forbes, June 3, 1758, Bouquet to Forbes, June 7 , 1758, Bouquet to Forbes, June 16, 1758, and Bouquet to Forbes, July 11, 1758 in Stevens, Papers of Bouquet, II: 15, 47-51, 96, and 181 .
} 
authorized to deal with the Indians, they disagreed on the individual. Forbes favored Byrd while Bouquet leaned towards Bosomworth, noting:

I should not dare recommend anyone in such a delicate matter, but since the agents or superintendents are leaving you, it seems to me that you will be obliged to take care of their duties. If Bosomworth succeeds in retaining the Cherokees, and can lead them to Fort Loudoun or Reas Town, wouldn't he be more suitable than Gist to manage them during the campaign? $?^{533}$

The colonel continued to laud Bosomworth, writing to Forbes on June 7 about "[ $t$ ]he success Bosomworth has." ${ }^{544}$

Little more than a week later, Bouquet further informed his commanding officer that "I must give justice to Bosomworth. It is to him principally that this success is due." ${ }^{545}$ The less than subtle endorsements did not sell Forbes, because he had apparently been warned about the trustworthiness of the South Carolinian. "I do not yet know how farr we can trust to Mr. Bossomworth," he informed Bouquet in early June, "but keep this to yourself and make the best of it in the mean time." 546 Later in June, the general further warned his enthusiastic subordinate "Bosomworth I am sensible has been of service but you must not believe all he says." ${ }^{547}$ In an apparent attempt to remove Bosomworth from Indian affairs without insult, Forbes recommended him as a Brigade Major in July. ${ }^{548}$ The appointment never followed, however, because he had been "found to be too deeply engag'd in Indian Affairs." 549 The conclusions by Armstrong and Bouquet, who operated in the field alongside Bosomworth, suggested that the agent conducted himself well with regards to the southern Indians but Forbes, who

\footnotetext{
${ }^{543}$ Bouquet to Forbes, June 3, 1758 in ibid, II: 15.

${ }^{544}$ Bouquet to Forbes, June 7, 1758 in ibid, II: 49-50.

${ }^{545}$ Bouquet to Forbes, June 16, 1758 in ibid, II: 96.

${ }^{546}$ Forbes to Bouquet, June 6, 1758 in ibid, II: 39-40.

${ }^{547}$ Forbes to Bouquet, June 27, 1758 in Ibid, II: 137.

${ }^{548}$ Byrd to Fauquier, July 21, 1758 in Reese, OPFF, I: 55.

${ }^{549}$ Washington to Fauquier, September 2, 1758 in ibid, I: 67.
} 
generally trailed far behind the army's progress, had arrived at the opposite opinion. Such a disparity seems to suggest that, like Glen, somebody had deliberately attempted to undermine Bosomworth's esteem with the general.

While Glen and Bosomworth strove to assist Forbes with the southern allies in the field, South Carolinia's Governor Lyttleton worked assiduously from Charlestown to maintain the alliance with the Cherokee as it began to unravel during 1758 . The alliance had become threatened by the endemic war being waged between western Virginians and native peoples dating back to 1755 when General Braddock's army had been defeated. Presumably, Great Lakes and Ohio Country Indians perpetrated the raids. Indeed, some historians have conjectured that such raiding attempted to cut the communication between the Cherokee and their colonial allies. ${ }^{550}$ While these attacks from natives allied with the French might have been expected, Virginians began reporting Cherokee depredations in the western settlements of the province. ${ }^{551}$

Cherokee attacks on Virginian settlements during and prior to 1758 prove illogical at first glance. Even accounting for the wide variety of Cherokee interests, blatant hostility towards Virginia would have seriously compromised the situation of those warriors active in the campaign far to the north. The Cherokee knew better. Instead, several alternatives suggest themselves. First, tales of Cherokee hostility may merely represent gross exaggeration. The long trip from Cherokee country to northern Virginia and Pennsylvania presented serious logistical issues for natives. Faced with the options of hunting or foraging, the latter likely proved easier and more efficient. In fact, hunting may not have even been an option for some. Expecting to be supplied by the British for war, at least some Cherokee arrived without weapons at all. ${ }^{552}$ If foraging did occur, colonists may have felt unduly threatened. Subjected to years of terrifying Indian raids, confronted with allies suspiciously similar to enemies, and

\footnotetext{
${ }^{550}$ See Ward, Breaking the Backcountry, 50, 60, and 166.

${ }^{551}$ For an example see Reade to Dinwiddie, April 9, 1757 in Mays, Amherst Papers, 8.

${ }^{552}$ See James, Writings, 77.
} 
likely subject to a language barrier, colonists could have easily exaggerated these "hostile" interactions. They might also have exuded fear when confronted by natives, be they friend or foe, leading the Cherokee travelers to more confidently take advantage of the situation. According to Fauquier, "the Indians are too well convinced that in general the people are afraid of them, and commit many Outrages upon that Principle, as I apprehend." ${ }^{553}$

Historians have also suggested that Cherokee violence may have been a case of mistaken identity. Unable to distinguish friend from foe, provincials projected enemy violence on the Cherokee. "We some times heard of Mischief done by some Indians," Fauquier announced, "but of what Nation we were ignorant.." ${ }^{554}$ In fact, Great Lakes and Ohio Country Indians may have fostered cases of mistaken identity by pretending to be Cherokee. ${ }^{555}$ Fauquier came to a similar conclusion, noting:

The Indians on their March often practiced this Devise, If they saw any arm'd Men able to oppose them they call'd themselves Cherokees and shook Hands as Brothers if only Women, Children or an inferior Force were in view the same party would call themselves Shawnese and immediately fall to plundering, killing and scalping. It is impossible to distinguish the Nations of Indians. ${ }^{556}$

In addition, the governor identified bands of renegade Indians, attached to no tribe, as perpetrators. ${ }^{557}$ Convinced of Cherokee innocence, Fauquier attempted to avoid outright war through a herculean effort and visionary restraint so often absent in European-Indian affairs.

Wary of what his citizens might do, the governor took what action lay at his disposal. On June 6 , he informed St. Clair that he had strictly forbade the Virginia militia to retaliate against the Cherokee. ${ }^{558}$ By October, he rescinded the colony's scalp bounties, hoping to curb individual incentive to produce any

${ }^{553}$ Fauquier to Lyttleton, October 13, 1758 in Reese, OPFF, 1:89.

554 Ibid.

${ }^{555}$ See Ward, Breaking the Backcountry, 166.

${ }^{556}$ Fauquier to Lyttleton, October 13, 1758 in Reese, OPFF, I: 89.

${ }^{557}$ See Fauquier to Lyttleton, June 16, 1758 in Ibid, I: 29.

${ }^{558}$ Fauquier to St. Clair, June 6, 1758 in Ibid, I: 16. 
scalp for monetary recompense. "[P]erhaps our Reward for Scalps may have done mischief," he wrote Lyttleton, "therefore We have now repealed it." ${ }^{559}$ To further encourage circumspection, Fauquier provided financial restitution to those settlers who claimed Cherokee theft. Not all were assuaged, however, and some continued to aggressively attack Cherokee parties. ${ }^{560}$

Virginia's governor, with the blessing of Forbes, additionally reached out to his counterpart in South Carolina to stem the tide of violence by drawing upon that colony's longstanding friendship with the Cherokee people. Fauquier's correspondence with Lyttleton demonstrates the extent to which Virginia had become dependent on the intervention of South Carolina. "His Honor was also advised to write to Govr. Lyttleton," Virginia's Council recorded, "to request he will still exert his Influence and Power to effect a Reconciliation." ${ }^{561}$ Fauquier accepted this advice, informing Lyttleton that Virginia required his assistance because "you have more Influence than any other person." ${ }^{562}$ Fauquier concurrently appeared to yield to South Carolina's preeminence in diplomacy with the Cherokee, wishing that Lyttleton "will not think I have made any Infringement of your Right." ${ }^{\text {"63 }}$ According to the Virginian governor, South Carolina could be of most use by contacting the Cherokee and clearly explaining the unfortunate source of the conflict. Towards that end, Fauquier presented his counterpart with a detailed description of the misunderstandings that had occurred between the erstwhile allies and requested that Lyttleton assure the Cherokee that any restitution required would be made by Virginia. ${ }^{564}$ Fauquier closed by expressing "the least doubt [in] your Assistance in the present unhappy situation of Affairs." ${ }^{1565}$

\footnotetext{
${ }^{559}$ Fauquier to Lyttleton, October 13, 1758 in Ibid, I: 89.

560 Ibid.

${ }^{561}$ Enclosure: Council Journal, October 12, 1758 in ibid, I:92.

${ }^{562}$ Fauquier to Lyttleton, June 16, 1758 in ibid, I:29.

${ }^{563}$ Fauquier to Lyttleton, October 5, 1758 in ibid, I:84.

${ }^{564}$ Fauquier to Lyttleton, June 16, 1758, Fauquier to Lyttleton, October 5, 1758; Fauquier to Lyttleton,
} October 13, 1758 in ibid, I:29,84 \& 90.

${ }^{565}$ Fauquier to Lyttleton, October 13, 1758 in ibid, I:89. 
South Carolina, led by Governor Lyttleton, proved more than willing to intervene. He gathered intelligence about the sentiments of the Cherokee, determining that their reason for attacking Virginia "was that they had received Intelligence that divers of their People had been lately killed by some of the Inhabitants of that Colony." ${ }^{566}$ Lyttleton consequently attempted to placate the Cherokee in various ways. $^{567}$ In attempting to explain what had occurred, the governor declared:

That what has been done against them, was in Violation of those Commands [of Fauquier], and ought to be imputed to the Rashness of a few disorderly Men, but by no means to be consider'd as any Act of the Government or regarded as a just Cause of War between the two Nations; that Endeavors have been used in vain to apprehend and punish the Offenders; promising them all possible Satisfaction if they will call back their Parties already gone out, and prevent the Effusion of more Blood. ${ }^{568}$

When all else failed, Lyttleton threatened the colony's most steadfast allies, reminding them of the might of Great Britain. ${ }^{569}$ The governor dutifully relayed his results back to his Virginian counterpart, who responded that the leaders of the province "are much obliged to you for your Information." 570 Despite the appearance of collegiality, Virginians interested in western lands and trade with the Indians must have been unsettled by Lyttleton's caveat that the Cherokee preferred to deal with South Carolina rather than Virginia. ${ }^{571}$

By 1758, Virginia's expansionist ambitions had, in part, put itself in the position to run into conflict with the Cherokee, and its subsequent diplomatic interests ran counter to those of the South

${ }^{566}$ Enclosure: Journal of the Council of South Carolina, November 8-16, 1758 in ibid, I:121.

${ }^{567}$ Enclosure: Council Journal, October 12, 1758; Enclosure: Journal of the Council of South Carolina, November 8-16, 1758 in ibid, I:92 \& 121-122.

${ }^{568}$ Enclosure: Council Journal, October 12, 1758 in ibid, I:92.

${ }^{569}$ Enclosure: Journal of the Council of South Carolina, November 8-16, 1758 in ibid, I:124.

${ }^{570}$ Fauquier to Lyttleton, October 13, 1758 in ibid, I:89.

${ }^{571}$ Lyttleton to Fauquier, September 26, 1758 in ibid, I:80-81. 
Carolinian government. ${ }^{572}$ Although colonies such as Pennsylvania and South Carolina certainly had negative encounters with their native neighbors in the past, the provinces had attempted to maintain some semblance of equity and friendship. Virginia, on the other hand, had become more avaricious at an earlier period with regards to the natives because it had developed a more powerful and organized interest group intent on exploiting western territories in the form of land companies, most notably the Ohio Company.

In a June letter written to the Board of Trade, Fauquier described the violence ongoing in the colony's western settlements. Despite the establishment of Indian Superintendents and the presence of military officers just to the north, the governor made it clear that Virginia neither required nor desired British intervention. Instead, Fauquier indicated that representatives from the Ohio Company had been dispatched to quell the disturbances. ${ }^{573}$ While the motivations of the Friendly Association in Pennsylvania might be questioned to a degree, they certainly demonstrated a significant degree of concern for the well-being of the Indians in their actions. The same cannot be said for the Ohio Company.

George Washington, a member of the Company, clearly identified elite Virginian views of the natives. "A Trade free, open and upon equitable terms, is what they [Indians] seem much to stickle for;" he informed the governor," and I do not know so effectual a way of riveting them to our interest, as sending out Goods immediately to this place for that purpose." ${ }^{574}$ He continued:

That a Trade with the Indians should be upon such terms . . .as would at the same time turn out to the reciprocal advantage of the Colony and the Indians . . . and give us such an early opportunity of establishing an Interest with them as would be productive of the

\footnotetext{
${ }^{572}$ For a discussion of Virginian policy towards the Cherokee, see chapter five in Boulware, Deconstructing the Cherokee Nation.

${ }^{573}$ Fauquier to Board of Trade, June 11, 1758 in Reese, OPFF, I:54.

${ }^{574}$ Washington to Fauquier, November 28, 1758 in ibid, I:116.
} 
most beneficial consequences, by getting a large share of the Fur-trade, not only of the Ohio Indians, but, in time, of the numerous nations possessing the backs countries westward of it. ${ }^{575}$

To be fair, Israel Pemberton had individually undertaken a similar endeavor and been reprimanded by the Friendly Association. Washington's language, however, demonstrates much more design. He correctly assessed the native desire for trade, but emphasized more thoroughly how that trade might benefit Virginia, and by default the Ohio Company, strategically. A set of disparate statements issued by Fauquier perhaps more clearly demonstrates many elite Virginians' view of its native neighbors. At the height of Cherokee-Virginian hostility, the governor utilized diplomatic verbiage when he dispatched a messenger to the Cherokee informing them that "the Cherokees ... we esteem'd our Friends." ${ }^{576}$ Just three months earlier, in private correspondence to Washington, the very same man stated "I have never entertain'd any high Opinion of the Friendship of any Indians, nor from'd any great Expectations from their Service."

The Virginians wanted to shape their own policies towards the Indians and Fauquier, as governor, led the way. As he fretted about the growing hostility between Virginian settlers and Cherokees, Fauquier went to extreme lengths to minimize the conflict. He repealed the aforementioned scalp bounty to ensure that Virginians did not have an incentive to kill Cherokees, and issued strict orders to Virginian officials and militia officers that the warriors should not be molested on their passage through the county. When Virginians did attack and succeed in chasing off Cherokee travelers, the governor attempted to repair the damage by returning to the natives any goods confiscated. ${ }^{578 ~ "[T] h e}$ Governour had even gone so far," the South Carolinian Council noted, "as to order the last Booty taken

${ }^{575}$ Washington to Fauquier, December 2, 1758 in ibid, I:117-118.

${ }^{576}$ Enclosure: Council Journal, October 12, 1758 in ibid, I:91-92.

${ }^{577}$ Fauquier to Washington, July 20, 1758 in ibid, I:53.

${ }^{578}$ Fauquier to Lyttleton, June 16, 1758, Robert Winn to Fauquier, October 1758, Fauquier to Lyttleton, October 13, 1758, Enclosure: Journal of the Council of South Carolina, November 8-16, 1758; Fauquier to John Buchanon, November 14, 1758 in ibid, I: 29, 82-83, 90, $105 \& 122$. 
in a Skirmish with them [the Cherokee] by some of his People, to be deposited in a proper Place that it might be delivered to them if demanded." ${ }^{579}$ If South Carolina approved of Fauquier's actions, it only derived from its desire for peace, because even as the governor had turned to his South Carolinian counterpart for assistance with the Cherokee, he began undermining South Carolina by attempting to host various Cherokee headmen in Williamsburg. ${ }^{580 ~ " I n ~ o r d e r ~ t o ~ d o ~ a l l ~ i n ~ o u r ~ P o w e r ~ t o ~ s a t i s f y e ~ t h e ~}$ Cherokee Nation," Fauquier informed Lyttleton, "we propose sending a Messenger into the Country with Letters assuring them of our Intentions, and to invite some of their grave discreet Chiefs to Williamsburgh to settle these Disputes amiacably." ${ }^{151}$

Although Lyttleton and experienced South Carolinian diplomats might have sardonically noted that Virginia doing "all in our Power" might best have been realized by it sitting on the sidelines while the colony with more historical connections to the Cherokee took the lead in negotiations, Fauquier's behavior might have been inadvertently prodded by British officers. Early in the campaign, as the officers struggled to manage their native allies in Pennsylvania, they reached out to Virginia. In a letter to Washington, Bouquet noted that "I shoud be obligd to propose the thing [a message to the Catawba] to the Governor of Virginia.. ${ }^{582}$ Perhaps Virginia meddled in South Carolina's traditional relationship with the Cherokee out of a sense of duty and obligation to the wishes of the British officers. The colony's interest in western lands and Cherokee trade, however, suggests more avaricious motives.

Fauquier's answer to British requests that he attend the conference at Easton seems to confirm the latter assessment. In August, Forbes personally informed the governor of Virginia:

After a variety of Intrigue and manadgment I have at last brought about a Convention of most of the Indian Nations friends \& foes to meet all the Governors at East town in

\footnotetext{
${ }^{579}$ Enclosure: Journal of the Council of South Carolina, November 8-16, 1758 in ibid, I:123.

${ }^{580} \mathrm{Ibid}$; Fauquier to Lyttleton, October 13, 1758 in ibid, I: 90 \& 123.

${ }^{581}$ Fauquier to Lyttleton, October 13, 1758 in ibid, I:90.

582 Washington to Fauquier, July 10, 1758 in ibid, I:51.
} 
Pensylvania about the $10^{\text {th }}$ of Septr. There to settle and finish all Complaints, and if possible by doing the Indians justice to make them our Friends, which from their demands I do think easily Done, as it would be a great stroke, so make no doubt of your being invited there. ${ }^{583}$

Perhaps recognizing the competitive nature of colonial relations with native peoples, the general specifically requested that Denny contact his Virginian counterpart, which he did at the end of the month. Fauquier promptly declined attending the conference. ${ }^{584}$

While it might justly be noted that Virginian affairs with the Cherokee demanded the governor's attention in the fall of 1758 , his refusal to attend such an important conference appears curious. Virginia possessed little interest in Pennsylvania's relationship with the Susquehanna Delaware, but the colony should have been particularly interested in the negotiations being held with the Ohio Indians as it intended to compete with Pennsylvania in the region after the conflict. Fauquier's motivation remains unclear, but perhaps the colony found little of interest at Easton. Failure at Easton might ensure that a distracted Pennsylvania would leave the door more open for Virginian dominance in the Ohio River valley after the conflict.

Whatever influenced Virginia's curious diplomatic actions in 1758, some contemporaries suspected the scheming Ohio Company. Others chalked it up to Virginia's relative inexperience in treating with the particular native peoples involved in the events of $1758 .^{585}$ These sentiments perhaps explain why Forbes ultimately chose not to award management of the southern Indians to the one man who had thus far demonstrated the ability to handle them.

${ }^{583}$ Forbes to Fauquier, August 16, 1758 in ibid, I:60.

${ }^{584}$ Denny to Fauquier, August 30, 1758, Fauquier to Denny, September 11, 1758; Denny to Fauquier, November 22, 1758 in ibid, I:64, 70 \& 113.

${ }^{585}$ Boulware, Deconstructing the Cherokee Nation, 98. 
Colonel William Byrd, commander of the Second Virginia Regiment, had demonstrated success in recruiting and working with Cherokee war parties prior to and during the 1758 campaign and had already received notice and respect from Forbes. Sent with Peter Randolph to recruit the Cherokee in 1756 , the colonel had proven his adeptness in Indian affairs. In 1758, Byrd actively assisted in sorting through the confusing behavior of the Cherokee warriors as they acted as allies but at the same time engaged in hostilities with Virginian settlers. Throughout the summer, he provided Forbes with detailed intelligence about the actions of the Cherokee. He personally recruited a contingent of warriors, moreover, who remained among the most loyal allies in the British camp, and Bouquet and Forbes recognized this fact. ${ }^{586}$ For these actions, Forbes singled him out for particular praise. To Pitt, Forbes wrote:

He in the Month of February last offered his services to the Earl of Loudoun, and embarked at New York for South Carolina, went from thence some hundreds of Miles up into the Cherokees Country, assembled their Chiefs, and by a march of near a thousand Miles conducted some of the best warriors of that Nation through both the Carolina and Virginia into this Country ... This [the remaining Cherokee allies] is owing in a great degree to Mr. Byrd of Virginia to whom I should do a great injustice if I was silent upon the Occasion.-As he has a very large and opulent fortune in Virginia he joined the Earl of Loudoun early after his Arrival in America, Accompany'd the Army to Halifax last year, and sett a noble example to all the Gentlemen of the Continent, who had either Inclination or Abilities to serve the King and their Country. ${ }^{587}$

${ }^{586}$ Byrd to Forbes, June 30, 1758 in FP, GD 45/2/40-44, SNA; Byrd to Forbes, August 24, 1758 in FP, GD 45/2/53-67.

${ }^{587}$ Forbes to Pitt, July 10, 1758 in Stewart, Letters of Forbes, 25. 
At times, they did utilize Byrd's skills to reduce tensions, but stopped short of entrusting him with universal authority. ${ }^{588}$ "[I]f you think that Col. Burd [sic] can be of Service by his Influence with the Cherokees," Bouquet informed St. Clair, "I wish you coud prevail on him to come with them to Reas Town." ${ }^{589}$ The reluctance of Forbes to entrust him with the management in lieu of Byrd's previous success remains perplexing when viewed separately from the colonel's close connection to Virginia.

By August, Forbes did note in correspondence to Fauquier that even Byrd had lost influence over even his once loyal Cherokees. ${ }^{590}$ Perhaps the colonel's failure to retain his Cherokee recruits led Forbes to lose confidence in his abilities. Due to the general's earlier glowing endorsement of Byrd, however, it seems quite probable that something else must have convinced Forbes to ignore the colonel's merits and refuse to turn over the management of the southern Indians to him. Perhaps Glenn, suspecting Virginian intrigue in his declining influence, likewise desired to thwart Virginian influence among the Cherokee. Perhaps instead Pennsylvanian politicians, often accused by Virginians of seducing Forbes into building a road benefiting Pennsylvania at the expense of Virginia, played a role. While Pennsylvanians had less interest in Cherokee alliance than their southern counterparts, they certainly had the opportunity to influence the general while he maintained his headquarters in Philadelphia deep into the summer. Any attempt to marginalize Virginian power after the conflict remained a priority for the Pennsylvanians. Byrd, either through partisan whispers or some other perceived liability, thus proved inadequate.

The failure of Forbes to identify a clear figure with the authority to treat with the Cherokee left the relationship in disarray, and the Cherokee did little to improve the situation. Disgruntled with the handling of the campaign, lack of presents, and violence in Virginia, some began to issue not-so-subtle

15.

${ }^{588}$ For accounts of Byrd's abilities see Bouquet to Forbes, June 2, 1758 in Stevens, Papers of Bouquet, II:

${ }^{589}$ Bouquet to St. Clair June 3, 1758 in Stevens, ibid, II: 24.

${ }^{590}$ Forbes to Fauquier, August 16, 1758 in Reese, OPFF, I:59. 
threats. In one case, Cherokees declared they would "[r]ob all the English Houses they met with in their way home." ${ }^{591}$ Filtered back home by soldiers serving in the north, such reports would have done nothing but confirm the belief that Cherokees did intend to plunder the English

On June 16, with the alliance severely threatened, Bouquet convened a council of 224 Cherokees and Catawbas at Fort Loudon in Pennsylvania. In a feeble attempt to avert the Cherokee desertion, the colonel addressed and tried to solve many of the issues that threatened the alliance. He opened with an ideological plea, accusing the French of enslaving Indians and stealing land-a somewhat hypocritical charge that likely had little effect on the audience. He then turned to gifts, promising an abundance of presents at the conclusion of the campaign. Still a point of contention, Bouquet took a different tack, citing the inefficiency of carrying all the gifts to and from Fort Duquesne. He continued by acknowledging the slowness of his force, pleading patience on the part of the Cherokee. In exchange, he asked for Cherokee advice-undoubtedly an empty attempt at flattery. Finally, the colonel appealed to their manhood. Promising glory for those that stayed, he simultaneously projected femininity on those that had already left by derisively suggesting that they could not stand to be separated from their wives any longer. His speech had a marginal effect because by September the army retained only eighty allies. ${ }^{592}$

Thus, although Forbes clearly recognized the need to have one individual manage the campaign's Indian affairs, the general failed to settle on anybody. If his army's glacial movement cracked the Anglo-Cherokee alliance, and the issue of compensation exacerbated the problem, no one presented a coordinated plan to heal the wounds. Any of the options would have been better than the diplomacy-by-committee approach. Instead, too many people in too many places dealt inconsistently

${ }^{591}$ Ward, Breaking the Backcountry, 166.

${ }^{592}$ For Bouquet's speech see Speech to the Cherokee and Catawba Indians, June 16, 1758 in Steven, Papers of Bouquet, I: 98-101. The report of eighty remaining allies comes from Forbes to Pitt, September 6, 1758 in Kimball, Correspondence of William Pitt, I: 338. 
with the Cherokee. To make matters worse, in lieu of an adequate person to trust with universal management of the native allies, the British officers became increasingly involved. ${ }^{593}$ "I shall make it my Business, \& study," a captain in the Highland regiment wrote Forbes, "to communicate all the Intelligence of this kind [relating to the Indians] I can gather tho you may perhaps have a prior knowledge of them from those better acquainted." 594

The captain's uncertainty about his abilities reflects those shared by other officers. One complained about communication problems resulting from the lack of qualified interpreters. ${ }^{595}$ Other's lamented their general lack of knowledge, noting that "I am not familiar enough with their manners and customs." ${ }^{596}$ To be certain, British involvement in the management of the Cherokee had disastrous results. Due to the percolating hostilities between the Virginians and Cherokees, Fauquier begged "the Favour of you [Forbes] to let none return at the End of the campaign without proper Escorts." 597 In an attempt to assist Virginia, Forbes lectured the Cherokee on the behavior expected of them as they passed through Virginia and attempted, though usually unsuccessfully, to provided the requested escorts. ${ }^{598}$ This policy backfired on the British when Forbes made a serious blunder when he desired his officers "would deprive [Little Carpenter] of the use of arms and ammunition; and escort him from one place to another, to prevent his doing any mischief to the Inhabitants." ${ }^{599}$ While the general believed that the actions of the important Cherokee leader warranted such action, the perceived insult seriously damaged the Anglo-Cherokee relationship. ${ }^{600}$ The situation spiraled out of control and disgruntled Cherokee and jumpy colonists increasingly encountered each other in the Virginia backcountry.

\footnotetext{
${ }^{593}$ Fauquier to Washington, June 25, 1758 in Reese, OPFF, 1:42.

${ }^{594}$ Allan Maclean to Forbes, May 2, 1758 in FP, GD 45/2/37-39, SNA.

${ }^{595}$ Mercer to Bouquet, June 5, 1758 in Stevens, Papers of Bouquet, II:34.

${ }^{596}$ Bouquet to Forbes, June 16, 1758 in ibid, II:95-96.

${ }^{597}$ Fauquier to Forbes, July 20, 1758 in Reese, OPFF, I:52.

${ }^{598}$ Forbes to Fauquier, August 16, 1758 in ibid, I:59.

${ }^{599}$ Washington to Fauquier, November 28, 1758 in ibid, I:115-116.

${ }^{600}$ Forbes to Fauquier, November 26, 1758 in ibid, I:114.
} 
Too much had gone wrong. The endless frustrations of a slow-moving European army, lack of adequate presents, chaotic diplomatic mechanisms, and violence in the Virginia backcountry had taken their toll. To make matters worse, contact with Europeans had induced an outbreak of smallpox. ${ }^{601}$ If they had truly been innocent in the violence, Cherokee patience had worn thin and retaliation began. By 1759, open warfare erupted. For three years, between 1759 and 1761, a mostly inconclusive war raged between the British and the Cherokee. ${ }^{602}$

Despite the obvious explanations of Anglo-Cherokee hostility, something more nefarious may have been at work. It may not have been a conscious thought, but perhaps the British lost interest in continuing to work on maintaining their relationship with the Cherokee. As the negotiations proceeded at Easton in Pennsylvania, the presence of southern native allies became increasingly problematic. ${ }^{603}$ Perhaps recognizing the diplomatic difficulties arising from their presence, the Cherokee reached out to both the Delaware and Six Nations expressing their friendship. ${ }^{604}$ The eastern Delaware and Six Nations responded in kind, and evidence of collaboration in gathering intelligence between the Delaware and Cherokee does exist. ${ }^{605}$ These expressions of friendship, however, appear to be an exercise in rhetoric because the strain between the northern Indians and their southern counterparts became readily apparent.

The Six Nations informed the Cherokee that "[w]e applaud your zealous Inclinations of going out from hence to see where the Enemy lives ... We conceive you had better at this time suspend your Resolutions ... should any accident happen to You . . it might raise some Mistrusts \& Jealousies in your

${ }^{601}$ The smallpox outbreak is recounted in Bouquet to Forbes, June 14, 1758 and Bouquet to Forbes, June 16, 1758 in Stevens, Papers of Bouquet, I: 89 and 96.

${ }^{602}$ For details concerning the Anglo-Cherokee War see Oliphant, Peace and War, chapters 3 and 4; Hatley, Dividing Paths, chapters 9 and 10.

${ }^{603}$ See McConnell, Country Between, chapter 6; Merrell, Into the American Woods, chapter 7.

${ }^{604}$ Norris to Franklin, June 13, 1758 in INL, 1154, HSP; An Indian Council, July 21, 1758 in Knoblauch, Johnson Papers.

${ }^{605}$ Washington to Fauquier, September 2, 1758 in Reese, OPFF, I:66. 
Nation against us." ${ }^{606}$ While the rhetoric expressed concern for the well-being of the Cherokee, the statement suggests that the Six Nations did not wish to see the Cherokee operating within their sphere of influence. On at least one occasion, British officers became aware of a dispute between a Mohawk and Cherokee leader that appeared serious enough to request Johnson's arbitration. Teedyuscung's eastern Delaware, while generally reporting amiable relations with the Cherokee, informed Peters of negative interactions they had with members of the Catawba war parties. ${ }^{607}$

The Ohio Indians, who still officially fought alongside the French and consequently faced the brunt of southern natives' aggression, felt even more threatened by so many enemy Indians in their territory. While coaxing these hostiles to the Easton Treaty, Post became intimately aware of this sentiment. The Cherokee themselves proved cognizant of this fact, commissioning Post to treat with the Delaware on their behalf in June $1758 .^{608}$ After embarking on his primary mission, the missionary again encountered Delaware uneasiness. After giving speeches along the Ohio, a young warrior named Daniel verbally berated Post for the British "hire [of] one thousand two hundred Indians to kill us." ${ }^{609}$ Here, the panicked warrior could only have been referring to the southern Indians. Fortunately, cooler heads prevailed. In the village of Kuskuski, headmen expressed their desire for peace to Post. They had cause to be afraid, however, drawing the missionary a map showing the dangers that surrounded them. ${ }^{610}$ As Daniel's outburst and map show, the Cherokee represented at least a part of their concerns.

The French learned about Post's mission when several astonished soldiers encountered the lone "Englishman." Try as they might, the French could not pry the diplomat away from their erstwhile Indian allies. They did, however, attempt to use the Cherokee presence to prop up their crumbling

\footnotetext{
${ }^{606}$ An Indian Congress, July 24, 1758 in Knoblauch, Johnson Papers.

${ }^{607}$ Abercromby to Johnson, May 13, 1758 in ibid; Denny to Quakers, May 3, 1758 in FAM, AM.525, HSP.

${ }^{608}$ Two Journals of Western Tours in Twaites, Early Western Journals, 179.

${ }^{609}$ Ibid, 212.

${ }^{610}$ Ibid, 226-227.
} 
alliance. The outburst by Daniel, Post recorded, had been directly enticed by French influence. ${ }^{611}$ After the Seven Years' War concluded, moreover, Indians further to the west reported that the French "had spirited them up telling them the English were coming with a body of Southern Indians to take their Country from them and inslave them." ${ }^{612}$ What they saw develop in 1758 seemed to clearly confirm the French warning.

Forbes, meanwhile, knew well the efforts of Post on the Ohio. Pinning high hopes on the effort, he clearly recognized the effect the Cherokee had on his desired allies. "[A]Il the northern Indians," he reported to Pitt, "were kept in awe by the presence of so many Cherokees." ${ }^{1613}$ While he may have overstated the case, the essence rang true. Peace with the Ohio Indians hung in the balance, and the Cherokee inherently threatened it. In an effort to encourage the peace factions, the general unequivocally ordered his troops to steer clear of Indian villages. ${ }^{614}$

In light of these facts, Forbes's motivation comes into focus. He certainly recognized the advantages of an alliance with the Cherokee. Removed so far from their homes, and increasingly difficult to deal with, the Cherokee ultimately proved less important to Forbes's immediate goal of capturing Fort Duquesne than the neutrality or support of the northern Indians. Forbes never makes a direct statement, but as the Cherokee drifted away and peace with the Ohio Indians increasingly seemed a reality, the general's reliance on the Cherokee waned.

After 1758, as the French empire in North America crumbled and increasing numbers of natives treated with the British, the break with the Cherokee served an additional purpose. The outbreak of war in the south signaled, to some degree, the seriousness of British efforts to woo France's former allies in the Ohio Valley and Great Lakes. In 1761, Amherst wrote James Grant, then preparing to lead

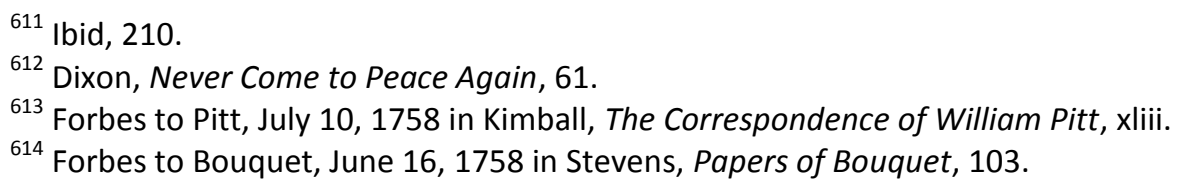


an expedition against the Cherokee, that they [western Indians] seem greatly pleased with the late change of affairs." ${ }^{\prime 15}$ At this point, some natives expressed their desire to join in the war effortsomething George Croghan had encouraged by 1760 among the Hurons, Ottawas, and Potawatomies. ${ }^{616}$ Some Chickasaws, Creeks, and Catawbas also came to side with the British against the Cherokee. ${ }^{617}$ While the Ohio Indians seem to have avoided the conflict, some historians do recognize the importance of the perception of an active alliance with the British. ${ }^{618}$ By 1760 , the commandant at Fort Pitt reported a brisk Indian trade and a strong relationship with the local peoples. Thus, the war between the southern colonies and the Cherokee that erupted after the Forbes Campaign helped unify Pennsylvanian and western Indians with the British interest because it provided them with a common enemy. ${ }^{619}$

While Britain's new friendship with France's old allies proved short-lived, as Pontiac's Uprising shattered the peace in 1763, the unifying factor of the Anglo-Cherokee War does appear to have played a significant role as France ceded power to Britain in most of eastern North America. While visible cracks had developed in the Anglo-Cherokee alliance due to military speed, gift-giving, and violence in Virginia, it likewise seems apparent that British hopes of winning over the Ohio Indians lessened their commitment to salvaging the relationship despite the interests of the individual colonies. As the British moved deeper and deeper into the country once called New France, friendship with local Indians proved more significant to British aims.

Forbes's decision to neglect relations with the Cherokee in favor of Pennsylvania's native neighbors might thus be seen as a response to his immediate military needs. It might also have been encouraged by interested parties from Pennsylvania. This decision, moreover, also contributed to the conflict that erupted between the Cherokee and southern colonies in subsequent years. Consequently,

\footnotetext{
${ }^{615}$ Amherst to Grant, February 27, 1761 in Mays, Amherst Papers, 202.

${ }^{616}$ Dixon, Never Come to Peace Again, 61.

${ }^{617}$ Amherst to Grant, July 10, 1761 in Mays, Amherst Papers, 278.

${ }^{618}$ See McConnell, Country Between, 153.

${ }^{619}$ Stanwix to Pitt, March 17, 1760 in Kimball, Correspondence of William Pitt, 265-266.
} 
a decision made by a British agent significantly affected the well-being of individual British North American colonies. Pennsylvania benefitted while Virginia and South Carolina suffered. The incredible impact that decisions made by British agents thus ensured that the separate colonies would vie for their favor in a similar fashion to the factions within Pennsylvania. 


\section{Chapter 6: British Agents and Colonial Competition}

Governor Lyttelton of South Carolina, referring to the tremendous sums of money the British government had resolved to spend to win the Seven Years' War, remarked to his Virginian counterpart on December 12, 1758 that "the Ministry have been under no Embarrassment in money matters." ${ }^{20}$ Until shortly before Lyttelton's pronouncement, very little success had resulted from these expenditures in North America. In large measure this resulted from the numerically superior British colonies failing to coordinate their efforts against their less numerous, but more coordinated, French Canadian adversaries. The lack of cohesion between the provinces reflected the independent nature of their settlement as well as the competitive nature with which each viewed the others. As diplomacy with the Southern Indians had demonstrated, provinces sought to carve out advantageous situations for themselves, sometimes at the expense of the others. The British commanders who arrived in the colonies to push forward the empire's conflict with France brought with them the ample funding referred to by Lyttelton, along with patronage networks that offered tremendous economic benefit to individuals in the colonies. Concurrently, they sparked increased competition for access to these advantages. The Royal authority possessed by these officers and the infrastructure left behind by their campaigns further attracted the attention of the colonies as they continued to dispute territorial boundaries with one another. Access to British agents thus became critical to colonies vying with each other for both immediate and future advantages in their ongoing competition.

The campaign organized by Forbes in 1758 promised to pour enormous sums of money and to create badly needed employment for whichever colony he interacted with most closely. The opportunities, moreover, affected all economic statuses from poor landless immigrants to wealthier merchants. All citizens, it seems, could reap the windfall of a strong military presence in their colony.

\footnotetext{
${ }^{620}$ Lyttelton to Faquier, December 12, 1758 in Reese, OPFF, I:132.
} 
For Pennsylvania, the arrival of the British military came at a critical time as the colony's economy had fallen on hard times by the mid-eighteenth century. As recently as 1727, workers in Pennsylvania's iron industry had successfully demanded higher wages, thus indicating that labor remained highly valued in the province. In the decades prior to the Revolution, however, opportunities began to decline. The Seven Years' War only exacerbated these problems. The economy sharply contracted in 1756 and 1757 as Indian raids diminished opportunities and production in Pennsylvania's hinterland. Land ownership remained the ideal for many Pennsylvanians, and some managed to acquire it. An influx of German migrants, however, resulted in increasingly stiff competition for cheap land just when raids had decreased the availability of western tracts. By 1759 , consequently, as many as fifty percent of the colony's inhabitants remained landless. The German migrants remained among the most destitute. Forced to pay as much as ten percent of their wealth to leave Germany, many quickly fell into debt in their new homeland. Forced to survive by means other than agriculture, many took up trades and actively engaged in Pennsylvania's local market economy. In this, they reflected the behavior of the province's Anglo population that had also become intricately connected to local markets. One company store alone purchased 118 locally-manufactured products. This focus on the local markets made Pennsylvanians ideally situated to take advantage of the myriad needs of Forbes's army in 1758 .

A shortage of currency had likewise threatened to hold Pennsylvania's economy from reaching its full potential. The proprietary faction's commitment to hard currency made it difficult for the colony's poor to fully participate in the economy, as they found it difficult to acquire the precious metal. The popular faction, as it so often did, opposed this commitment and instead promoted the issuance of paper money. Despite its continued unpopularity with many Pennsylvanians, the new currency issued beginning in the 1720 s drastically improved the economic situation of the poor, particularly the 
newcomers who faced the equally challenging task of finding credit in a land where they had few connections with established local people. ${ }^{621}$

The needs of Forbes's army thus materialized at Pennsylvania's time of greatest need and the province's residents actively sought to benefit from the opportunity. For the predominant agricultural population, the vast quantities of materials demanded by the British military provided a welcome outlet for grain surpluses. During the campaign, the British military procured thousands of bushels of wheat, "Indian corn," oats, and hay from Pennsylvania farmers. ${ }^{622}$ Beyond the vast quantities purchased, a British officer reported that a "[h]igh price is offered to get people to cheerfully respond." ${ }^{\prime \prime 23}$ This 'cheerful response' should not have been necessary because the British government had enacted an embargo on colonial shipping to both ensure necessary transport for troops and that necessary supplies remained in the colonies to support the armies. For those merchants unable to export agricultural products, and for the farmers who depended on the merchants to do so, the military's appetite for produce remained critical to economic solvency. ${ }^{624}$ The embargo, however, proved difficult to enforce, leading Governor Denny to ask Forbes "[i]f you could possibly spare me a greater force . . . it would be very agreeable for many reasons, particularly to enforce the embargo." ${ }^{625}$ For those able to divert vessels around the embargo, the higher prices offered by Forbes's contractors proved necessary because many continued their prodigious commerce with Great Britain's sugar-producing islands in the

621 Johnson, "Poor People," 118, 124 \& 126; Häberlein, “German Migrants," 560-562, 568-569 \& 573; Simler, "Tenancy in Colonial Pennsylvania," 550; James Clarke Moore Collection, 1408, HSP; Kennedy, "Cash for Turnips," 596-597 \& 599; Minutes of a Court of Enquiry, June 3, 1758 in FP, GD 45/2/53-67, SNA; Schweitzer, "Contracts and Custom," 464-465.

622 Bouquet to Forbes, June 7, 1758; Forbes to Bouquet, June 10, 1758 in Stevens, Papers of Bouquet, II: 47-48 \& 65; Burd to Edward Shippen, May 14, 1758 in Shippen Family Papers, Vol. H, Col. James Burd Letterbook, 595A, HSP; John Wright to St. Clair, April 16, 1758, Thomas Pratner to St. Clair, April 10, 1758; James Wright to St. Clair, April 15, 1758 in Forbes Papers, GD 45/2/22-31, SNA.

${ }^{623}$ Calculation of Expences for transporting provisions, Forbes Papers, GD 45/2/97, SNA.

${ }^{624}$ Samuel Fothergill to John Pemberton, April 22, 1758 in Pemberton Family, Pemberton-Fothergill Correspondence, 484A, Vol. 34, HSP; Richard Peters Account Books, July 1758 in James Clarke Moore Collection, 1408, HSP; John Collins to Clifford, October 17, 1758 in Pemberton Family/Clifford Correspondence, 484A, Vol. 2, HSP.

${ }^{625625}$ Denny to Forbes, July 13, 1758 in Forbes Papers, GD 45/2/53-67, SNA 
Caribbean. ${ }^{626}$ A merchant named Aaron Gaskill perhaps best demonstrated the extent to which

Pennsylvanians played these two markets against one another, noting that "people are trading abroad actively while Forbes struggles." ${ }^{627}$

Pennsylvania's agricultural community reaped additional rewards from the presence of Forbes's army. Despite its unpopularity, the military hired hundreds of wagons and horses for the campaign and in the process poured badly needed hard currency into the rural economy. ${ }^{628}$ In addition, the presence of military forces assisted the farmers in harvesting their crops without molestation from hostile forces. "It is General Forbes's orders," Shippen informed a garrison commander, "that you ... use your utmost Endeavours to Protect the Neighbouring Frontier Inhabitants from the enemy while employed in getting in their Harvest." ${ }^{629}$

While Pennsylvania benefitted significantly from the needs of the British military, other colonies attempted to gain access to the influx of capital. Virginia, for example, provided much of the livestock requisitioned by the army. ${ }^{630}$ In a letter to Governor Fauquier, Washington expressed his hopes that the campaign might assist Virginia. "I have ... wrote a circular Letter to the back inhabitants of Virginia," he related, "setting forth the great advantages of keeping that place [Fort Pitt] . . that they ... will be allowed good prices for such species of Provisions as they shall carry." ${ }^{631}$

${ }^{626}$ Isaac Cox to Clifford, October 15, 1758, Thomas Tipping to Thomas Clifford, November 9, 1758, Invoice of 50 Bls. of Flour shipped by William Vincent, November 23, 1758, Carter Stevens, Sm Simpson, Alex Millock, November 28, 1758; E. Williams to Clifford, November 28, 1758 in Pemberton Family/Clifford Correspondence, 484A, Vol. 2, HSP.

${ }^{627}$ Aaron Gaskill to Clifford, March 19, 1758 in ibid.

${ }^{628}$ St. Clair to Forbes, December 7, 1758 in Forbes Papers, GD 45/2/22-31, SNA; Samuel Nelson to Forbes, February 9, 1759 in Forbes Papers, GD 45/2/33-36, SNA; J. Napier to Forbes, April 30, 1758 in Forbes Papers, GD 45/2/37-39, SNA; Myajor Orndt to Captain Nelson, October 6, 1758; Denny to Nelson, October 7, 1758 in Forbes Papers, GD 45/2/53-67, SNA; His Excellency General Forbes in Forbes Papers, GD 45/2/68-81, SNA; Bouquet to Forbes, June 11, 1758 in Stevens, Papers of Bouquet, II:74.

${ }^{629}$ Shippen to Captain Adam Reed, July 9, 1758 in Shippen Family Papers, Small Volumes, Box 1-7, 595A, HSP.

${ }^{630}$ A Return of Provisions at Pittsburgh, January 1, 1759 in Forbes Papers, GD 45/2/37-39, SNA; Ourry to Halkett, January 15, 1759 in Forbes Papers, GD 45/2/40-44, SNA.

${ }^{631}$ Washington to Fauquier, December 2, 1758 in Reese, OPFF, I:117. 
Beyond increasing the demand for agricultural products, the military required tremendous amounts of hardware to advance its agenda. The soldiers themselves required a variety of goods, including kettles, blankets, tents, whiskey, rum, shoes, excess leather to repair the shoes with, powder horns, shot pouches and uniforms. With a more refined taste, the officers requested things such as distinguished uniforms, paper, and pens. General needs for the army included scythes, axes, halters, curry-combs, bells, hobbles, horseshoes and nails for the cavalry units. ${ }^{632}$

The increased desire for these everyday items increased demand in the colony, raising prices and at the same time increasing the job opportunities for Pennsylvanian craftsmen. While many of these craftsmen toiled in shops in the eastern part of the colony to produce hardware to be shipped westward, the army recruited many others to join the campaign and manufacture the needed supplies on the spot. Tailors, saddlers, gunsmiths, wheelwrights, blacksmiths, workmen, carpenters, masons, shipbuilders, bricklayers, and painters all followed the army to find lucrative work during the expedition. Along with these craftsmen, the general hired an abundance of surgeons, messengers, and guides. Many officers additionally acquired servants to attend them. ${ }^{63}$

Beyond the attendant craftsmen, Forbes's army depended upon a combination of contractors and independent merchants to procure the many items necessary to the campaign's continued progress. The military relied heavily upon large, well-connected merchant firms to provide much of the

${ }^{632}$ Bouquet to Joseph Shippen, June 9, 1758, St. Clair to Bouquet, June 9, 1758, Bouquet to Forbes, June 11, 1758, Bouquet: Memoranda, June 12, 1758; Washington: Memoranda, June 13, 1758 in Stevens, Papers of Bouquet, II: 58, 61, 74-75, 80 \& 83; Shippen, June 3, 1758 in Shippen Family Papers, Small Vols., Box 1-7, 595A, HSP; Burd to Sam Allen, April 26, 1758, Burd to William Henry, May 3, 1758; Burd to Hughs, May 20, 1758 in Shippen Family Papers, Vol. H-James Burd Letterbook, 595A, HSP; Forbes to Conrad Snider, June 27, 1758; Armstrong to Forbes, July 2, 1758 in Forbes Papers, GD 45/2/68-87, SNA.

${ }^{633}$ Bouquet to Allen, November 25, 1758 in Stewart, Papers of Forbes, 68; Bouquet to Forbes, June 7, 1758, Forbes to Bouquet, June 10 1758; Bouquet to Forbes, June 11, 1758 in Stevens, Papers of Bouquet, II:51, 65 \& 73-74; Armstrong to Forbes, Forbes Papers, GD 45/2/68-87, SNA; Thomas Barren to Forbes, January 8, 1759 in Forbes Papers, GD 45/2/97, SNA; John Jones Jr. Daybook, AM.485(40), 1193, HSP; Gerard G. Beekman to Clifford, February 26, 1759 in Pemberton Family/Clifford Correspondence, 484A, Vol. 2, HSP; Mary Pemberton to Israel Pemberton, December 25, 1758 in Pemberton Family Papers, Vol. 12, 484A, HSP; Fauquier to Lyttelton, October 5, 1758; Fauquier to William Prentice, July 27, 1758; Fauquier to Washington, October 7, 1758 in Reese, OPFF, I:84 \& 87. 
material needed for its operations. Smaller independent merchants, however, catered to the day-to-day needs of the soldiers. ${ }^{634}$

The soldiers themselves thus had become an incredible source of revenue for the citizens of whichever colony they occupied. Although it did not always happen as planned, Forbes attempted to pay his men on a weekly basis. Each company received on average nearly $£ 2500$ a year in pay collectively to be spent in the communities they passed or with the merchants who followed the army. Many independent citizens secured a tidy fortune by serving as recruiters, earning more than three pounds per man enlisted in either the provincial ranks or Royal American Regiment. While certain regions remained resistant to providing manpower for the campaign, others provided abundant volunteers who received a hefty bounty upon enlistment which might be sent home to enter the local economy or be spent on the campaign and enter the broader provincial economy. For many of these green recruits, service provided a critical means to support their families. Many of the impoverished German immigrants enlisted and at least one man wrote personally to Forbes expressing his gratitude for providing him the means to feed a family recently dispossessed of their land. ${ }^{635}$ For some of these men, the campaign presented the additional opportunity of getting a fresh start along the Ohio River after the conclusion of the campaign. Some discharged men, one officer informed Forbes, "wou'd

${ }^{634}$ For a discussion of a large firm, see Stern, David Franks. For the independent merchants, see Forbes to Bouquet, June 10, 1758 in Stevens, Papers of Bouquet, II:65; James Kenny to Israel Pemberton, April 3, 1759 in Pemberton Family Papers, Vol. 12, 484A, HSP; Dagworthy to Forbes, November 6, 1758 in Forbes Papers, GD 45/2/33-36, SNA; A Return of Provisions in Store belonging to the Contractors at the Sundry Posts \& Forts on the Route towards fort Duquesne, August 23, 1758 in Forbes Papers, GD 45/2/37-39, SNA; Denny to Forbes, July 8, 1758 in Forbes Papers, GD 45/2/53-67, SNA; Joseph Shippen to Edward Shippen, July 12, 1758 in Shippen Family Papers, Vol. K-J. Shippen Military Letterbook, 595A, HSP; Burd to peter Stukee, June 12, 1758 in Shippen Family Papers, Vol. H-Col. James Burd Letterbook, 595A, HSP.

${ }^{635}$ Extract of a Private Letter, March 19, 1755 in PRNA, Vol. 2, 33029, BL; Burd to Lloyd, June 7, 1758 in Shippen Family Papers, Vol. H-Col. James Burd Letterbook, 595A, HSP; John Forbes Adjutent General Loudoun's Recruiting Instructions for North America, November 16, 1757 in Forbes Papers, GD 45/2/18-21, SNA; Benzel to Forbes, January 27, 1758, Fletcher to Forbes, February 2, 1758; Fletcher to Forbes, February 6, 1758 in Forbes Papers, GD 45/2/32/40A-76, SNA; Calculation of the Pay \& James Campbell to Forbes, GD 45/2/33-36, SNA. For a detailed examination of the economic status of the Pennsylvanian recruits, see Stephenson, "Pennsylvania Provincial Soldiers;" Mathew C. Ward, "An Army of Servants: The Pennsylvania Regiment During the Seven Years' War," The Pennsy/vania Magazine of History and Biography, Vol. 119, No. 1/2 (January-April 1995). 
choose to remain in this Country [Pittsburgh]; as they think they have a better prospect of a Livelyhood." ${ }^{636}$

Those that chose to return eastward in the winter of $1758-1759$ with the victorious general needed winter quarters and the necessities to support them through the harsh season, providing the residents of their barrack towns with yet another opportunity to reap an economic windfall. The general located seven hundred troops in Philadelphia, four hundred in Lancaster, two hundred in Reading, three hundred in Germantown, and one hundred in Chester for a total of seventeen hundred troops. The quartered soldiers required not only the rented buildings acting as barracks but innumerable items to support them through the winter including food, wood, candles, blankets and window panes. The officers themselves rented out rooms in private dwellings and requested additional, more refined, items to keep them comfortable. ${ }^{637}$ While the needs of the enlisted men and officers inevitably continued the flow of currency into the communities in which they wintered, some Pennsylvanian citizens took greater advantage of the situation. In a letter to Forbes, a Philadelphian reported that he was unable:

[t]o believe the Damage sustain'd [to the rented barracks] may not be equal to the Complaint [by the landlords], nor am I convinced, what is complain'd of has been done by the soldiers, quarter'd in the Barracks, as there are numbers of disorderly houses, in that neighbourhood, kept by people who give encouragement at ill hours, to the

${ }^{636}$ Major Henry Fletcher to Forbes, January 22, 1758 in Forbes Papers, GD 45/2/32/40A-76, SNA.

${ }^{637}$ Forbes to Denny, November 26, 1758 in Stewart, Forbes Papers, 70; Arthur Morris to Forbes, November 14, 1758 in Forbes Papers, GD 45/2/18-21, SNA; Distribution of Quarters of Colonel Montgomerys Regt, January 8, 1759; The forces with general Forbes are recommended to be Quartered as follows, ND, in Forbes Papers, GD 45/2/33-36, SNA; John Inglis to Francis Halkett, January 13, 1759; Halkett to Forbes, January 13, 1759 in Forbes Papers, GD 45/2/40-44, SNA; Thomas Barrow to Forbes, January 13, 1759 in Forbes Papers, GD 45/2/97, SNA. 
Vagabonds of this place, who are very numerous; \& frequently escape Censure, by the blame being laid on the soldier, when not guilty. ${ }^{638}$

If accurate, this report indicates that at least some Pennsylvanians erroneously reported abuses against property not perpetrated by the soldiers in an attempt to further profit from their presence.

Besides the direct economic benefits of association with the British military, many colonists continued to find advantage by tapping into the patronage networks of the officers. At least two Pennsylvanians, John Anthony and Mr. Christopher, utilized intermediaries to seek commissions from Forbes and his superiors in the British, rather than provincial service. Achieving status as a British officer ensured them a half-pay pension at the conclusion of the conflict if the army did not retain their services. Not to be outdone, Virginians scrambled to ensure the favor of the British officers as well. One Virginian successfully petitioned Forbes to recommend him to head Britain's North American Navy Office and another asked the general to represent his case for a pension. ${ }^{639}$ In 1755, Washington "had the compliment of several blank Ensignicies given him to dispose of to the Young Gentlemen of his [acquaintance]." ${ }^{640}$ This authority, given him by Braddock, not only ensured that several Virginians received royal commissions and the resultant benefits but it also increased Washington's personal network of clients in the province. Byrd, moreover, thanked Forbes for "your intended Letter to General Amherst [the new commander-in-chief] in my Favour." ${ }^{641}$ The ambitious Virginian colonels combined their efforts when requesting a back-dated royal commission for the Virginia regiment's brigade major. This request appears to be an indirect attack on Pennsylvania's counterpart. Joseph Shippen had the ear

${ }^{638}$ Morris to Forbes, ND in Forbes Papers, GD 45/2/18-21, SNA.

${ }^{639}$ Arthur Morris to Forbes, March 13, 1758, Arthur Morris to Forbes, April 3, 1758; Arthur Miller to Forbes in Forbes Papers, GD 45/2/18-21, SNA; Memorial to Gen Abercrombie about the officers of the 17, ND in Forbes Papers, GD 45/2/37-39, SNA; Sir Joshua Narreck to Newcastle, October 28, 1757 in NP, 32875, BL; James Abercromby to Fauquier, October 5, 1758, Warrant for James Robert, October 27, 1758; Fauquier to Amherst, March 11, 1759 in Reese, OPFF, I:183; Fred Anderson, ed. George Washington Remembers: Reflections on the French \& Indian War (New York: Rowman \& Littlefield Publishers, Inc., 2004), 22.

640 lbid, 18.

${ }^{641}$ Byrd to Forbes, January 21, 1759 in Forbes Papers, GD 45/2/53-67, SNA. 
of Forbes because the general operated exclusively within Pennsylvania. By dating the Virginian brigade major's commission earlier than that of Shippen, however, the colonels made their man superior in rank to Shippen as policy dictated that length of service established superior authority when officers shared the same rank. Governor Fauquier attempted to assist Washington and Byrd's attempts to ensure favor for Virginia by reaching out to Amherst upon his promotion to commander-in-chief and inviting Forbes to winter in Williamsburg rather than Philadelphia in the winter of $1758-1759$ as he intended to do. ${ }^{642}$

The attempts by Virginia to undermine the status of Shippen and diminish Pennsylvania's access to Forbes by inviting him to winter in Williamsburg demonstrates the extent to which the colonies vied with one another for access to sources of British authority. This maneuvering resulted from the presence of competing interests between the provinces. Much of the competition did result from the economic interests of each colony. John Robinson of Virginia expressed his expectation that a "great Benefit will accrue to our Colony" as a result of the presence of Forbes's army. ${ }^{643}$ This expectation, shared by each of the colonies individually, went far beyond the incidental economic benefit the military provided private citizens because the colonies vied with each other for broader assistance directly from the British government. Virginia, for example, actively attempted to convince British authorities to reimburse them for the costs of arming and provisioning their provincial troops. Maryland trumped its neighbors by absolutely refusing to pay anything for its troops and forcing Forbes to assume the costs or risk losing the Maryland contingent entirely.

The vast sums of money appropriated for North America by Parliament became even more contentious. Mindful of its distance from North America and lack of clarity on the specific contribution of each colony, Parliament issued lump sums to be divided between the colonies. Virginia, North Carolina and South Carolina, for example, received a lump sum of fifty thousand pounds to be divided

${ }^{642}$ Washington to Fauquier, September 2, 1758, Forbes to Fauquier, November 5, 1758; Fauquier to Amherst, March 11, 1759 in Reese, OPFF, I:67, 83, \& 103.

${ }^{643}$ John Robinson to Forbes, April 10, 1758 in Forbes Papers, GD 45/2/45-52, SNA. 
between them by the commander-in-chief. These lump sums triggered the ever-present competitive nature of the colonies leading each to plead its case against the others. Virginia, for example, cited the unrest with the Cherokee and attendant costs along with its involvement in the conflict from the outset to stake its claim for the lion's share. Similar competition in New England prompted Massachusetts to employ an agent in London to represent its claims on a similar lump sum. The colonies additionally attempted to protect their own commerce at the expense of the others. At least Virginia and North Carolina petitioned the admiralty to base squadrons along their coasts to protect against enemy privateers. $^{644}$

Beyond the economic competition, many of the colonies possessed serious disputes with one another about territorial boundaries. Pennsylvania disputed borders with both Connecticut and Maryland, but since Forbes found the resolution of these disputes irrelevant to the success of his campaign, the disagreement between Pennsylvania and Virginia about the upper Ohio River valley became a critical issue during the campaign. ${ }^{645}$

Both colonies claimed the region surrounding Forbes's intended target. Citing difficulty in recruiting Virginians to serve in the upper Ohio River valley in 1754, Governor Dinwiddie of Virginia had expressed his desire for "an order for running the Line between the Two Provinces." ${ }^{646}$ With the issue

${ }^{644}$ Ministry [Duke of Newcastle, Earl of Holdernesse et al] [upon hearing of events on the Ohio], June 26, 1758; The Memorial of William Boltan Esqr., Agent for his Majesty's Province of the Massachusetts Bay in New England, 1757 in PRNA, Vol. 2, 33029, BL; Sharpe to St. Clair, June 3, 1758 in Forbes Papers, GD 45/2/22-31, SNA; Dobbs to Forbes, December 22, 1758 in Forbes Papers, GD 45/2/53-67, SNA; De Lancy to Forbes, July 11, 1758 in Forbes Papers, GD 45/2/97, SNA; Forbes to Bouquet, June 10, 1758 in Stevens, Papers of Bouquet, II:65; Enclosure: James Abercromby to Major General James Abercromby, March 12, 1758, Fauquier to St. Clair, June 6, 1758, Fauquier to Gen. Abercromby, June 10, 1758, Washington to Fauquier, June 19, 1758, Washington to Fauquier, July 10,1758 , Fauquier to Washington, July 20, 1758, Fauquier to Cleveland, August 25, 1758, Fauquier to Admiralty, August 25, 1758, Fauquier to Washington, September 16, 1758, Fauquier to Lyttelton, October 13, 1758, James Abercromby to Fauquier, November, 17, 1758, Fauquier to Forbes, November 19, 1758, Fauquier to Loudoun, November 20, 1758; Pitt to Fauquier, December 9, 1758 in Reese, OPFF, I:6, 15, 21, 36, 50, 53, 62-63, 72, 89, 106, $108-111 \& 129$.

${ }^{645}$ Extracts of sundry Letters from Thomas Penn to John Hunt being their answers to his Letters to them at Bristol, October 23, 1760 in Cox-Parrish-Wharton Papers, Series 4, Box 14, Folder 15, 154, HSP.

${ }^{646}$ Abstract of a Letter from the Govr. Dinwiddie, March 12, 1754 in PRNA, Vol. 2, 33029, BL. 
still unresolved in 1758, it became apparent to interested parties in both Pennsylvania and Virginia that the infrastructure laid by Forbes's advance might provide one of the colonies with far greater access to the region after the campaign, thus giving it an advantage in securing the region through commerce and the spread of its population. The geography, and, it might be said, the interested parties, offered Forbes with two possible routes. The first option suggested a drive northwards from Virginia as Braddock had done in 1755 using Fort Cumberland in western Maryland as a base of operations. This route offered the distinct advantage, Virginians argued, of utilizing the pre-existing Braddock Road carved with such difficulty during the ill-fated expedition. Braddock's road presented challenges as well. It required the passage of two major waterways, the Youghiogheney and Monongahela Rivers, and required a much farther route for Pennsylvanian grain shipments to reach the army. Some observers additionally noted that three years of new growth would make the route even more difficult to clear a second time. The second option suggested a movement directly west from the population centers of Pennsylvania to strike Fort Duquesne from the east rather than south. This route provided the advantage of travelling a shorter distance from the grain-producing farmlands of eastern Pennsylvania and the lack of major waterways beyond the Susquehanna that would need to be crossed by the army. The small settlement at Raystown (modern-day Bedford) might serve as a base of operations on par with Fort Cumberland. This choice, however, presented its own difficulties. While eastern Pennsylvania boasted an excellent infrastructure for the time, travel beyond the Susquehanna River became more challenging. Ancient Indian paths crisscrossed the land, but no clear road had been built to Raystown. Beyond the small settlement, a series of high ridges necessitated detailed knowledge of the landscape and few Pennsylvanians possessed this in $1758 .^{647}$

${ }^{647}$ John Florin, The Advance of Frontier Settlement in Pennsylvania, 1638-1850: A Geographic Interpretation (University Park, PA: Department of Geography, The Pennsylvania State University, 1977); Paul A.W. Wallace, Indian Paths of Pennsylvania (Harrisburg, PA: Pennsylvania Historic and Museum Commission, 1965). 
Forbes exacerbated the ensuing debate by hedging his bet throughout most of the campaign and keeping the option of using either route open. From Pennsylvania, the general resolved to cut the road at least as far as Raystown which sat almost directly north of Fort Cumberland. In the meantime, he left Washington in command of mostly Virginian troops in the south with orders to both clear the old Braddock Road several miles to the northwest while simultaneously cutting a road towards Raystown. Forbes had developed an idea whereas he could advance the army at least as far as Raystown and then evaluate the prospect of cutting the road directly west. If it proved impractical, he could then divert the army south to Fort Cumberland and then proceed northwestward along the old Braddock Road.

Although Maryland had no claims to the region, Forbes instructed the colony to improve two roads, one between Fort Frederic in central Maryland to Fort Cumberland and the other from William's Ferry on the Potomac River to Lancaster, to facilitate either decision. ${ }^{648}$ The implications of Forbes's impending decision could not have been more stark-either Pennsylvania or Virginia would have a clear road leading into the contested upper Ohio River Valley at the conclusion of a successful campaign. ${ }^{649}$

Virginian leaders, spearheaded by an uncharacteristically dramatic Washington, immediately campaigned for the old Braddock Road. On August 5, 1758, Washington informed Faquier that "a fatal Resolution takes place of opening a New Road from Rays Town to Fort Duquesne." ${ }^{\text {"50 }}$ This "fatal resolution" did not occur without a determined effort by the Virginians to dissuade the general from such a decision. "I don't doubt," Fauquier had written Byrd, "that Coll. Washington and your self will do all in your power to set this [the advantage of taking the old Braddock Road] in its true light to your

${ }^{648}$ Forbes to Denny, March 20, 1758 in Stewart, Forbes Papers, 8; Bouquet to Sharpe, June 13, 1758; Bouquet to Forbes, June 16, 1758 in Stevens, Bouquet Papers, II:82 \& 97; Sharpe to Fauquier, July 12, 1758 in Reese, OPFF, I:52.

${ }^{649}$ For a discussion of the choice of a road, see Charles Morse Stotz, "Forbes Conquers the Wilderness: A Modern Odyssey". The Western Pennsylvania Historical Magazine. Vol. 67, No. 4 (October, 1984): 316.

${ }^{650}$ Washington to Fauquier, August 5, 1758 in Reese, OPFF, I:57. 
Commanding Officers." ${ }^{\prime 651}$ Towards that end, Washington met routinely with Bouquet and Forbes throughout the summer and early fall to present Virginia's case presenting a series of arguments that he found quite obvious. ${ }^{652}$ Washington opened by extolling the quality of the Braddock Road, noting that "there is already a good Road made a Road universally confess to be the best that either is, or can be found anywhere." ${ }^{163}$ The colonel logically followed with negative comments about the Pennsylvania route, referring to it as "worse than any other upon the Continent" and "undescribably bad." ${ }^{654}$ Against claims that the Pennsylvania road might be improved, the colonel chose to stress the lateness of the campaign season. ${ }^{655}$ When Forbes ultimately made the decision to drive west from Raystown rather than divert to the south, Washington dramatically insisted that the campaign had been lost, lamenting "[w]hat a Golden opportunity have we lost!"656 To highlight the dangers of choosing the more timeconsuming route, the colonel reminded his superior about the disaffection of the Cherokee. "I then exprest my apprehensions of the Southern Indians," he related to Fauquier, "in case of a miscarriage." 657 If logic proved insufficient, the Virginians intended to levy vague threats about their continued support for Britain's military endeavors. Reporting back to Fauquier, Washington recalled:

In the conference I had with Colo. Bouquet ... I did among other things to avert the resolve of opening a new Road, represent the great Expence the Colony of Virginia had been at to support the war, the Charge of raising a $2 \mathrm{~d}$ Regiment at such short a Notice; the time limited for the Service of it; and the Cruelty therefore of risking the Success of

${ }^{651}$ Fauquier to Byrd, August 17, 1758 in ibid, I:61.

${ }^{652}$ Washington to Fauquier, June 17, 1758; Washington to Fauquier, August 5, 1758; Washington to Fauquier September 2, 1758 in ibid, I:30, 55 \& 66.

${ }^{653}$ Washington to Fauquier, August 5, 1758 in ibid, l:58.

${ }^{654}$ Washington to Fauquier, September 2, 1758; Washington to Fauquier, October 30, 1758 in ibid, I:66 \& 96.

${ }^{655}$ Byrd to Fauquier, August 3, 1758, Washington to Fauquier, August 5, 1758, Washington to Fauquier, September 2, 1758, Washington to Fauquier, September 25, 1758; Washington to Fauquier, September 28, 1758 in ibid, I:57-58, 65, 68, 80 \& 82.

${ }^{656}$ Washington to Fauquier, September 2, 1758 in ibid, I:66.

${ }^{657}$ Washington to Fauquier, September 2, 1758 in ibid, I:66-67. 
an Expedition upon such precarious Measures when so much depended on it; and our inability to do more. ${ }^{658}$

In this instance, Washington's use of the word "inability" might more accurately be replaced with the word "refusal," because just over two weeks prior to his statement Fauquier had informed Byrd to "join with him [Washington] in representing the Case of the Virginia Regiments, and the Temper of the Assembly ... God only knows whether they may be prevail'd on to do as much the next year." ${ }^{659}$ Thus, the leaders of Virginia sought to make it clear to Forbes that their continued support might just hinge on the choice of the route. In an attempt to influence the general, the Virginians went above his head and communicated their dissatisfaction to authorities in Britain. Fauquier, in a surreptitious manner, attacked the choice of road while again indicating that Virginia might not be counted on for support in the future. To the Board of Trade, he wrote that "[t]his Inactivity as it is here call'd, and the long Delay before they set forward, has raised a Doubt whether the Attack can be attempted this year which has so much soured some of the Members of the Assembly that they are unwilling to grant any more Money towards carrying on the Expedition." 660

The province additionally sought to recruit supporters within the British military establishment to bolster their logic and threats. Several British officers unconnected to Virginia advised Forbes to adopt the old Braddock Road. The general's direct superior, James Abercromby, issued a set of recommendations, not orders, to Forbes in March 1758. He included among them the use of Braddock's Road, although he resided distantly at New York and could not accurately provide any specific directions and likely recommended the route only because of its familiarity to the British military establishment. Perhaps more importantly, a young engineer in the Royal American Regiment named Harry Gordon likewise recommended the Braddock Road. While charged with overseeing the construction of

\footnotetext{
${ }^{658}$ Washington to Fauquier, September 2, 1758 in ibid, I:66.

${ }^{659}$ Fauquier to Byrd, August 17, 1758 in ibid, I:61.

${ }^{660}$ Fauquier to Board of Trade, September 23, 1758 in ibid, I:76.
} 
fortifications, the officer had also been dispatched to reconnoiter the best possible direction to conduct the campaign. Having evaluated both options, Gordon proved much better informed than Abercromby to make a recommendation. Beyond all other officers, Sir John St. Clair, Forbes's quarter-master general, embraced the view of Virginia. He had, however, spent most of the early campaign in northern Virginia and Forbes and Bouquet generally disregarded his comments assuming that he had been induced to make them by interested Virginians. ${ }^{661}$ The Virginians rejected such a sentiment, expressing their belief that their recommendations resulted not from bias but a legitimate interest in the success of British arms despite which colony it might benefit. In defending his assessment of the roads, Washington informed Fauquier that "you may depend the statement is true, free from exagerations, and flowing from a Mind deeply affected at the prospect before us." ${ }^{662}$

Just as Forbes and Bouquet assumed that St. Clair had been influenced by Virginians, the Virginians assumed that they had been unduly convinced about the practicability of a western road by Pennsylvanians. ${ }^{663}$ Washington reported to Fauquier that:

$[T]$ he Pensylvanians whose Interest present and future it was to conduct the Expedition thro' their Government, and along that way, because it secures their Frontiers at present, and the Trade hereafter, a Chain of Forts being Erected, had prejudic'd the General absolutely against this Road; made him believe we were the partial people and determin'd him at all Events to pursue that Rout so that their sentiments are already fully known on this matter, and to them as Instigators, may be attributed the great misfortune of this miscarriage. ${ }^{664}$

661 Instructions for the Ohio, March 28, 1758 in Forbes Papers, GD 45/2/45-52; Remarks concerning an Enterprise to recover the Ohio, ND in Forbes Papers, GD 45/2/68-81; St. Clair to Bouquet, June 9, 1758; St. Clair to Bouquet, June 11, 1758 in Stevens, Papers of Bouquet, II:60 \& 76-77.

662 Washington to Fauquier, August 5, 1758 in Reese, OPFF, I:58.

663 Ibid; Washington to Fauquier, September 28, 1758 in ibid, I:82.

${ }^{664}$ Washington to Fauquier, September 2, 1758 in ibid, I:67. 
Perhaps this belief of Washington explains the disparity of his memories of Braddock and Forbes. While he fondly reminisced about Braddock and famously retained the sash that Braddock wore upon his death, Washington barely noted Forbes in his memoirs. ${ }^{665}$ To Fauquier, the colonel sardonically noted that "[t]he General [Forbes] I dare say, from his good Character, can account fully and no doubt satisfactorily for these delays." ${ }^{\prime 666}$

While the Virginians, and Washington in particular, might have treated Forbes a bit harshly for his decision, there appears little doubt that the Pennsylvanians surrounding the general did attempt to convince him to abandon the old Braddock Road as an option. Despite the absence of a Pennsylvanian correspondent as active as Washington, Burd noted as much, reporting that "cutting the roads from our Province to the ohio, which seems to sitt heavy on the minds of our southering Neighbours, and they don't quite Excuse me for this Event." ${ }^{667}$ Forbes and Bouquet, however, consistently maintained that they made their decision as a result of the interests of the service, not provincial concerns. In the privacy of their personal correspondence, Forbes indicated to Bouquet that :

$[T]$ hose two gentlemen [Washington and Byrd] were the only people that I had met with who had shewed their weakness in their attachment to the province they belong to, by declaring so publickly in favour of one road without their knowing anything of the other, having never heard from any Pennsylvania person one word about the road. ${ }^{668}$

At the same time, despite this insistence on arriving at his decision independently, Forbes indicated some degree of Pennsylvanian influence to Bouquet. "As to the roads," he wrote, "I can say nothing, only I was advised by every one to go By Raes town." ${ }^{\text {669 }}$ If the majority of the advice received from

${ }^{665}$ See Anderson, George Washington Remembers.

${ }^{666}$ Washington to Fauquier, September 2, 1p758 in Reese, OPFF, I:68.

${ }^{667}$ Burd to Allen, August 18, 1758 in Shippen Family Papers, Vol. H-Col. James Burd Letterbooks, 595A, HSP.

${ }^{668}$ Forbes to Bouquet, September 23, 1758 in Stewart, Papers of Forbes, II:52.

${ }^{669}$ Forbes to Bouquet, June 16, 1758 in Stevens, Papers of Bouquet, II:103. 
British military officers and Virginians recommended the old Braddock Road, the "every one" referred to by Forbes must have been Pennsylvanians who did a better job of masking their interest than the Virginians had.

As he had so often done with local disputes in Pennsylvania, however, the general sincerely lamented the competing interests of the various colonies with which he had to cooperate with. The consistency in which he disregarded individual interest in those cases certainly suggests that when it came to the decision of the route, despite the likely presence of Pennsylvanian encouragement alongside that of Virginia, the general chose the path he felt most beneficial to British aims as a whole. Forbes certainly became jaded by the consistent prodding of the Virginians. ${ }^{670 ~ " T h e ~ r o a d ~ f o r w a r d ~ t o ~ t h e ~}$ Ohio must be reconnoitered again in order to be sure of our further progress," he wrote upon arriving in Raystown, "for it would grieve me sadly that Mr. Washington or Mr. Byrd should have any reason to find fault with that, which without their knowledge they have so publickly exclaimed against." ${ }^{671}$

At the same time, Forbes came to find fault with the Pennsylvanians who had almost certainly promoted their own designs. "No reliance can be made in the reports of the people who claim to know the country, after passing Raystown," Bouquet informed Forbes, "[a]ll whom I have questioned contradict each other, and we shall only learn the truth about it by exploring the country ourselves." ${ }^{672}$ As he had so often done in other instances, the general came to rely more on handling things himself than trusting in local colonists to assist him. Forbes consequently dispatched his own scouting parties to evaluate the routes and subsequently determined upon the Pennsylvania route. ${ }^{673}$ In justifying his final decision to the Virginians, Forbes told Bouquet that "I told them plainly that, whatever they thought, yet I did aver that, in our prosecuting the present road, we had proceeded from the best intelligence that

\footnotetext{
${ }^{670}$ Forbes to Bouquet, September 23, 1758 in Stewart, Papers of Forbes, 52.

671 Ibid, 53.

${ }^{672}$ Bouquet to Forbes, June 11, 1758 in Stevens, Papers of Bouquet, II:74.

673 Ibid, 73; Route from Yorktown to Conogocheek, ND; Report of the Country between Pittsburgh and the
} great Meadows, ND in Forbes Papers, GD 45/2/68-81, SNA. 
could be got for the good and convenience of the army, without any views to oblige any one province or another." ${ }^{674}$ The general repeated these sentiments when describing his decision-making to Secretary of State Pitt. ${ }^{675}$ For his part, Bouquet, who knew the travails with which Forbes had to deal with better than any man, noted that "the success of this expedition is entirely due to the general, who, by ... not yielding to the urging instances for taking Braddock's road, which would have been our destruction." ${ }^{676}$ Forbes's decision to scout on his own to determine his course of action reflected his deep disappointment in the general lack of adequate assistance from the colonies during the campaign and their refusal to work together. Fauquier identified the problem best, informing Forbes that " $[\mathrm{t}]$ hese Delays have given some Disgust, and make the Gentlemen of the Colony cautious how they engage in any Expence which is not properly their own, and applicable to their own Colony only." ${ }^{677}$ With this "provincial" attitude, the colonies squabbled amongst themselves about how the campaign should be conducted and which responsibilities fell to which colony. Fort Cumberland, for example, existed within the boundaries of Maryland but more directly protected settlements in Virginia. Maryland thus argued that Virginia should be responsible for its maintenance. A similar situation occurred in Raystown, where the army constructed Fort Bedford. When Forbes commanded the Virginian troops to march to its garrison, Virginians complained that the fort protected Pennsylvania only. Supplies became a contentious issue as well, as each colony sought to ensure that its contributions served to supply its troops and not another province. In one instance, Virginian troops, devoid of blankets, requisitioned a supply intended for British troops. To ensure that the other colonies did not take offense, Forbes found himself compelled to require the colony to replace the blankets with a later shipment. On another

${ }^{674}$ Forbes to Bouquet, September 23, 1758 in Stewart, Papers of Forbes, 52.

${ }^{675}$ Forbes to Pitt, July 10, 1758; Forbes to Pitt, September 6, 1758 in ibid, 25 \& 31; Bouquet to Forbes, June 14, 1758 in Stevens, Papers of Bouquet, II:87; Washington to Fauquier, September 2, 1758 in Reese, OPFF, I:67.

\footnotetext{
${ }^{676}$ Bouquet to Allen, November 25, 1758 in Stewart, Papers of Forbes, 69.

${ }^{677}$ Fauquier to Forbes, November 19, 1758 in Reese, OPFF, I:108.
} 
occasion, unarmed Virginian troops took possession of Maryland arms at Fort Cumberland but made sure to later to return them. ${ }^{678}$ Pennsylvanians, moreover, sought assurances that the arms they supplied would be used to "furnish their own Troops." 679 The massive amount of materials being sent by four different colonies to support its own soldiers created a logistical nightmare for the British officers overseeing the campaign. ${ }^{680}$ John Armstrong accurately identified the indecision confronting many officers, reporting that "any thing hitherto Sent, has not been particularly enough directed either for what Use, to whome to be deliver'd, or at what place, by which means, to gether with the intermixture of the Virginia Stores I'm doubtful of mistakes." ${ }^{\prime 61}$

The provincial attitude towards sharing military material cut against the grain of what Forbes and his officers expected of what they assumed to be mutually supportive subjects of the same British government. They should not have been surprised at the situation in which they found themselves. In a 1754 assessment of the state of Britain's North American colonies, one government official noted that "the said Colonies being in a divided disunited state, there has never been any joint Exertion of their Force or Councils to repel or defeat the Measures of the French, and particular Colonies are unable and unwilling to maintain the Cause of the whole." ${ }^{682}$ Virginia knew this reality all too well, having been the most aggressive of all the colonies leading up to the Seven Years' War. "[H]ow easily might all these Evils [French encroachment] been remedied," one Virginian lamented, "had our neighbours done their Duty in sending their assistance." ${ }^{\prime 63}$ Lord Halifax in the Board of Trade had attempted to remedy this problem in 1754 by proposing a greater organization of the North American provinces, and the colonists

${ }^{678}$ St. Clair to Washington, June 13, 1758, Washington to Fauquier, September 2, 1758, Washington to Fauquier, September 25, 1758; Fauquier to Washington, October 7, 1758 in Reese, OPFF, I:32, 67, 80 \& 87; Washington: Memoranda, June 13, 1758 in Stevens, Papers of Bouquet, II:83.

${ }^{679}$ Forbes Memoranda, June 1, 1758 in ibid, II:1.

680 James Abercromby to Fauquier, November 17, 1758 in Reese, OPFF, I:106.

681 John Armstrong to Bouquet, June 12, 1758 in Stevens, Papers of Bouquet, II:81.

${ }^{682}$ Representation of the State of the Colonies in North America, 1754 in PRNA, Vol. 2, 33029, BL.

${ }^{683}$ Extract of a Letter, July 23, 1754 in ibid. 
themselves attempted to achieve the same ends to no avail at the Albany Congress. Conflicting interests simply ran too deeply. The governors, for their part, generally attempted to work together because their interests typically remained more closely connected to broader imperial interests, but they too often found themselves limited by the more locally-oriented assemblies and councils. ${ }^{684}$

The leaders of the colonies, hoping for personal gain, simply trusted one another too little. ${ }^{685}$ Washington perhaps most clearly voiced this mistrust, advising Fauquier that "to prevent this advantageous commerce from suffering in its infancy by the sinister views of designing, selfish men; of the different Provinces, I humbly conceive it absolutely necessary, that Commissioners from each of the colonies be appointed, to regulate the mode of that Trade, and fix it on such a basis that, all the attempts of one Colony undermining another, and thereby weakening and diminishing the general system, might be frustrated." ${ }^{686}$ This competition and mistrust resulted in a situation where the individual colonies attempted to promote their contributions and denigrate those of their neighbors to encourage increased imperial support.

Due to the potential benefits of imperial favor, the colonies went to great lengths to make themselves appear particularly attentive to the needs of the empire despite their very apparent individual motives. After his successful conquest of Fort Duquesne in November of 1758, Forbes voiced his understanding of the critical role the colonies played in exploiting the victory. "It is now the time to take vigorous measures to secure this conquest," he declared, "and unless Virginia and Pennsylvania can agree upon an immediate assistance, all our pains and advantages will be lost.." ${ }^{687}$ Abercromby had earlier made it clear what might result from the lack of adequate and coordinated support from the

${ }^{684}$ Lord Halifax, August 15, 1754; Heads of General Shirley's Dispatches, April 19, 1755 in ibid; Fauquier to Sharpe, June 18, 1758, Sharpe to Fauquier, July 3, 1758; Forbes to Fauquier, August 16, 1758 in Reese, OPFF, I:33 \& 60.

${ }^{685}$ Washington to Fauquier, November 28, 1758; Washington to Fauquier, December 2, 1758 in ibid, I:115 $\& 117$.

${ }^{686}$ Washington to Fauquier, December 2, 1758 in ibid, I:118

${ }^{687}$ Forbes to Allan, November 25, 1758 in Stewart, Letters of Forbes, 68. 
colonies. "Let me therefore intreat you to awaken them [Assembymen] out of their Error," he wrote, "of which I should be very Sorry for I shall find my self obliged to represent their conduct to the King." ${ }^{688}$ While some benefits resulted from association with the British military, the general's warning indicated that dire consequences might result from failure to adequately support it. To avoid these consequences, the individual colonies scrambled to portray themselves in the best possible light.

Virginia most actively extolled the lengths to which it had sacrificed its interests in the advancing British interests. Towards that end, leaders of the colony made certain to remind British authorities of their initial enthusiasm for the campaign, the vast number of troops they had risen to support it, and the tremendous costs the colony had incurred to support them. Thy further attempted to bolster their image by reminding these authorities of the crisis brewing with the Cherokee and the augmented difficulties this placed the province in. Virginia additionally highlighted its magnanimous acquiescence to Forbes's ultimate selection of the Pennsylvanian road over the old Braddock route. Finally, Virginians emphasized the superior role their troops played in an engagement between French and British forces outside Fort Duquesne in September of $1758 .{ }^{689}$

That month, a Highland officer, Major James Grant, convinced Colonel Bouquet to grant him command of a sizeable force of British, Pennsylvanian, and Virginia troops to conduct a reconnaissancein-force towards Fort Duquesne as the entire army inched slowly towards its objective. Likely looking for personal glory - this is the same man who seventeen years later requested only five thousand men from the Ministry with which he intended to subdue the rebellious colonies-Grant hoped to surprise the French garrison and end the campaign in one swift stroke. Without Forbes's consent, Bouquet

${ }^{688}$ Abercrombie to Sharpe, April 14, 1758 in Forbes Papers, GD 45/2/68-87, SNA.

${ }^{689} A$ Return of the $2^{\text {nd }}$ Virginia Regimt., June 12, 1758; Proposal to demand 100 more VA's to relieve regulars in Forbes Papers, 45/2/33-36, SNA; Washington to Fauquier, August 5, 1758, Washington to Fauquier, September 2, 1758, Fauquier to Washington, September 16, 1758, Fauquier to Washington, November 4, 1758, Washington to Fauquier, November 5, 1758, Fauquier to Forbes, November 19, 1758; Fauquier to Washington, November 22, 1758 in Reese, OPFF, I:57-58, 68, 72, 99-100, 104,107-109 \& 113. 
consented. Through a serious of very poor decisions, the march of Grant's troops resulted in disaster with hundreds of the force killed or captured. From captivity, both Grant and Major Andrew Lewis-the commander of the Virginian contingent-embarked on a public relations campaign to affix blame to anybody other than themselves. Lewis's arguments proved, not surprisingly, entirely convincing to the other Virginian officers. ${ }^{690}$ "The troops were divided, which caused the Front to give way, and put the whole into confusion," Washington reported, "except the Virginians, commanded by Captn. Bullett, who were (in the hands of Providence!) a means of preventing all of our People from sharing one common fate." ${ }^{\prime 691}$ According to this convenient narrative, the Virginians stood firm as chaos swirled around them. As the British and Pennsylvanian troops fled the battlefield in a cowardly fashion, they thus secured the escape of at least some of the force. While detailed analysis of the battle does not necessarily contradict the role the Virginians played, Fauquier continued to send British officers accounts of the battle as late as March of 1759, Virginian attempts to exploit their role demonstrates the lengths to which some colonies went to promote the extent to which they successfully assisted British aims in the Seven Years' War. ${ }^{692}$

While less active than the Virginians, Pennsylvanians did not fail to trumpet their contributions as well. Similar to its southern neighbor, the colony took pride in reminding British officials of its own troop contributions. In the spring of 1758 , Pennsylvanian leaders congratulated one another that they had raised one thousand soldiers rather than the eight hundred requested of it. During the winter of 1758-1759, it garrisoned five hundred troops to the one hundred of Virginia to protect Britain's new acquisitions. ${ }^{693}$

${ }^{690}$ Washington to Fauquier, September 25, 1758, Washington to Fauquier, September 28, 1758; Fauquier to Washington, October 7, 1758 in ibid, I:79, $82 \& 87$.

${ }^{691}$ Washington to Fauquier, September 28, 1758 in ibid, I:82.

692 Fauquier to Amherst, March 11, 1759 in ibid, I:184.

693 Disposition of Troops for the defence of the following Posts, ND, Return of the $2^{\text {nd }}$ Battalion of the Pennsylvania Regiment, December 25, 1758; A Daily Return of a Detachment of the Pensylvania Regiment, January 210 
Even South Carolina, one of the few colonies that did not supply troops to directly assist the British cause, attempted to defend its position. In the spring of 1758 , Governor Lyttelton made sure to inform Forbes that the colony attempted to augment its provincial military by two hundred men. He continued, however, to point out that the colony remained thinly inhabited and all troops raised needed to be retained for defense. The province had, he pointed out, endeavored to establish an effective embargo to supply ships and had actively engaged in diplomacy with the Cherokee in an effort to assist the cause..$^{694}$

While establishing positive appearances became imperative for the individual colonies, they also began to compare themselves, in a positive light, to other colonies while highlighting the failures of those provinces. Massachusetts, for example, made a point early in the conflict to point out the difficulties it operated under while at the same time noting the economic benefits the war provided the southern colonies. "We think it proper to observe to you that no Expedition can be carried on by this Province," Massachusetts claimed, "but what must subject it to greater Inconveniences and Charges than it would the southern Governments, for we being no provision Country, it is they that receive a benefit by the rise of Provisions, which such Expeditions always occasion, and our Cash must be remitted unto them for all we have Occasion for." ${ }^{695}$ In January 1759, moreover, Abercromby recorded a comment made by Byrd, in which he stated that he hoped Virginia's contribution had proved "sufficient to convince the World of our alacrity and chearfulness in exerting ourselves to the utmost of our Power for his Majestys Honor and the safety and welfare of our Country, tho' I am sensible we have been too often represented in a very different Light." ${ }^{\prime 696}$

9, 1759 in Forbes Papers, GD 45/2/33-36; Norris to Franklin in Norris Family Papers, 454, HSP; Norris to Franklin, April 29, 1758 in INL, 1154, HSP.

${ }^{694}$ Lyttelton to Forbes, April 26, 1758 in Forbes Papers, 45/2/37-39, SNA.

${ }^{695}$ A Representation of the Case of his Majesty's Province of Massachusetts Bay, September 26, 1755 in PRNA, Vol. 2, 33029, BL.

${ }^{696}$ Abercromby to Forbes, January 16, 1759 in Forbes Papers, GD 45/2/37-39, SNA. 
The Virginians defended themselves vigilantly and made certain to detract from the efforts made by its neighbors. The colony most significantly derided its neighbors for failing to come to its assistance during the early years of conflict before sizeable British forces and funding had arrived in North America. ${ }^{697}$ Towards that end, Governor Dinwiddie derisively remarked that "Pensylvania \& Maryland will do nothing which is a great Discouragement." ${ }^{1698}$ Pennsylvania refused to be portrayed as a disinterested party, and conversely denigrated the efforts of Virginia. ${ }^{699}$ Speaker of the Assembly Norris informed an English correspondent that the Board of Trade should be made aware that: our Colony, notwithstanding all the Difficulties we have been obliged to encounter with is now in a better state of Defence (the additional strength of the Kings Forces excepted) than any Colony in N. America . . . Look round the Colonies and compare this Barrier with Virginia Maryland or the Eastern colonies and the falsehoods of the Petitions agt This Province will be effectually confronted by Facts known to every Inhabitant among us. $^{700}$

While the Pennsylvania/Virginia rivalry continued, both provinces found a much easier time attacking the refusal of Maryland to provide nearly anything for the mutual British military effort. Maryland possessed no territorial claims in present-day western Pennsylvanian as its neighbors did, and thus proved less interested in participating in Forbes' campaign. ${ }^{701}$ Such inactivity, gleefully highlighted by both Pennsylvania and Virginia, prompted Bouquet to note that “I Expect nothing from Such People."702

${ }^{697}$ Washington to Fauquier, November 28, 1758 in Reese, OPFF, I:116; Lt. Govr. Dinwiddie, April 26, 1754; Extract from the Virginia Gazette, July 19, 1754 in PRNA, Vol. 2, 33029, BL.

${ }^{698}$ Virginia Lt. Govr. Dinwiddie, August 7, 1754 in ibid.

${ }^{699}$ Petition of the whole Burd [third] Battalion, July 4, 1758 in Forbes Papers, GD 45/2/33-36, SNA.

${ }^{700}$ Norris to Charles, May 26, 1756 in INL, 1154, HSP.

${ }^{701}$ A Return of the Maryland Forces at Fort Cumberland, January 9, 1759 in Forbes Papers, GD 45/2/3336; Fauquier to Board of Trade, June 28, 1758; Forbes to Fauquier, October 22, 1758 in Reese, OPFF, I:45 \& 94.

${ }^{702}$ Bouquet to St. Clair, June 3, 1758 in Stevens, Papers of Bouquet, II:24. 
The scramble by the various colonies to demonstrate their sacrifice for the cause while simultaneously minimizing the contributions of their neighbors reflects their realizations about the expectations held by British authorities. Early in 1754, British planners had proposed a plan to build a series of fortifications in the interior of North America to secure the region before the French could do so. ${ }^{703}$ At various places and at a variety of times during the Seven Years' War, the individual colonies embraced this concept and constructed their own fortifications. More than perhaps any other British endeavor in the conflict, the Forbes Expedition left in its wake a series of fortifications well beyond the Appalachian Mountains. They expected, however, strong colonial support to maintain these posts. ${ }^{704}$ "The succors and directions from England," Forbes wrote a Pennsylvanian, "would be too late, and if the colonies do not exert themselves to the utmost of their power, I am afraid they will have occasion to repent it." ${ }^{705}$ Due to their claims on the recently acquired upper Ohio River Valley, Pennsylvania and Virginia became the focus of most of the British demands for continued support.

The general demanded from Virginia the organization of cavalry and light units. Those, along with the regular provincial units, were to draw supplies and pay not from the British funds controlled by Forbes but instead from the colony itself. At the end of the campaign, moreover, the general insisted that Virginia leave him with two hundred troops to garrison the new posts. ${ }^{706}$ Because he faced difficulty on this last issue, largely due to the colony's resentment of the abandonment of the old Braddock Road, Forbes found himself forced to sardonically tell the governor that "I am so far embarked

\footnotetext{
${ }^{703}$ Proposal for building forts \&r, upon the Ohio, \& other Rivers in North America, April 3, 1754 in PRNA,
} Vol. 2, BL.

${ }^{704}$ Instructions for the Ohio, March 28, 1758 in Forbes Papers, GD 45/2/45-52, SNA; Forbes to Pitt, July 10, 1758; Bouquet to William Allan, November 25, 1758 in Stewart, Papers of Forbes, 26 \& 68-69.

${ }^{705}$ Forbes to Allan, November 25, 1758 in ibid, 68.

${ }^{706}$ St. Clair to Washington, June 13, 1758, Forbes to Fauquier, October 1, 1758, Forbes to Fauquier, November 5, 1758; Forbes to Fauquier, November 25, 1758 in Reese, OPFF, I:32, 83, 101-102 \& 114. 
I must see the end of the Campaign. So hope you will think it necessary that I ought to have some troops along with me and consequently send your orders accordingly." 707

More galling to the Virginians than the general's request that they maintain the pay of troops defending posts that they believed more directly benefitted Pennsylvania, he asked them in late November to begin to secure the old Braddock Road. ${ }^{708}$ Forbes's request made military sense but served to further aggravate the Virginians. The second road opened up an additional supply-line to the upper Ohio River Valley, thus stabilizing the British conquest. Now that the pressures of the campaign had subsided, moreover, adequate time existed to build roads. Despite the fact that the second route evened the score between Pennsylvania and Virginia and ensured that both had access to the region, Virginians resented the order. If their route been adopted in the first place as they had so actively argued for, the task would have already been accomplished. It also would have left Pennsylvania without easy access to the region ensuring Virginian dominance. Confronted by Virginian intransigence, Forbes reminded them of their duty, stating:

I shall not here enter into any discussion about the Assembly's having complyed with every thing that was demanded of them by Mr. Pitt's letter, nor shall I medle with the Government's not being able to perform ther promises in furnishing the Virginians with Arms, Tents, Blanketts \&ca but I beg leave to observe that if the Colony were so good as readily to make up the defficiencies in the Governments promise it never could have entered my thoughts that they would have made the smallest hesitation. ${ }^{709}$

Although Virginia received such a censure from the general for the reluctance of its support, Pennsylvania did not avoid similar demands.

\footnotetext{
${ }^{707}$ Forbes to Fauquier, November 5, 1758 in ibid, I:103.

${ }^{708}$ Forbes to Fauquier, November 26, 1758 in ibid, I:114.

${ }^{709}$ Forbes to Fauquier, November 5, 1758 in ibid, l:101-102.
} 
Besides the similar expectations for supporting its troops, Forbes expected Pennsylvania to finance the conference at Easton. He also expected that the colony would provide troops to garrison the posts he had constructed. As he had with the Virginia route, the general expected Pennsylvania to maintain and improve the road he had constructed with so much effort. ${ }^{710}$ If the province expressed any reluctance to provide this support, he informed them that "it will be a most monsterous reflection upon them if they do, and they never after can either look for, or expect the favour or protection of Great Brittain." ${ }^{711}$

Despite the claims made by the various colonies about the extent of their commitment, the efforts disappointed the British officers. A 1755 report, for example, detailed the extent of smuggling the colonies engaged in. This led British authorities to conclude that "these People [the French] in their marches to Destroy one English Province, are actually supported by the Bread raised in another." ${ }^{712}$ This level of avariciousness, combined with the apparent reluctance to support each other or pay due regard to British interests, led Forbes to declare that "[t]he whole Country . . . are a sett of helpless heartless mortalls." ${ }^{713}$ The competitiveness of the colonies and their general refusal to assist one another did consequently lead the British to pay attention to the degree to which each province contributed. Highranking officials in Britain, including Newcastle, recorded the troop returns of each individual province and the officers in North America consistently compared the helpfulness of the various colonies. ${ }^{714}$

If these tallies influenced British behavior towards the colonies, it occurred well after the fact because as they had so often done in other matters, the British officers remained focused on accomplishing the task at hand by any means necessary. The example of Maryland demonstrates this

${ }^{710}$ Forbes to Denny, October 16, 1758; Forbes to Denny, November 26, 1758 in Stewart, Papers of Forbes, $57 \& 70$.

${ }^{711}$ Forbes to Peters, August 28, 1758 in ibid, 31.

712 Extract of a Letter from New England, 1755 in PRNA, Vol. 2, 33029, BL.

713 Forbes to Peters, August 28, 1758 in Stewart, Papers of Forbes, 31.

${ }^{714}$ Fox to Holdernesse, March 28, 1756 in Holdernesse Papers, E6, BL; Bouquet to St. Clair, June 3, 1758 in Stevens, Papers of Bouquet, II:22. 
commitment. While Forbes made extensive demands from Pennsylvania and Virginia, Maryland had abjectly refused to provide much for his campaign. As a consequence, its provincial troops prepared to disband at the very moment that Forbes needed them the most. Consequently, Forbes opted to absorb the costs of supplying and paying the Maryland troops to prevent their loss, despite the howls of protest from Pennsylvania and Virginia. Unconcerned with treating each colony equally, the general adopted his consistent stance of subordinating provincial interest in favor of that of Britain. ${ }^{715}$

British engagement of deep-seated provincial jealousies thus played out in a similar fashion to Pennsylvania's internal politics and native diplomacy. Placating the colonies might be tolerated as far as possible, but in the end his conquest of the upper Ohio River Valley remained paramount. British, not colonial, interests prevailed. For provinces with a serious interest in how the post-war landscape developed, this mentality proved a great disappointment.

${ }^{715}$ Abercrombie to Sharpe, April 14, 1758 in Forbes Papers, GD 45/2/68-87, SNA; Forbes to Fauquier, November 5, 1758 in Reese, OPFF, I:102. 


\section{Conclusion}

In 1761, Lord Bedford wrote to the Duke of Newcastle that "I don't know whether the neighborhood of the French to our Norther[n] American colonies, was not the greatest security of their dependence on their Mother Country, who I fear will be slighted by them when their apprehensions of the French are removed." ${ }^{716}$ James Smith, former Pennsylvanian soldier and captive of native peoples, seemingly legitimized Bedford's fears by noting that "[h]ad the British king attempted to enslave us before Braddock's war, in all probability he might readily have done it, because ... we were unacquainted with any kind of war: but after fighting such a subtile and barbarous enemy as the Indians, we were not terrified at the approach of British red-coats." ${ }^{\prime 17}$ While Smith's comments fit nicely with the traditional narrative of the collapse of Anglo-American relations in the 1760 s and 1770 s, it must be remembered that he issued his comment decades after the Seven Years' War in the post-Revolutionary War era. Smith's sentiments thus benefitted from hindsight and were colored by developments during the War for Independence.

While Smith's assessment is clearly skewed by the passage of time, it remains evident that the Seven Years' War did alter Pennsylvania, but not necessarily in the militaristic fashion envisioned by Smith. Instead, the presence of Forbes' Army stimulated the colony's economy. Where local production failed to meet British demand, individuals built industries to meet the army's needs. Wheelwright shops, blacksmith shops, and mills all sprang up in Pennsylvania. Encouraged by British capital, they of course remained when military forces departed in the 1760s. The colony's infrastructure benefited as well. The British upgraded and built new ferries and boats, and paid to have road supervisors improve the existing roads in the eastern part of the state. The Forbes Road, stretching across the Appalachian

\footnotetext{
${ }^{716}$ Lord Bedford to Lord Newcastle, 9 May 1761, quoted in Knollenberg, Origins of the American Revolution, $\mathrm{xxx}$.

${ }^{717}$ Archibald Loudon ed., Loudon's Indian Narratives (Lewisburg: PA: Wennawoods Publishing, 1996), 247. 217
} 
Mountains, probably represented the most significant physical improvement of the Forbes Campaign.

For its time, the road seems to have become highly efficient. Shortly after the war, James Kenny reported that the trip between Bedford and Pittsburgh, a distance of around one hundred miles, could be made in twenty-five hours. ${ }^{718}$ The road, then, allowed Pennsylvanians to become less rigidly connected to Philadelphia and the Atlantic world and truly exploit the west by making the region more accessible to colonists. By 1772, when David McClure traveled through Carlisle, he found it "a considerable place of trade, principally with the western country \& the Indians." ${ }^{719}$ Problems did, however, exist. Hard currency remained scarce, causing some merchants great anxiety. Daniel Roberdeau, merchant and future Revolutionary War general, feared imprisonment for his inability to satisfy creditors with hard currency. ${ }^{720}$ The so-called Pontiac's Uprising of 1763 , moreover, once again challenged the colony. As Indian raiders descended upon the colony's borderlands, the western trade upon which towns like Carlisle had begun to depend collapsed. Hope for continued prosperity remained, however, as Englishman William Strahan noted to his Philadelphia trading partner. "[Y]our Province in general must thrive prodigiously," he noted, "after these disturbances are composed."721 As military forces diminished after 1758, Pennsylvania's agricultural, industrial, and mercantile activities remained strong due to the capital invested in the colony by individuals and British military forces. ${ }^{722}$

${ }^{718}$ Pennsylvania's economic success is discussed in Ward, Breaking the Backcountry, 73-74 \& 189 and John Gibson to Edward Shippen, 7 July 1758, Shippen Papers. Investment in Pennsylvania and infrastructure improvements are referenced in Louis Ourry to Henry Bouquet, 24 May 1759, in Stevens, Papers of Bouquet, III:90; David Jameson to James Burd, 12 April 1758, Shippen Papers; and "Journal of James Kenny" in Harpster, Crossroads, 94.

${ }^{719}$ Dexter, Diary of David McClure, 36.

${ }^{720}$ Daniel Roberdeau to Meyler Hall, 9 November 1765, Roberdeau Buchanan Collection, The Historical Society of Pennsylvania, Philadelphia. The future Revolutionary War general here expresses his concern about a possible prison sentence for not being able to pay his bills in hard currency.

${ }^{721}$ William Strahan to David Hall, 7 April 1765, William Strahan letters to David Hall, Historical Society of Pennsylvania, Philadelphia.

${ }^{722}$ For a detailed description of Pennsylvania's economy in the interwar period, see Lawrence Henry Gipson, The Coming of the Revolution: 1763-1775 (New York: Harper Torchbooks, 1954), 7 \& 13. 
Despite the economic prosperity, the British presence did not bring stability to the colony. The political squabbles between different factions, for example, worsened in the years following Forbes' death. The disenchantment with Pennsylvania's provincial government that emerged prior to and during the Seven Years' War continued after it. Opposition to Pennsylvania's government took on a more decidedly regional character after the conflict. Pennsylvania in the late 1750 s and through the 1760s can be broken down into roughly three distinct zones of habitation. Its political center was urban Philadelphia. Surrounding the city, Bucks, Chester, and York counties represented rural communities. They remained connected to the capital due to close proximity, but were also buffered from outside attacks by the colony's outlying settlements. These regions, typically considered 'frontier' territories (or perhaps more appropriately 'borderland' territories), proved the most exposed to Pennsylvania's enemies. The 'frontier' of Pennsylvania included Berks, Cumberland, Lancaster, Northampton, Northumberland, and later Bedford and Westmoreland counties. Although these areas had thus far trusted the Assembly to represent its interests accurately, distance alone precluded the citizens of these counties from having direct access to political power. The established order of the Pennsylvania Assembly further ensured this misrepresentation of demographic political power. While the three rural counties and Philadelphia provided twenty-six representatives, the five frontier counties provided only ten. ${ }^{723}$ Violence on the frontier during the Seven Years' War, and the apparent inability or reluctance of appropriate government entities to curb it, led many to question their support for such an agreement.

As the conflict between the old, now questionable, popular faction continued with the proprietary faction, Benjamin Franklin ultimately received a commission from the popular faction to take the case directly to British officials in London. There, without permission to do so, Franklin began proposing a removal of the Penns in favor of direct Royal control. Franklin's proposal won him few

\footnotetext{
${ }^{723}$ For a discussion of Pennsylvania's localism, see Knouff, Soldiers' Revolution, xvii. For a distribution of seats to the Pennsylvania Assembly, see Dixon, Never Come to Peace, 250.
} 
friends, either in London or in Philadelphia, but the Penns ultimately conceded to popular pressure. ${ }^{724}$ By 1764, "[t]he Gov[ernor] . . pass[ed] an Act Equally to tax the Prop. Estates as those of others, [which was] so long contended against." ${ }^{725}$ The opposing parties had agreed to tax the improved estates of the proprietors but not the unimproved wilderness lands, thus greatly diminishing the overwhelming financial burden contained in earlier proposals. The details of the arrangement, however, continued to fester. As late as 1767, William Strahan noted, "the Disputes between the Proprietors and the People.. . are likely to be agitated for a long while to come.."726 Strahan's assessment proved correct, but he and others failed to recognize the growing discontent of Pennsylvania's borderland communities.

In 1764, once again under Indian attack during Pontiac's uprising, Pennsylvanians in the frontier communities lashed out at easterners' apparent disregard for their safety. A collection of men ultimately called the Paxton Boys took matters into their own hands, swooping into Conestoga Manor to murder six peaceful Indians. They followed this atrocity by descending upon Lancaster, breaking into the jailhouse where survivors of the earlier attack had sought refuge, and executed fourteen more. ${ }^{727}$ The agitators then turned their attention to Philadelphia, which sheltered yet more Indian refugees, because "the people in and around Philadelphia lived at their ease and in plenty, and had no idea of the distress and trouble of the poor frontiers, and the want of protection and many other evils." ${ }^{128}$ The threat to Philadelphia created great consternation within the city.

Overnight, the proprietary and anti-proprietary factions dropped their quarrels and forged a temporary alliance. "The Governor," as a representative of the proprietors, "offered a reward of 200

724 Isaacson, Benjamin Franklin, 193.

725 John Ross to [?], 30 October 1764, Colonial-Revolutionary Period Manuscripts, Historical Society of Pennsylvania, Philadelphia.

${ }^{726}$ William Strahan to David Hall, 11 April 1767, William Strahan Letters to David Hall.

${ }^{727}$ Accounts of the incidents are recorded in Armand Francis Lucier ed., Pontiac's Conspiracy \& Other Indian Affairs: Notices Abstracted from Colonial Newspapers, 1763-1765 (Bowie, MD: Heritage Books, 2000$), 140$. For a detailed relation of the events, see Dixon, Never Come to Peace, 247-250.

${ }^{728}$ A Declaration and Remonstrance Of the distressed and bleeding Frontier inhabitants Of the Province of Pennsylvania, February 1764, in John R. Dunbar ed., The Paxton Papers (The Hague, Netherlands: Martinus Nijhoff, 1957), 101. 
Pounds for securing and prosecuting to conviction any three of the ringleaders in this inhuman \& bloody affair." ${ }^{729}$ On the other end of the spectrum, the anti-proprietary proponent Benjamin Franklin organized Associators because the Militia Act had previously expired. Ultimately, the regional factions resolved the impasse by agreeing to hear the grievances of the Paxton Boys. The backcountry participants in the massacre asked for all Indians to be removed from the settlements, public assistance for wounded citizens, a suspension of the Indian trade until all captives had been repatriated, stronger defensive measures and greater representation in the Pennsylvania Assembly. ${ }^{730}$ It also demonstrated that provincial political disputes had not dissipated by the end of the Seven Years' War. Surprising as it was, the popular and proprietary factions had united in their opposition to the western threat. They did so, however, only because the westerners threatened the established order in which both entities possessed a significant amount of authority. While the proprietary party might generally be assumed to have cared little for the welfare of the westerners, the popular faction had long represented their interests and reaped the political windfalls from doing so.

The maneuvers of the Paxton Boys thus overturned the longstanding agreement between underrepresented westerners and the generally responsive Pennsylvania Assembly. When viewed from the perspective of the westerners, dissatisfaction can be understood. One settler made his plight poignantly clear, writing:

"We are in the greatest Distress here. Besides the Danger we are exposed to, and the Shortness of our Crops, we are now full of People, who have been obliged to leave their Plantations, to avoid falling into the Hands of the Savages. Poor as we are, we can rescue a little Part of our poor Stock to our Fellow Subjects, who are reduced to begging

${ }^{729}$ Lucier, Pontiac's Conspiracy, 138.

${ }^{730}$ For a discussion of Philadalphia's reaction to the Paxton Boys, see Dixon, Never Come to Peace and Newland, The Pennsylvania Militia. The list of grievances is contained in A Declaration of Remonstrance in Dunbar, The Paxton Papers, 105-110. 
their Bread. Last Friday the Indians killed three Men in the Gap of the Mountain; and we have certain Accounts that there is a large Body, who, we expect, will fall upon this Settlement. This Day we have an Account that 3 or 4 Persons have been killed by the Savages near the Line. We donto know what to do; hard to give up our Livings, and yet, unless we are assisted, that will be the best we are to expect. The people about ten or twelve Miles beyond us have left their Plantations upon this Alarm. JOSEPH MAYHEW."731

The popular faction had attempted to assist those in dire situations by attempting to raise the funds necessary to raise an adequate provincial military capable of not only assisting the British war effort but protecting the settlements as well. They had, throughout most of the period, been blocked by the ever present gubernatorial veto protecting the proprietary estates from taxes. Settlers subjected to intense violence from French-allied Indians might be excused for failing to acknowledge this political reality and consequently placing blame on all provincial authorities. Had British officials in Britain or North America diminished proprietary authority, as Franklin campaigned for, the popular faction would have been freed to address the needs of the westerners more appropriately and thus may have avoided the civil strife that emerged in the 1760s.

Nor had British authorities adequately addressed the diplomatic situation with neighboring native peoples. By 1758 , with large British forces in Pennsylvania, citizens continued to be victimized by Indian raiders. "The regular Army," wrote William Franklin, "has not been able to secure its Inhabitants from Scalping by the Indians; who coming secretly in very small Parties, skulking in the Woods, must sometimes have it in their Power to surprise and destroy Travellers, or single Families settled in

\footnotetext{
${ }^{731}$ The Pennsylvania Gazette, 25 March 1756.
} 
scattered Plantations ... Centinels posted round an Army, while standing on their Guard, with Arms in their Hands, are often killed and scalped by Indians." ${ }^{732}$ Forbes, who unsuccessfully tried to track down enemy attackers, cannot be faulted for his efforts. The results, however, led to "some complaint of the inhabitants." ${ }^{\prime 733}$ The violence continued through 1765 as a widespread Indian conflict called Pontiac's Uprising erupted in 1763.

When Pontiac's Uprising came to a conclusion, colonists began to trade again with the west in earnest. Initially confined to military contracts for the British garrison at Fort Pitt, wily traders such as George Croghan managed to include items for the Indian trade in his shipments. Settlers in the west were unlikely to view the resumption of the Indian trade favorably, as they had suffered so terribly during the Seven Years' War and more recently during Pontiac's Uprising. In March, the scheme became exposed when "[u]nhappily the head came out of one of the barrels which was full of scalping knives ... the news of this alarmed the upper end of the country ... upon which advertisements were posted up, inviting all to join and prevent the carrying ammunition and such things to the Indians." ${ }^{734}$ Quick to answer the call, James Smith formed the infamous Black Boys-known for painting their faces black and generally portraying themselves as Indians - to oppose the British supply trains.

Although the Black Boys elicited much condemnation from eastern Pennsylvanians, they enjoyed tremendous support in the western counties. As a consequence, the Black Boys refused to honor military trade passes, and instead declared that anyone wishing to transport goods across Pennsylvania must receive local passes. The magistrates in western counties readily supported the demand by producing local documents. British authorities obviously ignored such measures, and continued to provide military passes for contractors supplying garrisons in the west who also continued

732 The Pennsylvania Gazette, 8 December 1757. William Franklin, son of Benjamin Franklin, is here referring to New York under Lord Loudon's command. The results, however, were no different in Pennsylvania.

${ }^{733}$ Peter Bard to Joseph Shippen, 20 July 1758, in Shippen Papers.

${ }^{734}$ Lucier ed., Pontiac's Conspiracy, 279. 
to transport goods for the Indian trade. The Black Boys responded by waylaying a supply convoy in 1765 where, careful not to appear as a lawless mob, they destroyed only what goods they considered contraband. The confrontation then escalated. After a brief skirmish between a British detachment and the Black Boys, several of Smith's men were captured and imprisoned in Fort Loudon. Smith managed to secure the release of his companions after placing the fort under siege. Smith continued to agitate along the Forbes Road, ultimately seizing Fort Bedford in 1769. Although the conflict might have further escalated, British concerns shifted eastward as discontentment emerged in the more significant settlements of the eastern seaboard over taxation policies. ${ }^{735}$

For Smith, however, the events of the 1760 s in the backcountry possessed tremendous significance. Referring to the capture of Fort Bedford much later in life, he claimed "[t]his, I believe was the first British fort in America, that was taken by what they called American rebels." ${ }^{736}$ Smith further claimed "they were Ready for a Rebellion." ${ }^{\text {"37 }}$ Once again, Smith recorded these sentiments after the Revolutionary War and reflect the exuberance of many Americans newly liberated from British imperial rule. At the same time, however, the actions of Smith and his men and the widespread support they received cannot be discounted entirely.

Since 1755, with the arrival of General Braddock and the appointment of William Johnson as Superintendent of Indian Affairs, the British had increasingly attempted to take control of diplomacy with native peoples. Forbes accelerated this goal in 1758 and by the time of the maneuverings of Smith and his men General Amherst had assumed direction of Indian diplomacy. Pennsylvanians, while not necessarily willing to cede complete control of native interactions to the British, had nonetheless cooperated, most notably at the conferences at Easton in 1758. Had the British been more successful in preserving peace with Pennsylvania's neighboring natives, the colonists likely would have welcomed

\footnotetext{
${ }^{735}$ For a detailed description of James Smith's actions, see Dixon, Never Come to Peace, 254-258.

${ }^{736}$ Quoted in Neil Swanson, The First Rebel (New York: Farrar \& Rinehart, 1937), 379-380.

${ }^{737}$ Loudon, Loudon's Indian Narratives, 244-245.
} 
their direction. With the fresh outbreak of violence in 1763 , however, men like Smith came to question the ability of the British to manage such important affairs. The fact that men like Croghan, operating under the umbrella of British authority as deputy Indian agent, attempted to make a personal profit by trading with the Indians while hostilities continued further strained the credibility of the British. Thus, British authorities had taken a broken system - the competitive nature of colonial diplomacy with native peoples - and not only failed to fix it but, from the perspective of some Pennsylvanians, made it worse.

The same might be said to be true of Pennsylvania's dealings with its neighboring colonies. At the outbreak of the Seven Years' War, the province had three major border disputes with Connecticut, Maryland and Virginia. None of them had been resolved by the end of the conflict and only that with Maryland had been decided by the outbreak of the Revolution. That with Virginia burned the hottest, leading to competition and violence between citizens of the two colonies, then states, well into the Revolution in what is now western Pennsylvania. As with native diplomacy, the British had not only failed to resolve these issues but had, inadvertently through the road controversy between Pennsylvania and Virginia, exacerbated them.

Historians have correctly argued that the Seven Years' War resulted in a heightened sense of pride in the British Empire amongst its North American colonists. If they possessed this pride, however, they must have expected tangible benefits from being participants. A close study of Pennsylvania, however, demonstrates that in several critical areas-internal politics, Indian diplomacy and competition with other colonies - the British Empire either failed to resolve issues or worsened them. If colonists questioned their relationship to empire during the 1760s and 1770s, their disappointment with imperial authorities on a local level dated back to the Seven Years' War.

The disappointment went both ways as the plethora of derogatory comments British officers made about colonists demonstrates. Pennsylvanians, almost without exception, desperately wanted the British agents of authority they encountered to care as much about their interests as they did. These 
agents, in turn, expected the colonists to possess a similar commitment to empire that they held. The two entities thus failed to see each other for the interested parties that they were. Pennsylvanians cared about empire, but as an intangible thing. They cared much more deeply about the everyday matters that affected their lives most directly. If the empire could improve their daily lives, they proved entirely supportive. As evidenced by the failure of British agents to effectively do this, the disappointment felt by the colonists proves understandable. This failure, however, should not be attributed to the ineptitude or arrogance of these British agents as suggested by some historians. The British, similar to the colonists, must be viewed from their point of view. As the actions of Forbes demonstrate, those more directly connected to empire did not ultimately care about internal issues in the colonies. They worried much more about imperial concerns and connections, and, many times, how their actions might affect their personal situation. These disparate views and expectations, then, provide a better framework from which to evaluate the diminishment of the Anglo-American relationship in the mid-eighteenth century. The British failed to resolve local disputes which continued on and, in cases such as that of the territorial dispute between Pennsylvania and Virginia, became exacerbated. British agents introduced new debates as well, most significantly the nature of the relationship between colonies and an imperial organization that appeared so disinterested in their most dearly held concerns. 


\section{Works Cited}

\section{Primary Sources}

Anderson, Fred, ed. George Washington Remembers: Reflections on the French \& Indian War. New York: Rowman \& Littlefield Publishers, Inc., 2004.

Benjamin Chew Journal. Historical Society of Pennsylvania, Philadelphia.

Brook, John ed. Horace Walpole: Memoirs of King George II. 3 Vols. New Haven, CT: Yale University Press, 1985.

Chester County Papers, Historical Society of Pennsylvania, Philadelphia.

Conrad Weiser Papers. Historical Society of Pennsylvania, Philadelphia.

Cox-Parrish-Wharton Papers. Historical Society of Pennsylvania, Philadelphia.

Dalhousie Muniments. 1748-1759, Film 389. David Library of the American Revolution, Philadelphia.

Dexter, David \& Franklin B. McClure, eds. Diary of David McClure, Doctor of Divinity, 1748-1820. Knickerbocker Press, 1899.

Dunbar, John R., ed. The Paxton Papers. The Hague, Netherlands: Martinus Nijoff, 1957.

Forbes Papers, Scottish National Archives, Edinburgh.

Friendly Association Minutes, 1755-1757, Historical Society of Pennsylvania, Philadelphia.

Harpster, John W. Crossroads: Descriptions of Pennsylvania, 1720-1829. Pittsburgh: University of Pittsburgh Press, 1938.

Holdernesse Papers, British Library, London.

James, Alfred Proctor, ed. The Writings of General John Forbes: Relating to his Service in North America. Menasha, WI: The Collegiate Press, 1938. 
James Clark Moore Collection, Historical Society of Pennsylvania, Philadelphia.

James Kenny Journal, 1758-1763, Historical Society of Pennsylvania, Philadelphia.

John Jones Jr. Daybook, Historical Society of Pennsylvania, Philadelphia.

Kimball, Gertrude Selwyn ed. Correspondence of William Pitt When Secretary of State with Colonial Governors and Military and Naval Commissioners in America. 2 Vols. New York: Kraus Reprint Co., 1969.

Knight, Lucian Lamar ed. The Colonial Records of Georgia. 26 Vols. Atlanta, GA: Chas P Byrd State Printer, 1916.

Knoblauch, Edward H. ed. The Papers of Sir William Johnson. Digital Edition. 14 Vols. Albany, NY: The New York State Library, 2008.

Loudon, Archibald ed. Loudon's Indian Narratives. Lewisburg, PA: Wennawoods Publishing, 1996.

Lucier, Armand Francis, ed. Pontiac's Conspiracy \& Other Indian Affairs: Notices Abstracted from Colonial Newspapers, 1763-1765. Bowie, MD: Heritage Books, 2000.

Mays, Edith, ed. Amherst Papers: 1756-1763, The Southern Sector: Dispatches from South Carolina, Virginia and His Majesty's Superintendent of Indian Affairs. Westminster, MD: Heritage Books, 1999.

Mordaunt, Sir John. The Proceedings of a General Court-Martial Held in the Council-Chamber at Whitehall. Dublin: Printed for J. Hoey, P. Wilson, J. Exshaw, W. Sleater, and R. Smith, Booksellers, 1758. Accessed in Eighteenth Century Collections Online on March 154, 2010.

McCulloch, Ian and Timothy Todish, eds. Through So Many Dangers: The Memoirs and Adventures of Robert Kirk, Late of the Royal Highland Regiment. Fleishmans, NY: Purple Mountain Press, 2004. Newcastle Papers, British Library, London.

Norris Family Papers, Historical Society of Pennsylvania, Philadelphia.

Papers Relating to North America, 2 Vols., British Library, London.

Pemberton Family/Clifford Correspondence, Historical Society of Pennsylvania, Philadelphia. 
Pemberton Family Papers, Historical Society of Pennsylvania, Philadelphia.

Pemberton Family, Pemberton-Fothergill Correspondence, Historical Society of Pennsylvania, Philadelphia.

Person of Distinction. A Genuine Narrative of the Enterprize Against the Stores and Shipping at St.

Maloes, from the Letters of a Person of Distinction in the Service. London: Printed for J. Staples, 1758. Accessed in Eighteenth Century Collections Online. March 14, 2010.

Reese, George ed., The Official Papers of Frances Fauquier: Lieutenant Governor of Virginia, 1758-1768. 3 Vols. Charlottesville, VA: The University Press of Virginia, 1980.

Roberdeau Buchanan Collection. Historical Society of Pennsylvania, Philadelphia.

Shippen Family Papers. Historical Society of Pennsylvania, Philadelphia.

Stevens, S.K., Donald H. Kent, and Autumn L. Leonard eds. The Papers of Henry Bouquet: The Forbes Expedition. 6 Vols. Harrisburg, PA: The Pennsylvania Historical and Museum Commission, 1951.

Stevens, Sylvester K. and Donald H. Kent, eds. Wilderness Chronicles of Northwestern Pennsylvania. Lewisburg, PA: Wennawoods Publishing, 2002.

Stewart, Irene ed. Letters of General John Forbes: Relating to the Expedition Against Fort Duquesne in 1758. Pittsburgh: Allegheny County Committee, 1927.

The Pennsylvania Gazette. Philadelphia, PA. 1757-1766.

Twaites, Reuben Gold, ed. Early Western Journals: 1748-1765. Lewisburg, PA: Wennawoods Publishing, 1998.

William Pitt Family Papers, 1757-1804. DAR.1925.08, Darlington Collection, Special Collections Department, University of Pittsburgh: Pittsburgh.

William Strahan Letters to David Hall. Historical Society of Pennsylvania, Philadelphia.

\section{Secondary Sources}

Alexander, John K. "Deference in Colonial Pennsylvania and That Man from New Jersey". The 
Pennsylvania Magazine of History and Biography. Vol. 102, No. 4 (October, 1978): 422-436.

Anderson, Fred. Crucible of War: The Seven Years' War and the Fate of Empire in British North America, 1754-1766. New York: Vintage Books, 2000.

Anderson, Niles. "New Light on the Forbes Expedition," The Western Pennsylvania Historical Magazine, Vol. 50, No. 2 (April 1967): 89-103.

Andrews, Charles M. The Colonial Background of the American Revolution. New Haven, CT: Yale University Press, 1924. . The Colonial Period of American History. 3 Vols. New Haven, CT: Yale University Press, 1935.

Bailyn, Bernard. The Ideological Origins of the American Revolution. Cambridge, MA: The Belknap Press of the Harvard University Press, 1967.

Bankhurst, Benjamin. "A Looking-Glass for Presbyterians: Recasting a Prejudice in Late Colonial Pennsylvania". The Pennsylvania Magazine of History and Biography. Vol. 133, No. 4 (October, 2009): 317-348.

Barr, Daniel. A Colony Sprung from Hell: Pittsburgh and the Struggle for Authority on the Western Pennsy/vania Frontier, 1744-1794. Kent, OH: Kent State University Press, 2014. . 'Victory at Kittanning?: Reevaluating the Impact of Armstrong's Raid on the Seven Years' War in Pennsylvania". Pennsylvania Magazine of History and Biography, 141 (January 2007): 141.

Becker, Laura L. "The People and the System Legal in a Colonial Pennsylvania Town". The Pennsylvania Magazine of History and Biography. Vol. 105, No. 2 (April, 1981): 135-149.

Black, Jeremy. Pitt the Elder. New York: Cambridge University Press, 1992.

Boulware, Tyler. Deconstructing the Cherokee Nation: Town, Region, and Nation among EighteenthCentury Cherokees. Gainesville, FL: The University Press of Florida, 2011.

Brewer, John. The Sinews of Power: War, Money, and the English State, 1688-1783. Cambridge, MA: The Harvard University Press, 1990. 
Brodine, Charles. "Civil-Military Relations in Pennsylvania, 1758-1760: An Examination of John Shy's Thesis". Pennsylvania History. Vol. 62, No. 2 (Spring, 1995): 213-233.

Brumwell, Stephen. Paths of Glory: The Life and Death of General Wolfe. Montreal: McGill-Queens University Press, 2006.

Charteris, Even. William Augustus, Duke of Cumberland and the Seven Years' War. London: Hutchinson \& Co., nd.

Colley, Linda. Captives: Britain, Empire, and the World, 1600-1850. New York: Anchor Books, 2002.

Cubbison, Doug. The British Defeat of the French in Pennsylvania, 1758: A Military History of the Forbes Campaign Against Fort Duquesne. Jefferson, NC: McFarland, 2010.

Dixon, David. Never Come to Peace Again: Pontiac's Uprising and the Fate of the British Empire in North America. Norman, OK: University of Oklahoma Press, 2005.

Dorwart, Jeffrey M. Invasion and Insurrection: Security, Defense, and War in the Delaware Valley, 16211815. Newark, DE: University of Delaware Press, 2008.

Fisk Jr., William L. "The Diary of John Cuthbertson, Missionary to the Covenanters of Colonial Pennsylvania." The Pennsylvania Magazine of History and Biography. Vol. 73, No. 4 (Oct. 1949): 441-458.

Florin, John. The Advance of Frontier Settlement in Pennsylvania, 1638-1850: A Geographic Interpretation. University Park, PA: Department of Geography, The Pennsylvania State University, 1977.

Gerber, Scott D. "William Penn and the Origins of Judicial Tenure During Good Behavior". The Pennsylvania Magazine of History and Biography. Vol. CXXXVI, No. 3 (July, 2012): 233-252.

Gipson, Lawrence Henry. The British Empire Before the American Revolution. New York, Knopf Publishing, 1958. . The Great War for the Empire: The Years of Defeat, 1754-1757. $6^{\text {th }}$ Vol. New York: Alfred A. Knopf, Inc., 1946. 
. The Coming of the Revolution: 1763-1775. New York: Harper Torchbooks, 1954.

Green, Walford Davis. William Pitt, Earl of Chatham, and the Growth and Division of the British Empire, 1708-1778. New York: G.P. Putnam's Sons, 1901.

Grenier, John. The First Way of War: American War Making on the Frontier. New York: Cambridge University Press, 2005.

Guenther, Karen. "Rememb'ring our Time and Work is the Lords": The Experiences of Quakers on the Eighteenth-Century Frontier. Sellingsgrove, PA: Susquehanna University Press, 2005.

Häberlein, Mark. “German Migrants in Colonial Pennsylvania: Resources, Opportunities, and Experience". The William and Mary Quarterly. Third Series, Vol. 50, No. 3 (July, 1993): 555-574.

Hackman, W. Kent. "William Pitt and the Generals: Three Case Studies in the Seven Years' War". Albion: A Quarterly Journal Concerned with British Studies. Vol. 3, No. 3 (Autumn, 1971): 128-137. Haffenden, Philip. "Colonial Appointments and Patronage under the duke of Newcastle, 1725-1739". The English Historical Review, Vol. 78, No. 308 (July 1963): 417-435.

Hatley, Tom. The Dividing Paths: Cherokees and South Carolinians through the Revolutionary War Era. New York: Oxford University Press, 1995.

Hershberger, Guy Franklin. "Pacifism and the State in Colonial Pennsylvania". Church History. Vol. 8, No. 1 (March, 1939): 54-74.

Hinderaker, Eric. Elusive Empires: Constructing Colonialism in the Ohio Valley, 1673-1800. New York: Cambridge University Press, 1997.

Hoffstra, Warren R. The Planting of New Virginia: Settlement and Landscape in the Shenandoah Valley. Baltimore: The Johns Hopkins University Press, 2004.

Isaacson, Walter. Benjamin Franklin: An American Life. New York: Simon \& Schuster, 2003. James, Alfred Proctor and Charles Morse Stotz, Drums in the Forest: Decision at the Forks, Defense in the Wilderness. Pittsburgh: Historical Society of Western Pennsylvania, 1958.

Jenson, Arthur L. "The Inspection of Exports in Colonial Pennsylvania". The Pennsy/vania Magazine of 
History and Biography, Vol. 78, No. 3 (July 1954): 275-297.

Johnson, Daniel. “'What Must Poor People Do?': Economic Protest and Plebeian Culture in Philadelphia, 1682-1754". Pennsylvania History: A Journal of Mid-Atlantic Studies. Vol. 79, No. 2 (Spring 2012): 117-153.

Keller, Clair W. "The Rise of Representation: Electing County Officeholders in Colonial Pennsylvania". Social Science History. Vol. 3, No. 3/4 (1979): 139-166.

Kennedy, Michael V. "'Cash for Turnips': Agricultural Production for Local Markets in Colonial Pennsylvania, 1725-1783". Agricultural History. Vol. 74, No. 3 (Summer, 2000): 587-608.

Kenny, Kevin. Peaceable Kingdom Lost: The Paxton Boys and the Destruction of William Penn's Holy Experiment. New York: Oxford University Press, 2009.

Klingberg, Frank J. "The Anglican Minority in Colonial Pennsylvania, with Particular Reference to the Indian". The Pennsylvania Magazine of History and Biography, Vol. 65, No. 3 (July 1941): 276299.

Knight, Carol Lynn H. “A Certain Great Commoner: The Political Image of William Pitt, First Earl of Chatham, in the Colonial Press". Proceedings of the American Philosophical Society. Vol. 123, No. 2 (Apr. 27, 1979): 131-142.

Knight, Carol Lynn Homelsky. The Political Image of William Pitt, First Earl of Chatham, in the American Colonial Press, 1756-1778. Unpublished PhD Dissertation: The College of William and Mary, 1973.

Knollenberg, Bernhard. Origin of the American Revolution: 1759-1766. Indianapolis: Liberty Fund, 1960.

Knouff, Gregory T. The Soldier's Revolution: Pennsylvanians in Arms and the Forging of American Identity. University Park, PA: The Pennsylvania State University Press, 2004.

Langford, Paul. "Pitt and Public Opnion, 1757". The English Historical Review. Vol. 88, No. 346 (January, 1973): 54-80.

Leach, Douglas Edward. Roots of Conflict: British Armed Forces and Colonial Americans, 1677-1763. 
Chapel Hill, NC: The University of North Carolina Press, 1986.

Lengel, Edward G. General George Washington: A Military Life. New York: Random House, 2005.

Leonard, Joan de Lourdes. "Elections in Colonial Pennsylvania". The William and Mary Quarterly. Third Series, Vol. 11, No. 3 (July 1954): 385-401.

Lewis, Thomas A. For King and Country: George Washington the Early Years. New York: John Wiley \& Sons, 1993.

Lucas, Reginald. George II and His Ministers. London: Arthur L. Humphrey's, 1910.

Marshall, P.J. The Making and Unmaking of Empires: Britain, India, and America, c. 1750-1783. New York: Oxford University Press, 2005.

McConnell, Michael. A Country Between: The Upper Ohio Valley and Its Peoples, 1724-1774. Lincoln, NE: University of Nebraska Press, 1992.

McCoy, Michael B. “Barbarian Philosophe: Market, Modernity, and the Enlightenment on James Smith's Frontier". Pennsylvania History. Vol. 76. No.3 (Summer, 2009): 217-249.

Merrell, James H. Into the American Woods: Negotiators on the Pennsylvania Frontier. New York: W.W. Norton \& Company, 1999.

Middleton, Richard. The Bells of Victory: The Pitt-Newcastle Ministry and the Conduct of the Seven Years' War, 1757-1762. New York: Cambridge University Press, 1985.

Montgomery, Thomas Lynch, ed. Report of the Commission to Locate the Site of the Frontier Forts of Pennsylvania. 2 Vols. Harrisburg, PA: WM Stanley Ray, State Printer, 1916.

Murphey, Andrew R. Conscience and Community: Revisiting Toleration and Religious Dissent in Early Modern England and America. University Park, PA: The Pennsylvania State University Press, 2001.

Newland, Samuel J. The Pennsylania Militia: The Early Years, 1669-1792. Annville, PA: Commonwealth of Pennsylvania Department of Military and Veterans Affairs, 1997.

Oliphant, John. Peace and War on the Anglo-Cherokee Frontier, 1756-1763. Baton Rouge, LA: Louisiana 234 
State University Press, 2001.

Olsen, Alison Gilbert. Making the Empire Work: London and American Interest Groups, 1690-1790.

Cambridge, MA: The Harvard University Press, 1992.

Peters, Marie. Pitt and Popularity: The Patriot Minister and London Opinion during the Seven Years' War. Oxford: Clarendon Press, 1980.

Preston, David L. “"Make Indians of our White Men": British Soldiers and Indian Warriors from Braddock's to Forbes's Campaigns, 1755-1758." Pennsylvania History. Vol. 74, No. 3 (Summer 2007): 280-306.

Richter, Daniel K. Facing East From Indian Country: A Native History of Early America. Cambridge, MA: Harvard University Press, 2001.

Russell, Marvin F. "Thomas Barton and Pennsylvania's Colonial Frontier". Pennsylvania History. Vol. 46, No. 4 (October 1979): 312-334.

Schwartz, Sally. "A Mixed Multitude": The Struggle for Toleration in Colonial Pennsylvania. New York: New York University Press, 1987.

. "William Penn and Toleration: Foundations of Colonial Pennsylvania". Pennsylvania History. Vol. 50, No. 4 (October, 1983): 284-312.

Schweitzer, Mark McKinney. "Contracts and Custom: Economic Policy in Colonial Pennsylvania". The Journal of Economic History. Vol. 45, No. 2 (June, 1985): 463-465.

Schweizer, Karl W. "William Pitt, Lord Bute, and the Peace Negotiations with France, May-September 1761". Albion: A Quarterly Journal Concerned with British Studies. Vol. 13, No. 3 (Autumn, 1981): 262-275.

Sherrard, O.A. Lord Chatham: Pitt and the Seven Years' War. London: The Garden City Press Limited, 1955.

Shy, John. A People Numerous and Armed: Reflections on the Military Struggle for American Independence. Ann Arbor, MI: The University of Michigan Press, 1990. 
Silver, Peter. Our Savage Neighbors: How Indian War Transformed Early America. New York: W.W. Norton \& Company, 2008.

Simler, Lucy. "Tenancy in Colonial Pennsylvania: The Case of Chester County." The William and Mary Quarterly. Third Series, Vol. 43, No. 4 (October 1986): 542-569.

Stern, Mark Abbott. David Franks: Colonial Merchant. University Park, PA: The Pennsylvania State University Press, 2010.

Stephenson, R.S. "Pennsylvania Provincial Soldiers in the Seven Years' War". Pennsylvania History. Vol. 62, No. 2 (Spring, 1995): 196-212.

Stotz, Charles Morse. "Forbes Conquers the Wilderness: A Modern Odyssey". The Western Pennsylvania Historical Magazine. Vol. 67, No. 4 (October, 1984): 309-322.

Strang, Cameron B. "The Mason-Dixon and Proclamation Lines: Land Surveying and Native Americans in Pennsylvania's Borderlands". The Pennsylvania Magazine of History and Biography. Vol. CXXXVI, No. 1 (January, 2012): 5-24.

Sutto, Antoinette. "The Borders of Absolutism: William Penn, Charles Calvert, and the Limits of Royal Authority, 1680-1685. Vol. 76, No. 3 (Summer 2009): 276-300.

Swanson, Neil. The First Rebel. New York: Farrar \& Rinehart, 1937.

Tiedeman, Joseph S. "Interconnected Communities: The Middle Colonies on the Eve of the American Revolution." Pennsylvania History. 76 (Winter 2009): 1-29.

Treese, Lorett. The Storm Gathering: The Penn Family and the American Revolution. Mechanicsburg, PA: Stackpole Books, 2002.

Tully, Alan. "Englishmen and Germans: National-Group Contact in Colonial Pennsylvania, 1700-1755". Pennsylvania History. Vol. 45, No. 3 (July, 1978): 237-256.

Waddell, Louis M. “Defending the Long Perimeter: Forts on the Pennsylvania, Maryland, and Virginia Frontier: 1758-1765". Pennsylvania History. Vol. 62, No. 2 (Spring, 1995): 171-198. Wallace, Paul A.W. Indian Paths of Pennsylvania. Harrisburg, PA: Pennsylvania Historic and Museum 236 
Commission, 1965.

Ward, Mathew C. "An Army of Servants: The Pennsylvania Regiment During the Seven Years' War," The Pennsy/vania Magazine of History and Biography, Vol. 119, No. $1 / 2$ (JanuaryApril 1995): 75-93. . Breaking the Backcountry: The Seven Years' War in Virginia and Pennsylvania, 17541765. Pittsburgh: University of Pittsburgh Press, 2003. . "La Guerre Sauvage": The Seven Years' War on the Virginia and Pennsy/vania Frontier. Unpublished PhD Dissertaton: College of William and Mary, 1992. - "The Peaceable Kingdom Destroyed: The Seven Years' War and the Transformation of the Pennsylvania Backcountry." Pennsylvarynia History. 74 (Summer 2007): 247-279.

Wellenreuther, Hermann. "The Quest for Harmony in a Turbulent World: The Principle of "Love and Unity" in Colonial Pennsylvania Politics". The Pennsylvania Magazine of History and Biography. Vol. 107, No. 4 (October 1983): 537-576.

Wendel, Thomas. "The Keith-Lloyd Alliance: Factional and Coalitin Politics in Colonial Pennsylvania". The Pennsylvania Magazine of History and Biography. Vol. 92, No. 3 (July 1968): 289-305.

White, Richard. The Middle Ground: Indians, Empires, and Republics in the Great Lakes Region, 16501815. New York: Cambridge University Press, 1991.

Williams, Basil. The Life of William Pitt, Earl of Chatham. New York: Octagon Books, Inc., 1966. . The Oxford History of England: The Whig Supremacy, 1714-1760. $2^{\text {nd }}$ Edition revised by C.H. Stuart. Oxford: The Clarendon Press, 1997.

Yewlett, Hilary Lloyd. "Early Modern Migration from the Mid-Wales County of Radnorshire to Southeastern Pennsylvania, with Special Reference to Three Meredith Families". Pennsylvania History: A Journal of Mid-Atlantic Studies. Vol. 79, No. 1 (Winter, 2012): 1-32.

\section{General Reference Works}

Oxford Dictionary of National Biography. 
